\title{
Logística e Gestão da Cadeia de Suprimentos na Área Portuária
}

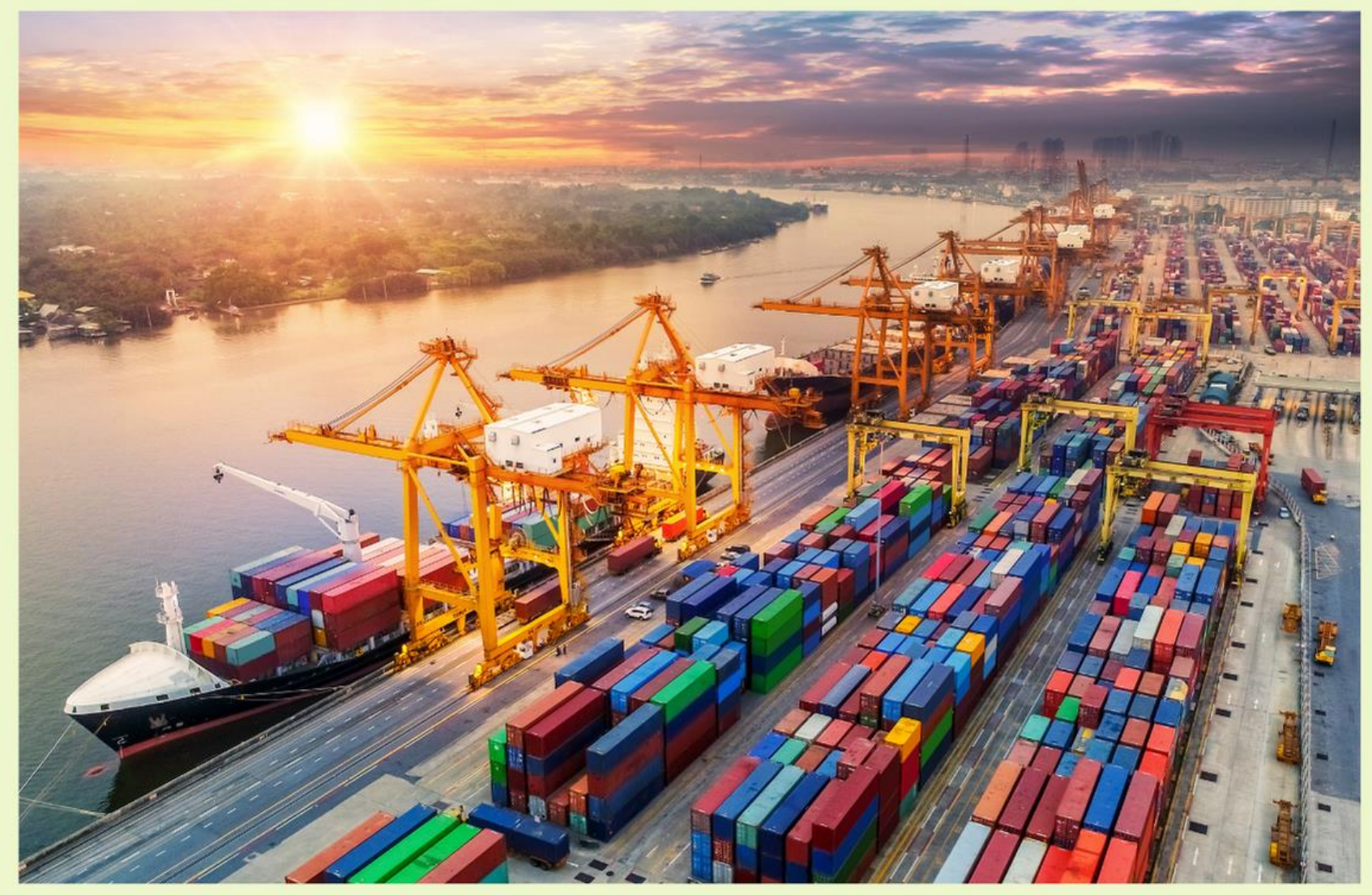

\section{Organizador}

Alexandre Ricardo Machado

Julio Cesar Raymundo

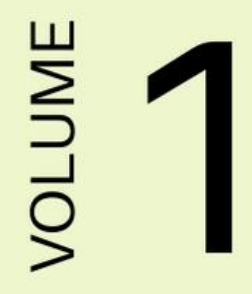

Editora Poisson

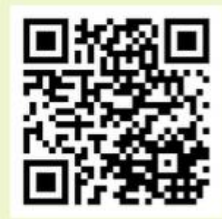


Alexandre Ricardo Machado

Julio Cesar Raymundo

(Organizadores)

\section{Logística e Gestão da Cadeia de Suprimentos na Área Portuária Volume 1}

1a Edição

Belo Horizonte

Poisson

2022 


\section{Editor Chefe: Dr. Darly Fernando Andrade}

\section{Conselho Editorial}

Dr. Antônio Artur de Souza - Universidade Federal de Minas Gerais

Ms. Davilson Eduardo Andrade

Dra. Elizângela de Jesus Oliveira - Universidade Federal do Amazonas

Msc. Fabiane dos Santos

Dr. José Eduardo Ferreira Lopes - Universidade Federal de Uberlândia

Dr. Otaviano Francisco Neves - Pontifícia Universidade Católica de Minas Gerais

Dr. Luiz Cláudio de Lima - Universidade FUMEC

Dr. Nelson Ferreira Filho - Faculdades Kennedy

Ms. Valdiney Alves de Oliveira - Universidade Federal de Uberlândia

Dados Internacionais de Catalogação na Publicação (CIP)

L832
Logística e Gestão da Cadeia de Suprimentos na Área
Portuária - Volume 1/ Organização: Alexandre
Ricardo Machado; Julio Cesar Raymundo - Belo
Horizonte - MG: Poisson, 2022
Formato: PDF
ISBN: 978-65-5866-142-9
DOI: 10.36229/978-65-5866-142-9
Modo de acesso: World Wide Web
Inclui bibliografia
1. Logística 2. Gestão. 3. Área Portuária
I. MACHADO, Alexandre Ricardo II. RAYMUNDO, Julio
Cesar III. Título
podendo ser utilizado para fins comerciais e nem ser alterada.

O conteúdo dos artigos e seus dados em sua forma, correção e confiabilidade são de responsabilidade exclusiva dos seus respectivos autores

www.poisson.com.br contato@poisson.com.br 


\section{Organizadores}

Alexandre Ricardo Machado

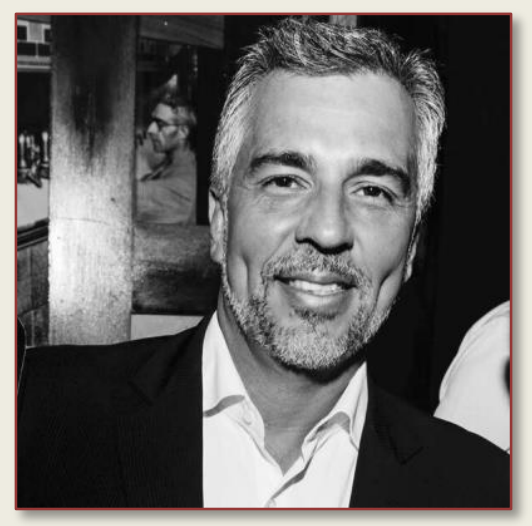

É Doutor em Direito Ambiental Internacional e Mestre em Direito Ambiental pela Universidade Católica de Santos (UNISANTOS/SP), possui Especialização em Direito do Petróleo e Gás (FGV/RJ) e Didática do Ensino Superior (UNIMONTE/SP). É Professor de Terminais Offshore, Transporte Marítimo e Projeto Integrador na Faculdade Estadual de Tecnologia da Baixada Santista (FATEC Rubens Lara/SP). É Professor Convidado da PósGraduação em Direito Marítimo e Portuário e Direito do Trabalho na Universidade Católica de Santos (UNISANTOS/SP). Possui Graduação em Administração de Empresas (EAESP/SP), Ciências Sociais e Jurídicas e Pedagogia (UNIMES/SP). É Consultor e Advogado (Brasil/Portugal). Tem experiência na área do Direito Energético e Ambiental, atuando principalmente em planejamento ambiental estratégico, licitações e gestão de contratos em infraestrutura. Interesses de pesquisa: Energia e Meio Ambiente; Terminais Offshore e Gestão Portuária com ênfase em Logística no Transporte Marítimo; Comércio Internacional e Revolução 4.0; Sustentabilidade e Mudanças Climáticas.

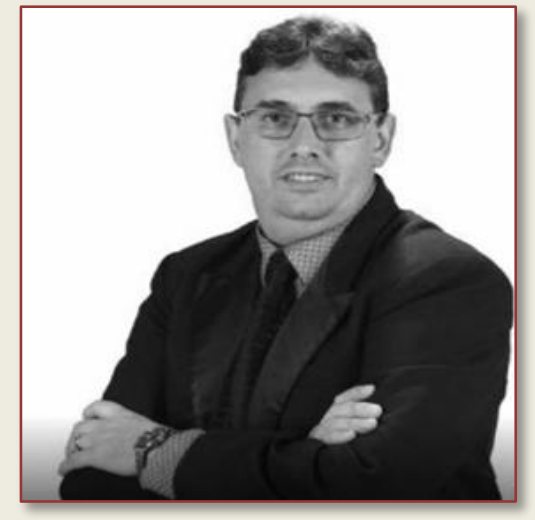

Doutor e Mestre em Engenharia de Produção. Bacharel em Direito e Administração. Professor universitário e consultor de diversas empresas no cenário nacional. Responsável pela criação e coordenação do Curso de Gestão Portuária - da Fatec Baixada Santista Rubens Lara - Centro Paula Souza. No CPS atua na coordenação de projetos pelo Programa Minha Chance. 


\section{SUMÁRIO}

Capítulo 1: A carne bovina e o modal ferroviário no Porto de Santos: Sustentabilidade econômica como alternativa na exportação. 07

Leonardo Ruthes Rego, Luan Helder Santos Moreira, Michelle Teixeira de Lima

DOI: $10.36229 / 978-65-5866-142-9 . C A P .01$

Capítulo 2: Cargas especiais: A problemática do transporte de cargas vivas 18

Fábio Aparecido Ruiz Junior, Luccas Moura Jugo Ramos da Conceição, Viviane Marques Felix

DOI: 10.36229/978-65-5866-142-9.CAP.02

Capítulo 3: Indicadores de desempenho e os respectivos resultados na exportação de celulose através do Porto de Santos 25

Tiago Silva Santa Rosa

DOI: 10.36229/978-65-5866-142-9.CAP.03

Capítulo 4: Exportações de algodão via Porto de Santos

Eduardo Santos do Nascimento, Sarah Silva de Oliveira

DOI: $10.36229 / 978-65-5866-142-9 . C A P .04$

Capítulo 5: Segurança do trabalho na movimentação de carga a granel no Porto de Santos.

Elizandra Paula do Valle Paula, Gabriel da Silva Sousa

DOI: 10.36229/978-65-5866-142-9.CAP.05

Capítulo 6: A matriz ferroviária e o impacto no transporte de cargas pelo Porto de Santos 56

Amanda Gabriela dos Santos Castilho, Gustavo Silva dos Santos

DOI: 10.36229/978-65-5866-142-9.CAP.06

Capítulo 7: Transporte de carga perigosa: Nitrato de amônia 70

Daniel de Carvalho, Guilherme Tavares Gama, Jessica Motta Gonçalves Henrique DOI: 10.36229/978-65-5866-142-9.CAP.07

Capítulo 8: Sistema agroindustrial citrícola: Exportação do suco de laranja. 81 André Martins dos Santos, Giovanni Tirelli Martins Rodrigues DOI: 10.36229/978-65-5866-142-9.CAP.08

Capítulo 9: Cargas especiais: Estudo do transporte de cargas congeladas no Brasil . 92 Danilo Germano Santos, Josué Elias de Souza Júnior, Lucas Fernando de Oliveira Fonseca DOI: 10.36229/978-65-5866-142-9.CAP.09 


\section{SUMÁRIO}

Capítulo 10: Operação no Porto do Açu: Exportação de petróleo. 107

Mário Amorim, Kauany Silva, Daniela Carvalho, Matheus Ferreira

DOI: 10.36229/978-65-5866-142-9.CAP.10

Capítulo 11: Cargas especiais: As peculiaridades no armazenamento e transporte de cargas perigosas - enxofre

Danilo Germano Santos, Raphael Cesar de Brito Aguiar

DoI: 10.36229/978-65-5866-142-9.CAP.11

Capítulo 12: Aplicações do machine learning: Seu uso como ferramenta de otimização portuária 130

Victoria Marques Riechelmann, Vinicios Santos da Silva

DOI: 10.36229/978-65-5866-142-9.CAP.12

Capítulo 13: Cargas indivisíveis da matriz eólica no desenvolvimento da região nordeste do Brasil. 139

Danyel Santiago Santos Dirk, Sidney Evangelista Araujo, José Carlos Santos Santana

DOI: 10.36229/978-65-5866-142-9.CAP.13

Capítulo 14: A importação da soda cáustica dentro do Porto de Santos e os riscos da sua movimentação. 150

Ariane de Lima Monteiro, Marcos Pissarra Bahia

DOI: 10.36229/978-65-5866-142-9.CAP.14

Capítulo 15: Panorama temporal da exportação brasileira de sucata metálica ferrosa 165

Rafael Chaves Osidacz, Danilo Soares Leitão, Rafael de Sousa Oliveira

DoI: 10.36229/978-65-5866-142-9.CAP.15

Capítulo 16: Logística 4.0 e sustentabilidade: Um novo conceito entre o meio ambiente e a tecnologia no porto... 174

Elyza Gomes Rebolo, Josué Elias de Souza Junior

DOI: 10.36229/978-65-5866-142-9.CAP.16 


\section{Capítulo 1}

A carne bovina e o modal ferroviário no Porto de Santos: Sustentabilidade econômica como alternativa na exportação

\section{Leonardo Ruthes Rego}

\section{Luan Helder Santos Moreira}

Michelle Teixeira de Lima

Resumo: Ligada ao setor primário da economia, a agropecuária é uma atividade de suma importância para o mercado brasileiro interno, sendo responsável pelo abastecimento da população, porém, no mercado externo, a agricultura tem uma importante participação, principalmente na exportação de soja, café e carnes. 0 presente trabalho tem como objetivo, descrever a cadeia produtiva da carne bovina destinada à exportação, analisar a logística empregada através do modal rodoviário, apresentando a ferrovia como modal alternativo, e preferível por conta de ser uma opção mais econômica e sustentável. Para isso, foi escolhida a região Centro-Oeste como a principal fornecedora da matéria-prima, e o complexo de Rondonópolis como centro de distribuição para o porto de Santos. Utilizaram-se para a construção deste artigo os métodos de revisão bibliográfica, dados de sites do governo e instituições ligadas ao agronegócio e transportes.

Palavras-chave: Carne bovina. Rodovia. Ferrovia. Economia. Sustentabilidade. 


\section{INTRODUÇÃO}

O setor agropecuário vem se destacando na economia brasileira nas últimas décadas por seu expressivo aumento em produtividade e sua crescente importância para a manutenção do equilíbrio da balança comercial do país (Gasques et al., 2010). 0 Brasil de acordo com a USDA (2009) é considerado o maior produtor e fornecedor do agronegócio de alimentos para os mercados internacionais, se tornando referência quando o assunto é produção e exportação de carne bovina, vendendo carne in natura para 151 países e industrializada para 103 países. Segundo a ABIEC (2020) atualmente, o Brasil produz 10 milhões de toneladas de carne bovina, e 20,8\% são negociados para dezenas de países em todo o mundo.

A necessidade de reduzir os valores e se ajustar a nova demanda por projetos ligados a sustentabilidade no processos e serviços, fez com que as empresas repensassem seu modo de produzir e distribuir.

No ramo do comércio exterior, com foco de exportação de carnes, que é tema deste artigo, é de extrema importância que as empresas brasileiras se adaptem as novas exigências do mercado internacional para que não percam o seu posto como principais fornecedores do commodity. Por conseguinte, o presente estudo este estudo tem como objetivo analisar o processo logístico de transporte multimodal da carne bovina de sua origem (frigorifico) até o seu destino interno (porto de santos) e apresentar uma alternativa viável ao transporte rodoviário nas operações de carne bovina no porto de Santos através da utilização do complexo de Rondonópolis, na região centro oeste, como principal via para escoamento da carne. Tem-se como objetivo especifico delinear a cadeia produtiva da carne bovina destinada à exportação, descrever a logística empregada através do modal rodoviário, apresentando a ferrovia como modal alternativo, e preferível por conta de ser uma opção mais econômica e sustentável.

A pesquisa, ao apresentar as possíveis reduções de custos em um modal diferente do rodoviário, mostrará também que tal mudança acarretará também na redução de caminhões nas estradas, o que reduzirá a emissão de gases poluentes na atmosfera. Espera-se atrair a atenção ao tema e contribuir para novas alternativas de transporte dos principais fornecedores de carne para o porto e que a pesquisa possa servir de base para o transporte de outras matérias primas da região centro oeste para o litoral paulista.

A pesquisa foi realizada em caráter exploratório, que, seguindo a definição de Gerhardt e Silveira (2009), tem como objetivo proporcionar maior familiaridade com o problema estudado, tornando-o mais explícito, levando em consideração o atual cenário brasileiro em relação a cadeira produtiva da carne, com foco no impacto positivo e sustentável da multimodalidade, tendo a ferrovia como principal modal no transporte deste tipo de mercadoria em específico. Sobre a metodologia de revisão bibliográfica, que, também seguindo a definição apresentada por Gerhardt e Silveira (2009), expõe resumidamente as ideias principais discutidas por outros autores que trataram do tema, foi concretizada através de levantamentos de materiais com dados já analisados e publicados por meios escritos e/ou eletrônicos (livros, artigos científicos, páginas na web), construindo-se assim a fundamentação necessária para a justificativa do tema apresentado neste artigo. 


\section{FUNDAMENTAÇÃO TEÓRICA OU REVISÃO DA LITERATURA}

\subsection{CULTIVO DA CARNE BOVINA NO BRASIL}

Segundo o relatório da Associação Brasileira das Indústrias Exportadoras de Carne (2020), as atividades pecuárias representaram 8,5\% do PIB brasileiro em 2019, que foi de $\mathrm{R} \$ 7,3$ trilhões, 6,8\% maior que em 2018, se considerarmos apenas o valor do PIB das atividades pecuárias no Brasil, teremos um valor de $\mathrm{R} \$ 618,50$ bilhões em 2019, 3,5\% acima do valor atingido em 2018 que foi de $\mathrm{R} \$ 597,22$ bilhões, esses dados demonstram a importância deste setor na economia do país.

De acordo com a ABIEC (2020), e que pode ser visto na Tabela 1, o Brasil é atualmente o país número 1 em exportações de proteínas de origem animal, tendo exportado 2.490.300 TEC (Toneladas Equivalentes a Carcaça) em 2019, este volume de exportações equivalem a 23,67\% de toda a produção nacional. 0 segundo maior exportador de proteína de origem animal é a Austrália, com 1.560.600 TEC que representam $69,06 \%$ da produção do país. Se compararmos os dois maiores exportadores do mundo, podemos perceber a soberania brasileira no cenário mundial, o Brasil exporta menos de $1 / 4$ da produção nacional enquanto a Austrália exporta quase $70 \%$ de toda a sua produção, mesmo assim o Brasil conseguiu exportar 929.700 toneladas a mais que a Austrália no ano de 2019.

TABELA 1 - Maiores exportadores de carne bovina em 2019

\begin{tabular}{|l|c|c|c|}
\hline \multicolumn{1}{|c|}{ PAís } & $\begin{array}{c}\text { EXPORTAÇ̃ES } \\
\text { (MIL TEC)* }\end{array}$ & $\begin{array}{c}\text { EXPORTAÇÃO/PRODUÇÃo } \\
(\%)\end{array}$ & $\begin{array}{c}\text { PRODUÇÃo } \\
\text { (MIL TEC) }\end{array}$ \\
\hline Brasil & $2.490,3$ & $23,67 \%$ & $10.491,5$ \\
\hline Austrália & $1.560,6$ & $69,06 \%$ & $2.259,8$ \\
\hline EUA & $1.314,1$ & $10,72 \%$ & $12.255,9$ \\
\hline India & $1.143,2$ & $39,33 \%$ & $2.906,8$ \\
\hline Argentina & 757,3 & $25,16 \%$ & $3.010,1$ \\
\hline Países Baixos & 649,6 & $171,52 \%$ & 378,7 \\
Irlanda & 635,0 & $122,79 \%$ & 517,1 \\
\hline Polônia & 615,7 & $159,65 \%$ & 385,6 \\
\hline Nova Zelândia & 613,8 & $88,45 \%$ & 693,9 \\
\hline Canadá & 516,4 & $38,84 \%$ & $1.329,6$ \\
\hline Alemanha & 461,1 & $41,34 \%$ & $1.115,5$ \\
\hline Outros & $3.497,2$ & $9,87 \%$ & $35.439,3$ \\
\hline Mundo & $14.246,9$ & $20,13 \%$ & $70.784,0$ \\
\hline União Europeia & $3.917,1$ & $53,33 \%$ & $7.344,5$ \\
\hline
\end{tabular}

Fonte: Sumário Beef Report 2020, ABIEC (2020)

Além de ser o principal exportador de proteína animal no mundo o Brasil é também o maior produtor de carne animal, segundo o Sumário Beef Report da ABIEC (2020) o Brasil possui 162,53 milhões de hectares de pasto com taxa de ocupação média de 1,31 cabeça por hectare e 213,68 milhões de cabeças de gado, deste total o país exporta cerca 535.254 animais vivos e abate 43,3 milhões de cabeças ao ano.

\subsection{PRINCIPAIS FORNECEDORES BRASILEIROS}

Segundo o Anuário da revista ISTOÉ Dinheiro (2020) existem 10 empresas do ramo de proteína animal entre as 1.000 maiores empresas do país em faturamento com base no exercício de 2019, o último publicado, sendo que duas delas, JBS S/A e Marfrig Global 
Foods aparecem entre as 20 maiores empresas do país em faturamento, ocupando respectivamente o $2^{\circ}$ e o $18^{\circ}$ lugar, as próximas empresas mais bem colocadas do setor são a BRF Alimentos ocupando o 26을 Lugar e a Minerva Foods ocupando o 58o lugar, a Aurora Alimentos é a última entre as 100 maiores do país ocupando o 91o lugar.

Na tabela 2 é possível observar com clareza os principais fornecedores de proteína animal do país classificados pelo faturamento em 2019, é também possível observar o lucro líquido no período e o valor de seu patrimônio, com base nesses dados podemos criar uma projeção dos valores movimentados pelo mercado.

TABELA 2 - Principais fornecedores brasileiros

\begin{tabular}{|c|c|c|c|c|}
\hline & EMPRESA & $\begin{array}{c}\text { FATURAMENTO } \\
\text { EM MILHÕES }\end{array}$ & $\begin{array}{l}\text { LUCRO } \\
\text { LÍQUIDO }\end{array}$ & $\begin{array}{l}\text { PATRIMÔNIO } \\
\text { LÍQUIDO }\end{array}$ \\
\hline 1 & JBS S/A & $204.523,6$ & $6.464,9$ & $32.482,0$ \\
\hline 2 & MARFRIG GLOBAL FOODS & $48.761,1$ & $1.582,2$ & $1.776,3$ \\
\hline 3 & BRF ALIMENTOS & $33.447,0$ & $1.213,3$ & $8.148,3$ \\
\hline 4 & MINERVA FOODS & $17.122,8$ & 16,2 & $-281,7$ \\
\hline 5 & AURORA ALIMENTOS & $9.920,8$ & 543,3 & $2.214,1$ \\
\hline 6 & LAR COOPERATIVA & $6.695,8$ & 229,1 & $1.648,9$ \\
\hline 7 & COOPAVEL & $2.658,90$ & 82,5 & 366 \\
\hline 8 & ALIBEM ALIMENTOS & $1.502,80$ & 356,9 & 604,2 \\
\hline 9 & PAMPLONA ALIMENTOS & $1.216,10$ & 68,6 & 342,1 \\
\hline 10 & BARRA MANSA ALIMENTOS & 986,2 & 43,8 & 106,6 \\
\hline
\end{tabular}

Fonte: Anuário As 1.000 Maiores da ISTOÉ Dinheiro (2020)

\subsection{CENTRO-OESTE E SUA CADEIA PRODUTIVA BOVINA}

De acordo com a ABIEC (2020), o número de fábricas de empresas associadas entre os estados de Goiás, Mato Grosso, Mato Grosso do Sul, Rondônia e Tocantins, ou seja, estados que podem alimentar um projeto intermodal com levante ferroviário em Rondonópolis-MT, é de 74 unidades, sendo 27 delas no estado do Mato Grosso divididas entre 8 empresas, 16 no Mato Grosso do Sul pertencentes à 7 empresas diferentes, 12 em Goiás divididas entre 7 empresas, 12 em Rondônia dividas entre 6 empresas e 7 no Tocantins também divididas entre 7 empresas diferentes.

No Brasil existem, segundo a ABIEC (2020), e que podem ser observadas na figura 1, cerca de 145 plantas produtivas de abate animal divididas entre 32 empresas diferentes, com base neste dado, pode-se afirmar que a macrorregião de Rondonópolis-MT, corresponde a aproximadamente $51,03 \%$ da produção de proteína animal do país, mais da metade de toda a produção brasileira, sendo assim uma região estratégica para a introdução de um levante rodoviário, visando a otimização financeira do processo de exportação, bem como a diminuição da frota de veículos nas rodovias e consequentemente a diminuição da emissão de gases poluentes nas atmosfera. 


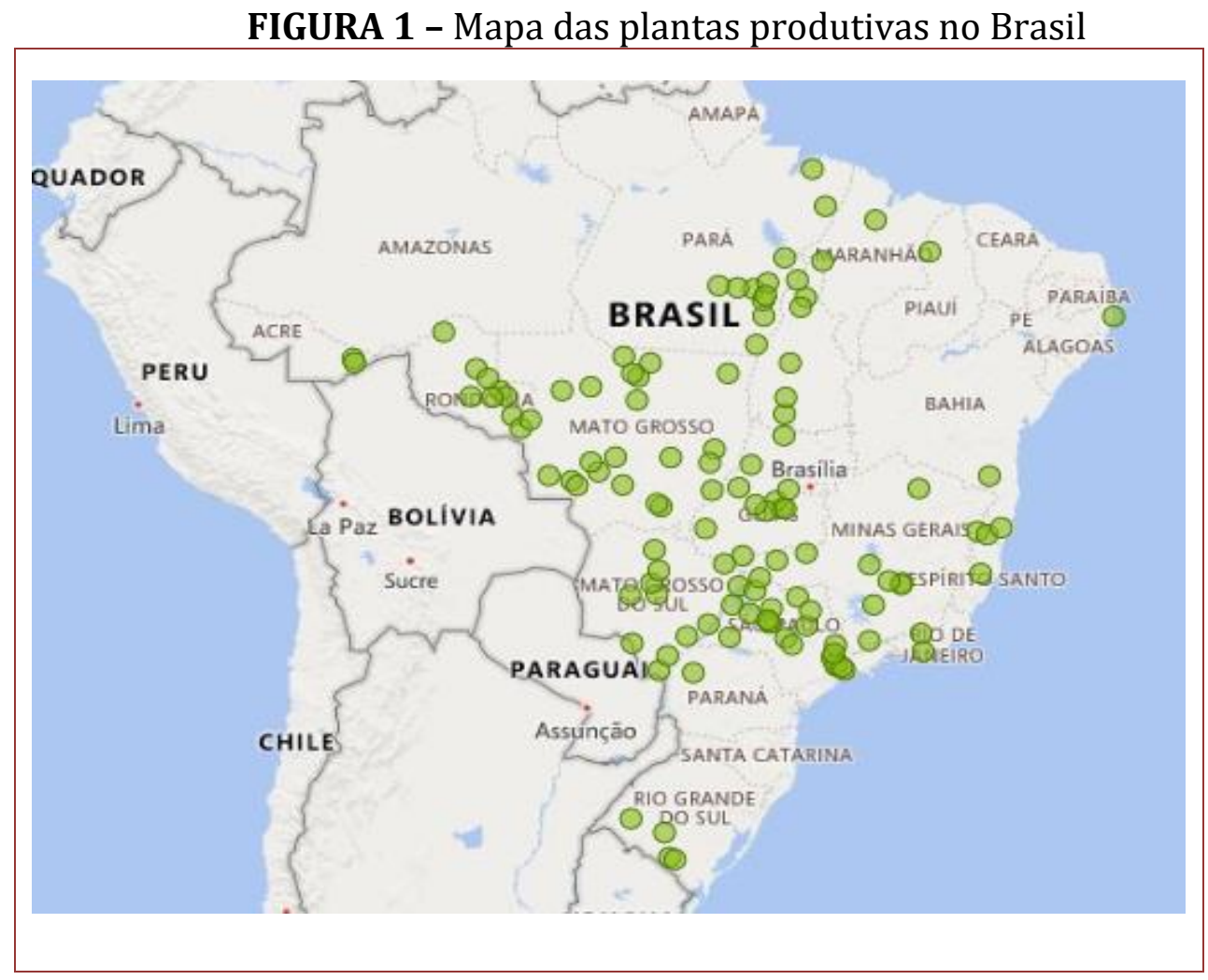

Fonte: Mapa das plantas - ABIEC (2020)

\subsection{LOGÍSTICA DE ESCOAMENTO DE EXPORTAÇÃO ATRAVÉS DO MODAL RODOVIÁRIO}

De acordo com Keedi (2014), o transporte rodoviário é responsável por 61\% da matriz modal brasileira, é ele quem escoa boa parte da produção nacional de commodities, ligando mercados internos, polos industriais, portos e pontos de interesse. Apesar de ser o mais utilizado no Brasil, o modal rodoviário não é o mais eficiente, segundo Rodrigues (2014) a capacidade de carga útil neste modal varia entre 23 e 48 toneladas, o que é relativamente pouco se comparado à outros modais capazes de fazerem carregamentos de grandes quantidades, outros pontos negativos são a incapacidade de percorrer grandes distâncias, a dependência de boas rodovias e de condições de trânsito adequadas, o custo operacional elevado que resulta em um altíssimo valor de frete por quilômetro rodado e a alta emissão de gases poluentes decorrentes do uso de combustível fóssil.

Além de todos os problemas supracitados inerentes ao transporte rodoviário, segundo o Ministério da Infraestrutura (2018), temos aproximadamente 10,3 mil quilômetros de rodovias e estradas não pavimentadas, e 9,7 mil quilômetros de rodovias concedidas à iniciativa privada, isso demonstra uma outra fragilidade deste modal, que é a falta de infraestrutura de estradas de rodagem no Brasil, segundo a Confederação Nacional do Transporte (2018) a malha rodoviária vem sofrendo reduções ano após ano se levados em consideração o número total de quilômetros, apesar de notarmos nos relatórios um cenário de melhora nas condições das vias pavimentadas, isso se deve principalmente às obras de duplicação, extensão de faixas e pavimentação de vias já existentes. 


\subsection{IMPACTOS AMBIENTAIS DA UTILIZAÇÃO DO TRANSPORTE RODOVIÁRIO COMO PRINCIPAL MODAL PARA ESCOAMENTO DA CARNE}

0 transporte realizado por veículos à combustão é predominante nos deslocamentos cotidianos, tanto de pessoas como de cargas, respondendo por grande parte das emissões de poluentes. A queima dos combustíveis fósseis lança grande quantidade de gás carbônico na atmosfera.

Segundo Carvalho (2011), a poluição veicular afeta o meio ambiente de forma abrangente e pode ser classificada em várias categorias. Além dos danos causados próximos aos veículos, de curto alcance, como os ruídos e a fuligem lançada, há também os danos que se deslocam pelas correntes de ar, ocasionados pela emissão de gases, podendo resultar em chuva ácida ou no efeito smòge - " formação de uma névoa densa devido à grande concentração de ozônio (03) no ar". Por último, existem os poluentes globais, gases que afetam todo o planeta por serem a causa do efeito estufa (GEE), sendo o dióxido de carbono (CO2) representante principal da categoria.

0 setor de transporte é responsável por $25 \%$ das emissões globais de gases do efeito estufa, segundo o Painel Intergovernamental sobre Mudanças Climáticas (IPCC). Apontado na Conferência do Clima da ONU em Katowice, na Polônia, anualmente, cerca de 8 gigatoneladas de substâncias que favorecem o crescimento do aquecimento global, são geradas através desta atividade. 0 valor é 70 vezes maior do que há 30 anos atrás. (ONU, 2018).

Segundo os dados do $1^{\text {o }}$ Inventário Nacional de Emissões Atmosféricas por Veículos Automotores Rodoviários o setor de transportes é o que mais afeta expressivamente a qualidade do ar no Brasil, sendo o modal rodoviário o responsável pela emissão de $90 \%$ dos gases poluentes e do CO2 desta categoria. (MMA, 2010).

Considerando que a poluição atmosférica, em sua maioria, deriva da queima de combustíveis, e que os automotores possuem motor a combustão, que são máquinas responsáveis pela conversão de energia em trabalho mecânico através da queima de combustível, segundo Viscondi, Silva e Cunha (2016) a emissão dos gases de efeito estufa, como o CO2, está ligada ao tipo de combustível utilizado, bem como a eficiência na conversão de energia, sendo este o principal elemento resultante da intensidade dos poluentes lançados.

No caso do transporte rodoviário de cargas, visto que os veículos necessitam de grande potência, o óleo diesel é o combustível mais empregado. A exaustão diesel, entretanto, é mais complexa que a da gasolina. Esta operação em condições ótimas, resulta em menor produção de Dióxido de Carbono (CO2). E em um processo de combustão em condições propícias, tem-se por consequência, inclusive, a emissão de menor quantidade de Dióxido de Nitrogênio (NO2), monóxido de Carbono (CO) e hidrocarbonetos (HC) que a gasolina. Todavia, a combustão do diesel resulta, justamente, em níveis altos de emissão de material particulado (MP) e de compostos responsáveis pelo odor característico da emissão diesel, sendo a liberação deles altamente crítica. Os hidrocarbonetos das emissões do diesel são, em média, muito mais pesados; além disso, os hidrocarbonetos policíclicos aromáticos (HPA) e seus derivados alquímicos, podem resistir ao processo de combustão, evaporando-se para a atmosfera, contaminando-a. (APPEL; BRAUN; SCHMAL, 2003). 
O Ministério do Meio Ambiente (2020) classifica as substâncias conseguintes da queima de diesel como poluentes atmosféricos e dentre os diversos efeitos colaterais causados pela emissão desses gases, pode-se citar, de acordo com a intensidade e exposição: CO fadiga, dor no peito, asfixia e morte. MP - câncer respiratório, arteriosclerose, inflamação de pulmão, agravamento de sintomas de asma, etc. HC - são precursores para a formação do ozônio troposférico e apresentam potencial causador de efeito estufa (metano). NO2 altas concentrações podem levar a problemas respiratórios e pulmonares. No ambiente pode levar a formação de smog fotoquímico e a chuvas ácidas.

Observa-se que além do tipo de combustível utilizado na geração de energia dos automotores, outros fatores influenciam nos impactos ambientais deste modal. 0 tempo de vida dos veículos da frota brasileira é alta, de forma geral, a idade média de caminhões atuando é de 11,9 anos. Além disso, a qualidade infra estrutural da malha rodoviária brasileira é avaliada de forma negativa, $59 \%$ de sua extensão total é classificada de regular a péssima, conforme informações da Anuário CNT de Transporte de 2019, o que reflete diretamente na eficiência do transporte e na emissão de poluentes.

\section{RESULTADOS E DISCUSSÃO}

Com base nos dados apresentados, o presente trabalho visa apresentar uma alternativa viável ao transporte rodoviário nas operações de carne bovina no porto de Santos, focando principalmente na operação de transporte de cargas em grandes quantidades, aumentando a capacidade diária de movimentação, reduzindo custos operacionais e trazendo uma solução ambiental de redução da emissão gases estufa na atmosfera, para isto, será elaborado um plano de atendimento ao principal polo produtivo da carne bovina "in natura", localizado no eixo Mato Grosso do Sul - Mato Grosso - Goiás, onde há a maior concentração de plantas produtivas do 3 maiores frigoríficos do país em números de abate por dia, respectivamente a Friboi, Marfrig e Minerva Foods.

\subsection{MODAL FERROVIÁRIO COMO OPÇÃO ECONÔMICA E SUSTENTÁVEL}

O modal ferroviário é conhecido por sua grande capacidade de carga, baixo custo operacional e de manutenção, ser pouco poluente, etc. 0 próprio Ministério de Infraestrutura, enfatiza essas características e ainda diz que este modal tem maior eficiência energética, é adequado para longas distâncias e é mais seguro que o transporte rodoviário, em relação a furtos e acidentes. 0 Brasil teve a sua primeira ferrovia em 1854, a Estrada de Ferro Mauá, que foi de suma importância para a industrialização de nosso país, e resultou em alguns anos de investimento na estrutura ferroviária brasileira, apesar disso com a início do governo de Juscelino Kubitschek, os investimentos em estrutura foram direcionados para o desenvolvimento do modal rodoviário, deixando as ferrovias e seu grande potencial de lado. (ABINFER, 2020).

Na década de 1990, o governo brasileiro criou o Programa Nacional de Desestatização, concedendo ao setor privado a operação e o cuidado de algumas malhas ferroviárias. Segundo a Agencia Nacional de Transporte Ferroviário - ANFT, atualmente, foram concedidos $28.190 \mathrm{~km}$ de extensão da malha ferroviária. Com as concessões foi observado que o volume de carga transportado pelo modal ferroviário teve um aumento significativo, e que em 2019 foi transportado cerca de 493,8 milhões de toneladas úteis (TU), um crescimento de 95\% desde o início das concessões, quando havia sido movimentado 253 milhões de toneladas úteis (ANTF, 2020). Como consequência das 
concessões, os investimentos na malha ferroviária cresceram exponencialmente, conforme informado pela ANTR "as ferrovias já investiram mais de R 75 bilhões (valores correntes), que representam mais de $\mathrm{R} \$ 113$ bilhões se atualizados pelo IPCA de 2019". Dentre as diversas aplicações, os investimentos visaram a melhora da malha ferroviária, sua atualização tecnológica e a capacitação dos seus operadores.

A questão de segurança é outro motivo pelo qual a ferrovia se destaca em relação ao transporte rodoviário, foi apurado que entre 1996 e 2019, as ferrovias associadas à ANTF tiveram uma redução de cerca de $85 \%$ referente ao Índice de Acidentes Ferroviário - IAF, conservando padrões internacionais de segurança (ANTF, 2020). Conforme pode ser observado no gráfico 1 :

Gráfico 1 - Segurança

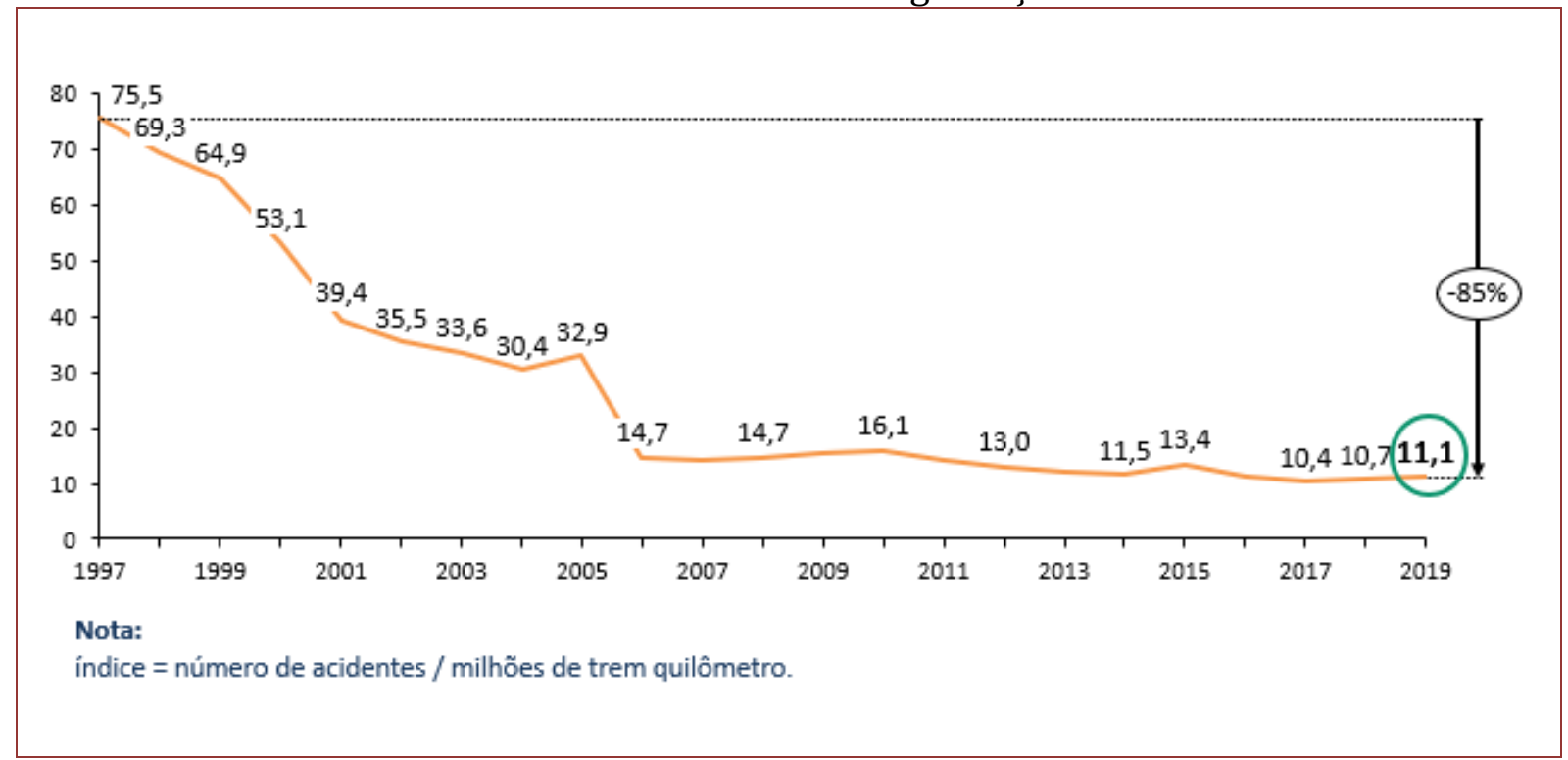

Fonte: ANTR, 2020

Conforme a apuração feita por Eller, Junior e Curi (2011), os custos totais comparados entre o transportes rodoviário e ferroviário, conforme Tabela 3, apontam que as ferrovias tem o menor valor em sua esfera global, incluindo a questão social-ambiental. No artigo, os autores destacam que desconsiderando as questões ambientais e sociais, as rodovias são mais "em conta", justificando o histórico brasileiro em investir no modal rodoviário, porém, levando-se em conta os custos ditos como "custos explícitos (internos) e os custos implícitos (externos)", o modal ferroviário apresenta-se como o melhor em relação ao meio ambiente, devido ao seu baixo impacto ambiental, como por exemplo o desmatamento, o que não pode ser afirmado em relação as rodovias, que apresentam um alto grau de desmatamento, não somente para a construção da via, mas também, em seus arredores para a instalação de residências e comércio. 
Tabela 3 - Custos comparados dos modais rodoviário e ferroviário no Brasil, por tonelada-quilômetro útil, em 2009

\begin{tabular}{|c|c|c}
\hline \multirow{2}{*}{} & Rodoviário (R\$) & Ferroviário (RS) \\
\cline { 2 - 3 } & $1.861 .523 .896,20$ & $1.981 .296 .580,00$ \\
\hline Implantação & $34.000 .000,00$ & $5.480 .960,00$ \\
\hline Manutenção da via & 36,36 & 13,40 \\
\hline Operação do veículo & 35,08 & $137.520,92$ \\
\hline Manutenção do veículo & $3.583 .242 .621,60$ & $716.648 .524,32$ \\
\hline Meio ambiente & $\mathbf{5 . 4 7 8 . 7 6 6 . 5 8 9 , 2 4}$ & $\mathbf{2 . 7 0 3 . 5 6 3 . 5 9 8 , 6 4}$ \\
\hline Totais & \\
\hline
\end{tabular}

Fonte: Eller; Junior e Curi (2011)

E por fim, a questão ambiental também deve ser levada em conta, visto que um vagão graneleiro, com capacidade para 100 toneladas, tem a capacidade de substituir cerca de quatro caminhões, abrandando o transito e congestionamentos nas rodovias e cidades, diminuindo, por conseguinte, o impacto ambiental (ANTF,2020).

\subsection{INTERMODALIDADE E O COMPLEXO INTERMODAL DE RONDONÓPOLIS}

A escolha do modal a ser utilizado é de estrema importância nas operações logísticas, ela é quem definirá o custo da operação, bem como a sua eficiência. Para tanto, deve analisada as condições da carga, suas características, a distancia a ser percorrida, bem como as necessidades do cliente. Como cada modal é único e tem suas próprias características, suas vantagens e desvantagens, ao se fazer a combinação de um ou mais tipos de transporte, será possível englobar mais de um benefício, abrangendo tanto a questão de serviço, como de custo. A intermodalidade tem como objetivo proporcionar esta integração da forma mais eficaz possível, conseguindo superar as limitações de um só modal.

Inaugurado em 2013 pela empresa ALL, atual Rumo Logística, o terminal intermodal de Rondonópolis, tornou-se o maior corredor de exportação do pais rumo ao porto de Santos, sendo reconhecido como o maior complexo intermodal da América Latina. A empreitada tem como objetivo conectar as BRs 163 e 364, por onde flui grande parte da produção de agropecuária do estado ao porto de Santos/SP.

Segundo a revista ISTO É Dinheiro (2015), o investimento feito pela ALL, nos próximos anos, contemplará a acomodação de outras empresas de diversos seguimentos, e esperase que haja uma alta nas vagas de empregos disponíveis gerados pelas novas empresas que farão parte do complexo, tendo por consequência aumento do PIB da cidade que deve dobrar impactando toda a cadeia logística, desde as fazendas do norte do Estado, até os pequenos comerciantes locais. O Complexo de Rondonópolis se encontra uma região estratégica ao lado da BR-163, uma das principais rodovias que ligam o Centrooeste ao Norte e ao Sul do Brasil, sendo um ponto chave quando se trata da intermodalidade, visto que a área onde o terminal se situa é próxima aos principais 
frigoríficos do Brasil, tornando-se um canal para a distribuição da carne bovina produzida na região direto ao porto de Santos.

\section{CONSIDERAÇÕES FINAIS}

Todos os anos o Brasil produz toneladas de carne bovina, e parte dessa produção é exportada para outros países, sendo Santos o principal porto de embarque. Considerando que o modal rodoviário é o mais utilizado para o escoamento da carne para o porto, notou-se que este modal, também é o mais caro para transporte interno, além de ser o mais nocivo ao meio ambiente por conta da emissão de $\mathrm{CO} 2$ e outros gases advindos da combustão de combustíveis fósseis.

Após a realização deste estudo, foi verificado que existem melhores soluções logísticas a serem exploradas para que a carne bovina chegue de forma mais eficiente no de Santos, sendo está mais sustentável, rápida e menos custosa. Com base nos dados apresentados pelo presente estudo, averiguou-se que o modal rodoviário (usado atualmente) apresenta uma serie de desvantagens, fazendo com que uma alternativa mais sustentável e econômica fosse necessária pra otimizar o escoamento da carne ao destino final, com isso, um projeto de viabilidade de um trecho intermodal que liga a macrorregião de Rondonópolis ao porto de Santos por vias ferroviárias, movimentando boa parte da produção dos 74 frigoríficos localizados nas proximidades que juntos somam 51,3\% da produção nacional de proteína animal, foi escolhido a fim de utilizar os benefícios da intermodalidade para potencializar a capacidade de distribuição deste commodity para o porto.

Conforme apresentado, a redução de impactos ambientais por caminhões, que deixarão de estar nas rodovias, a redução de custos logísticos, através da troca do modal principal uma vez que uma única composição pode retirar vários caminhões das rodovias com preços mais competitivos e com maior confiabilidade, impactará positivamente no trânsito, desafogando as vias e melhorando a qualidade das rodovias, já que os veículos de carga são os principais agentes de deterioração do asfalto, além de tornar a região de Rondonópolis um centro logístico completo e ponto estratégico para o escoamento da carne bovina brasileira para o mercado externo.

\section{REFERÊNCIAS}

[1]. ABIEC. Beef Report 2020, [S. l.], ano 2020, 9 out. 2020. Disponível em: http://abiec.com.br/publicacoes/beef-report-2020/. Acesso em: 26 out. 2020.

[2]. ABIFER - Transporte ferroviário: há futuro para uma logística mais eficiente e com mais qualidade?. 2018. Disponível em: https://abifer.org.br/transporte-ferroviario-ha-futuro-parauma-logistica-mais-eficiente-e-com-mais-qualidade/. Acesso em: 04.nov.2020.

[3]. AGENCIA NACIONAL DE TRANSPORTES. Anuário CNT do Transporte 2018. 2018. Disponível em: https://anuariodotransporte.cnt.org.br/2018/File/PrincipaisDados.pdf. Acesso em: 29 set. 2020.

[4]. APPEL, L. G.; BRAUN, S.; SCHMAL, M. A poluição gerada por máquinas de combustão interna movidas à diesel - a questão dos particulados. Estratégias atuais para a redução e controle das emissões e tendências futuras. Quim. Nova, Vol. 27, No. 3, 472-482, 2003. Disponível em: https://www.scielo.br/pdf/qn/v27n3/20176. Acesso em: 29 set. 2020.

[5]. CARVALHO, C. H. R. de. Emissões relativas de poluentes do Transporte urbano. Boletim regional, urbano e ambiental - IPEA. 2011. Disponível em: 
http://repositorio.ipea.gov.br/bitstream/11058/5574/1/BRU_n05_emiss\%C3\%B5es.pdf. Acesso em: 07 set. 2020.

[6]. CONFEDERAÇÃO NASCIONAL DO TRANSPORTE - Boletim Econômico - Dezembro 2019. 2019. Disponível em: https://www.cnt.org.br/boletins/. Acesso em: 05.set.2020.

[7]. ELLER, R. de A. G.; JUNIOR, W. C. de S.; CURI, M. L. C. Custos do transporte de carga no Brasil: rodoviário versus ferroviário. Journal of Transport Literature. Vol. 5, n. 1, pp. 50-64, Jan. 2011. Disponível em:

http://estacio.webaula.com.br/BiBlioTECA/Acervo/Complementar/Complementar_41411.pdf. Acesso em: 04.nov.2020

[8]. GASQUES, J. G. et al. Produtividade total dos fatores e transformações da agricultura brasileira: análise dos dados dos censos agropecuários. In: GASQUES, J. G.; VIEIRA FILHO, J. E. R.; NAVARRO, Z. (Org.). A agricultura brasileira: desempenho, desafios e perspectivas. Brasília: Ipea, 2010. p. 19-44.

[9]. GERHARDT, T. E.; SILVEIRA, D. T. Métodos de Pesquisa. 1a. ed. Rio Grande do Sul: Editora UFRGDS, 2009. Disponível em: http://www.ufrgs.br/cursopgdr/downloadsSerie/derad005.pdf. Acesso em: 17 sep. 2020.

[10]. ISTOÉ Dinheiro. As 1.000 Maiores da Dinheiro, [S. l.], 9 out. 2020. Disponível em: https://www.istoedinheiro.com.br/as-1-000-maiores-da-dinheiro-2/. Acesso em: 26 out. 2020.

[11]. KEEDI, Samir. Logística, Transporte, Comércio Exterior e Economia em Conta-Gotas. 2.ed. São Paulo: Aduaneiras, 2014

[12]. MINISTÉRIO DA INFRAESTRUTURA. Anuário Estatístico de Transportes. 2018.

Disponível em: https://www.gov.br/infraestrutura/pt-br/centrais-de-conteudo/suma-exec-aet2010-2018-pdf. Acesso em: 29 set. 2020.

[13]. MINISTÉRIO DA INFRAESTRUTURA - Transporte Ferroviário. 2016. Disponível em: https://canaldoservidor.infraestrutura.gov.br/conteudo/52-sistema-de-transportes/2849transporte-ferroviario.html. Acesso em: 04.nov.2020.

[14]. MINISTÉRIO DA INFRAESTRUTURA - Ferrovias Brasileiras. 2019. Disponível em: https://www.antf.org.br/informacoes-gerais/. Acesso em: 04.nov.2020.

[15]. MINISTÉRIO DO MEIO AMBIENTE - Poluentes Atmosféricos. 2020. Disponível em: https://www.mma.gov.br/cidades-sustentaveis/qualidade-do-ar/poluentesatmosf\%C3\%A9ricos.html. Acesso em: 07.set.2020.

[16]. MINISTÉRIO DO MEIO AMBIENTE - Setor De Transporte É O Que Causa Mais Impactos Na Qualidade Do Ar. 2010. Disponível em: https://www.mma.gov.br/informma/item/6191setor-de-transporte-e-o-que-causa-mais-impactos-na-qualidade-do-ar. Acesso em: 05.set.2020.

[17]. ORGANIZAÇÃO DAS NAÇÕES UNIDAS - BRASIL. Transporte Sustentável É Destaque Na Conferência Do Clima Da ONU. 2018. Disponível em: https://nacoesunidas.org/transportesustentavel-e-destaque-na-conferencia-do-clima-da-onu/. Acesso em: 07.set.2020.

[18]. RODRIGUES, P. R. A. Introdução aos Sistemas de Transporte no Brasil e à Logística Internacional. São Paulo: Aduaneiras, 2014.

[19]. VISCONDI, G. F.; SILVA, A. F.; CUNHA, K. B. Geração Termoelétrica E Emissões Atmosféricas: Poluentes E Sistemas De Controle. São Paulo: IEMA, 2016. Disponível em: https://iema-site-staging.s3.amazonaws.com/IEMA-EMISSOES.pdf. Acesso em: 05 set.2020. 


\section{Capítulo 2}

Cargas especiais: A problemática do transporte de cargas vivas

Fábio Aparecido Ruiz Junior

Luccas Moura Jugo Ramos da Conceição

Viviane Marques Felix

Resumo: As Cargas especiais são aquelas que não se enquadram nas Resoluções 12/98 e 68/98 do Conselho Nacional de Trânsito (CONTRAN), e requerem um maior cuidado para a sua movimentação. 0 transporte de animais, que é chamado de carga viva, é um dos mais complexos de se realizar, exige muita cautela para não prejudicar a vida e saúde do animal transportado. 0 artigo tem como objetivo analisar toda a cadeia logística de transporte de animais, e verificar as maiores problemáticas existentes dentro do ramo. Justifica-se o estudo desse tema com a importância da monitoria dentro desse tipo de carga.

Palavras-chave: Cargas Especiais. Cargas Vivas. Transporte. Animais. 


\section{INTRODUÇÃO}

Há cerca de 20 anos, o Brasil transporta cargas vivas, com a utilização do modal rodoviário os animais vão da fazendo até o porto, os principais países compradores são de outros continentes, e por conta disso é utilizado o modal marítimo.

Esse setor apresenta um grande crescimento no comércio internacional por questões religiosas e culturais dos países compradores, que têm seu corte definido de acordo com a sua cultura, o que é preferível então a compra do boi vivo e não da carne já processada.

No ano de 2017, iniciou-se a Operação Carne Fraca, que apreendeu cerca de 30 frigoríficos que tiveram seus certificados de qualidade adulterados. Foram encontrados carnes congeladas adulteradas, e a PF chegou a afirmar que algumas empresas adicionavam papelão à carne. Empresas como a JBS, dona da Friboi e Seara, e a BRF, dona da Sadia e da Perdigão, estavam envolvidas na operação.

Esse fato acarretou no disparo de vendas de boi vivo, já que as carnes congeladas processadas pelas empresas passaram a ser alvo de desconfiança dos compradores.Com o aumento das exportação de cargas vivas, foi necessário maiores planejamentos, investimentos e fiscalizações dese transporte.

O objetivo do artigo é mostrar porque se faz necessária a conscientização de todos os trâmites necessários para a transporte de cargas vivas, visando sempre estar dentro das regulamentação nacionais e internacionais, que prezam o bem-estar dos animais durante todo o seu percurso até o destino.

É uma pesquisa quali-quantitativa, onde apresentamos dados estatísticos para fins de estudo e trabalhamos com ideias e teses, para tentar identificar os problemas da cadeia de exportação de cargas vivas.

\section{EMBASAMENTO TEÓRICO}

Segundo Ballou (2006), a Cadeia de Suprimentos é um conjunto de atividadesfuncionais, que se repetem ao longo do percurso pelo qual a matéria-prima se convertem em produtos, aos quais no final do processo agregam valor ao consumidor. 0 transporte representa o elemento mais importante quando se trata de custos logísticos para inúmeras empresas. 0 transporte de cargas consome dois terços dos custos logísticos totais de uma cadeia de suprimentos. 


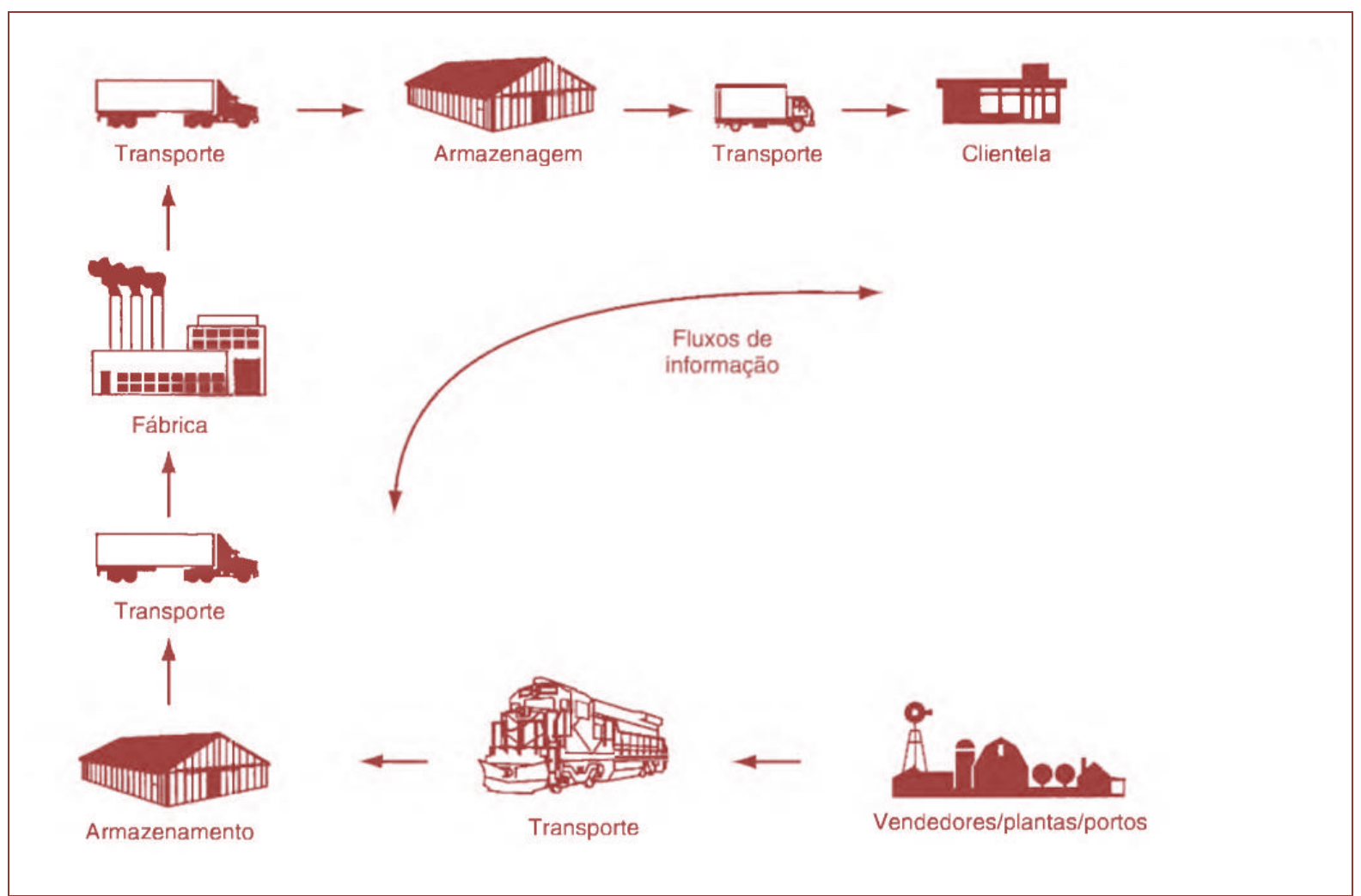

Fonte: Ballou (2006).

As cargas especiais são aquelas que requerem um cuidado especial para a sua movimentação, como por exemplo, eletrônicos, medicamentos, cargas refrigeradas, e cargas vivas.

0 transporte de animais vivos é um dos que mais exigem cautela na hora de ser realizado, já que trata-se de seres vivos sendo transportados, as regulamentações nacionais e internacionais são bem rígidas quando se trata dessa movimentação.

\section{A REGULAMENTAÇÃO GERAL DO TRANSPORTE DE ANIMAIS VIVOS}

0 transporte de cargas vivas possui uma regulamentação que tem como objetivo evitar o sofrimento dos animais, e diminuir o risco de problemas de saúde dos animais, é necessário um caminhão adaptado para evitar problemas com o animal durante o trajeto, dispor de algum meio para que seja possível a visualização parcial ou total dos animais, e os veículos também precisam ter uma abertura para embarque e desembarque com mecanismo de travamento, entre outros.

No Porto de Santos, discutiu-se a proibição desse tipo de transporte depois do embarque de 27 mil bois em um návio destinado à Turquia, que ficou parado por 13 dias no porto, trazendo mau cheiro e ativistas alegaram maus-tratos, e um laudo da Vigilância Agropecuária afastou irregularidades.

Em outros portos brasileiros, como os do Paraná, também apresentaram irregularidades sobre esse tipo de movimentação. Em julho de 2019, quatro mil bois vivos deveriam embarcar no porto de Antonina pelo Terminal Ponta do Félix, mas geraram discussões pois o Ministério Público do Paraná (MPPR), expediu uma recomendação do Instituto Ambiental do Paraná (IAP) que anulava a autorização da exportação de cargas vivas. 0 
MPPR alegou que o Porto de Antonina não possui a estrutura e as condições necessária para esse tipo de operação, além de não aprsentar as devidas licenças ambientais, urbanísticas e sanitárias.

Portanto, esse tipo de movimentação não é nada simples, exige uma grande responsabilidade e possui regramentos nacionais e internacionais e monitoramento de profissionais do Ministério da Agricultura, Pecuária e Abastecimento (Mapa) do ínicio ao fim.

\subsection{REGULAMENTAÇÃO INTERNACIONAL DO TRANSPORTE DE CARGAS VIVAS}

O Brasil é assinante da Organização Mundial da Saúde Animal (OIE) e então tem a obrigação de cumprir procedimentos operacionais regulamentados pelo Mapa. A Coordenação de Boas Práticas e Bem-estar Animal (CBPA) reconhece que é necessária a aplicação das recomendações da OIE para o resguardo da agropecuária nacional.

As normas impostas pela OIE não devem ser vistas como entraves aos negócios, por apresentar uma medida protetiva aos animais. 0 transporte tem de seguir todas as normas da OIE, mas também apresentar os documentos EPE e ACZI.

O EPE é o local onde são realizadas as documentações do pré-embarque, no Brasil existem 41 EPEs em seis estados diferentes. Quando o animal chega ao aeroporto, uma série de documentação é realizada uma semana antes de seu embarque, quando enviado à RFB, os ficais carimbam e então despacham o EPE para que o representante responsável no aeroporto continue o trâmite do transporte.

O ACZI é emitido quando o processo de pré-embarque finaliza, os veterinários do Mapa emitem o ACZI que libera os animais a serem transportados pela empresa responsável. Para receber o certificado de exportação, o responsável entra emcontato com o setor de saúde animal da Superintendência Federal da Agricultura (SFA) do estado ou com o Sistema de Vigilância Agropecuária (Vigiagro).

\subsection{REGULAMENTAÇÃO NACIONAL DO TRANSPORTE DE CARGAS VIVAS}

No Brasil, são dois os orgãos que cuidam das normas sobre o transporte de animais:a Receita Federal do Brasil (RFB) e o Ministério da Agricultura, Pecuária e Abastecimento (MAPA), eles são responsáveis por liberar o animal e conceder os certificados necessários para que eles entrem ou saiam do país. E para acontecer o transporte, é necessária uma análise do peso e tamanho do animal, chegando a umacotação que então é verificada pela companhia em relação ao embarque, e também pode influenciar a cotação os seguintes fatores: raça, tamanho, peso, idade, origem edestino do animal.

As principais regras para o transporte de cargas vivas são:

- O meio de transporte deve possuir de espaço suficiente para o animal ficarem pé, em sua posição comum, assim como necessita de espaço para o animal se deitar;

- É proibido o transporte de outras cargas no mesmo compartimento dos animais, para que não sejam machucados;

- O veículo deve estar em boas condições para que os animais não escorreguem, e a serragem se utilizada não deve ser muito fina para não lesionar os olhos do animal; 
- O veículo tem que estar marcado com um símbolo indicando que o mesmo esta transportando cargas vivas, e um que indique a posição em que os animais se encontram, e devem permitir a inspeção e tratamentos necessários ao animal, e a circulação de ar;

- Se houver a necessidade dos animais viajarem presos, eles devem ser amarrados com o comprimento suficiente para que eles possam comer, beber e se deitar, e as amarras devem ser feitas de modo que evite o estrangulamento do animal, e nunca devem ser feitas nos chifres;

- No embarque e desembarque, deve-se ter o máximo cuidado para que os animais não sofram lesões, e é necessário cautela pois eles podem estranhar mudanças de ambiente;

- Atentar-se ao tempo que o animal permanecerá embarcado, pois eles possuem limites que se ultrapassados podem deixar o animal estressado.

As regras devem ser exercidas pelo condutor, pelo proprietário do veículo e pelo donodos animais, e o descumprimento de algumas dessas normas gera multas previstas na Lei dos Crimes Ambientais (Lei n.o 9.605/98), assim como as normas de sanidade agropecuária e da proteção animal.

Ricardo Pereira, presidente da Associação dos Exportadores de Animais Vivos (Abreav), afirma que o Brasil segue rigorosamente as normas da OIE.

"Não tenho dúvidas da qualidade do atendimento dos animais. 0 percentual que fica doente é muito baixo. Todos os transportados são examinados. Os estabelecimentos são monitorados e possuem certificação do Mapa."

\subsection{CASOS EM PORTOS BRASILEIROS}

Em dezembro de 2017, após quase duas decadas sem a movimentação de cargas vivas, o Porto de Santos embarcou 27 mil bois no navio Nada - o maior em relação a movimentaçao de cargas vivas no mundo - destinado a Turquia.

Após 6 dias embarcado, o navio Nada foi suspenso por ordem judicial, ativistas da proteção animal alegaram maus-tratos e a prefeitura de Santos multou a empresa responsável pelos animais, em $\mathrm{R} \$ 1,5$ milhão por maus-tratos, e também por poluição ambiental, em R $\$ 2$ milhões.

A discussão gerou a criação de um projeto de lei que proibiria a movimentação de cargas vivas pelo Porto de Santos, e foi aprovado na Câmara Municipal, porém gerourevolta ao Ministério da Agricultura e de entidades que representam o setor agropecuário, que conseguiram derrubar a lei.

Em 2015, no nordeste do Pará, no Porto de Barcarena, líder de exportação de bois vivos, um navio que transportava cerca de 5 mil bois vivos afundou, o naufrágio aconteceu duas horas depois da embarcação ter tombado. Muitos animais subiram na lateral da embarcação que estava parcialmente submersa, tentando se salvar.

A Prefeitura de Barcarena tentou controlar a retirada dos animais indo até o local com equipes das polícias ambiental e militar também da Defesa de Higiene. 
Segundo Adepará, apenas 40 bois escaparam do naufrágio, e a Defensoria entrou com uma ação civil pública contra as empresas responsáveis pelo desastre ambiental, que também despejaram muitos litros de óleo no rio Pará.

\section{RESULTADOS E DISCUSSÕES}

A movimentação de animais vivos é uma das mais lucrativas no Brasil, que crescem desenfreadamente, só no ano de 2017 obteve-se um crescimento de 40\%, atingindo o lucro de US\$269,57 milhões, afirma o Ministério da Indústria, Comércio Exterior e Serviços (MDIC).

Ainda assim, faz-se necessária a inspeção rigorosa sobre as condições dos animais e dos seus meios de transporte, tendo cautela com a saúde, alimentação e segurança dos animais sem esquecer de que os direitos dos animais fazem parte de um assunto de interesse ambiental, cultural e social, além do lucro de grandes empresas. Portanto de acordo com as normas e medidas de proteção aos animais, o art. 1ํo do decreto n.19.398, de 11 de novembro de 1930 afirma que todos os animais existentes no país são tutelados do Estado.

Conclui-se que para manter uma boa economia e seguir com resultados superavitários, o Brasil deve seguir todas as regulamentações previstas em lei, e manter o seu modal de transporte em boas condiçoes, visto que segundo o autor Ballou (2006), um sistema de transporte é eficaz para o crescimento econômico de um país.

\section{CONSIDERAÇÕES FINAIS}

Essa pesquisa se propôs, como objetivo geral, apontar a necessidade de seguimento de todas as regras para o transporte de cargas vivas, apresentando casos em portos brasileiros que mostraram que não estava sendo seguido da maneira correta o que acarretou em problemas, tanto no Porto de Santos quanto no Porto de Barcarena, o que ao final gerou prejuízos milionários em multas, e perda de cargas.

Dessa forma, é essencial que mantenha-se sempre uma fiscalização em toda a cadeia logística do transporte de animais, desde a fazenda até o seu destino final.

\section{REFERÊNCIAS}

[1]. CASTRO, A.M.G. DE; LIMA, S. M. V.; HOEFLICH, V. As Cadeias Produtivas. UFSC/Senar/Embrapa, Florianópolis, 1999.

[2]. COWSPIRACY. Direção: Kip Andersen. Produção de Appian Way Productions. Estados Unidos: Netflix, 2014.

[3]. EXAME, Entenda o que é a operação Carne Fraca e os impactos para a BRF. Disponível em: https://exame.com/negocios/entenda-o-que-e-a-operacao-carne- fraca-e-os-impactospara-a-brf/. Acesso em 10 de jul de 2020.

[4]. EXPORTANDO VIDAS. Disponível em: https://exportandovidas.com.br. Acesso em 14 jun. 2020.

[5]. Porto de Santos concentra apenas 6,6\% de exportações de boi vivo. InvestSP. Disponível em: https://www.investe.sp.gov.br/noticia/porto-de-santos-concentra- apenas-6-6-deexportacoes-de-boi-vivo/. Acesso em 12 jun. 2020. 
[6]. FÓRUM NACIONAL DE PROTEÇÃO E DEFESA ANIMAL. Disponível em: https://forumanimal.org. Acesso em 14 jun. 2020.

[7]. RESOLUÇÃO № 12/98 DO CONTRAN. Guia do TRC. Disponível em: http://www.guiadotrc.com.br/lei/res1298.asp. Acesso em 12 jun. 2020.

[8]. CÂMARA DOS DEPUTADOS. Legislação. Disponível em: http://www2.camara.leg.br/legin/fed/decret/1930-1939/decreto-24645-10-julho-1934516837-norma-pe.html. Acesso em: 10 jun. 2020.

[9]. Sancionada lei que proíbe circulação e transporte de cargas vivas em Santos. Prefeitura de Santos. Disponível em: https://www.santos.sp.gov.br/?q=noticia/sancionada-lei-que-proibecirculacao-e- transporte-de-cargas-vivas-em-santos. Acesso em 12 jun. 2020.

[10]. Governo derruba liminar e navio com mais de 25 mil bois deixa o Porto de Santos. G1. Disponível em: https://g1.globo.com/sp/santos-regiao/porto- mar/noticia/governo-derrubaliminar-e-navio-com-mais-de-25-mil-bois-deixa-o-porto- de-santos.ghtml. Acesso em 12 jun. 2020.

[11]. MAPA. Ministério da Agricultura, Pecuária e Abastecimento. Disponível em: https://www.gov.br/agricultura/pt-br. Acesso em 10 de jul. 2020.

[12]. MDIC. Ministério da Indústria, Comércio Exterior e Serviços. Disponível em: https://www.gov.br/produtividade-e-comercio-exterior/pt-br. Acesso em 10 de jul. 2020.

[13]. Scot Consultoria. Disponível em: https://www.scotconsultoria.com.br/?ref=mnp. Acesso em 14 jun. 2020.

[14]. Fórum Nacional de Educação. Disponível em: http://fne.mec.gov.br. Acesso em 15 jun. 2020 .

[15]. BALLOU, Ronald H. Gerenciamento da Cadeia de Suprimentos/Logística Empresarial, $5^{\circ}$ edição. Ed Bookilometroan.

[16]. Embarcação afunda e bois tentam escapar de naufrágia em Barcarena. G1. Disponível em: http://g1.globo.com/pa/para/noticia/2015/10/embarcacao-afunda-e- bois-tentam-escapar-denaufragio-em-barcarena.html. Acesso em 14 jun. 2020.

[17]. Defensoria vai acionar responsáveis por dano ambiental em Barcarena. G1. Disponível em: http://g1.globo.com/pa/para/noticia/2015/12/defensoria-vai-acionar- responsaveis-pordano-ambiental-em-barcarena.html. Acesso em 14 jun. 2020. 


\section{Capítulo 3}

Indicadores de desempenho e os respectivos resultados na exportação de celulose através do porto de Santos

\section{Tiago Silva Santa Rosa}

Resumo: A proposta deste artigo é demonstrar o processo da exportação de celulose no país pelo Porto de Santos mostrando o desempenho na economia e os respectivos resultados na exportação de celulose no país, partindo da sua produção, logística, armazenamento e embarque. O objetivo desse estudo é apresentar o aumento expressivo da exportação de celulose, bem como o país se tornou o maior exportador mundial de celulose e o segundo maior produtor do mundo, gerando diversos investimentos com o objetivo de aprimorar a sua logística desde a fábrica até o embarque, tendo em vista com a aprovação do novo PDZ, inúmeros projetos serão direcionados a armazenagem e movimentação da celulose em função ao uso do modal ferroviário, com aumento de tecnologia e equipamentos de última geração. Os resultados exibem que mesmo com um alto índice na produção e exportação da celulose, $o$ Brasil demonstra poucos investimentos em infraestrutura no transporte, uma carga tributária elevada em relação a concorrência internacional e com o uso errôneo intensivo do modal rodoviário ao invés do modal ferroviário.

Palavras-chave: Celulose, Logística, Exportação, Investimentos 


\section{INTRODUÇÃO}

Nos últimos anos a exportação da celulose tem alcançado números recordes no Brasil, tornando-se o maior exportador mundial de celulose e o segundo maior produtor ficando atrás apenas dos Estados Unidos. 0 país é beneficiado por obter um clima favorável para o desenvolvimento dessa commodities que se tornou um dos setores mais promissores do agronegócio. Contudo, o estado de Mato Grosso atualmente é considerado o maior produtor de celulose do país sendo que há outros estados com grande destaque nesse setor, responsáveis no ano de 2018 por uma relevante parcela referente as exportações: Bahia (17,8\%), Espírito Santo(11,1\%), Maranhão (10,4\%), Rio Grande do Sul (9,66\%) e Minas Gerais (9,26\%). No primeiro semestre de 2019, Rio Grande do Sul ficou em $2^{\circ}$ lugar no ranking de exportações desse semestre, com uma participação de 19,3 \% em relação a Bahia com 14,2 \%.

Este estudo tem o objetivo de demonstrar os indicadores de desempenho nas atividades portuárias e os respectivos resultados na exportação da celulose pelos portos do Brasil com uma centralização ao Porto de Santos, sendo o maior porto da América Latina e um dos mais importantes no escoamento da celulose para o mundo. Nesse estudo também é apresentado o aumento expressivo da produção em diversos estados na capacidade produtiva da indústria de celulose brasileira, as perspectivas do setor para os próximos anos e os desafios de uma logística mais eficaz desde a fabricação da celulose até a sua exportação.

\section{PRODUÇÃO DE CELULOSE NO BRASIL}

Em 1956 é inicada a produção de celulose se iniciando a partir da fibra de eucalipto, que revolucionou a indústria de celulose no Brasil e no mundo. Uma grande característica que fez com que o Brasil se tornasse em uma potência nesse segmento é a sua posição geografica no hemisfério sul, o eucalipto tem uma média de sete anos para alcançar a fase de corte, já no hemisfério norte, essa média de fase de corte passa para quarenta anos no minimo. Com um clima favorável e com o uso da biotecnologia e da engenharia genética, que auxilia na produtividade no setor, para uma produção de cerca de 1,5 milhão de ton. de celulose no Brasil requer 140 mil hectares de madeira, enquanto que na China é necessário 300 mil hectares. 0 custo de produção de celulose é o mais baixo do mundo e com o uso da tecnologia de clonagem de mudas desenvolvida por brasileiros entre pesquisas com empresas, Embrapa e outras universidades. A empresa Suzano foi a primeira empresa no mundo a produzir a celulose com $100 \%$ de fibra de eucalipto em escala industrial, após quatorze anos se iniciou o processo de exportação para o mercado europeu e em 1985 foi criado o Portocel (ES), nos dias de hoje é o único porto do Brasil especializado no embarque de celulose.

Desde 1990, de acordo com o Gráfico 1 abaixo, a produção brasileira de celulose de fibra curta de mercado passou de 1,4 para 7,7 milhões de toneladas por ano, superando a produção dos Estados Unidos. A indústria brasileira de celulose produziu, em 2006, mais de 11 milhões de toneladas, o que representou um aumento de 7,6\% em comparação com o ano anterior. Em 2007, a celulose obteve um crescimento de 5,5\% na produção (MADRUGA,2013). 
Gráfico 1 - Produção de celulose

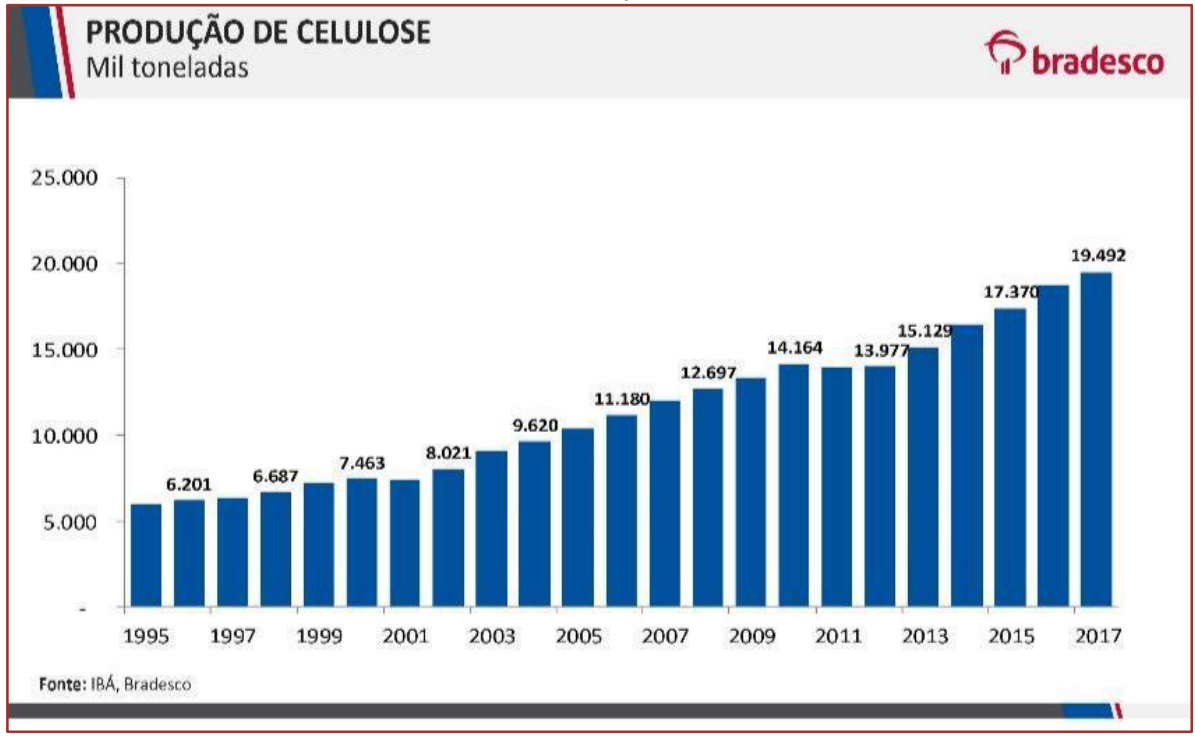

Fonte: IBÁ, Bradesco (2019)

Nos dias atuais, o Brasil se tornou o segundo maior produtor de celulose do mundo, ficando atrás apenas dos Estados Unidos, mas com uma grande capacidade de se tornar o primeiro do ranking. Conforme os dados da Indústria Brasileira de Árvores (Ibá), o Brasil obteve um aumento na produção em cerca de 21.085 milhões de toneladas, representando 8\% de aumento em relação ao ano 2017, que foi de 19.527 milhões.

\section{EXPORTAÇÃO DA CELULOSE}

De acordo com informações obtidas do Ministério da Indústria, Comércio Exterior e Serviços (MDIC) nos onze meses do ano de 2018, a celulose respondeu por cerca de $3,4 \%$ das exportações totais no Brasil, e em termos de receita, foi o quarto item principal da pauta exportadora nacional. A celulose manteve a liderança nas vendas externas de produtos semimanufaturados, respondendo por uma grande parcela de 26,8\% das exportações desse tipo de produtos.

Entre os anos de 2010 a 2018 a produção no estado de Mato Grosso do Sul alcançou a marca de 308\%, somando a 17 milhões de metros cúbicos de madeira em tora para celulose em 2018. Com esse crescimento, no ano de 2019, fez com que o estado atingisse o topo das exportações do produto no país, com 9,7 milhões de toneladas comercializadas: $22,20 \%$ do total nacional das exportações de celulose naquele ano.

Para Verruck da Secretária de Meio Ambiente, Desenvolvimento Econômico, Produção a Agricultura Familiar (SEMAGRO) denota-se que o desenvolvimento do setor florestal em Mato Grosso do Sul ao longo de toda uma década, com a celulose no topo do ranking, tem uma importância para novos investimentos e diversificação da economida do estado.

Atualmente, nos últimos 5 anos, Mato Grosso do Sul tem registrado um crescimento acima da média nacional na produção de celulose, obtendo um marca de 1 milhão de hectares de eucalipto cultivados, houve um grande aumento em seu parque industrial do setor e alcançou o primeiro lugar do país como o maior exportador do produto nos primeiros quatro meses de 2020, aponta os dados pela SEMAGRO com dados do IBGE e do MDIC. 
O cenário do mercado da exportação da celulose no Brasil demonstrou grande evolução em um período curto no cenário mundial, o Gráfico 2 abaixo, apresenta os dados do desenvolvimento do mercado no decorrer dos anos.

Gráfico 2 - Exportação da Celulose

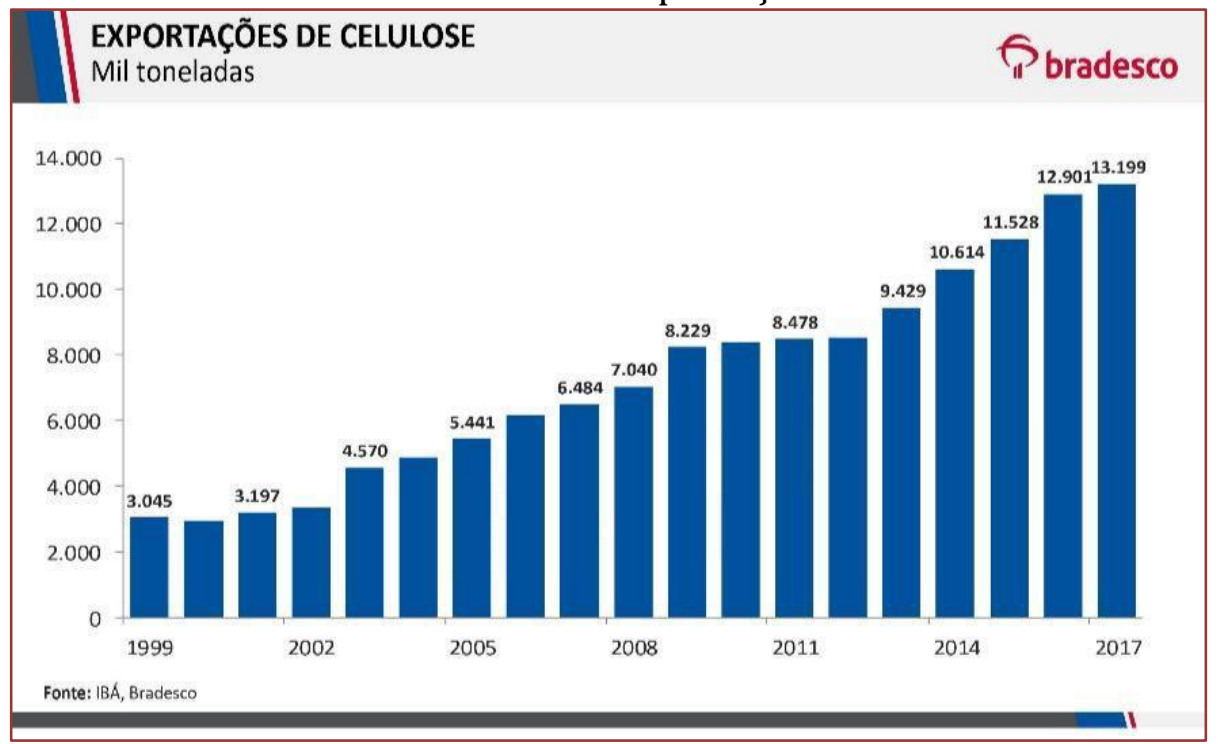

Fonte: IBÁ, Bradesco (2019)

O principal destino da celulose brasileira exportada é para a China, seguido dos Estados Unidos e da Europa, em 2017, conforme o Gráfico 3 abaixo é possível vizualizar esse ranking, tendo como a China o maior importador de celulose brasileira devido a uma nova reestruturação da política ambiental chinesa que tornou obrigatório ao próprio país a importar uma grande demanda de celulose, um ponto importante para o crescimento do segmento no Brasil.

Gráfico 3 - Principais destinos da celulose em 2017 ( em volume)

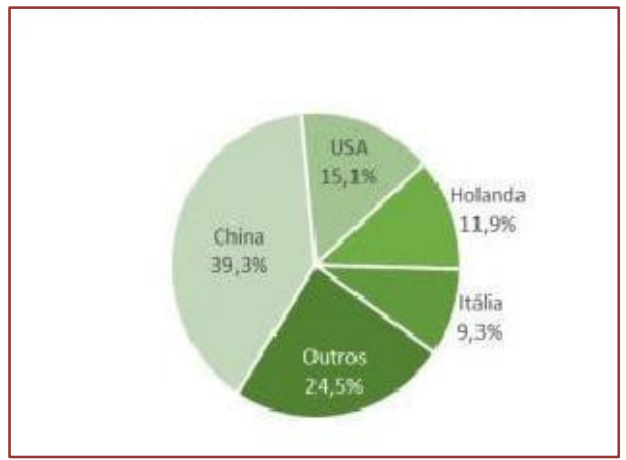

Fonte: Secretaria de Comércio Exterior (SECEX) (2018)

\section{LOGÍSITICA DA CELULOSE NO BRASIL}

Por serem produtos especificamente frágeis, a sua logística requer equipamentos específicos e atenção especial com o propósito de conservar as cargas a fim de evitar que sejam molhadas e consequentemente danificadas. A celulose tem a característica de matérias primas limpas, e a sua movimentação requer cuidados que são indispensáveis nessa operação logísitca, além de exigir um local asseado, recinto bem arejado e neutralização contra qualquer tipo de contaminações causadas por agentes plásticos ou 
de madeiras, que são exigências imprencidíveis. Por exigir um trabalho específico, com uma mão de obra especializada na logística portuária da celulose, as empresas estão investindo em diversos treinamentos especializados para os colaboradores com o foco de se obter uma boa qualidade e eficácia na movimentação do produto e com uma demanda maior de aquisição de equipamentos e máquinas de alta performance para uma melhoria do sistema logístico.

A logística tem um valor relevante em relação aos custos e também é um fator decisivo na competitividade. Para toda a cadeia logística da celulose, investimentos na infraestrutura no setor portuário é de grande importância, porém a competitividade brasileira tem redução pelos inúmeros encargos do custo Brasil, possuímos uma pesada carga tributária quando se comparada com a nossa concorrência internacional.

O gargalo logísitco no Brasil ainda é um grande divisor de águas, para uma redução desses cargalos à competitividade e ganho de produtividade, o país deveria investir cerca de 4,31 \% do PIB por ano, numa margem de no mínimo uma década seguida. Investimentos em infraestrutura é de grande importância para uma alavancada do crescimento econômico, em relação aos últimos 15 anos, o país investiu somente 2,40\% do PIB, com poucos investimentos no decorrer dos anos houveram grandes consequências em infraestrutura, que em meados da década de 1980 era de 58,3\% do PIB e já no ano de 2016 era de 36,2\% gerando assim uma grande defasagem brasileira.

Essa defasagem na infraestrutura de transportes tem um choque significativo para o país em comparações ao desempenho lógístico, segundo o Banco Mundial que faz essa divulgação de dois em dois anos desde o ano de 2007. No ano de 2016, demonstrado na figura 1 abaixo, o Brasil estava na 55a colocação, ficando a frente da Rússia entre os BRICS. Neste ranking, o Banco Mundial analisa seis itens (Consistência, Confiabilidade, Rastreamento de Carga, Competência dos Serviços, Disponibilidade de Transporte, Procedimento de Alfândega e Infraestrutura).

Figura 1 - Ranking do Índice de Desempenho Logístico do Banco Mundial 2007 a 2016

\begin{tabular}{|c|c|c|c|c|c|c|c|c|c|c|c|}
\hline & & \multirow[b]{2}{*}{2007} & \multicolumn{4}{|c|}{ Desempenho Logistico } & \multicolumn{5}{|c|}{ Infraestrutura } \\
\hline & & & 2010 & 2012 & 2014 & 2016 & 2007 & 2010 & 2012 & 2014 & 2016 \\
\hline & Alemanha & $3^{\circ}$ & $1^{\circ}$ & $4^{\circ}$ & $1^{\circ}$ & $1^{\circ}$ & $3^{\circ}$ & $1^{\circ}$ & $1^{\circ}$ & $1^{\circ}$ & $1^{\circ}$ \\
\hline & Luxemburgo & $23^{\circ}$ & $5^{\circ}$ & $15^{\circ}$ & $8^{\circ}$ & $2^{\circ}$ & $13^{\circ}$ & $9^{\circ}$ & $20^{\circ}$ & $15^{\circ}$ & $4^{\circ}$ \\
\hline & Suécia & $4^{\circ}$ & $3^{\circ}$ & $13^{\circ}$ & $6^{\circ}$ & $3^{\circ}$ & $5^{\circ}$ & $10^{\circ}$ & $5^{\circ}$ & $9^{\circ}$ & $3^{\circ}$ \\
\hline & Holanda & $2^{\circ}$ & $4^{\circ}$ & $5^{\circ}$ & $2^{\circ}$ & $4^{\circ}$ & $1^{\circ}$ & $2^{\circ}$ & $3^{\circ}$ & $3^{\circ}$ & $2^{\circ}$ \\
\hline र्ञ & Cingapura & $1^{\circ}$ & $2^{\circ}$ & $1^{\circ}$ & $5^{\circ}$ & $5^{\circ}$ & $2^{\circ}$ & $4^{\circ}$ & $2^{\circ}$ & $2^{\circ}$ & $6^{\circ}$ \\
\hline & Bélgica & $12^{\circ}$ & $9^{\circ}$ & $7^{\circ}$ & $3^{\circ}$ & $6^{\circ}$ & $11^{\circ}$ & $12^{\circ}$ & $8^{\circ}$ & $8^{\circ}$ & $14^{\circ}$ \\
\hline & EUA & $14^{\circ}$ & $15^{\circ}$ & $9^{\circ}$ & $9^{\circ}$ & $10^{\circ}$ & 70 & $7^{\circ}$ & $4^{\circ}$ & $5^{\circ}$ & $8^{\circ}$ \\
\hline & China & $30^{\circ}$ & $27^{\circ}$ & $26^{\circ}$ & $28^{\circ}$ & $27^{\circ}$ & $30^{\circ}$ & $26^{\circ}$ & $26^{\circ}$ & $23^{\circ}$ & $23^{\circ}$ \\
\hline$\nabla$ & África do sul & $24^{\circ}$ & $28^{\circ}$ & $23^{\circ}$ & $34^{\circ}$ & $20^{\circ}$ & $26^{\circ}$ & $29^{\circ}$ & $19^{\circ}$ & $38^{\circ}$ & $21^{\circ}$ \\
\hline 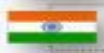 & índia & $39^{\circ}$ & $47^{\circ}$ & $46^{\circ}$ & $54^{\circ}$ & $35^{\circ}$ & $42^{\circ}$ & $47^{\circ}$ & $55^{\circ}$ & $58^{\circ}$ & $36^{\circ}$ \\
\hline 2 & Brasil & $61^{\circ}$ & $41^{\circ}$ & $45^{\circ}$ & $65^{\circ}$ & $55^{\circ}$ & $49^{\circ}$ & $37^{\circ}$ & $45^{\circ}$ & $54^{\circ}$ & $47^{\circ}$ \\
\hline & Rússia & $99^{\circ}$ & $94^{\circ}$ & $95^{\circ}$ & $90^{\circ}$ & $99^{\circ}$ & $93^{\circ}$ & $83^{\circ}$ & $96^{\circ}$ & $77^{\circ}$ & $94^{\circ}$ \\
\hline
\end{tabular}


Em comparação na infraestrutura de transporte da carga nacional, com o maior produtor de celulose do mundo, fazendo um cálculo simples entre a logística brasileira com a norte americana, sendo investido um valor igualitário à dos Estados Unidos em cada modal no Brasil, o mesmo economizaria cerca de $\mathrm{R} \$ 113$ bilhões, ou seja, 37\% dos custos com transporte de carga no Brasil. Um grande fator que contribui para essa diferença absurda do Brasil em comparação aos outros países, principalmente em relação aos Estados Unidos, é que passado mais de três décadas, o país ainda mantém uma infraestrutura para o transporte de carga com poucas mudanças em comparação ao que se tinha na década de 80 , se mantendo como um país carente em infraestrutura, de acordo com o Conselho Nacional da Indústria (CNI) através da nova versão do Mapa Estratégico da Indústria 2018-2022, demonstrada na figura 2 abaixo, a atual posição do Brasil nos modais.

Figura 2 - Posição do Brasil nos componentes de infraestrutura entre 137 países

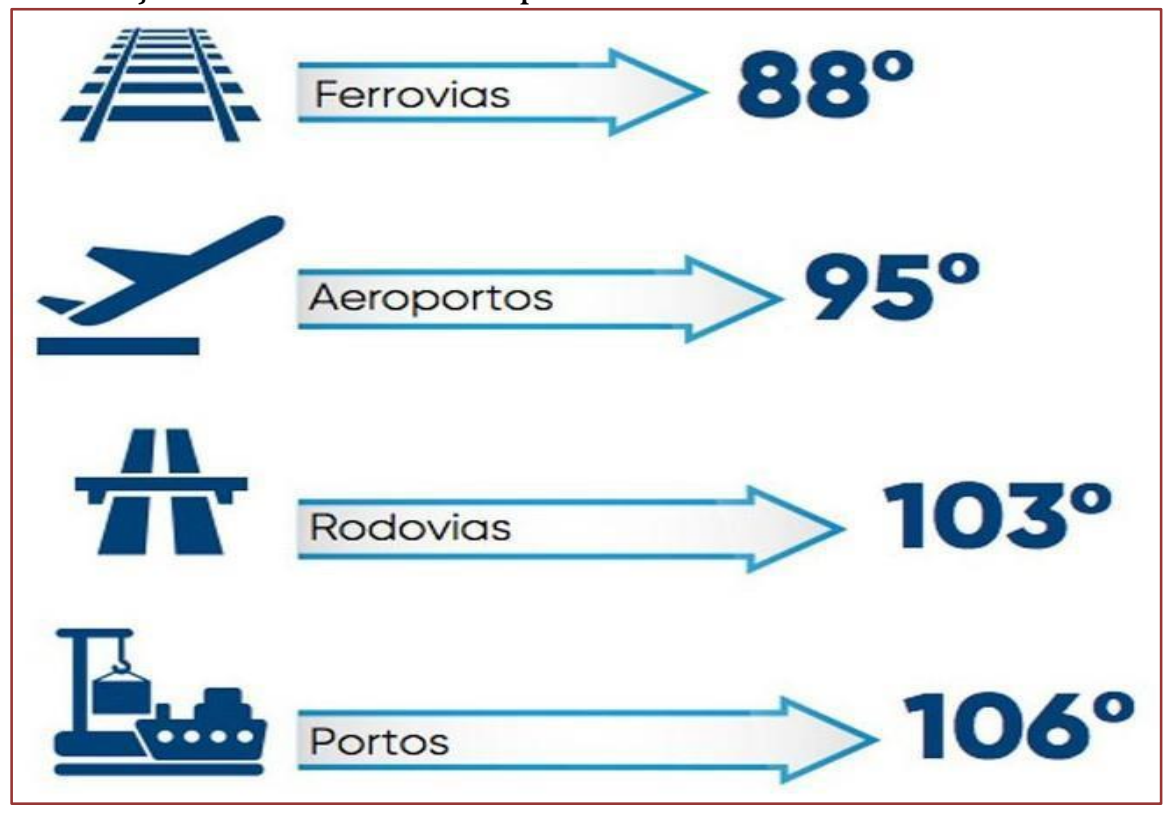

Fonte: WEF (2017)

Nos dias atuais, cada vez mais as empresas estão diminuindo a dependência do modal rodoviário, mesmo sendo predominante, é um transporte caro e mais poluente. Duas das maiores empresas produtoras de celulose estão com projetos inovadores em relação a logística.

Na Eldorado Brasil houve uma mudança estratégica no transporte de celulose até o Porto de Santos. Conforme a figura 3 abaixo, o transporte se inicia na fábrica em Três Lagoas (MS) onde a celulose é transportada através do modal rodoviário e de lá segue para o Porto de Santos pelo modal ferroviário. Lá as cargas são colocadas em vagões que seguem até o cais santista, com essa mudança é elimidada aproximadamente 25 mil viagens de caminhão em cada ano das rodovias, sem contar o ganho ambiental e a geração de empregos, mas pelos gargalos logísticos ferroviário em que o Brasil se encontra, uma parte da exportação da Eldorado Brasil não é atendida pelo modal ferrroviário, assim sendo utilizado o modal rodoviário da fábrica da empresa até o terminal da Eldorado/Rishis, localizado em Outerinhos, em Santos. 
Figura 3 - Logística da celulose da fábrica da Eldorado até o Porto de Santos

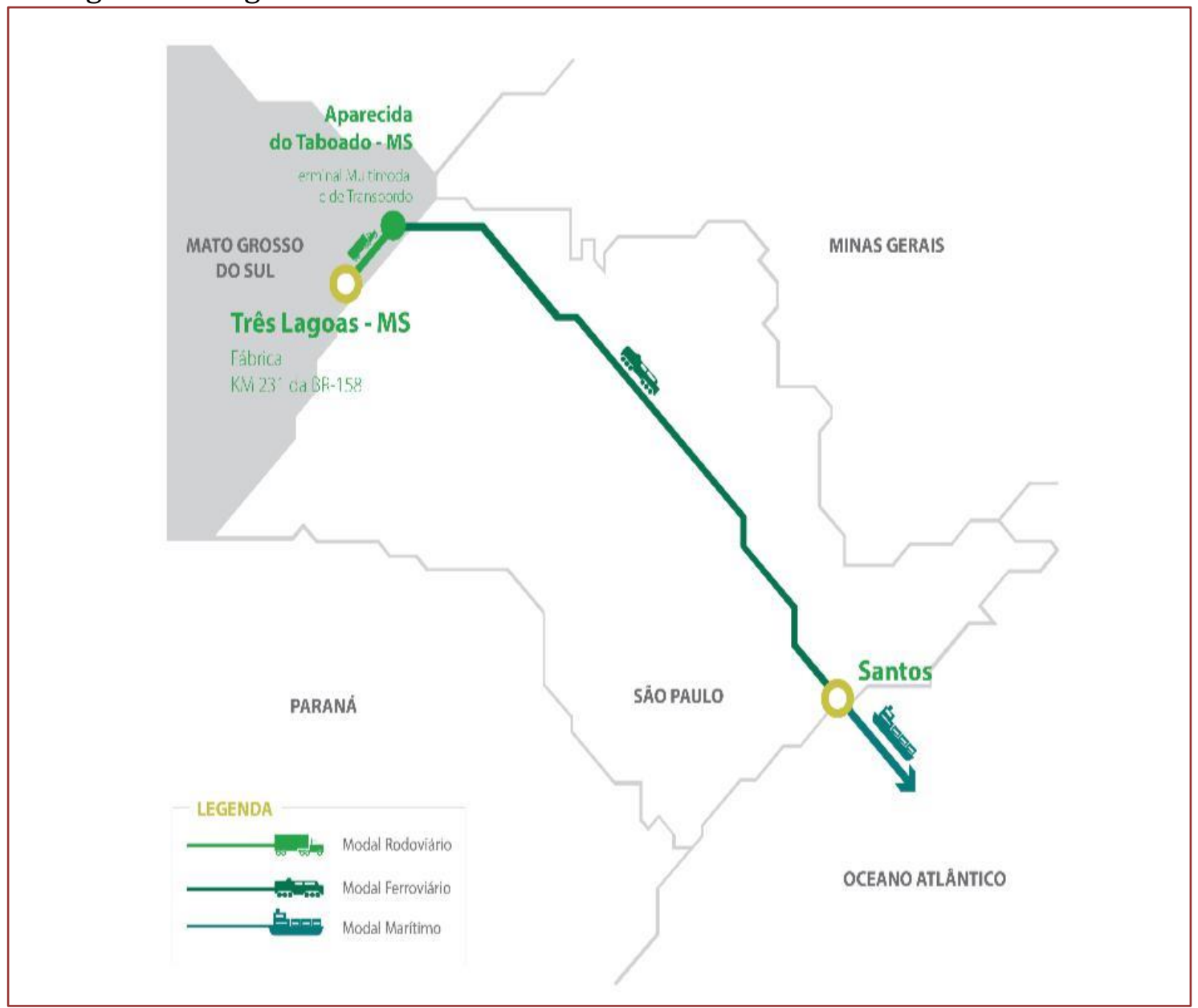

Fonte: Eldorado Brasil (2020)

Com uma parceria entre o Terminal da DP World Santos, localizado na margem esquerda do Porto de Santos e a Suzano que é considerada a maior produtora de celulose de eucalipto do mundo, com um investimento de $\mathrm{R} \$ 700$ milhões e com a geração de mais de 1.200 empregos diretos, foi formado o Projeto Vertere, que consiste numa implantação de novas instalações para recebimento, armazenagem e exportação de celulose. 0 armazém possui $35 \mathrm{mil} \mathrm{m}^{2}$, com capacidade estática de armazenagem de 170 mil toneladas de celulose. 0 recebimento dos fardos de celulose será $100 \%$ pelo modal ferroviário, nesse acesso foi criado uma pera ferroviária, que é formado por um pátio com sua forma circular que disponibiliza todo o transbordo da carga sem a necessidade de desmembramento do trem assim podendo receber até dois trens simultâneos com $1.500 \mathrm{~m}$ de extensão cada composição. Pensando na segurança, a operação é realizada através de pontes rolantes, mais segura, dinâmica e eficiente. Com uma extensão de 446 metros de cais, pode ocorrer a atracação de até dois navios simultâneamente. 


\section{INDICADORES E RESULTADOS DA EXPORTAÇÃO DA CELULOSE PELO PORTO DE SANTOS}

Sem dúvida alguma a exportação de celulose está no caminho certo no cenário mundial trazendo inúmeros investimentos para todo o Brasil. E se tratando do Porto de Santos cada vez mais ganhando destaque no volume exportado da celulose, vai se gerando uma expectativa em que o mercado continue em uma crescente nos próximos anos para a região. Conforme a figura 4 abaixo, de acordo com os dados obtidos pela antiga Companhia Docas de Santos ( CODESP) que passou a se chamar Santos Port Authority (SPA), a relação entre o mês de junho/2017 e o mesmo mês em 2018, a celulose teve um aumento expressivo nas exportações, passando de 273.773 t para 406.791 t, um aumento de $133.019 \mathrm{t}$, cerca de $48,6 \%$ a mais no envio de celulose ao exterior.

\begin{tabular}{|c|c|c|c|c|}
\hline \multicolumn{5}{|c|}{ VARIAÇÕES MAIS EXPRESSIVAS NOS EMBARQUES } \\
\hline & JUN/17 & JUN/18 & VAR. & VAR. $\%$ \\
\hline SOJA EM GRÃOS A GRANEL & 2.148 .380 & 2.711 .161 & 562.781 & 26,2 \\
\hline CELULOSE & 273.773 & 406.791 & 133.019 & 48,6 \\
\hline $\begin{array}{l}\text { SUCOS CÍTRICOS EM } \\
\text { CONTÊINERES }\end{array}$ & 108.201 & 181.989 & 73.788 & 68,2 \\
\hline ÓLEO COMBUSTÍVEL & 139.764 & 148.092 & 8.328 & 6,0 \\
\hline $\begin{array}{l}\text { SOJA EM GRÃOS EM } \\
\text { CONTÊINERES }\end{array}$ & 1.861 & 8.615 & 6.754 & 362,9 \\
\hline ÓLEO DIESEL E GASÓLEO & 159.221 & 164.790 & 5.569 & 3,5 \\
\hline GASOLINA & 108.442 & 112.555 & 4.113 & 3,8 \\
\hline SUCOS CÍTRICOS A GRANEL & 13.886 & 16.881 & 2.995 & 21,6 \\
\hline AÇÚCAR EM SACOS & 0 & 0 & 0 & \\
\hline
\end{tabular}

Fonte: Codesp / SPA (2018)

Com o aumento expressivo de celulose pelo Porto de Santos, além do governo federal, muitas empresas do setor devem direcionar parte dos investimentos na regiao, gerando um grande aumento em suas receitas.

A empregabilidade nas movimentações de celulose é $20 \%$ maior do que a movimentação de contêineres. Ao longo dos anos, a propensão é de que os terminais portuários serão gerenciados por donos de navios ou de carga, como o que já está acontecendo no mundo inteiro onde os grandes armadores estão adquirindo os terminais, dando exemplo do Terminal da Coopersucar na Margem Direita, que é operado por tradings no controle dos terminais graneleiros.

No dia 28 de Julho de 2020 foi aprovado pelo Ministério da Infraestrutura (Minfra) o novo Plano de Desenvolvimento e Zoneamento (PDZ) do porto de Santos com a primeira atualização em 15 anos do planejamento do maior porto da América Latina. Com essa aprovação será permitido a modernização do Porto de Santos, com a estratégica de ocupação de áreas públicas pelo decorrer dos próximos 20 anos. Em relação as áreas destinadas para a operação de celulose no Porto de Santos, conforme a figura 5 abaixo, terá sua capacidade expandida dos atuais 7,1 milhões de toneladas para 10,5 milhões de toneladas, um ganho de $48 \%$ total.

Conforme a SPA (2020), estima-se uma geração de mais de 50 mil empregos nos próximos 5 anos, contando desse total, 19,3 mil diretos, 9 mil indiretos e os restantes 
29,7 mil efeito-renda. Para o cálculo desses números, a Companhia recorreu a metodologia do Banco Nacional de Desenvolvimento Econômico e Social (BNDES), adequada pela Empresa de Planejamento e Logística (ELP), cujos resultados representam o total de empregos criados ao decorrer de todo o periodo de execução dos projetos. Com todo esse planejamento e ampliação da capacidade e movimentação da celulose, o Porto de Santos ganhará em torno de 2,4 mil novos empregos diretos nos terminais, um acréscimo de 15\% em relação aos números atuais, ampliando de 16,1 mil trabalhadores para 18,5 mil - nesse cálculo estão somados os trabalhadores vinculados aos terminais portuários e avulsos escalados pelo Orgão Gestor de Mão de Obra (OGMO).

Figura - 5 Áreas destinadas para a operação de Celulose com o novo PDZ

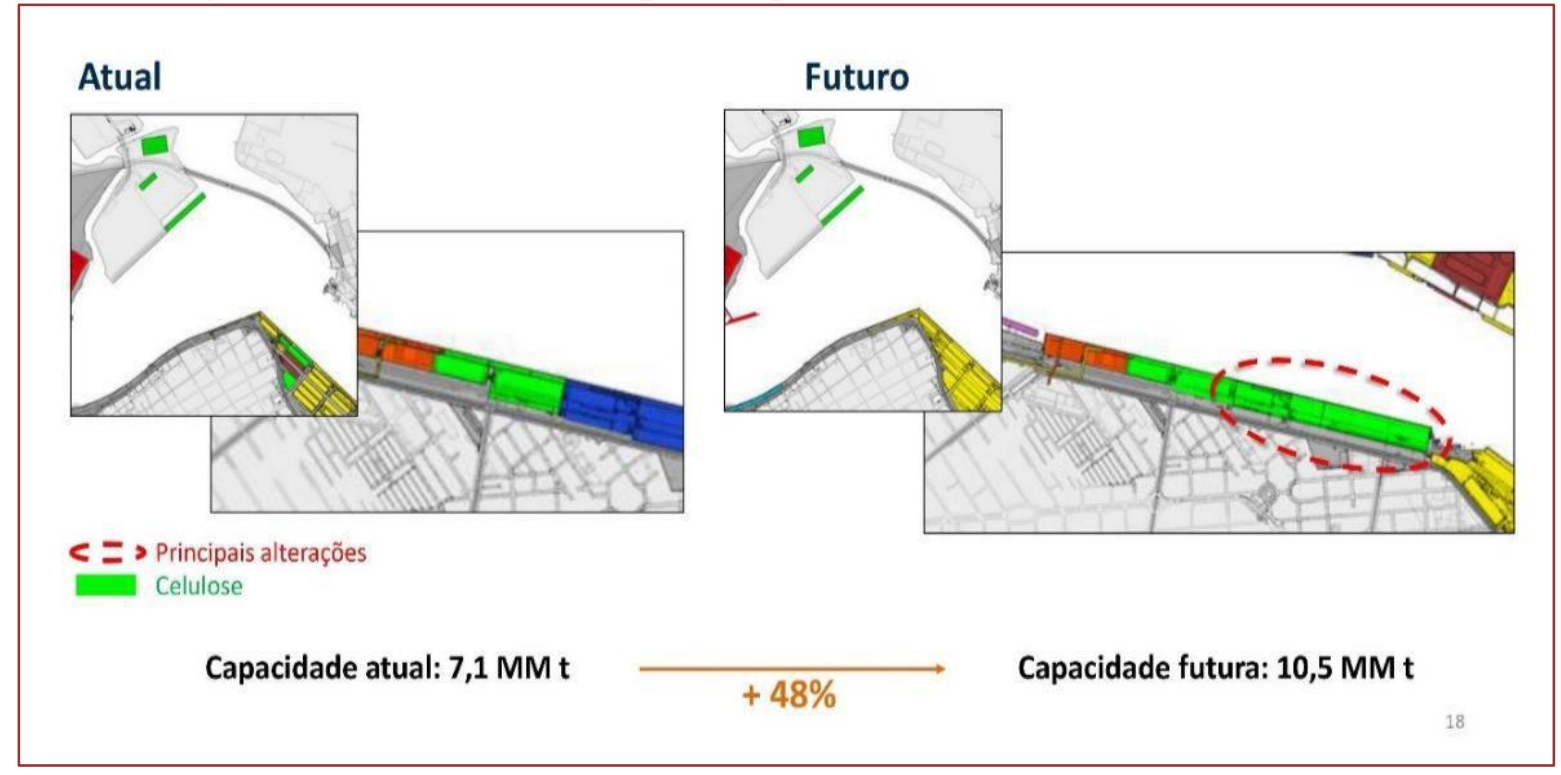

Conforme Biral (2020), o PDZ foi projetado para propiciar um futuro melhor ao Porto de Santos, ganhando eficiência e produtividade nas operações portuárias. Significa um grande marco para a modernização de todo complexo, aumento na criação de empregos e renda em toda a baixada santista. É de grande importancia mencionar que esse trabalho obteve êxito com grandes esforços entre Santos Port Authority (SPA), Ministério da Infraestrutura (MINFRA) e com o Planalto Central, com esse novo PDZ toda cadeia logística é beneficiada, não somente para o Porto de Santos, mas para toda a logística brasileira em si que se fortalece para o embarque e desembarque de produtos pelo Porto de Santos.

Um fator importante conforme as diretrizes do governo federal é investimentos expressivos no modal ferroviário, que é o mais indicado para o trasnporte de celulose, com um aumento desse modal para o Porto de Santos, ampliando as linhas ferroviárias dos atuais $33 \%$ para $40 \%$. Com esse novo PDZ, um dos objetivos é tornar o Porto de Santos no maior corredor de exportação de celulose do mundo.

No dia 28 de Agosto de 2020 aconteceu o leilão de duas áreas (STS14 e STS14A) no Porto de Santos no valor de R 505 milhões para a movimentação de celulose, com concessão de 25 anos. As empresas vencedoras foram a Eldorado Celulose que já conta com um Terminal de Celulose Eldorado/Rishis na região de Outerinhos, em Santos arrematou a STS14 por R\$ 250 milhões e a outra empresa foi a Bracell Celulos que arrematou a STS14A por R 255 milhões. Com esses dois novos terminais de celulose, Santos iniciará a lógica de clusterização de áreas por tipo de carga permitindo assim uma maior produtividade da operação, que consta nas diretrizes do Plano de 
Desenvolvimento de Zoneamento (PDZ) com um grande destaque para o escoamento $100 \%$ ferroviário nos acessos aos terminais, gerando uma redução de custos com operações mais limpas (BIRAL,2020). Conforme a figura 6 abaixo, é demonstrada toda a projeção para as duas novas áreas leiloadas com o aumento de demanda/capacidade, a utilização de mais berços para atracação de navios, novos armazéns para o atendimento da demanda em curto prazo, aumento da utilização do modal ferroviário saindo de $51 \%$ para $90 \%$ em curto/médio prazo.

Figura 6 - Áreas leiloadas no Porto de Santos

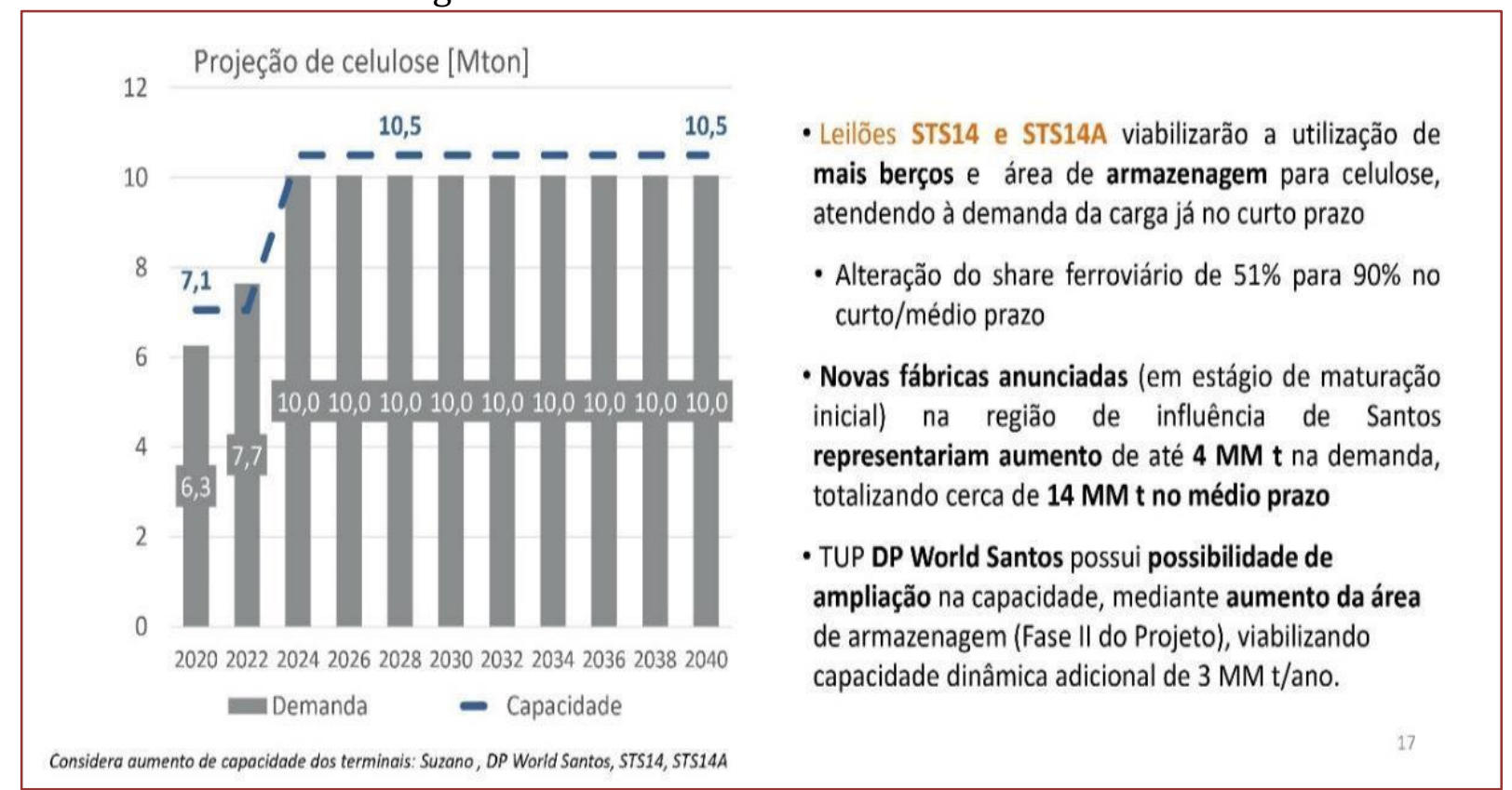

Fonte: SPA (2020)

\section{RESULTADOS E DISCUSSÃO}

Com base em estudos e pesquisas bibliográficas em relação ao desempenho e resultados obtidos em todo o processo de exportação de celulose, o Brasil é beneficiado pela sua posição geográfica no hemisfério sul, tornando indiscutivelmente o país no maior exportador mundial de celulose devido ao seu clima tropical favorável, foi verificado que o país tem uma grande deficiência em toda sua cadeia logística desde a sua produção até o embarque, tendo a necessidade de maiores investimentos na infraestrutura nos modais de transporte, uma nova política do governo e de parcerias com empresas privadas do setor por uma busca na redução dos inúmeros encargos tributários assim aumentando a competitividade em relação a concorrência internacional utilizando uma maior fatia do PIB em comparação a outros países e mais especificamente no processo logístico da celulose um maior investimento em tecnologias para o modal ferroviário sendo o mais adequado e eficiente.

\section{CONSIDERAÇÕES FINAIS}

Esta pesquisa se propôs, como objetivo geral, demonstrar o cenário atual do Brasil com a disparada na produção e exportação da celulose com diversos investimentos nessa commoditie gerando um grande destaque na balança comercial brasileira. Por outro lado, foi identificado necessidades em sua cadeia logística e em toda a infraestrutura 
utilizada nesse segmento, como houve um aumento da produção, a infraestrutura não acompanhou na mesma proporção. Por outro lado, mesmo com uma melhoria em toda a cadeia produtiva e logística desde a produção até a sua exportação, é necessário uma reforma para a redução da carga tributária do país para se alcançar uma maior competitividade em comparação a concorrência internacional. É de grande importância uma adequação logística da celulose eliminando os gargalos ferroviários com a diminuição do modal rodoviário e ampliando a malha ferroviária, possibilitando um maior volume de carga transportada e assim obtendo ganhos ambientais, redução do tráfego de caminhões nas rodovias e geração de empregos e não somente para o Porto de Santos, mas para toda a cadeia logística brasileira. Atualmente o cenário brasileiro vai demonstrando mudanças satisfatórias na operação logística de suas mercadorias, como foi mencionado nesse artigo, empresas como a Eldorado Brasil e a parceria entre a Suzano e DP World, já utilizam em sua movimentação quase 100\% do modal ferroviário para o escoamento da celulose. Após a nova aprovação do PDZ para o Porto de Santos, com projetos direcionados a armazenagem e embarque da celulose utilizando $100 \%$ o modal ferroviário, fica mais evidente que o Brasil está caminhando para se tornar o maior corredor de exportação de celulose do mundo.

\section{REFERÊNCIAS}

[1] ABRACOMEX. Brasil maior exportador mundial de celulose. Disponível em: <https://www.abracomex.org/brasil-maior-exportador-mundial-de-celulose>. Acesso em: 25 ago. 2020.

[2] AGENCIA NACIONAL DE TRANSPORTE AQUAVIÁRIO -ANTAQ. ANTAQ leiloa duas áreas no Porto de Santos por R 505 milhões. Disponível em:

<http://portal.antaq.gov.br/index.php/2020/08/28/antaq-leiloa-duas-areas-no-porto-desantos-por-r-505-milhoes/>. Acesso em: 2 set. 2020.

[3] ASSOCIAÇÃO BRASILEIRA DA INFRAESTRUTURA E INDÚSTRIAS DE BASE - ABDIB. Brasil precisa investir 4,31\% do PIB em infraestrutura. Disponível em:

<https://www.abdib.org.br/2020/02/11/investimento-infraestrutura/>. Acesso em: 30 ago. 2020.

[4] BIRAL, F. Após 15 anos, Porto de Santos aprova novo PDZ . Disponível em: <http://www.portodesantos.com.br/press-releases/destaque/apos-15-anos-semplanejamento-porto-de-santos-aprova-novo-pdz/> . Acesso em: 3 set. 2020.

[5] ELDORADO BRASIL. Transporte com menor pegada de carbono. Disponível em: <http://www.eldoradobrasil.com.br/Tecnologia-e-Inovacao/Logistica-Integrada/Multimodalde-baixa-emissao>. Acesso em: 27 ago. 2020.

[6] FAZCOMEX. Exportação de Celulose. Disponível em: <https://www.fazcomex.com.br/blog/exportacao-de-celulose/>. Acesso em: 1 set. 2020.

[7] FLORESTAL REVISTA OPINIÕES. Logística na indústria de celulose. Disponível em: <https://florestal.revistaopinioes.com.br/revista/detalhes/25-logistica-na-industria-decelulose/>. Acesso em: 29 ago. 2020.

[8] ILOS. Custos logísticos no Brasil . Disponível em:

$<$ https://www.ilos.com.br/web/logistica-do-brasil-segundo-recente-estudo-do-bancomundial/>. Acesso em: 3 set. 2020.

[9] MADRUGA, V. O mercado brasileiro no cenário mundial de celulose. Disponível em: <https://florestal.revistaopinioes.com.br/revista/detalhes/6-o-mercado-brasileiro-no-cenariomundial-de-celul/>. Acesso em: 1 set. 2020. 
[10] NOTÍCIAS AGRÍCOLAS. Exportação de celulose deve aumentar, diz a Forest2Market do Brasil. Disponível em<https://www.noticiasagricolas.com.br/noticias/agronegocio/226687exportacao-de-celulose-deve-aumentar-diz-a-forest2market-do-brasil.html\#.X0vf4u-SmUk>. Acesso em: 30 ago. 2020.

[11] PORTO DE SANTOS. Análise do Movimento Físico do Porto de Santos Junho 2018. Disponível em: http://www.portodesantos.com.br/. Acesso em: 1 set. 2020.

[12] REVISTA MUNDO LOGÍSTICA. Eldorado Brasil muda estratégia e reduz 25 mil viagens rodoviárias. Disponível em: <https://revistamundologistica.com.br/noticias/eldorado-brasilmuda-estrategia-e-reduz-25-mil-viagens-rodoviarias>. Acesso em: 31 ago. 2020.

[13] SUMMITAGRO. Celulose brasileira: exportação em massa para o mundo. Disponível em: <https://summitagro.estadao.com.br/celulose-brasileira-exportacao-para-o-mundo/>. Acesso em: 26 ago. 2020.

[14] SUZANO. História da Celulose. Disponível em:<https://www.suzano.com.br/asuzano/historia>. Acesso em: 25 ago. 2020.

[15] VERRUCK,J.. MS respondeu por quase 30\% da exportação de celulose do Brasil em 2020. Disponível em: <http://www.caarapoonline.com.br/noticia/10246/ms-respondeu-por-quase30-da-exportacao-de-celulose-do-brasil-em-2020 >. Acesso em: 28 ago. 2020. 


\section{Capítulo 4}

\section{Exportações de algodão via Porto de Santos}

\section{Eduardo Santos do Nascimento}

\section{Sarah Silva de Oliveira}

Resumo: Todos os anos, uma média de 35 milhões de hectares de algodão é plantada em todo o mundo e o comércio mundial de algodão movimenta cerca de US \$ 12 bilhões anualmente e envolve mais de 350 milhões de pessoas em sua produção, desde fazendas a logística, descaroçamento, processamento e embalagem. Atualmente, o algodão é produzido por mais de 60 países e o Brasil se consolidou nos últimos anos entre os maiores produtores e exportadores de algodão do mundo. Diante das safras recordes ano após ano, o objetivo deste trabalho é analisar a cadeia produtiva do algodão no Brasil e a relevância do Porto de Santos na dinâmica de exportação desse produto, fazendo uma avaliação do cenário atual, bem como identificar possíveis gargalos e avaliar as perspectivas futuras. Em relação a metodologia utilizada no presente artigo, realizou-se uma pesquisa descritiva analítica baseada em artigos, revisões bibliográficas e publicações de órgãos especializados e como referência tomou-se como base as exportações via porto de Santos. Apesar da crescente demanda global e produção de algodão no Brasil a operação via porto de Santos ainda está longe de perder sua hegemonia na logística do algodão para outros portos do Brasil mas é importante se manter atento as mudanças de mercado e oportunidades de melhorias. E com o advento do Covid-19, é esperado um impacto no comércio mundial e que pode afetar diretamente a comercialização tanto do algodão quanto dos seus derivados e medidas preventivas podem ser tomadas para reduzir o impacto negativo neste setor.

Palavras-chave: Logística. Agronegócio. Cotonicultura. Covid-19. 


\section{INTRODUÇÃO}

O agronegócio, que contempla a produção agrícola e pecuária, pode ser considerado, o principal protagonista e impulsionador da economia nacional, segundo dados da Confederação da Agricultura e Pecuária do Brasil (CNA) o setor de agronegócios teve um crescimento de $3.81 \%$ em relação à 2018 e representou $21.4 \%$ do PIB (Produto Interno Bruto) de 2019 . Ainda de acordo com dados publicados pelo Ministério da Agricultura, Pecuária e Abastecimento (MAPA), estima-se que produção agrícola da safra 2018/19 passe de 236,7 milhões de toneladas para 300,1 milhões até 2028/29, representando um crescimento aproximado de 2,4\% ao ano.

Com desempenhos expressivos nos últimos anos, atualmente, o Brasil ocupa a terceira posição no ranking de maiores exportadores de produtos agrícolas do mundo, obtendo expressivos desempenhos no últimos anos e a produção de algodão, ou cotonicultura, tem um papel importante neste cenário. (JACTO, 2019). Mesmo dada a importância desse setor, um dos principais desafios ainda consiste na falta de infraestrutura portuária e uso massivo do modal rodoviário o que eleva os custos e impacta na competitividade do comércio exterior.

Sendo o Brasil um dos maiores exportadores de algodão, este estudo tem o objetivo analisar a cadeia produtiva do algodão no Brasil e a relevância do Porto de Santos na dinâmica de exportação desse produto, bem como identificar possíveis gargalos e avaliar as perspectivas futuras.

E com a pandemia do novo Covid-19, fez com o que diversos países trabalhassem para controlar o avanço do vírus, uma das medidas preventivas adotadas pelo Brasil foi a restrição de exportação de determinados produtos para o combate da Covid-19 por meio da Lei № 13.993, DE 23 DE ABRIL DE 2020 (FIESP, 2020). Até o momento, essas restrições no Brasil se limitam aos produtos considerados essenciais para o combate ao Covid-19 e com isso o país visa manter o maior número de recursos no seu território para que consiga atender com eficiência a grande demanda da área da saúde o que não é o caso do algodão mas ainda sim é esperado um impacto sob a exportação desse produto.

Ainda não se sabe se outros portos do Brasil poderiam concorrer com o porto de Santos na exportação do algodão, porém a fim de manter essa hegemonia e auxiliar na perspectivas de crescimento das safras e exportações de algodão desde da produção até a exportação é importante a análise da infraestrutura logística das operações hoje presentes no Brasil e a percepção em relação à redução de custos e consequente ganho de competitividade e impactos do Covid-19.

Os dados para este estudo foram coletados por meio de pesquisa descritiva analítica baseada em artigos, revisões bibliográficas, bem como de associações de produtores de algodão de órgãos governamentais. (GIL, 1999).

\section{EMBASAMENTO TEÓRICO}

Historicamente a literatura enfatiza o algodão como um dos mais antigos produtos explorados através da agricultura. A utilização da fibra de algodão é conhecido do homem desde os tempos mais remotos, sendo que os primeiros fragmentos de tecido datam mais de sete mil anos. Os árabes foram os responsáveis pela difusão do algodão pela Europa, porém antigas civilizações como os egípcios e os incas já exerciam a prática de cultivo e tecelagem dos fios (UNCTAD, 2005). 
A composição do fruto do algodão é dividida em sementes (52\%), fibras (40\%) e estruturas botânicas (8\%). As sementes podem ser dissociadas em óleo (15\%), fibras (3\%), proteínas (40\%) e tegumentos (42\%) (BELTRÃO, 1999; GARCIA-LORCA e CARNERO). As fibras, por sua vez, são compostas por camadas de celulose e são as estruturas principais do produto econômico produzido pelo algodoeiro. Dentre os principais usos da fibra de algodão, incluem-se móveis, aplicações médicas, na indústria automobilística e em várias outras indústrias. No entanto, o principal consumo é para fiação destinada à indústria têxtil, que absorve aproximadamente $60 \%$ da produção mundial de fibra algodão (IICA/MAPA/SPA, 2007).

A produção de algodão exige solos férteis e são necessários dias predominantemente ensolarados com temperaturas médias entre $22^{\circ} \mathrm{C}$ e $30^{\circ} \mathrm{C}$. $\mathrm{O}$ cultivo é manual em países como Índia, Paquistão e China, ou mecânico como nos Estados Unidos e Brasil (BELTRÃO, 1999; CIA et al., 1999).

Em relação a colheita, ainda no campo, o algodão é prensado em fardos e são importantes alguns cuidados a fim de evitar a contaminação com terra e outras impurezas. Outra vantagem do enfardamento é evitar quebras nas extremidades durante seu manuseio e transporte e é de extrema importância que os fardos sejam armazenados atentando-se para sua proteção quanto à umidade, poeira e demais contaminantes (EMBRAPA, 2005).

Conforme a Associação Brasileira dos Produtores de Algodão (ABRAPA, 2020) o Brasil tem figurado também entre os maiores exportadores mundiais e cenário interno é promissor e depois de ultrapassar a Índia no ano passado, tornando-se o segundo maior exportador de algodão em pluma do mundo, acredita-se que o Brasil está no caminho para ser o líder global nos embarques do produto.

E a previsão da Associação Nacional dos Exportadores de Algodão (ANEA) é que isso aconteça em um prazo de cinco anos ultrapassando assim o Estados Unidos, atualmente o maior exportador de algodão do mundo segundo a Bolsa Brasileira de Mercadorias (BBM,2020). A BBM (2020, p. 2) afirma que:

A produção da safra 2019/2020 registra um recorde de 2,9 milhões de toneladas, superando o recente recorde da temporada anterior. A produção brasileira é a quarta maior do mundo. 0 principal gargalo do Brasil, que sempre foi a questão logística, vem melhorando nos últimos anos de acordo com a categoria e, com isso, o país tem avançado no contexto de transportar o algodão de estados como Mato Grosso e Bahia até os portos brasileiros.

De acordo com o Ministério da Agricultura, Pecuária e Abastecimento (MAPA, 2019) a produção de algodão Brasileira concentra-se especialmente nos estados de Mato Grosso e Bahia, que respondem em $2018 / 19$ por $88,3 \%$ da produção do país. Mato Grosso tem a liderança com $66,2 \%$ da produção nacional, vindo a seguir o estado da Bahia com 22,1\% da produção brasileira conforme apresenta-se na Figura 1. 
Figura 1. Produção Nacional do Algodão

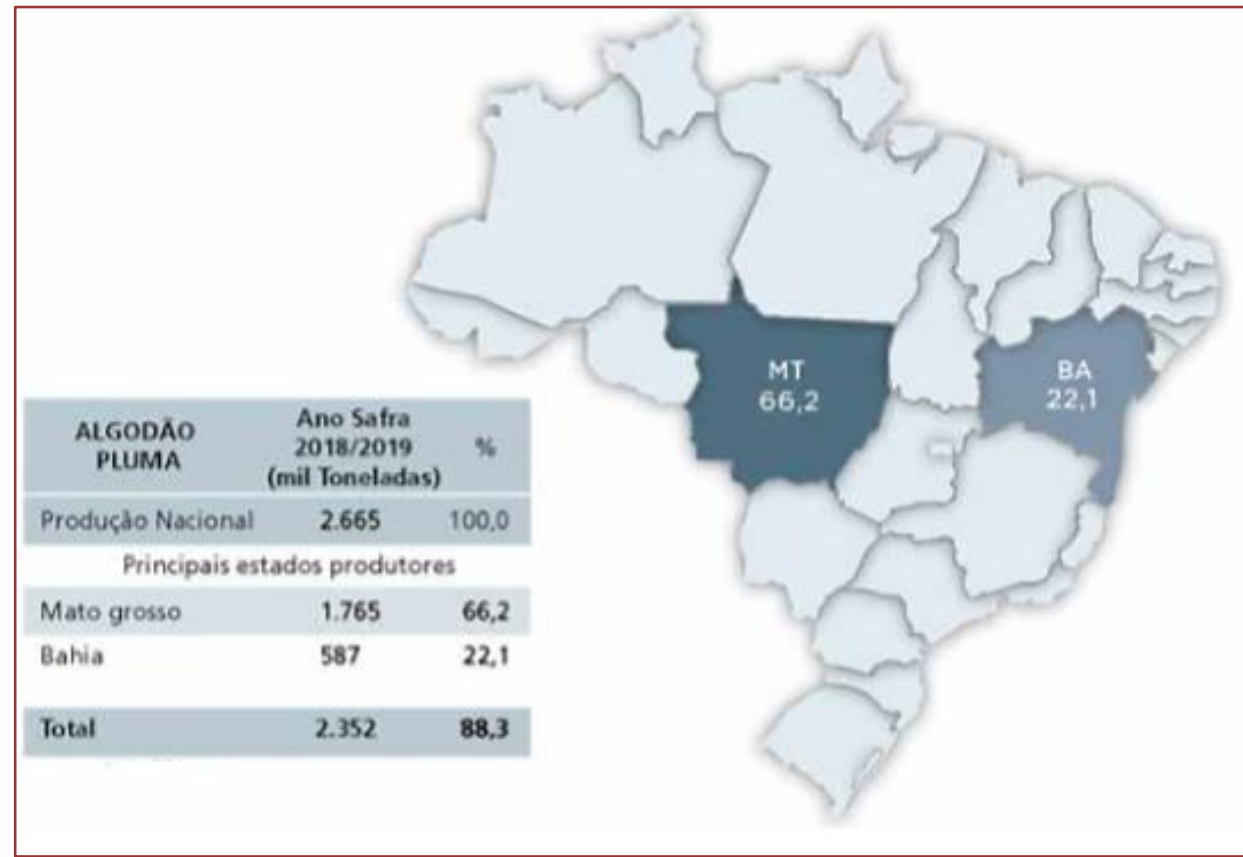

Fonte: MAPA (2019)

E dentre os principais destinos da exportação de algodão, de acordo com a USDA(2019) e conforme apresentado no Gráfico 1, a China expressivamente se tornou nos últimos dois anos o principal importador do algodão brasileiro.

Gráfico 1 - Destino da exportação de algodão brasileira em TON

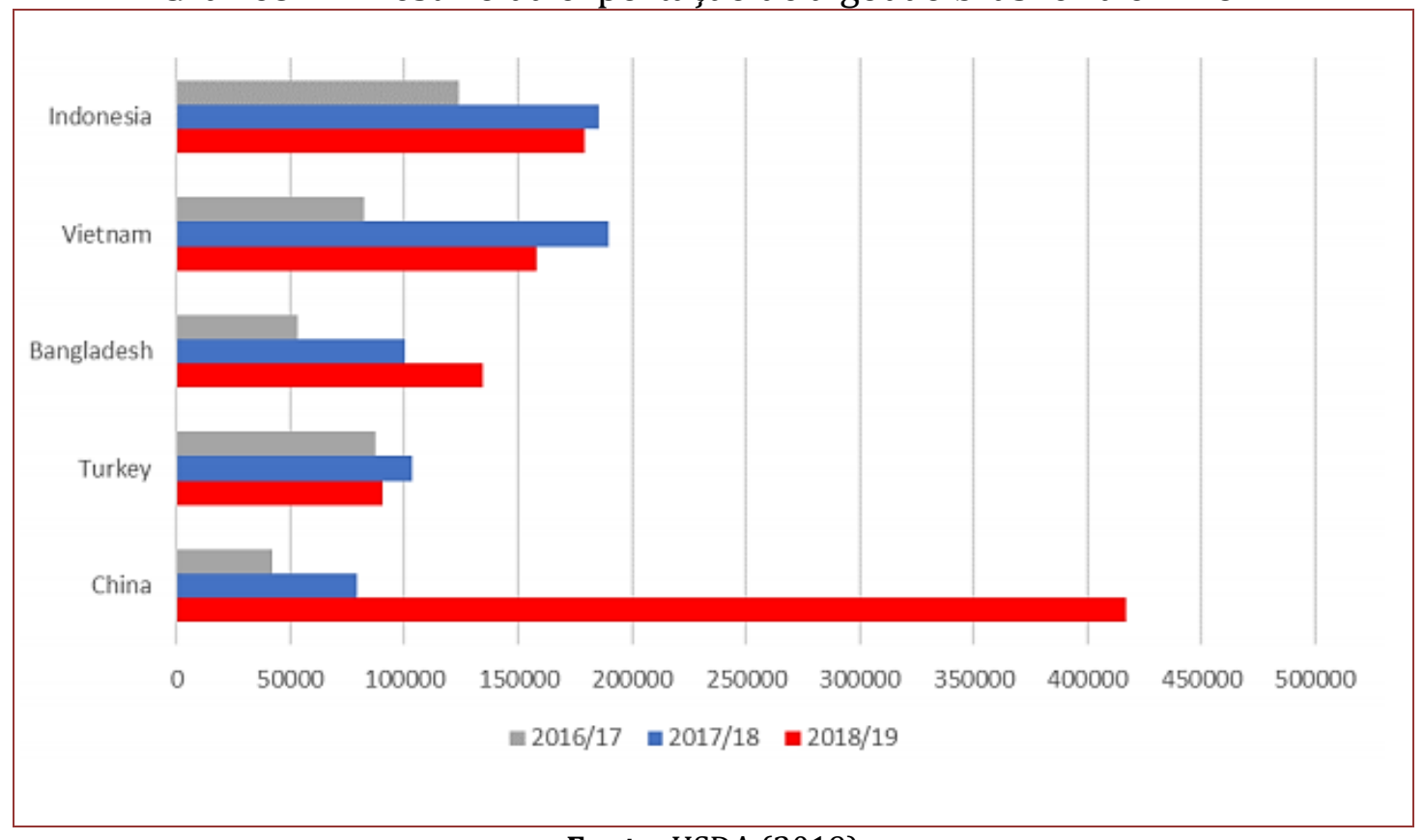

Fonte: USDA (2019) 


\section{CADEIA LOGÍSTICA DO ALGODÃO}

Uma das regiões detentoras de maior volume da produção de algodão é o Mato Grosso, que inclusive bateu recordes no ano de 2019, atingindo 1,11 milhão de hectares plantados (uma alta de 40,71\% em relação ao ano anterior) de acordo com o Instituto Mato-grossense de Economia Agropecuária (Imã) (2019). Grande parte de toda essa produção escoa para o porto de Santos, através de rotas ferroviárias ou rodoviárias, enfrentando diversos gargalos logísticos.

A acessibilidade é certamente um dos pontos mais fortes do porto de Santos, o maior porto da América Latina possui rotas regulares para os potenciais importadores de algodão. Devido ao acesso e localização próxima a operadoras de ferrovia, rotas rodoviárias, e a armazéns de estufagem torna o complexo o mais completo. Os armazéns de estufagem, por sua vez, possui as melhores práticas e tecnologias para o processo como é o exemplo da Brado. A empresa de logística possui um sistema capaz de estufar um contêiner de 40 pés com sua capacidade máxima de 25 toneladas, em apenas 20 minutos. Este sistema está operativo nos terminais em Rondonópolis. Após a estufagem, a unidade é transferida via modal ferroviário para o porto de Santos. (GLOBO RURAL, 2018).

\subsection{DESAFIOS DA CADEIA LOGÍSTICA NO PORTO DE SANTOS}

O produto proveniente do Mato Grosso percorre longas distâncias, entre Rondonópolis, no Mato Grosso, e o Porto de Santos, por exemplo, são mais de 1.400 quilômetros (ABRAPA, 2012). Além disso, na plantação do algodão são utilizados insumos como os fertilizantes, provenientes de importação, que traçam esta mesma rota e encarecem os custos de produção. A otimização da cadeia de distribuição destes insumos e do produto a ser exportado é imprescindível para diminuir o custo do algodão nacional.

O relatório divulgado pela a ANEA - Associação Nacional dos Exportadores de Algodão, afirma que em 2019 o porto de Santos foi responsável pelo embarque de $97 \%$ da exportação de algodão. De acordo com a associação, em outubro de 2019 o volume exportado ultrapassou $1 \mathrm{mi}$ de toneladas e os atrasos para embarque chegaram a atingir até duas semanas, deixando em evidência a falta de estrutura do porto em atender altos picos de demanda, encarecendo o custo logístico e fazendo com que o algodão brasileiro perdesse competitividade junto ao mercado internacional.

Outro gargalo é o excesso de burocracia. 0 processo de despacho aduaneiro é ineficiente e agrava-se entre setembro e dezembro, meses de pico das exportações (Figura 2). Durante este período é comum problemas como: aumento de estadia dos produtos nos terminais devido à falta de espaço para armazenagem, atrasos no carregamento, congestionamentos na área rodoviária, etc. 
Figura 2 - Exportações Brasileiras de Algodão em 2019

\begin{tabular}{|l|r|r|}
\hline \multirow{2}{*}{ MESES } & \multicolumn{2}{|c|}{ Total Geral Aculmulado } \\
\cline { 2 - 3 } & USS & \multicolumn{1}{c|}{ Toneladas } \\
\hline JANEIRO & 198.544 .020 & 115.194 \\
\hline FEVEREIRO & 159.307 .291 & 93.511 \\
\hline MARÇO & 176.219 .087 & 104.262 \\
\hline ABRIL & 125.117 .433 & 73.499 \\
\hline MAIO & 141.062 .708 & 82.899 \\
\hline JUNHO & 108.293 .364 & 64.885 \\
\hline ACUMULADO 1 ${ }^{\circ}$ SEMESTRE & 908.543 .903 & 534.249 \\
\hline JULHO & 74.442 .149 & 46.979 \\
\hline AGOSTO & 72.186 .248 & 45.288 \\
\hline SETEMBRO & 264.350 .879 & 164.634 \\
\hline OUTUBRO & 464.660 .869 & 288.149 \\
\hline NOVEMBRO & 412.360 .065 & 256.499 \\
\hline DEZEMBRO & 443.833 .791 & 277.872 \\
\hline ACUMULADO 2 ${ }^{\circ}$ SEMESTRE & 1.731 .834 .001 & 1.079 .421 \\
\hline TOTAL ANO & 2.640 .377 .904 & 1.613 .670 \\
\hline
\end{tabular}

Fonte: ANEA (2019)

Enquanto os gargalos de infraestrutura do porto de Santos não são solucionados completamente, o direcionamento de parte da produção para portos alternativos, ou seja, a descentralização da demanda, aparenta ser uma das melhores propostas.

Em 2018 consolidou-se uma rota alternativa ao porto de Santos, a utilização do porto de Salvador para exportações com destino a Ásia, Oriente Médio e Oceania (GLOBO RURAL, 2018). 0 porto de Salvador fica aproximadamente 900 quilômetros de distância das áreas de produção do algodão no estado de Salvador, contra 1700 quilômetros entre a região e o porto de Santos. Atualmente o porto de Aratu ocupa a segunda posição no ranking de exportação por porto de embarque (Figura 3).

Figura 3: Exportações brasileiras de algodão por porto de embarque em 2019

\begin{tabular}{|c|l|r|r|}
\hline \multicolumn{1}{|c|}{ PORTO / FRONTEIRA } & \multicolumn{1}{|c|}{ USS FOB } & \multicolumn{1}{c|}{ VOLUME (TON) } \\
\hline MANESES & & 2.571 .427 .544 & 1.567 .307 \\
\hline & SANTOS - DEZEMBRO & 27.378 .223 & 20.272 \\
\hline & ARATU & 27.040 .340 & 17.568 \\
\hline & PARANAGUÁ & 11.086 .823 & 1.588 .385 \\
\hline & ITACOATIARA & 842.710 & 928 \\
\hline & SÃO FRANCISCO DO SUL & 709.543 & 530 \\
\hline & ALF - CORUMBÁ & 277.562 & 462 \\
\hline & ALF - FOZ DO IGUAÇU & 26.772 & 159 \\
\hline & ITAGUAI & 2 & 8 \\
\hline & PORTO DE SUAPE & & 0,002 \\
\hline & AEROPORTO INTERNACIONAL DE SAO PAULO/GUARULHOS & $\mathbf{2}$ & $\mathbf{1 . 6 1 3 . 6 7 0}$ \\
\hline
\end{tabular}

Fonte: ANEA (2019)

Para aumentar sua participação junto ao mercado de exportação do produto, o Terminal de Contêineres de Paranaguá (TCP), também tem investido em alternativas logísticas (operações dentro do terminal ou em armazéns próximos), aumentando sua capacidade de estufagem e oferecendo custos competitivos ao mercado (PORTOS E NAVIOS, 2019). As perspectivas para o ano de 2020 são positivas para aumento de volume exportado pelo TCP, contudo no ano de 2019 o porto foi responsável por uma fatia referente a apenas $1 \%$. 


\section{PERSPECTIVAS PARA O ALGODÃO PÓS O COVID-19}

No início da pandemia em abril o algodão bateu recorde de movimentação e no primeiro trimestre do ano foi possível apontar uma alta de 82,8\% no volume de exportações de algodão (COMEX DO BRASIL,2020). Estes números ainda não indicavam impactos do Covid-19 sobre as exportações. No mês de abril, durante uma web conferência organizada pela ABRAPA e a ANEA, foram discutidas as perspectivas para o setor. De acordo com Marcos Rubin, convidado do evento e sócio-diretor da Agroconsult, o mercado do algodão também será severamente afetado pela recessão da economia global. Antes da pandemia, as projeções para exportação global calculavam aproximadamente 9,4 milhões de toneladas. Até o final de Julho, o volume deve cair para 7,7 milhões de toneladas (ANEA,2020).

Apesar de nos últimos meses o Brasil ter tido vantagem na disputa com os Estados Unidos da América (EUA), por mercados como o da China e também pelo câmbio e desvalorização da moeda, a previsão é de que a partir de Julho o principal concorrente do país volte a retomada do mercado, tornando a disputa mais acirrada. A demanda global foi de 26 milhões de toneladas na safra de 2018/2019 e nesse período de recessão da economia global pode reduzir para aproximadamente 23 milhões de toneladas em 2019/2020 (NOTÍCIAS AGRÍCOLAS, 2020). De todo modo, os produtores e especialistas do setor mantem-se otimistas pelo menos para os próximos meses, devido a recuperação da China, principal importador desta commodity e ao fato de os produtores já terem comercializado aproximadamente $60 \%$ da próxima safra (BRASIL AGRO, 2020).

\section{RESULTADOS E DISCUSSÕES}

Em uma economia onde o agronegócio é o principal propulsor, e que o Brasil já ocupa as primeiras posição no ranking mundial na exportação de algodão, sendo que nos estados de Mato Grosso e Bahia que estão concentrada a maior parte da produção de algodão nacional.

Gráfico 2: Representatividade em TON e U\$ dos principais locais de exportação de algodão do Brasil

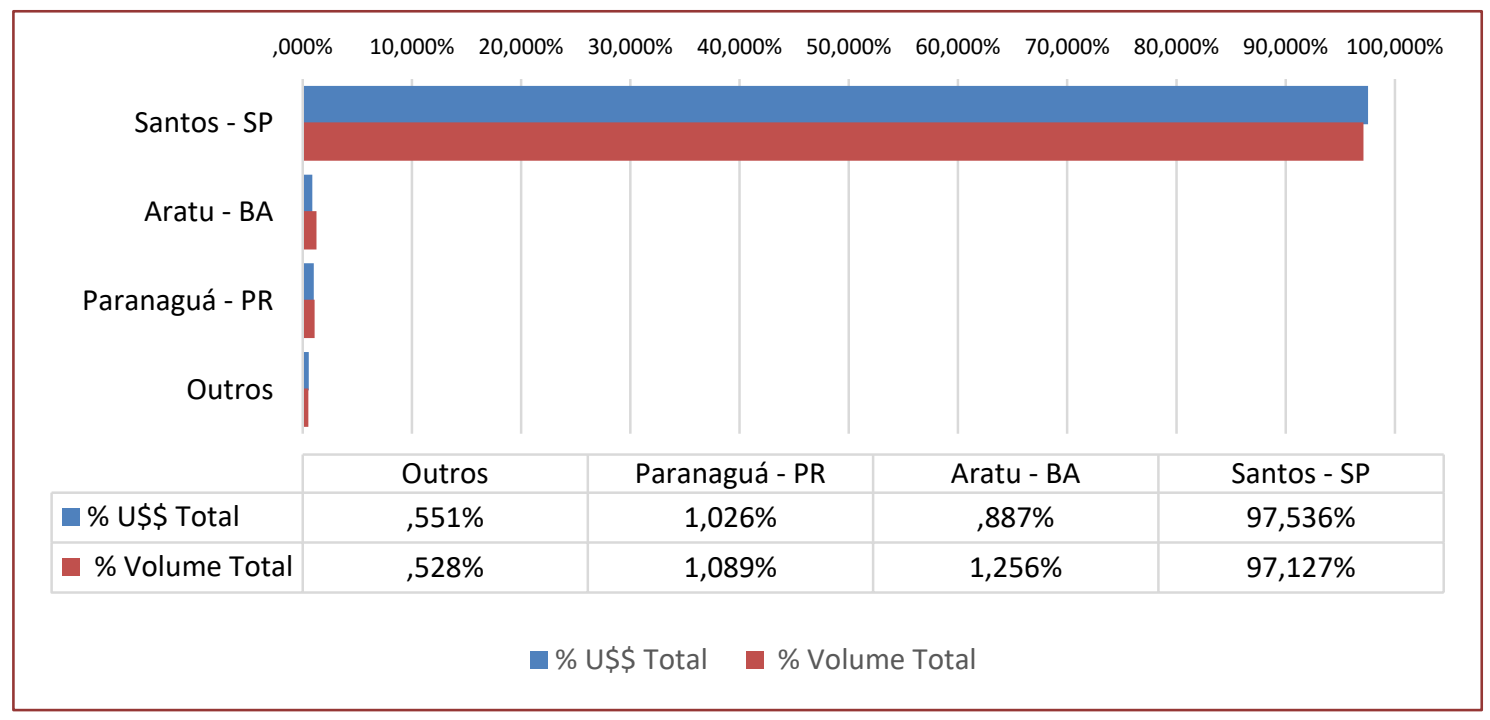

Fonte: Próprio Autores (2020) adaptado dos dados da ANEA(2019) 
Toda essa produção necessita de um sistema logístico eficaz para atender as demandas de exportação nos portos brasileiros, e mesmo com todos os gargalos de infraestrutura, o porto de Santos como podemos observar na Gráfico 2, é responsável pela movimentação de um pouco mais de $97 \%$ da exportação de algodão, esse domínio se dá pela proximidade entre o porto de Santos e os produtores de algodão localizados na região centro oeste do país e por possuir mais opções de serviços logísticos relacionados ao algodão, acesso beneficiado pelas rotas constantes rodoviárias e ferroviárias e mais opções de armazéns de estufagens.

Mesmo em proporção menor o Porto de Aratu na Bahia desponta em segundo lugar no volume de exportação e tem como vantagem a localização mais próxima ao segundo maior produtor nacional de algodão, a Bahia. Logo em seguida aparece o porto de Paranaguá que vem buscando aumentar sua participação nesse mercado através de investimentos logísticos e mesmo com um volume menor em questão de volume em toneladas embarcadas se comparado com Aratu em questão de valores tem uma ligeira vantagem.

Pela alta representatividade do porto de Santos na exportação de algodão há um clara tendência que Santos irá dominar esse mercado ainda por um bom tempo, porém outras Aratu e Paranaguá estão buscando investir para promover e aumentar a sua participação nesse mercado tão relevante do agronegócio brasileiro. Em relação ao Covid-19 a disputa pelo mercado mundial ficará ainda mais acirrada para os produtores brasileiros de algodão, num cenário em que sobra oferta e faltam demanda apesar da China, maior importador já está se recuperando e a queda no volume também terá impacto por causa da oferta e concorrência já que da safra americana se inicia em breve, por outro com a moeda desvalorização do câmbio e da moeda brasileira é outro fator influenciador.

\section{CONSIDERAÇÕES FINAIS}

Conclui-se que, a capacidade, a localização e acessibilidade do porto de Santos ainda são fatores que garantem ao terminal portuário de Santos a hegemonia como o porto responsável pelo maior volume de exportação de algodão. 0 porto possui um importante papel na cadeia produtiva do algodão e os problemas de escoamento mesmo com os gargalos e desafios enfrentados pelo terminal há décadas. Infelizmente, estas falhas de infraestrutura fazem com que o produto nacional eleve seu custo e perca competitividade junto ao mercado internacional.

Respeitando os limites de capacidade de portos como o de Aratu e o porto de Paranaguá, a descentralização da demanda direcionada ao porto de Santos é, sem dúvidas, a melhor alternativa para o desafogamento que ocorre atualmente nos meses de picos da exportação do algodão. Novas alternativas para cadeia logística e processos burocráticos que envolvem a exportação do produto estão sendo constantemente estudadas e implantadas, para tornar a exportação nestes terminais portuários um processo o mais otimizado possível e aumentar a competitividade com o Porto de Santos.

Com a chegada do Covid-19 no cenário global, o comércio exterior foi impactado negativamente, o porto de Santos bem como o algodão ainda não sofreu tal impacto. Entretanto em reflexo ao mercado e concorrência internacional e possível retração econômica devido a pandemia a comercialização de algodão está passível de queda e poderá sofrer com alguma redução na movimentação. 


\section{REFERÊNCIAS}

[1]. ABRAPA. Associação Brasileira dos Produtores de Algodão. Algodão no Brasil Disponível em: < https://www.abrapa.com.br/Paginas/dados/algodao-nomundo.aspx >. Acesso em: 05 Mar.2020.

[2]. ABRAPA. Cadeia Produtiva do Algodão Brasileiro: Desafios e estratégias Biênio 2011/2012. Disponível em: <https://www.abrapa.com.br/EN-

US/BibliotecaInstitucional/Publica\%C3\%A7\%C3\%B5es/Livros/Livro\%20A\%20Cadeia \%20do\%20Algodao\%20-\%20Abrapa.pdf> Acesso em: 05 Mar.2020.

[3]. AGRONOVAS. Algodão: carregamento em conteineres. Disponível em: <http://www.agronovas.com.br/algodao-carregamento-em-conteineres/>. Acesso em:5 Mar.2020.

[4]. ALVES, Lucilio Aparecido; LIMA Fábio Francisco ET ALL Reações do mercado de algodão em um contexto de covid-19. Disponível em:

<https://www.researchgate.net/publication/340933178_Reacoes_do_mercado_de_algo dao_em_um_contexto_de_covid-19>. Acesso em: 05 Mar.2020.

[5]. ANEA. Estatísticas de exportação e importação. Disponível em: $<$ https://www.aneacotton.com.br/pt-br/servicos/estatisticas-exportacao-eimportacao/>. Acesso em: 05 Mar.2020.

[6]. BOLSA BRASILEIRA DE MERCADORIAS (BBM). Brasil pode liderar exportação de algodão nos próximos anos. Disponível em: <https://www.bbmnet.com.br/blog/brasilpode-liderar-exportacao-de-algodao-nos-proximos-anos>. Acesso em: 05 Mar.2020.

[7]. CANAL RURAL. Algodão bate recorde de área e volume. Disponível em: <https://www.canalrural.com.br/radar/algodao-mt-bate-recorde-de-area-e-volumeem-2019-afirma-imea/>. Acesso em: 05 Mar.2020.

[8]. COMEX DO BRASIL Em tempos de Covid-19, a boa notícia vem do campo: exportações de algodão crescem 82,8\% no trimestre Disponível em:

<https://www.comexdobrasil.com/em-tempos-de-covid-19-a-boa-noticia-vem-docampo-exportacoes-de-algodao-crescem-828-no-trimestre/>. Acesso em: 05 Mar.2020.

[9]. DATA MAR NEWS. TCP se especializa em exportações de algodão. Disponível em: <https://www.datamarnews.com/pt/noticias/tcp-se-especializa-em-exportacoes-dealgodao/>. Acesso em: 05 Mar.2020.

[10]. FIESP. Medidas de Comércio Exterior Relacionadas ao Combate à COVID-19. Atualizado em 27 MAR 2020 Disponível em:

$<$ https://coronavirus.fiesp.com.br/blog/medidas-de-comercio-exterior-relacionadasao-combate-a-covid-19>. Acesso em: 05 Mar.2020.

[11]. GARCIA-LORCA, D. R.; CARNERO ORTEGA, J. M. El algodón. Madrid: MundiPrensa, 1991. p. 242.

[12]. GIL, A. C. Métodos e técnicas de pesquisa social. 5.ed. São Paulo: Atlas, 1999.

[13]. GLOBO RURAL. Oeste Baiano consolida nova rota de exportação do algodão.

Publicado em 23 FEV 2018 Disponível em:

<https://revistagloborural.globo.com/Noticias/Agricultura/Algodao/noticia/2018/02/ oeste-baiano-consolida-nova-rota-de-exportacao-do-algodao-salvador.html $>$. Acesso em: 05 Mar.2020. 
[14]. IMEA. Relatórios Mercado. Disponível em: <http://www.imea.com.br/imeasite/relatorios-mercado>. Acesso em: 05 Mar.2020.

[15]. IICA/MAPA/SPA, 2007. Cadeia produtiva do algodão. Coord.. A Márcio Buainain; M Otávio Batalha. Brasília, BR. (Série Agronegócio v. 4). Disponível em: <http://repiica.iica.int/docs/B0591p/B0591p.pdf>. Acesso em: 05 Mar.2020.

[16]. JACTO. Acompanhe as principais estatísticas da agricultura mundial. Disponível em: <https://blog.jacto.com.br/agricultura-mundial/>. Acesso em: 05 Mar.2020.

[17]. MAPA. Projeções do Agronegócio. Brasil 2018/19 a 2028/29. Disponível em: <http://www.agricultura.gov.br/assuntos/politica-agricola/todas-publicacoes-depolitica-agricola/projecoes-do-agronegocio/projecoes-do-agronegocio-2018-20192028-2029/view>. Acesso em: 05 Mar.2020.

[18]. NOTICIAS AGRÍCOLAS. Algodão: Cenário pós-Covid sinaliza demanda retraída e exportações menores. Disponível em: <https://www.noticiasagricolas.com.br/noticias/algodao/257965-algodao-cenario-poscovid-sinaliza-demanda-retraida-e-exportacoes-menores.html>. Acesso em: 05 mar.2020.

[19]. PORTOS E NAVIOS. TCP Otimiza exportação de algodão em conteineres. Disponível em: <https://www.portosenavios.com.br/noticias/portos-e-logistica/tcpotimiza-exportacao-de-algodao-por-conteineres>. Acesso em: 05 Mar.2020.

[20]. SEVERINO, LIV SOARES , CHITARRA, LUIZ GONZAGA ET ALL. SÉRIE DESAFIOS DO AGRONEGÓCIO BRASILEIRO (NT3) Produto: ALGODÃO - Parte 01: Caracterização e Desafios Tecnológicos Disponível em: <https://www.alice.cnptia.embrapa.br/alice/bitstream/doc/1109655/1/SerieDesafios AgronegocioBrasileiroNT3Algodao.pdf>. Acesso em: 05 Mar.2020.

[21]. USDA. Cotton and Products Update 8/28/2019 Disponível em: <http://www.usdabrazil.org.br/pt-br/reports/cotton-and-products-update-2.pdf>. Acesso em: 06 de Mar. 2020 


\section{Capítulo 5}

\section{Segurança do trabalho na movimentação de carga a granel no Porto de Santos}

\section{Elizandra Paula do Valle Paula}

\section{Gabriel da Silva Sousa}

Resumo: Sabemos que a movimentação de carga a granel no Brasil tem grande importância e grandes resultados, por exemplo a soja, que é o carro chefe do país e o milho que vem ao longo dos anos batendo recordes de colheitas. Mas devemos olhar mais afundo para essa atividade, uma atividade que parece ser simples, mas que esconde centenas de riscos e perigos ao longo de todo o processo, desde a colheita até a etapa final de embarque no navio. Ao longo dos anos os métodos de segurança foram evoluindo, deixando mais seguro a vida do trabalhador portuário mas devemos alavancar nossa tecnologia neste quesito, pois acidentes e fatalidades continuam ocorrendo e devemos ter a consciência de que independentemente de recordes de colheitas e embarques uma morte é um resultados muito ruim para nossa estatística brasileira.

Palavras-chave: Morte. perigos. acidentes. carga a granel 


\section{INTRODUÇÃO}

Acidentes de trabalhos representam uma carga social e econômica expressiva. A mortalidade por acidentes de trabalho tem estimativa de 10,8/100.000 trabalhadores no mundo, no Brasil o numero é parecido, a estimativa é de 10,0/100.000 trabalhadores segurados (BATISTA, 2016).

A atividade portuária desde os tempos mais antigos tem ocupado um lugar de destaque na economia mundial. Tal atividade gerou uma necessidade de mão de obra que atuasse na realização da operação. Porém, as vidas das pessoas que trabalham nas atividades portuárias mostram que um porto é um ambiente desgastante e que apresenta condições adversas para os colaboradores (ANDRADE, 2012).

Com a revolução industrial, o uso de máquinas e outros equipamentos foram estabelecidos como fortes aliados no avanço da economia mundial. No Brasil, a primeira lei que trata sobre acidentes de trabalho foi a Lei $\mathrm{n}^{-} 3.724$, de 15/01/1919, e estava relacionada à prevenção no setor ferroviário. O ano de 1934 foi marcado pela regulamentação do que se refere a lei de prevenção de acidentes, mas apenas em 1943 foi aprovada a Consolidação das Leis Trabalhistas (CLT), por meio do Decreto Lei no 5.452, de 1o de maio de 1943. Apenas em 1978, o Ministério do Trabalho aprovou as Normas Regulamentadoras (NRs) que tratam sobre segurança, higiene e medicina do trabalho. (ANDRADE, 2012).

A preocupação com a atividade portuária se mostra presente nas resoluções da $3^{\text {a }}$ Conferência Nacional de Saúde do Trabalhador em sua versão final, de 24 de março de 2006. A Resolução Normativa no 253, de 5 de maio de 2011, foi o marco de investimento na área que afirma a priorização em estudos e pesquisas relacionadas aos impactos sociais sobre a segurança e saúde dos trabalhadores portuários, visando ao aperfeiçoamento da legislação específica (DUTRA, 2013).

Todas as empresas investem recursos e tempo para que a mão de obra esteja qualificada e para que os processos sejam implementados da melhor forma possível, a fim de minimizar os riscos das operações. Os procedimentos são sempre elaborados para buscarem enfatizar os riscos e medidas de controle e deixar claro aos empregados a melhor forma de executar as atividades, que descreve um processo lógico, para que estes realizem as atividades de forma sistemática e com o menor risco possível (SOARES, 2018).

Além dos treinamentos e procedimentos, as empresas investem também em EPI's cada vez mais eficientes e confortáveis. Geralmente, essas ações são mais utilizadas e, de certa forma, geram um resultado positivo quando se fala em redução dos acidentes do trabalho. Entretanto, com a constante evolução da tecnologia, é preciso também modernizar a forma como se pensa a segurança do trabalho. É importante lembrar que utilizando tecnologias, geralmente se trabalha nas partes mais elevadas da pirâmide de barreiras de proteção, sendo eliminação, substituição ou controles de engenharia, entretanto deve se avaliar quais as tecnologias devem ser empregadas e quais os efeitos que essas novas tecnologias trazem para que não sejam mais um novo risco ao processo (SOARES, 2018).

0 objetivo deste trabalho é abordar um tema muito importante quando se trata de operação, a segurança do trabalhador portuário é primordial para se atingir bons resultados e por isso não deve ser deixado de lado quando observamos as movimentações de cargas a granel e entre outros produtos exportados pelo Brasil. 


\section{REFERENCIAL TEÓRICO}

A Segurança do Trabalho surgiu no mundo, segundo estudos, na Grécia Antiga, sendo citadãos, por exemplos, os registros de Aristóteles sobre as enfermidades dos trabalhadores nas minas. No entanto, apenas em 1713, uma obra de Bernardino Ramazzini, intitulada "As doenças dos trabalhadores" foi obra que de fato marcou o surgimento da Segurança do Trabalho no contexto mundial. 0 autor descreve várias doenças relacionadas a algumas profissões da época e devido a repercussão do seu estudo, Ramazzini é inclusive considerado o pai da Medicina do Trabalho (BLOG SEGURANÇA DO TRABALHO, 2018).

No final do século XVIII, na Inglaterra, a Primeira Revolução Industrial provocou a permuta da manufatura para a maquinofatura, assim o mercador transformou-se em capitalista quando soube converter a mão de obra em mercadoria e essa transição trouxe mudanças significativas para a vida do trabalhador, que migrou do seu espaço rural para as cidades em busca de vender sua força de trabalho para as indústrias. De fato, com a mão de obra disponível a granel e o recrudescimento da migração, o meio ambiente de trabalho dos operários era o pior possível, com jornadas excessivas e salários baixos. Diante disso, os trabalhadores aceitavam condições estipuladas unilateralmente pelo empregador e naquela época, era inelutável e ainda comum a ocorrência de acidentes de trabalho pela jornada de trabalho extensa e sem intervalos. Vários trabalhadores apresentavam sinais de lesões por esforços repetitivos e Distúrbios Osteomusculares Relacionados ao trabalho (ÂMBITO JURÍDICO, 2016).

No Brasil Império e na Primeira República podem ser apontados momentos em que a indústria brasileira alcançou um pequeno avanço, como a Era Mauá e o crescimento da produção de bens de consumo não duráveis. 0 presidente, Getúlio Vargas chegou ao poder traçando um projeto industrialista que foi marcado pela intervenção estatal na economia, que resultou na construção da Vale do Rio Doce, da Eletrobrás e da Petrobrás. Getúlio Vargas buscou, por meios de medidas protecionistas, instituir uma industrialização por substituição de importação, visando fortalecer a economia e o mercado interno. Com essa mudança de produção, que passa a ser em massa, surgem diversos movimentos sociais, representado pelos tratados e convenções que buscavam consolidar os direitos dos trabalhadores. Com isso, o presidente criou a Consolidação das Leis Trabalhistas, que previa diversos direitos à classe operária, dentre eles a segurança do trabalho (BLOG SEGURANÇA DO TRABALHO, 2018).

A metodologia utilizada neste é a pesquisa bibliográfica, por meio consultas em artigos, dissertações e livros referentes ao tema abordado.

\section{DESENVOLVIMENTO DA TEMÁTICA}

Em 25 de Agosto de 2020, um operador da máquina denominada Pá Carregadeira morreu soterrado no Terminal XXXIX (-T-39), localizado na margem direita do Porto de Santos. Em maio do mesmo ano, a Rumo Logística Operadora Multimodal S.A foi condenada a pagar uma multa de $\mathrm{R} \$ 2$ milhões pelo acidente seguido por morte quando um trabalhador exercia atividade não compatível com a função, em local de baixa luminosidade e sem as proteções e cuidados necessários. O laudo apontou que as rés apresentaram negligências e a empresa não disponibilizou treinamento referente às normas de segurança que trata sobre movimentação de trens $(G 1,2020)$.

Voltando alguns anos, na Santos Brasil, margem esquerda do Porto de Santos, em 23 de Junho de 2007, um estivador foi o sexto a ir a óbito no ano, vítima da insegurança das 
operações no Porto. Ele morreu a bordo de um navio com bandeira panamenha, $\mathrm{Yu} \mathrm{Gu}$ He, esmagado por um contêiner, 3 semanas depois de um companheiro ter perdido a vida no porão de um navio de enxofre, no Terminal Marítimo de Guarujá (TERMAG). No mesmo dia, um trabalhador se acidentou no mesmo navio e um operário da capatazia perdeu o dedo durante operação no Armazém 12. Dois dias depois, um trabalhador caiu e bateu a cabeça, na Santos Brasil e, à noite, um estivador se machucou dentro da Libra Terminais (PORTOGENTE, 2007).

Partindo para a segurança das instalações, em 18 de Outubro de 2013, três armazéns da Copersucar (-armazéns 6, 20 e 21-) pegaram fogo. 0 incêndio iniciou por volta da 6 horas da manhã. (EXAME, 2013). Em 20 de Outubro de 2015, outro incêndio de grandes proporções atingiu Terminal Exportador de Açúcar de Guarujá (TEAG), o alarme foi soado por volta das 5 horas da manhã, com uma preocupação maior porque ao lado fica o TERMAG, que armazena cargas explosivas, como o enxofre $(G 1,2014)$. Mais um incêndio ocorreu em 27 de Novembro de 2019, no Terminal Sucocítrico Cutrale, as chamas atingiram a região do píer, o terminal também opera com soja, suco de laranja e farelo de casca cítrica (SISTEMA COSTA NORTE DE COMUNICAÇÃO, 2020).

Voltando à cadeia logística da carga a granel, por exemplo à soja e ao milho, nas fazendas de plantio existe uma atividade muito perigosa, que é a de armazenamento em silos. Segundo à BBC News Brasil, o professor Idalberto Almeida de Medicina no Trabalho da Universidade Estadual Paulista (Unesp), em Botucatu, diz que o levantamento indica que o trabalho em silos está entre as atividades com mais acidentes fatais no país, depois das profissões sujeitas as mortes no trânsito. Não há dados oficiais precisos sobre as mortes em armazéns agrícolas no Brasil. Quando trabalhadores sofrem acidentes, é responsabilidade do empregador informar a ocorrência ao Ministério da Previdência Social, e no formulário de notificação não há um código para armazéns agrícolas, fica apenas englobado na categoria "depósitos fixos". Segundo o Ministério, o setor de armazenagem que inclui o trabalho em silos de grãos, mas também em vários outros tipos de armazéns, teve 11,3 mortes para cada 100 mil trabalhadores, em 2016, último ano com dados disponíveis. Este valor deixa o setor entre os $25 \%$ dos campos econômicos mais mortíferos para trabalhadores no país. Entre 2012 e 2017, o Ministério Público da União registrou 14 mortes por trabalhadores por asfixia, estrangulamento ou afogamento causados por cereais e derivados (BBC NEWS BRASIL, 2018).

Em relação ao volume embarcado da commodities soja e milho, dados obtidos. Dados obtidos do Terminal Exportador do Guarujá (TEG) e do Terminal Exportador de Açúcar do Guarujá (TEAG), dos anos de 2018, 2019 e 2020, mostram números bem positivos de volume embarcado de soja e milho no acumulado que está representado na Tabela 1. Nesta tabela, os volumes estão somados entre os dois terminais, pois ambos estão situados no mesmo espaço e a mão de obra é compartilhada entre eles.

Tabela 1 - Total embarcado de soja e milho nos anos de 2018, 2019 e 2020, dos terminais TEG e TEAG

\begin{tabular}{|l|c|c|c|}
\hline \multicolumn{1}{|c|}{ SOJA- TEAG } & 782.051 & 2019 & 2020 \\
\hline SOJA- TEG & 2.776 .048 & 2.187 .127 & 2.078 .336 \\
\hline MILHO- TEAG & 0,0 & 68.200 & 137.357 \\
\hline MILHO- TEG & 2.219 .786 & 2.660 .900 & 2.634 .563 \\
\hline TOTAL & $\mathbf{5 . 7 7 7 . 8 8 5}$ & $\mathbf{5 . 9 8 7 . 7 7 2}$ & $\mathbf{6 . 5 4 1 . 3 3 3}$ \\
\hline
\end{tabular}

Fonte: TEG (2021) 
Utilizando dados, uma outra informação estatística foi obtida para medir alguns indicadores específicos. Por exemplo, comparando esses volumes embarcados à quantidade de acidentes com potencial SIF (Serious Injuries and Fatality), que significa acidente ou incidente com potencial de perda de membro, perda de movimento ou fatalidade, dentro dos anos apresentados, pode-se perceber uma relação linear entre eles. 0 Gráfico 1 mostra as quantidades embarcadas e as ocorrências de acidentes.

Gráfico 1 - Comparativo do total embarcado dos anos 2018, 2019 e 2020 com a quantidade total de acidentes e incidentes com potencial SIF

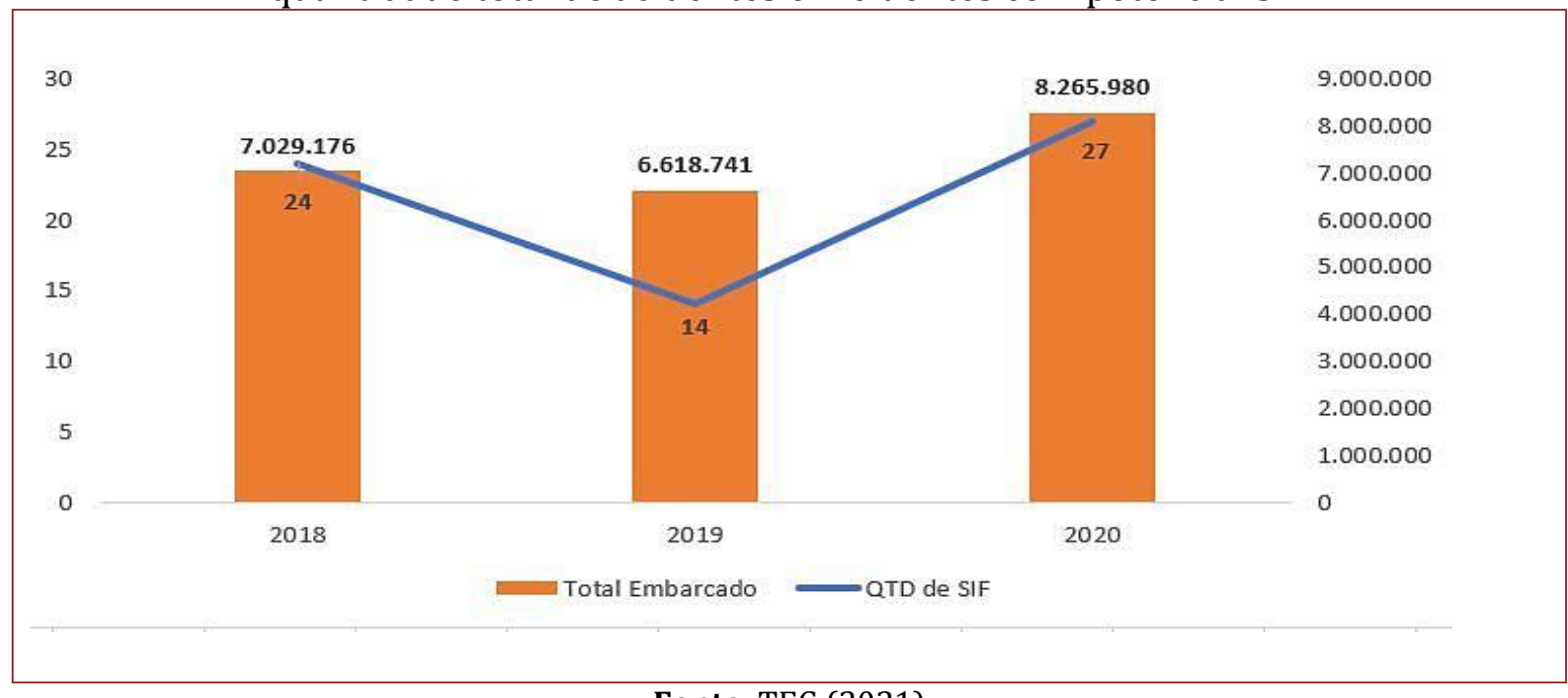

Fonte: TEG (2021)

No Gráfico 2, podemos analisar os tipos de acidentes de maior ocorrência, ao longo dos três anos, na planta. Os tipos estão divididos em doze temas, os quais oferecem riscos à vida dos trabalhadores e à planta do terminal.

Gráfico 2 - Comparativo entre os anos 2018, 2019 e 2020 de precursores de acidentes potencial SIF

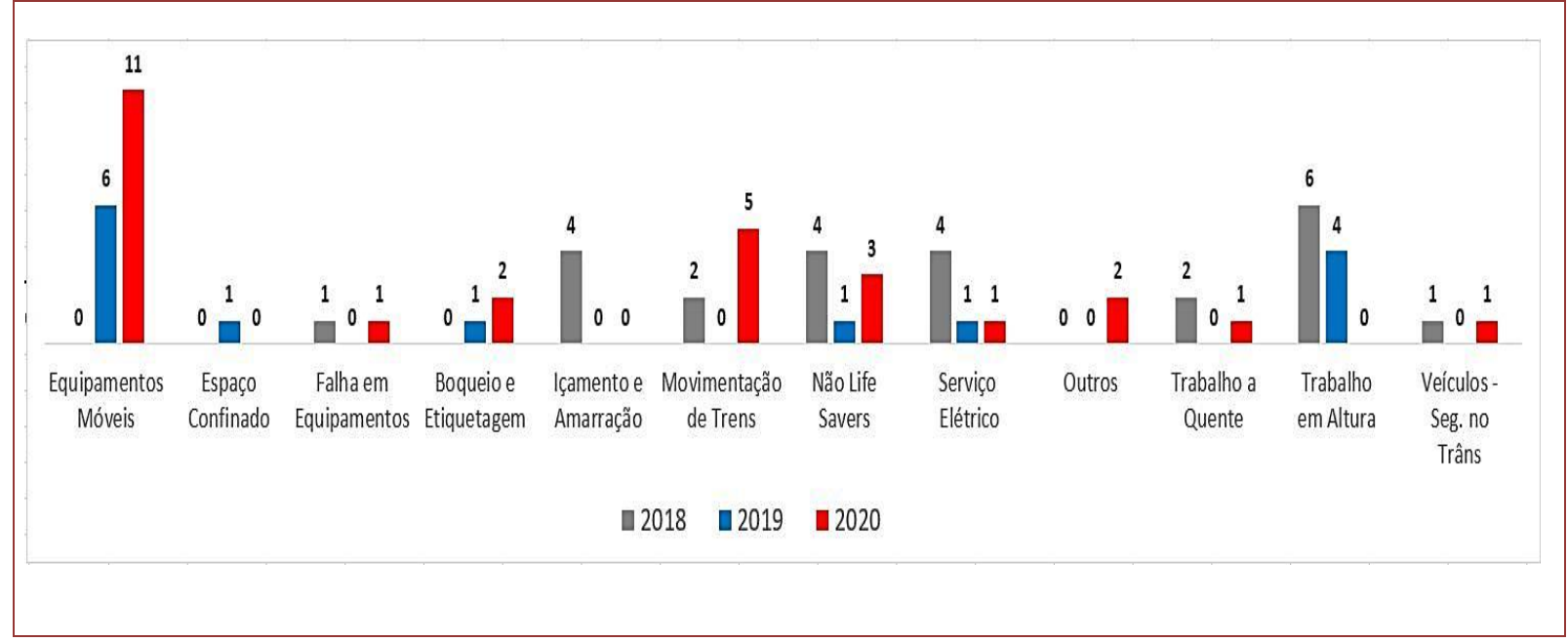

Fonte: TEG (2021) 


\section{RESULTADOS E DISCUSSÃO}

Ao decorrer das informações apresentadas, é perceptível a necessidade de um olhar crítico, uma preocupação, com a segurança do trabalho na movimentação de carga a granel, desde a sua origem até o seu embarque. Toda e qualquer atividade contempla riscos e perigos para o trabalhador, por este motivo, as ações devem ser mapeadas para que se possa desenvolver barreiras de proteções e, mesmo que já existam, estas devem ser melhoradas para eliminar o risco. Não se pode aceitar os recordes registrados ao longo dos anos, quando vidas de trabalhadores são interrompidas.

No Gráfico 2 podemos se verificar que as atividades com equipamentos móveis foram as de maior ocorrência, isso porque o uso de maquinários ocorre desde o início da cadeia produtiva. Para a soja e o milho, por exemplo, são usadas máquinas para preparar o solo, máquinas para fazer o plantio da semente, máquinas para colheita. Na outra ponta da cadeia, no porto, também se usa maquinário móvel, como as pás carregadeiras, para fazer o rechego (movimentação interna) da carga em armazéns ou para fazer o escoamento da carga nas bicas, quando estão compactadas. As pás carregadeiras e tratores são utilizados para movimentar vagões carregados e vazios, no interior das empresas. 0 risco está na perda de controle durante a operação de puxada resultando em colisão, por falha humana ou mecânica, causada por comando imprudente, falta de visibilidade da cauda da composição e condições inadequadas de operação.

Com o objetivo de reduzir este tipo de acidente, os tratores e pás carregadeiras para puxar vagões podem ser substituídos por veículos com diferentes tecnologias. Uma das tecnologias testadas em terminais de granel é o Robô de Manobra. 0 equipamento eliminaria a presença de um colaborador na linha de frente da puxada de vagões, mantendo-o a uma distância segura, visualizando tudo à frente da linha férrea por onde a composição deve seguir e sua cauda de forma mais eficaz. Todo o controle é feito de forma remota, não havendo necessidade alguma da exposição ao risco de colisão e atropelamento.

O equipamento possui baixo custo operacional e de manutenção, a alimentação de energia ocorre à livre escolha, podendo ser por tambor de cabo, cabo de arrasto, barramentos de contato, bateria de alto desempenho ou acionamento diesel-elétrico. (VOLLERT, 2021) Existe também o mesmo equipamento bimodal, que serve tanto para o ferroviário quanto o rodoviário, o que isso significa, o mesmo robô auxiliaria também em uma puxada de caminhão caso ocorra algum problema no interior do terminal durante a descarga do produto no tombador, reduzindo o tempo de parada da operação.

Esta tecnologia é muito importante. Na pirâmide de hierarquia de camadas de defesa, a utilização de EPI's é a forma mais simples de redução de riscos e perigos e, a parte mais eficaz, é a eliminação da atividade. No caso do robô de manobra, este substitui o equipamento atual da atividade, eliminando os riscos para o colaborador na movimentação de vagões. A Figura 1 mostra o método tradicional utilizado atualmente, utilizando uma pá carregadeira para movimentar a composição. 
Figura 1 - Método tradicional de puxada de vagões

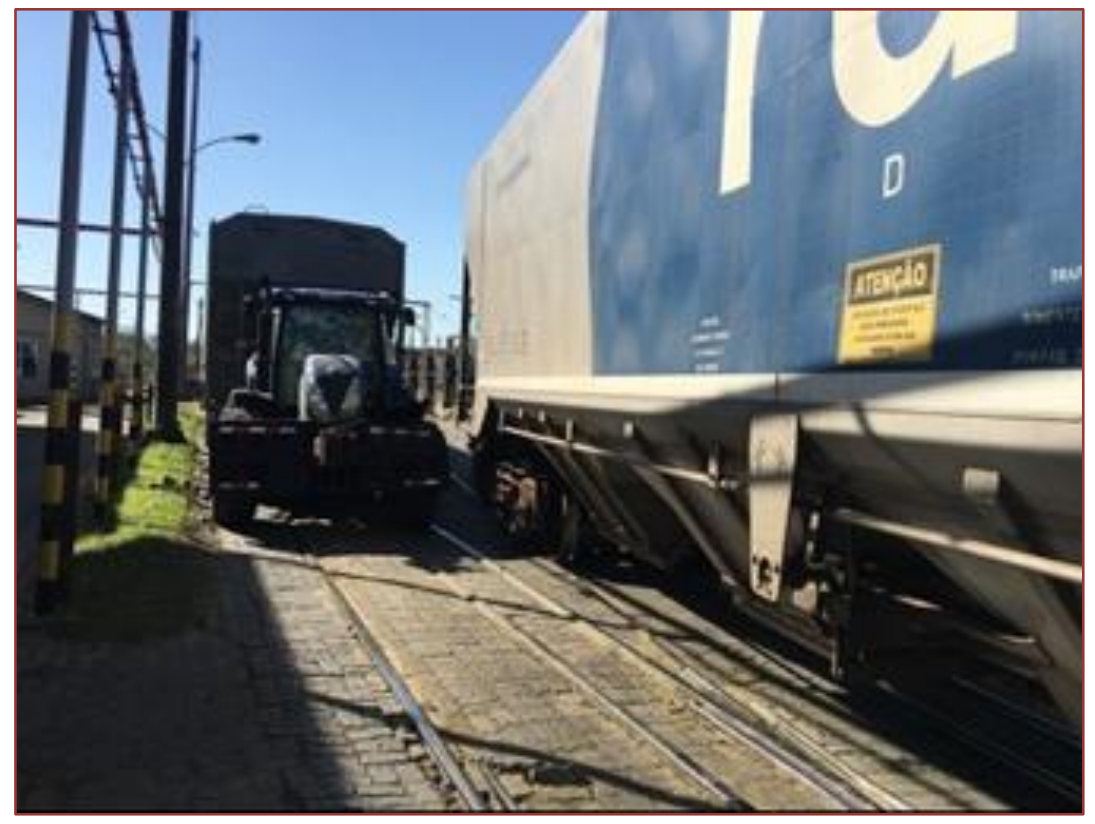

Fonte: TEG (2020)

A Figura 2 mostra o robô de manobra realizando a atividade de movimentação da composição.

Figura 2 - Método de puxada de vagões com o robô
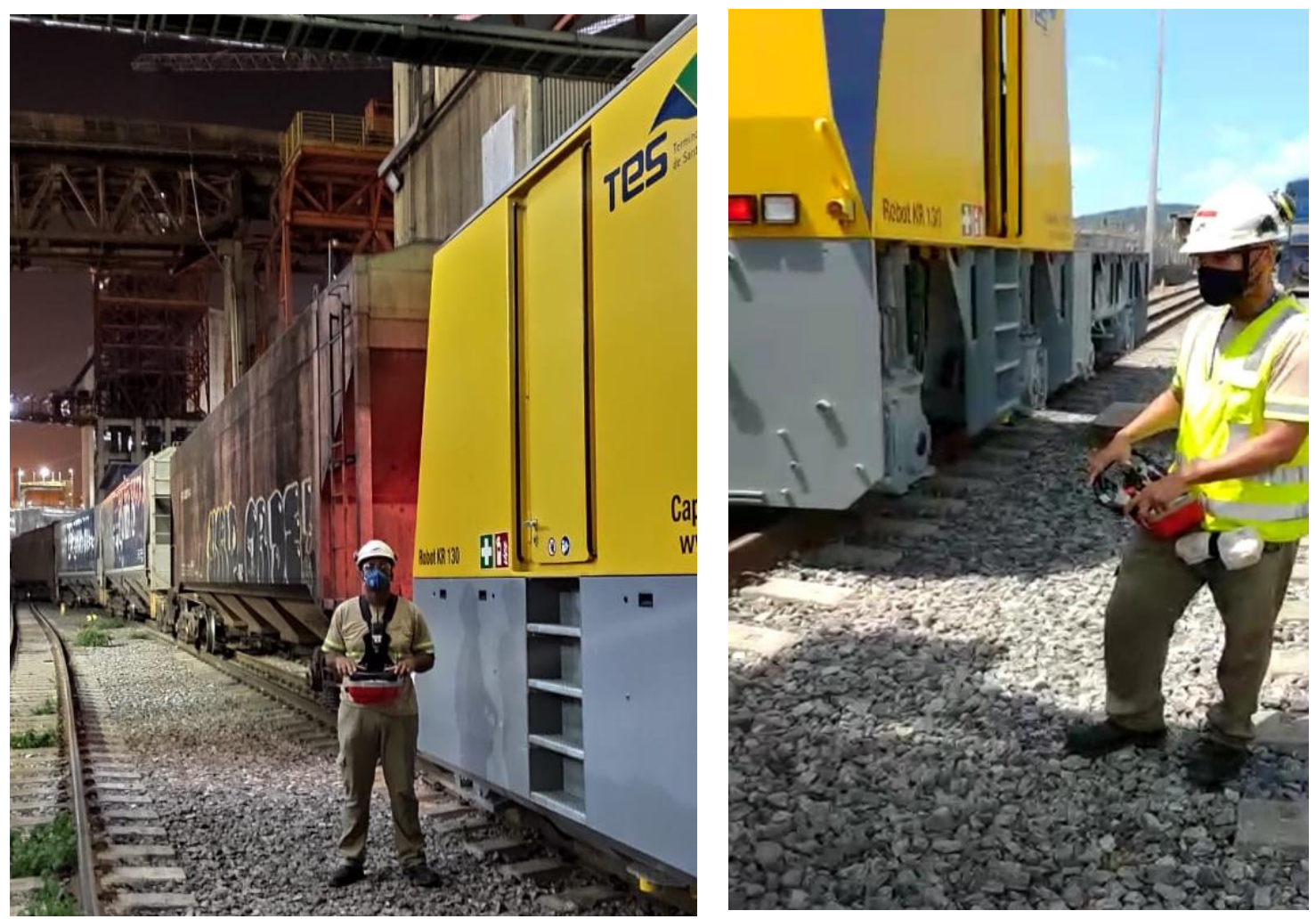

Fonte: TES (2021) 


\section{CONSIDERAÇÕES FINAIS}

Este artigo traz considerações sobre a necessidade das empresas aumentarem seus investimentos em tecnologia no setor da segurança do trabalho. 0 Brasil deve seguir 0 modelo de portos estrangeiros, que têm investimentos fortíssimos constantes em tecnologia, adquirindo equipamentos mais avançados e mais desenvolvidos no quesito segurança operacional.

No passado, a mão de obra era a essência das fabricas, pois não existia maquinário algum desenvolvido pensando na segurança dos colaboradores, Os acidentes de trabalho não tinham importância para os líderes da época, e no caso de afastamento de funcionário por acidente, este era substituído e a perda de vidas não tinha peso significativo para os empresários.

Ao longo dos anos, os conceitos foram mudando, as revoluções influenciaram para as mudanças, trazendo avanços no setor da saúde que possibilitaram uma melhoria na qualidade de vida da população. No Brasil, o avanço foi tardio em comparação com a Europa, mas chegou, em 1919, quando foi criada a lei de Acidentes de trabalho, que tornou compulsório o seguro contra o risco profissional. Em1923, houve a criação da caixa de aposentadorias e pensões para os empregados das empresas ferroviárias que foi o marco da Previdência Social, em 1930, a criação do Ministério do Trabalho, Indústrias e Comércio, em 1943, foi criada a consolidação das leis do trabalho, a CLT que trata de segurança e saúde do trabalho e, em 1978, foi a vez da criação das normas regulamentadoras.

O novo conceito de saúde foi consolidado, não relacionado apenas a inexistência das doenças e sim enfatizando a plena saúde física, mental e social. As normas legais buscam hoje em dia um ambiente de trabalho saudável, sem a única preocupação com existência de agentes de risco, mas sim com atenção na prevenção de qualquer fator negativo do ambiente de trabalho.

Os gráficos apresentados indicam que, o aumento da produtividade em um terminal portuário pode estar relacionado ao aumento dos acidentes com potencial SIF. Como o Brasil vem, ao longo dos anos, batendo recordes de exportação de material a granel, os números de acidentes nas empresam também tendem a aumentar. Já o gráfico das atividades com maior ocorrência de acidentes na planta da empresa, foi possível destacar que os equipamentos móveis têm grande influência neste resultado negativo de acidentes. Com isso é apresentada uma possível solução tecnológica visando à redução de risco de acidentes com os operadores, já que seu controle é feito de forma remota totalmente externa do equipamento.

A tecnologia esta presente para melhorar a performance dos terminais portuários não apenas de forma operacional, mas também na segurança de todos, em melhorias na forma ergonômica, na necessidade de primeiros socorros, no combate a incêndio, na segurança patrimonial entre outras áreas, mas para isso é essencial o investimento. 


\section{REFERÊNCIAS}

[1]. ÂMBITO JURÍDICO.Acidente de trabalho: histórico, conceito e normas gerais de tutela do empregado. 2016. Disponível em: https://ambitojuridico.com.br/edicoes/revista-153/acidentede-trabalho-historico-conceito-e-normas-gerais-de-tutela-do-empregado/. Acesso em: 26 mar. 2021.

[2]. BATISTA, Adriana Galdino. QUALIDADE DOS REGISTROS DE DADOS SOBRE ACIDENTES DE TRABALHO FATAIS NO BRASIL. 2016. 94 f. Tese (Doutorado) - Curso de Doutorado em Saúde Pública, Universidade Federal da Bahia, Salvador, 2016.

[3]. BBC NEWS (São Paulo). As silenciosas mortes de brasileiros soterrados em armazéns de grãos. 2018. Disponível em: https://www.bbc.com/portuguese/brasil-45213579. Acesso em: 24 mar. 2021.

[4]. BLOG SEGURANÇA DO TRABALHO. Como surgiu a Segurança do Trabalho. 2018. Disponível em: https://www.blogsegurancadotrabalho.com.br/como-surgiu-a-seguranca-dotrabalho/\#: :text=No\%20entanto\%2C\%20a\%20obra\%20que,profiss\%C3\%B5es\%20que\%20e xistiam\%20na\%20\%C3\%A9poca. Acesso em: 26 mar. 2021.

[5]. DUTRA, Maria Cristina. SAÚDE E SEGURANÇA DO TRABALHADOR PORTUÁRIO: A busca de diretrizes nacionais para os portos brasileiros. 2013. 92 f. TCC (Graduação) - Curso de Curso de Especialização em Engenharia e Gestão Portuária, Universidade Federal de Santa Catarina, Santa Catarina, 2013.

[6]. EXAME (Santos). Incêndio atinge três armazéns da Copersucar em Santos. 2013.

Disponível em: https://exame.com/negocios/incendio-atinge-tres-armazens-da-copersucar-emsantos/. Acesso em: 23 mar. 2021.

[7]. G1 (Santos). Incêndio de grandes proporções atinge terminal em Guarujá, SP. 2014. Disponível em: http://g1.globo.com/sp/santos-regiao/noticia/2014/10/incendio-de-grandesproporcoes-atinge-terminal-em-guaruja-sp.html. Acesso em: 21 mar. 2021.

[8]. G1 (Santos). Justiça condena operadora portuária após acidente fatal com trabalhador em SP. 2020. Disponível em: https://g1.globo.com/sp/santos-regiao/porto$\mathrm{mar} /$ noticia/2020/05/04/justica-condena-operadora-portuaria-apos-acidente-fatal-comtrabalhador-em-sp.ghtml. Acesso em: 21 mar. 2021.

[9]. G1 (Santos). Trabalhador morre ao ser soterrado por 'montanha' de soja no Porto de Santos. 2020. Disponível em: https://g1.globo.com/sp/santos-regiao/portomar/noticia/2020/08/25/operador-de-maquina-morre-apos-acidente-em-terminal-no-portode-santos.ghtml. Acesso em: 22 mar. 2021.

[10]. PORTOGENTE. Em 48 horas, cinco trabalhadores sofrem acidentes no Porto. 2007. Disponível em: https://www.portogente.com.br/noticias-do-dia/12473. Acesso em: 24 mar. 2021.

[11]. SISTEMA COSTA NORTE DE COMUNICAÇÃO (Santos). Terminal da Cutrale pega fogo em Guarujá. 2019. Disponível em: https://costanorte.com.br/seguranca/terminal-da-cutrale-pegafogo-em-guaruj\%C3\%A1-1.26091. Acesso em: 23 mar. 2021.

[12]. VOLLERT. Robô de Manobra. Disponível em: https://www.vollert.de/pt/areas-deprodutos/solucoes-para-sistemas-de-manobra/robo-de-manobra/. Acesso em: 25 mar. 2021.

[13]. SOARES, Nonato. Envolvendo a Tecnologia na Segurança do Trabalho. 2018. Disponível em: http://prevencaosaudavel.blogspot.com/2018/09/envolvendo-tecnologia-na-segurancado.html. Acesso em: 25 mar. 2021. 


\section{Capítulo 6}

\section{A matriz ferroviária e o impacto no transporte de cargas pelo Porto de Santos}

\section{Amanda Gabriela dos Santos Castilho}

\section{Gustavo Silva dos Santos}

Resumo: 0 modal ferroviário é um dos meios de transporte mais adequado para o transporte de cargas devido a sua alta capacidade de transporte, baixo custo de manutenção e benefícios ao meio ambiente. No Brasil devido a falta de incentivo, a participação das ferrovias no setor de transportes é relativamente baixa se avaliarmos nossa extensão territorial. No Porto de Santos, o maior da américa latina, o modal ferroviário corresponde a $27 \%$ do total das cargas que são movimentadas, tendo o modal rodoviário uma predominância no setor, o que torna o processo logístico mais oneroso. Devido a investimentos e incentivos da iniciativa pública e privada o Porto de Santos está se movimentando para uma maior integração multimodal, seguindo o modelo utilizado em diversos países. Este artigo de caráter exploratório e abordagem qualitativa com embasamento bibliográfico, tem por finalidade mostrar a importância de uma matriz ferroviária eficiente, levantando projetos que visam a melhoria desse modal, proporcionando de maneira específica os ganhos logísticos, usando de comparações o modal rodoviário, principal modal utilizado para o transporte de cargas no porto de Santos.

Palavras-chave: Ferrovia. Transporte. Expansão. 


\section{INTRODUÇÃO}

Atualmente, há uma dependência do modal rodoviário pelo Porto de Santos, o modal ferroviário representa apenas $27 \%$ do transporte total de cargas movimentadas pelo porto (Dados Santos Port Authority - SPA). De acordo com a SPA, até o mês de julho deste ano já foram movimentados mais de 85 milhões de toneladas em cargas, mesmo em meio a pandemia causada pelo COVID-19. Segundo a própria SPA, para 2040 a expectativa em movimentação de cargas ultrapassará a marca dos 214 milhões em toneladas, o que nos mostra a necessidade de se apostar na intermodalidade do transporte.

Uma das restrições que impedem o avanço do modal ferroviário é a questão das suas diferentes concessões, fato que gera a necessidade de requerer o "direito de passagem" nos trechos de concessionárias distintas. Outro limite operacional imposto, é o fato de que as malhas permitem apenas um trem por vez, e há as restrições de horário, pois em muitos trechos as linhas são divididas com trens da CPTM. Vários projetos visam beneficiar esse modal, o mais famoso seria o "Contorno Ferroviário da Região Metropolitana de São Paulo", conhecido como Ferroanel, projeto este que interliga as principais ferrovias da Região Metropolitana de São Paulo com o objetivo ampliar a capacidade do transporte ferroviário na região e separar a operação do transporte de cargas do transporte urbano de passageiros nas linhas que são utilizadas em conjunto pela Companhia Paulista de Trens Metropolitanos (CPTM) e pela M.R.S Logística S.A, proporcionando uma melhoria no sistema de transporte ferroviário da região.

De acordo com o PNL (Plano Nacional de Logística), o transporte ferroviário é um dos tipos de transportes mais seguros, tendo um baixo impacto ambiental e possuindo um custo operacional e de manutenção baixos, em relação à quantidade de carga transportada. É um meio de transporte vantajoso pois possui maior capacidade de carga, além de percorrer grandes distâncias com baixo consumo de energia, sem falar que o frete de cargas neste meio de transporte é em média 15\% menor do que o valor pago no transporte feito pelas rodovias. É o segundo meio de transporte mais utilizado para movimentação de cargas no país, sendo necessário um melhor desenvolvimento para que se tenha um melhor aproveitamento logístico deste tipo de modal.

Este artigo tem como objetivo geral mostrar a importância de uma matriz ferroviária eficiente e trazendo ganhos para a economia brasileira, e levantar projetos que visam a melhoria desse modal. Com o objetivo específico de apontar os ganhos logísticos usando de comparações entre os principais modais utilizados para o transporte de carga no porto de Santos.

Segundo Andrade (2001, p.121) a pesquisa científica é um conjunto de procedimentos sistemáticos, apoiado no raciocínio lógico e que usa métodos científicos para encontrar soluções para problemas pesquisados. A pesquisa científica é muito importante pois é responsável pela aquisição a a produção de conhecimento. É por meio dela que os pesquisadores entendem o mundo e solucionam problemas que transformam o mundo em que vivemos. Esta pesquisa tem caráter exploratório e abordagem qualitativa com base documental e bibliográfica, Prodanov e Freitas (2013, p. 126).

\section{FUNDAMENTAÇÃO TEÓRICA OU REVISÃO DA LITERATURA}

Devido a competitividade no mercado atual, as empresas tem recorrido ao uso de ferramentas que otimizem seus métodos de gestão. Dentre estas ferramentas, o gerenciamento da cadeia de suprimentos, ou Supply Chain Management (SCM), é um 
mecanismo que vem se desenvolvendo e popularizando com o passar dos anos. De acordo com Ronald H. Ballou (2006, p. 29), "A Logística/Cadeia de Suprimentos é um conjunto de atividades funcionais (transportes, controle de estoques, informações, etc.) que se repetem inúmeras vezes ao longo do canal pelo qual matérias-primas vão sendo convertidas em produtos acabados, aos quais se agrega valor ao consumidor."

A gestão da cadeia de suprimentos envolve questões operacionais externas como compras, depósitos, inventários e etc, sendo uma rede que envolve fabricantes, fornecedores, clientes e demais parceiros de uma empresa. A gestão da cadeia de suprimentos é utilizada como ferramenta estratégica que tem como finalidade minimizar os custos de produção e obter vantagens competitivas eliminando atividades desnecessárias e promovendo um grau elevado de satisfação ao cliente.

De acordo com a ANTT (Agência Nacional dos Transportes Terrestres), dos mais de 29 mil quilômetros de ferrovias existentes no Brasil, mais de um terço da malha ferroviária existente está em estado de abandono, e cerca de 10 mil quilômetros foram construídos no século passado. Apesar da dependência do modal rodoviário o país sofre com o alto índice de estradas deficitárias, apenas $12 \%$ da malha rodoviária é pavimentada (dados CNT - Confederação Nacional do Transporte).

Economicamente falando, é muito mais vantajoso transferir as cargas de longa distância para ramais de transporte alternativos como as ferrovias e deixar os caminhões com as viagens de curta distância e para fazer a interligação de carga e descarga nos locais aonde os trilhos não chegam. Deste modo, investimentos voltados para terminais de transporte intermodal são uma outra necessidade a ser avaliada para que a matriz de transportes brasileira obtenha o tão esperado equilíbrio, tornando assim as ferrovias mais competitivas e com uma visão voltada para a integração dos modais não de forma a competirem um com o outro, mas trabalhando em conjunto como parceiros comerciais.

De acordo com Ronald Ballou no livro Gerenciamento da Cadeia de Suprimentos, o transporte demonstra ser o elemento mais importante em termos de custos logístico, chegando a absorver de um a dois terços dos custos logísticos totais. (2006 p.150). Por isso dá importância da sua escolha, visando melhor custo benefício, contribuindo com uma melhor oferta de produtos, tanto em quantidade quanto em preço.

No livro qualidade e produtividade dos transportes, é destacado a disponibilidade, confiabilidade e segurança como parâmetros de maior interesse para os clientes que buscam o modal ferroviário. (VALENTE: PASSAGLIA: CRUZ: MELLO: CARVALHO: MAYERLE: SANTO, 2008).

De acordo com o livro Operação Ferroviária, o autor Rodrigo Rosa apresenta as principais características do modal ferroviário, sendo elas: o transporte de grandes volumes, eficiência energética, menor índice de acidentes. 0 tipo de transporte deste modal pode ser dividido em contêineres e outros dois grupos, granel (grãos, minério, cimento, adubos, carvão e etc...), onde sua medição é feita por peso, e a carga geral, que é medida por unidade. (ROSA, 2016). 
Para a realidade brasileira, sua implementação depende do ganho econômico que se terá, pois de acordo com Cassio Paiva, autor do livro Super e Infraestruturas de Ferrovias, o seu custo de construção é muito elevado, mas seu retorno se daria por baixíssimo valor de frete, ressaltando ainda a demanda reprimida que o pais tem em desenvolver novas rotas, (PAIVA, 2016).

\section{DESENVOLVIMENTO DA TEMÁTICA}

A frase "Governar é abrir estradas" dita então pelo nosso $13^{\circ}$ Presidente a V. EX Washington Luís dá à mostra o quão esquecido foi o programa de construção de ferrovias a partir dos anos 30, dando preferência para a construção de rodovias, vistas como as vias do futuro, e atrativas pelo seu custo baixo de implementação.de acordo com a associação nacional dos transportadores ferroviários - ANTF o transporte por rodovias representa $65 \%$ da composição nacional.

Imagem 1 Comparação entre modais por países

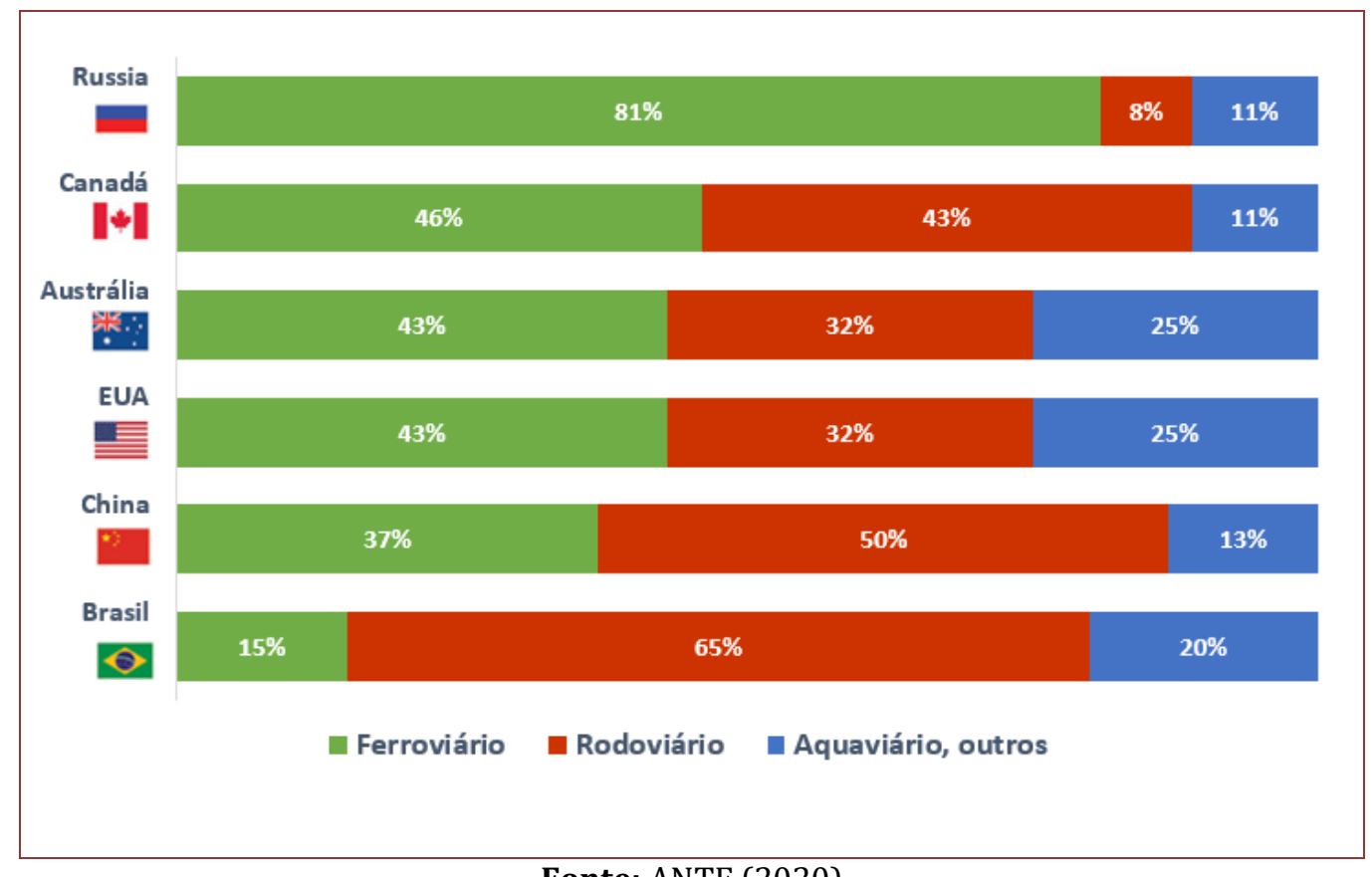

Fonte: ANTF (2020)

O transporte ferroviário de cargas é um dos meios mecanizados de transporte precursores na movimentação de carga no mundo e desempenha um papel fundamental na logística mundial. As principais economias do mundo tem a ferrovia como base no transporte de cargas, uma vez que a infraestrutura ferroviária é essencial para qualquer país (Dados ABIFER). Por este motivo, implementar estratégias para otimização desse processo são imprescindíveis para redução dos custos operacionais e o transporte intermodal é uma excelente alternativa para resolução dessa questão. De acordo com a Associação Nacional dos Transportes Rodoviários - ANTF, o Brasil dispõem atualmente de $29.320 \mathrm{~km}$ de ferrovias, tendo sua concentração na região sudeste do pais. De acordo com a imagem 2 é possível analisar sua distribuição geograficamente. 
Imagem 2 Projeção de demanda e capacidade

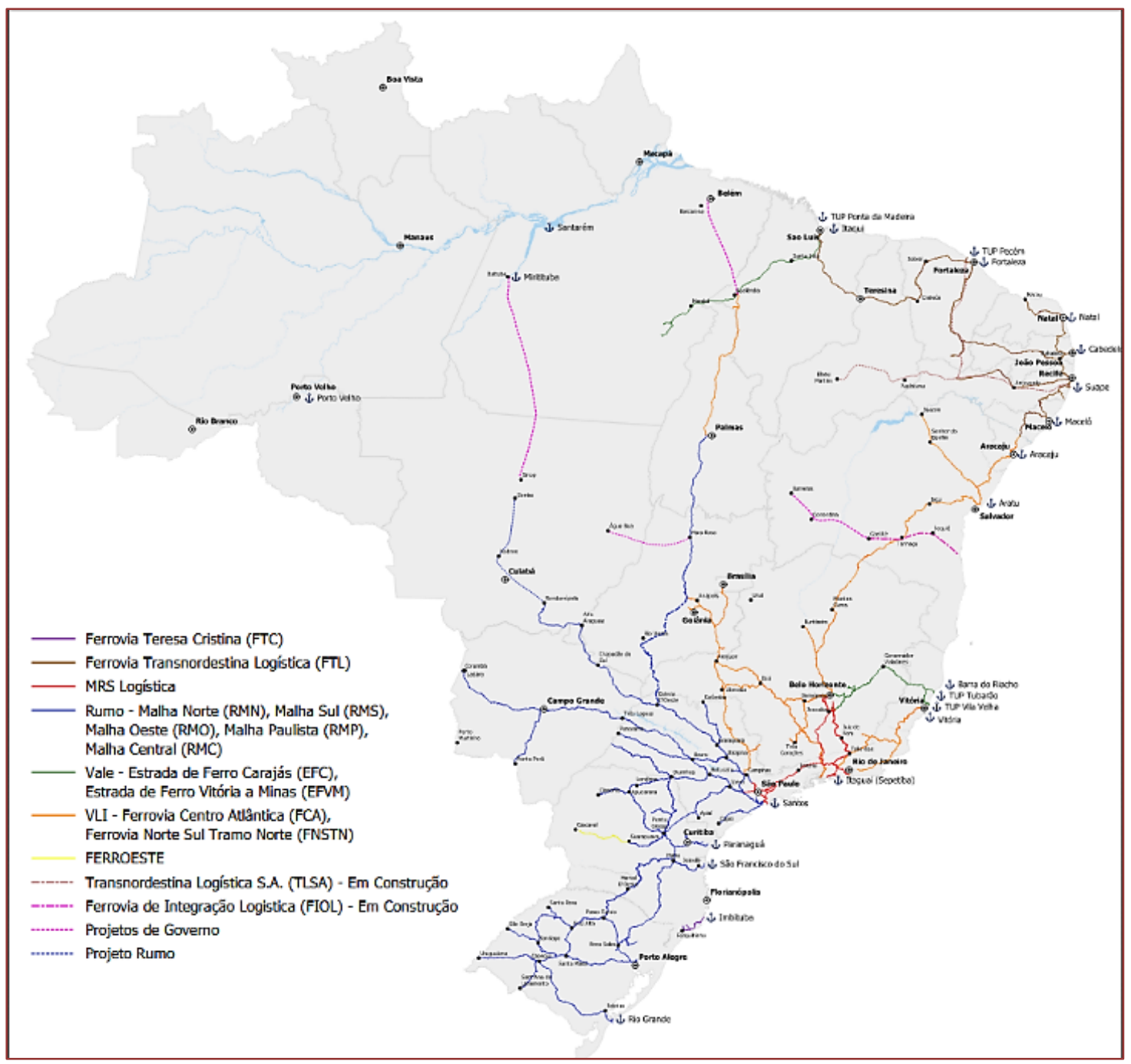

Fonte: ANTF (2019)

Atualmente, a malha ferroviária do Porto de Santos é administrada pelas empresas: Rumo (Malha Norte, Malha Sul, Malha Oeste, Malha Paulista e Malha Central), M.R.S. Logística e VLI - Ferrovia Centro Atlântica (FCA). Existe também a malha da Companhia Paulista de Trens Metropolitanos (CPTM), que atualmente tem alguns de seus trechos desativados e em fase de estudo para reativação do transporte de passageiros. As malhas PORTOFER e Ferrovias Bandeirantes S/A (FERROBAN) são administradas pela Rumo. Já as malhas Perequê-Valongo e MRS são concessões da M.R.S. Logística S/A. Devido a esta divisão, se faz necessária a obtenção do direito de passagem pela concessionária administradora de cada trecho, gerando burocracia e lentidão no processo.

Dados da ANTF, mostram que o funcionamento dessas linhas é realizado da seguinte maneira: A empresa Rumo tem seus trilhos cobrindo os estados de São Paulo, Mato Grosso, Mato Grosso do Sul, Paraná, Santa Catarina e Rio Grande do Sul. E a M.R.S. opera saindo de São Paulo passando por Minas Gerais e Rio de Janeiro. A VLI não tem acesso direto ao cais, mas opera em parceria com a Rumo. 
Outra dificuldade de acesso da malha ferroviária no Porto de Santos é o gargalo rodoferroviário gerado pela falta de estacionamento para os caminhões, que provoca engarrafamentos que impactam a linha férrea.

\subsection{PROJETOS}

De acordo com ANTF, os investimentos em ferrovias entre os anos de 1997 e 2019 foram de aproximadamente R $\$ 113$ bilhões, contribuindo para um aumento de 194\% no número de locomotivas e $163 \%$ no número de vagões. Já a Confederação Nacional dos Transportes - CNT, projetos que visam a diminuição de problemas como, limitada extensão e a concentração de rotas nas regiões Centro-Sul e litorânea, problemas de traçado, com trechos sinuosos ou montanhosos, e de integração em decorrência dos diferentes tipos de bitola utilizadas na construção da infraestrutura, invasões de faixas de domínio, a tabela a seguir mostra os valores estimados em 2018 para solução desses problemas.

Tabela 1 Investimento Necessário

\begin{tabular}{|lr|}
\hline Categorla & Investimento (R\$) \\
\hline Construção de ferrovias & $307.905 .386 .271,15$ \\
\hline Construçāo de TAV & $166.029 .271 .168,16$ \\
\hline Duplicaçāo de ferrovias & $2.124 .589 .878,22$ \\
\hline Eliminação de gargalos & $2.211 .014 .353,97$ \\
\hline Recuperaçāo de ferrovias & $53.701 .100 .203,31$ \\
\hline Total Geral & $531.971 .361 .874,81$ \\
\hline
\end{tabular}

Fonte: CNT (2018)

Parte desses investimentos seriam utilizados para soluções de problemas ambientais e estruturais tais como: expansão da malha ferroviária, eliminação de gargalos, preservação da faixa de domínio, antecipação de prorrogação de contratos, promoção de uma politica de desoneração do diesel, redução de burocracia e fomento do uso desse modal, um projeto ambicioso que engloba parte das propostas da CNT seria o Ferroanel, que atualmente está paralisado.

\subsubsection{FERROANEL}

De acordo com o MInfra (Ministério da Infraestrutura), em janeiro de 2019, o governador do estado de São Paulo, João Dória e o ministro da Infraestrutura, Tarcísio Freitas assinaram um protocolo de intenções para viabilizar a concessão ferroviária e dar início às obras do trecho Norte do Ferroanel. A obra está estimada em $\mathrm{R} \$ 3,5$ bilhões, por parte do governo federal. Mesmo com a aprovação do governador do estado o projeto do Ferroanel Norte está paralisado, pois a M.R.S., empresa que detém a concessão atual dos trilhos, notou a necessidade de realizar uma obra de segregação do transporte de cargas e passageiros anterior ao empreendimento, no trecho que interliga as cidades de Jundiaí a São Paulo. 
Segundo a DERSA (Desenvolvimento Rodoviário S.A.), o Ferroanel Norte terá $53 \mathrm{~km}$ de extensão, atravessando os municípios de São Paulo, Guarulhos, Arujá e Itaquaquecetuba, seguindo o traçado do Rodoanel, possibilitando que os trens de carga tenham uma via exclusiva. Dos $53 \mathrm{~km}$ do ferroanel, $12 \mathrm{~km}$ são relativos a 42 pontes e viadutos, $17 \mathrm{~km}$ são túneis e $23 \mathrm{~km}$ em terraplanagem. Entre outros benefícios, ele proporcionará a movimentação de cargas do interior do estado para o Porto de Santos, a retirando em médio prazo de 2.800 á 7.300 caminhões diários e o aumento na movimentação de milhões de toneladas de cargas.

Após a sua implementação, que ainda não tem data definida, os trens de carga que hoje compartilham os trilhos com os trens de passageiros da CPTM serão desviados para ramais exclusivos de cargas, permitindo a redução de intervalo dos trens de passageiros e o aumento da capacidade de carga. Com a segregação dos dois tipos de transportes a obra permitirá um aumento no volume de cargas em aproximadamente 67 milhões de toneladas por ano até 2040 (Dados DERSA). Hoje o volume está em torno de 10\% desse valor, pois $84 \%$ do transporte de cargas realizado no estado é feito através do transporte rodoviário.

O Ferroanel Norte ligará o interior do estado de São Paulo ao Porto de Santos. A nova linha vai interligar a malha ferroviária da Central do Brasil, a antiga linha São Paulo/Rio de Janeiro, com a malha da linha Santos/Jundiaí. Hoje em dia os trens de carga que vem da região de Campinas e do Centro-Oeste do país passam por dentro da capital, na estação da Luz. É uma situação que se torna cada vez mais difícil, pois os trens de passageiros que antigamente transportavam 700 mil pessoas viagem/dia, hoje transportam 3 milhões de passageiros viagem/dia, o que torna urgente a necessidade de retirar a passagem dos trens de carga da capital do estado.

\subsubsection{NOVO MODELO DE GESTÃO}

Igual ocorre com o Porto de Santos, que atualmente passa pelo estudo de desestatização, as linhas férreas do porto poderão ter o mesmo destino, ou então uma das projeções seria a criação de uma Sociedade de Propósito Especifico - SPE, em entrevista ao portal de notícias G1, o atual ministro da infraestrutura Tarcísio Gomes de Freitas disse:

Dependendo de como for, vamos na linha da SPE, onde todos os operadores ferroviários serão sócios da SPE. Nós vamos estabelecer as regras de governança, de investimento e equação tarifária para a gestão. Eles serão os responsáveis pelo investimento, pela gestão da empresa e também pela questão da tarifa.

(FREITAS; Tarcísio, 2020).

O mesmo ainda ressaltou que caso a proposta de SPE não avance a segunda medida será a inclusão das linhas férreas nos lotes de leilões do porto. Com essa medida é previsto o fim do atual arrendamento da Portofer, e a adoção de um destes novos modelos para o ano de 2022. 


\subsubsection{NOVOS INVESTIMENTOS}

0 governo estadual anunciou recentemente o investimento de $\mathrm{R} \$ 6$ bilhões na reestrutura da malha ferroviária do estado de São Paulo. De acordo com reportagem do G1, o projeto de retomada $21 / 22$ será realizado pela RUMO logística, atendendo 72 municípios e beneficiando o principal corredor de granel vegetal do pais. Entre as etapas do projeto é previsto a reativação de ramais, como: Colômbia-Pradópolis (185,6 km) e Panorama-Bauru (369,1 km), que cortam o estado em direção ao Porto de Santos, dados do G1.

Para a autoridade portuária, o novo PDZ prevê um aumento de 91\% da participação ferroviária, os investimentos para a melhoria desse modal junto do rodoviário está estimado em R $\$ 2$ bilhões. Segundo noticia vinculada pela Gazeta do Povo, pretendesse alcançar um incremento de $50 \%$ na capacidade de movimentações do porto.

Imagem 3 Projeção de demanda e capacidade

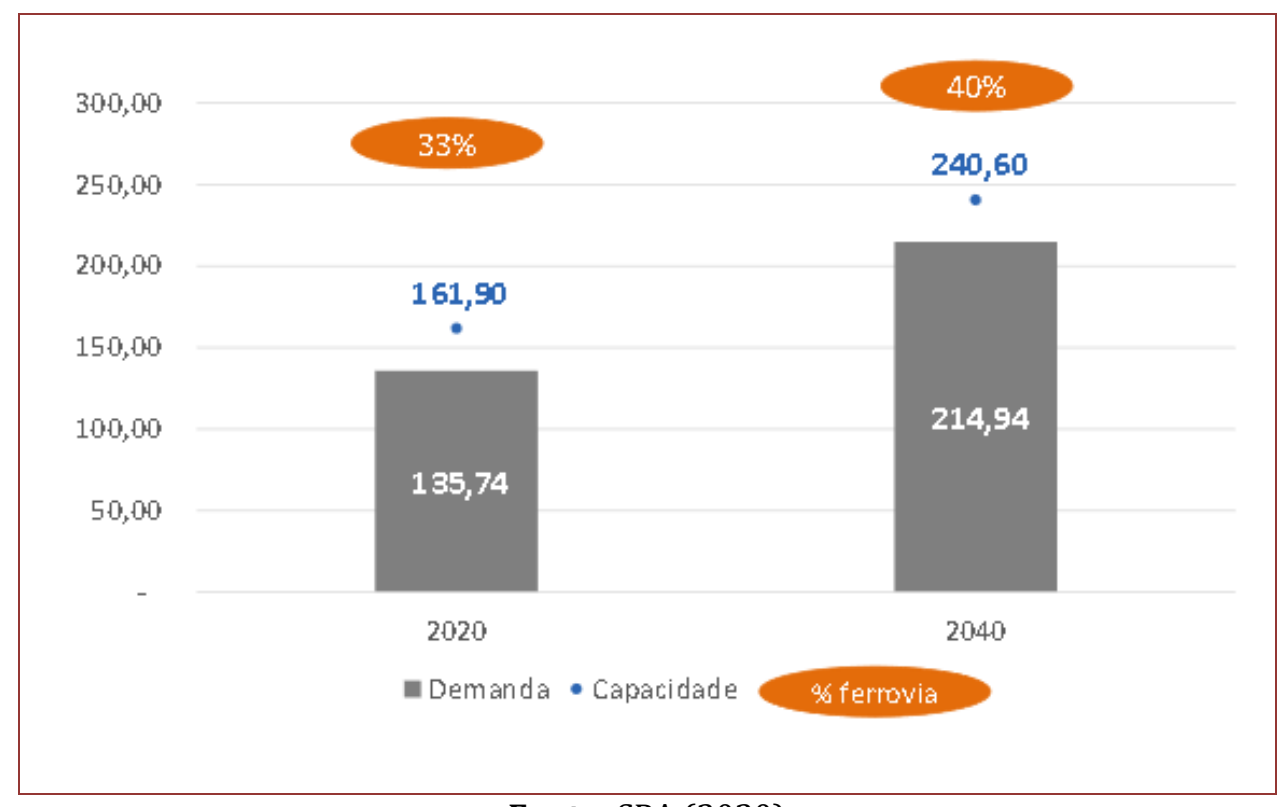

Fonte: SPA (2020)

Existem no atual PDZ outros projetos de melhorias logísticas que afetariam positivamente o modal ferroviário, como a construção de viadutos, instalação de pátios ferroviários e criação de novas peras ferroviárias. 
Imagem 4 Investimento logísticos no Porto de Santos

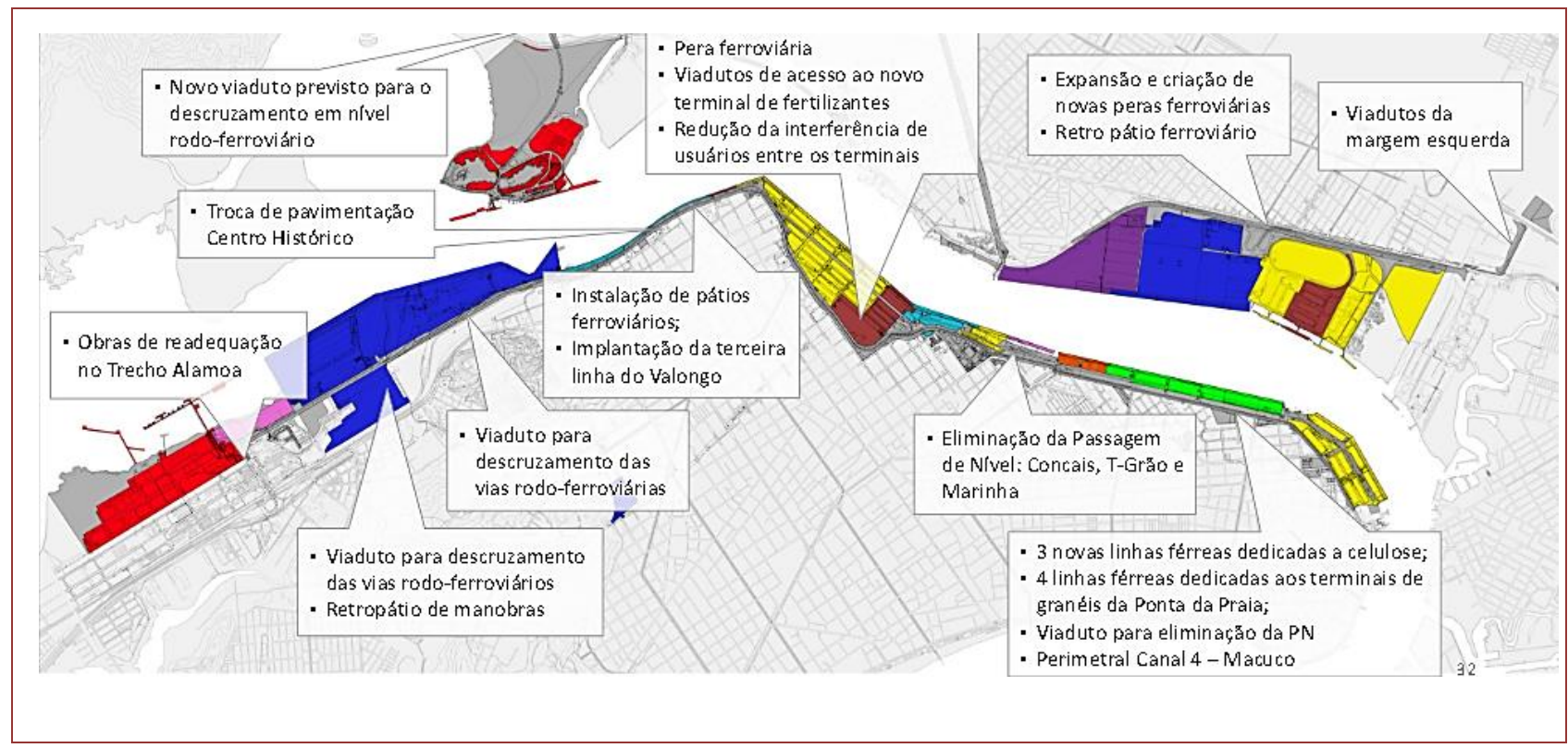

Fonte: SPA (2020)

Ainda de acordo com a SPA, os projetos previsto para o porto de santos com a finalidade de otimizar o modal ferroviário são: Revitalização da Malha Ferroviária, Remodelação do sistema ferroviário da região entre o canal 4 e a Ponta da Praia, Modernização do Pátio e dos Acessos ao Corredor de Exportação, Extensão de Linha para Estacionamento de Vagões Vazios do Terminal T-Grão, Isolamento da faixa de domínio da Portofer, Extensão da Haste de Manobra de vagões vazios em Outeirinhos/ $1^{\underline{a}}$ Fase do Projeto da $3^{\mathfrak{a}}$ linha do Paquetá, Ampliação de Linhas Férreas do Pátio de Conceiçãozinha, Adequação da Pera TGG/Termag.

\subsubsection{NOVOS CONTRATOS DE CONCESSÃO}

De acordo com reportagem feita pelo site de noticias G1, a companhia ferroviária RUMO e a ANTT assinaram um novo contrato de concessão, aumentando a capacidade de movimentação de 35 milhões para 75 milhões. 0 valor pago por esse aditivo se aproxima do montante de R\$2,9 bilhões, com previsão de termino para 2058. Para o ministro da infraestrutura Tarcísio Gomes de Freitas, em webinar realizada pela própria rumo, essa ação faz parte do movimento de criação de novas formas de investimento e ampliação da malha ferroviária.

Ainda de acordo com a reportagem a ferrovia será responsável pelo escoamento de grande parte da safra de grãos do Centro-Oeste até o Porto de Santos, ampliando a participação do Brasil no comércio global. 0 investimentos previsto pela RUMO estão próximos dos $\mathrm{R} \$ 6$ bilhões que proporcionara a movimentação de 100 milhões de toneladas úteis, atualmente o valor movimentado é de apenas 40 milhões de toneladas úteis.

\subsection{COMPARAÇÕES LOGÍSTICAS}

De acordo com estudos feitos pela Fundação Dom Cabral - FDC em 2018, os custos logísticos chegam a representar $12 \%$ dos custos de uma companhia, totalizando de maneira nacional o montante de R \$ 15,5 bilhões. Parte desse valor pode ser atribuído a 
uma má gestão logística, problemas estruturais e a centralização em um único modal de transporte, o modal rodoviário. De acordo com reportagem feita pelo portal de noticias Terra com dados do Departamento Nacional de Infraestrutura de Transportes - DNIT, apenas 13\% dos atuais 221820 quilômetros de rodovias são pavimentados.

Frente a estes problemas, o modal ferroviário apresenta um baixo custo operacional e pequeno consumo de combustível em relação ao transporte rodoviário. De acordo com a Prestex, empresa do ramo de fretamento, o transporte ferroviário é uma opção adequada para cargas de grandes volumes e que percorrem longas distâncias. Outro benefício apresentado é o seu baixo custo se e capacidade para transportar grandes volumes e pesos, Para um pais exportador de commodities como o Brasil, sua maior utilização seria ideal para aumento da quantidade movimentada como minério de ferro, produtos siderúrgicos, derivados do petróleo, fertilizantes, mercadorias agrícolas, entre outros.

De acordo com dados do canal rural, somente $25 \%$ da produção brasileira oriunda da agricultura e agropecuária é transportada pelo modal ferroviário, já de acordo com plano nacional logístico - PNL, a participação ferroviária de maneira geral é de apenas $15 \%$.

Imagem 5 Participação dos modais de transporte

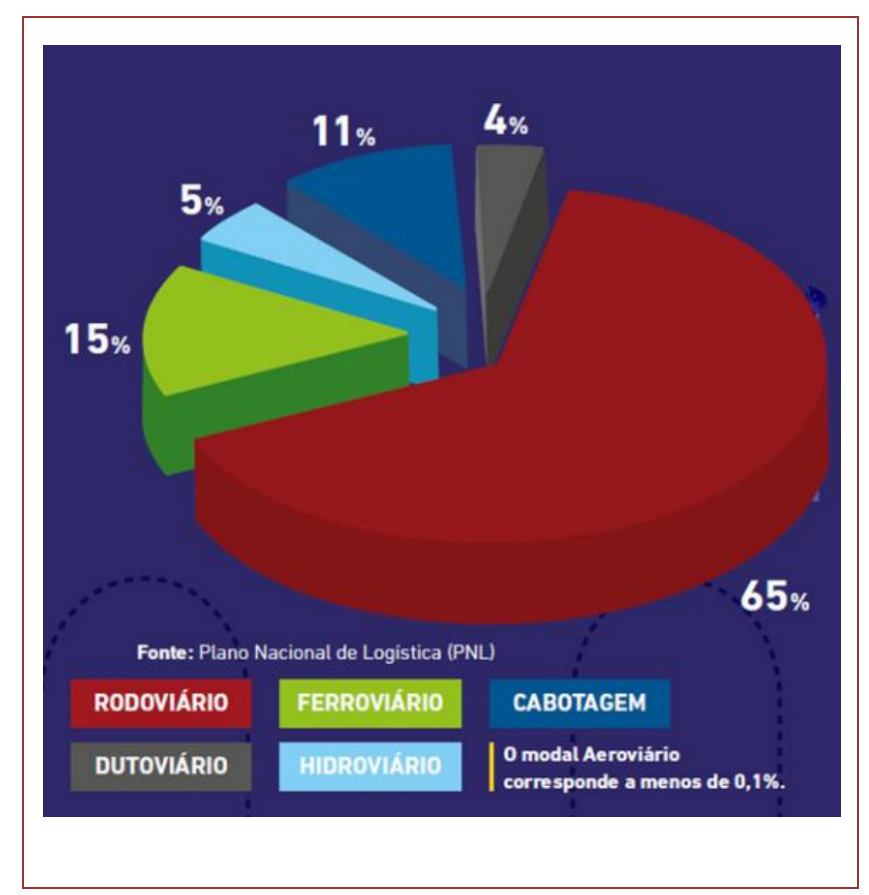

Fonte: PNL (2018)

De acordo com dados da Confederação Nacional dos Transportes - CNT, o tempo de vida útil de um trem é de 35 anos enquanto o de um caminhão é de 8 anos. Esse dado é importante para entendermos o porquê do custo logístico no Brasil ser tão elevado. Segundo dados do anuário estatístico da CNT, o transporte de cargas cresceu 8,5\% entre os anos de 2017 e 2018, em TEU's (Twenty Foot Equivalent Unit) esse aumento representou 5,8\% nas movimentações.

De acordo com matéria da Porto Gente, as principais desvantagens do modal rodoviário estariam relacionados aos custos de fretamento, capacidade de movimentação de carga reduzida, poluição atmosférica, e as constantes faltas de manutenção da malha 
rodoviária. Já a Associação Brasileira da Indústria Ferroviária - ABIFER mostra que a cada quilometro rodado os caminhões chegam a consumir 13 vezes mais energia do que um trem transportado 1 tonelada. 200 vagões chegam a transportar o mesmo que 400 carretas rodoviárias. Esses números dão mostra que um trem quando operado em sua carga máxima pode chegar a retirar das estradas 280 caminhões. Além dos custos rodoviários serem aproximadamente 6 vezes maiores que os ferroviários.

\subsection{MATRIZ LOGÍSTICA INTERNACIONAL}

O desbalanceamento da matriz logística não é beneficia ao porto de Santos. A dependência do modal ferroviário acarreta uma série de custos extras conforme mencionado anteriormente. De acordo com o Instituto de Logística e Supply Chain ILOS, os países mais eficientes logisticamente são os que apostaram em uma matriz mais balanceada, e uma intermodalidade eficiente, como é possível analisar na imagem 6.

Imagem 6 Matriz logística

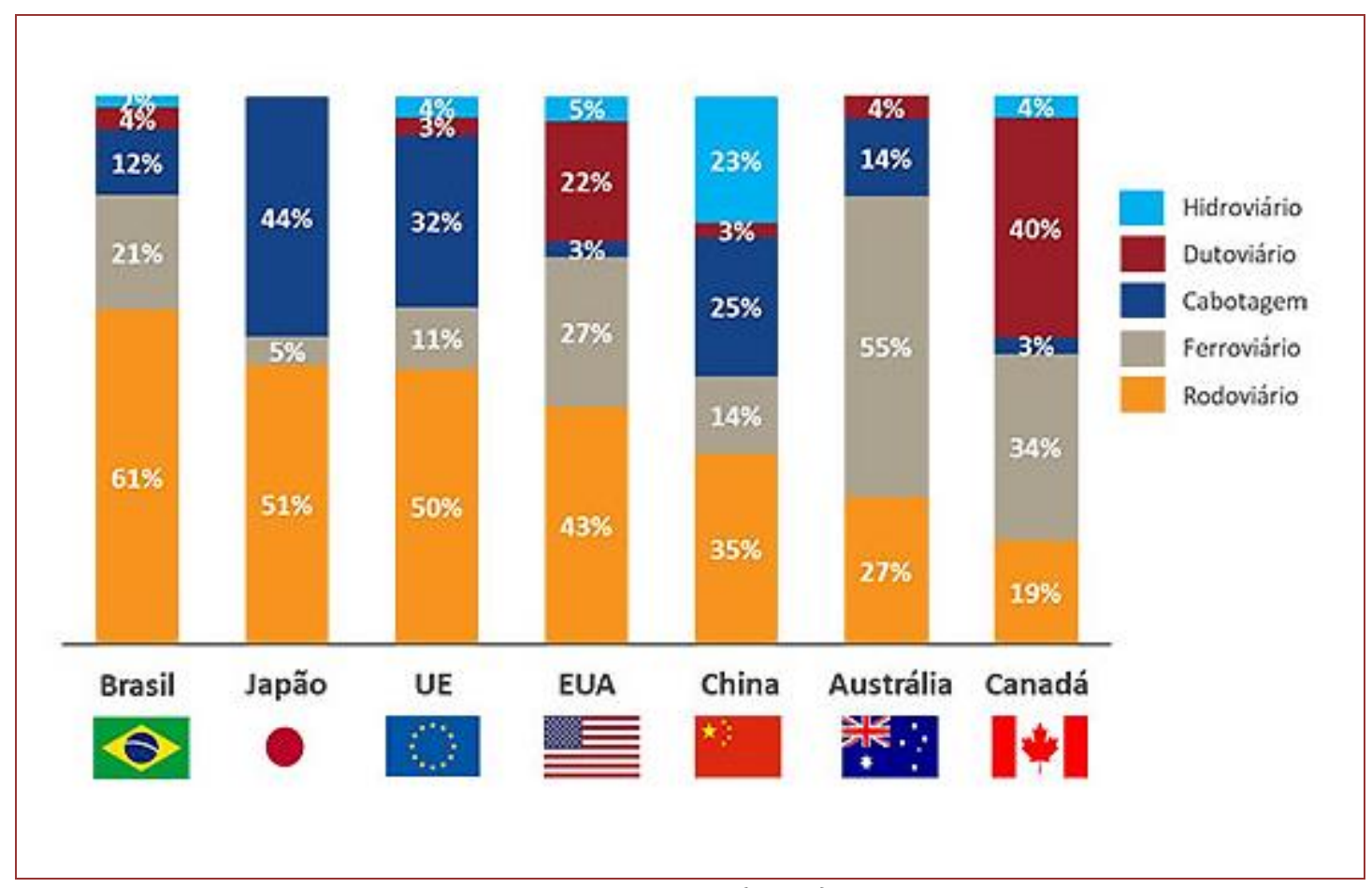

Fonte: ILOS (2020)

Parte da necessidade da aposta no modal ferroviário se dá pelo fato da falta de infraestrutura da cadeia rodoviária, dados da própria ILOS dão mostra que comparado a países como Alemanha, China, Índia, Rússia e Estados Unidos, nós possuímos a apenas 213 mil quilômetros de rodovias pavimentadas a menor 30 mil quilômetros de ferrovias. 0 modal predominante no Brasil é justamente o que traz mais custos logísticos para o escoamento de carga. De acordo com a própria ILOS, o Brasil exporta em maiores quantidades minério de ferro, soja, milho e açúcar, que por sua vez são produtos de que exigem grandes volumes, e possuem pouco valor agregado, com isso torna-se vantajoso uma participação maior do modal ferroviário. 


\section{RESULTADOS E DISCUSSÃO}

Os países mais desenvolvidos adotaram a utilização desse modal para o transporte em grandes quantidades de produtos com baixo valor agregado, isso proporciona ganhos logísticos e econômicos para eles, ao contrário de nós, que temos uma intermodalidade deficitária, baixo investimento na construção de ferrovias, fazendo nossos produtos absorverem grandes gastos logísticos que poderiam ser evitados.

Segundo informações divulgadas pelo MInfra no início deste ano, a previsão inicial dos próximos investimentos para a criação de linhas férreas é de 40 bilhões de reais. A seguir falaremos destes projetos que, após a sua finalização, permitirão que o escoamento de cargas seja aperfeiçoado em diversas regiões do país.

Com esses dados é importante para o porto de Santos se manter eficiente logisticamente, atualmente existem projetos em demais portos com o objetivo de aumento da capacidade de movimentação como o Ferrogrão ligando a região Centro-Oeste ao Porto de Miritituba no estado do Pará, e o Ferroeste ligando o estado do Mato Grosso do Sul com o porto de Paranaguá. 0 porto de Santos necessita se atualizar na mesma proporção para continuar a ter sua relevância no cenário nacional.

Portos que recebam este tipo de investimento tendem a roubar demanda do porto de Santos, vale ressaltar dois exemplos como o porto de Itaguaí - RJ, onde seu calado 5 metros maior que o de Santos pode se beneficiar com o rodoanel e receber um volume maior de graneis sólidos, o outro estaria diretamente ligado com o projeto do Ferrogrão que beneficiaria os portos do arco norte devido a sua proximidade com a América do Norte e a Europa.

De acordo com dados do anuário da ANTAQ, o porto de Santos exportou no último ano cerca de 52310573 toneladas de cargas a granel, considerando as atuais projeções do novo PDZ apenas 33\% dessa carga chegou ao porto por meio ferroviário, isso mostra o quão pode ser o crescimento desse modal para o porto, e como ele pode auxiliar na otimização da carga e no barateamento dos seus custos. pois levando em consideração $67 \%$ desse carregamento sofreu com os custos elevados oriundos do modal ferroviário como: frete, seguro, má condição das nossas estradas, menor capacidade de transporte por viagem entre outros fatores.

Tendo em vista esses dados, é importante destacar a aposta na intermodalidade, pois o modal ferroviário tem limitações que impactariam a cadeia logística, esse modal possui rotas fixas, não fazendo um serviço de porta a porta. Outro fator importante, a aposta na intermodalidade e uma melhor utilização do modal ferroviário é fundamental para ganhos logísticos e econômicos, com a redução nas tarifas de frete o produto chegara ao seu destino, sendo ele o mercado externo ou interno, com preços mais competitivos. Fazendo com que o mercado de maneira geral seja beneficiado e com isso o pais acabe por sua vez arrecadando mais.

\section{CONSIDERAÇÕES FINAIS}

O objetivo principal deste estudo levantar os principais projetos, ou movimentos de melhoria do modal ferroviario, em especial projetos como Ferroanel ou novos modelos de investimentos, que visam otimizar o uso desse modal trazendo ganhos técnicos e economicos. Com isso de maneira geral fica claro os ganhos que a utilização eficiente da matriz ferroviaria tem a oferecer ao Porto de Santos, e ao pais de maneira geral. Pois 
embora sua implementação seja mais cara, sua utilização acarreta na diminuição de custos logisticos, fazendo, trazendo maior competitividade ao Brasil.

Esse artigo não tem como objetivo a analise, custos e demais fatores importantes para implementação desse modal, ou de politicas que melhorem o modal rodoviario. Limitando apenas aos dados de ganhos e comparativos já existentes. Cabendo então a realização de estudos futuros para a aplicação dos demais itens aqui levantados.

\section{REFERÊNCIAS}

[1]. SPA - Santos Port Authority. Acesso Ferroviário. Disponível em:

http://www.portodesantos.com.br/infraestrutura/acesso-ferroviario/. Acesso em: 14 set. 2020.

[2]. ANTF - Associação Nacional dos Transportadores Ferroviários. Mapa Ferroviário. Disponível em: https://www.antf.org.br/mapa-ferroviario/. Acesso em: 14 set. 2020.

[3]. DERSA - Desenvolvimento Rodoviário S.A.. Ferroanel Norte. Disponível em: http://www.dersa.sp.gov.br/empreendimentos/ferroanel-norte/. Acesso em: 14 set. 2020.

[4]. PRODANOV, C.R \& FREITAS, E.C. Metodologia do Trabalho Científico: Métodos e Técnicas da Pesquisa e do Trabalho Acadêmico. $2^{\underline{a}}$ ed. Novo Hamburgo/RS: Universidade Fevale, 2013.

[5]. ABIFER - Associação Brasileira da Indústria Ferroviária. Transporte ferroviário: há futuro para uma logística mais eficiente e com mais qualidade? Disponível em:

https://abifer.org.br/transporte-ferroviario-ha-futuro-para-uma-logistica-mais-eficiente-e-commais-qualidade/. Acesso em: 10 out. 2020.

[6]. CANAL RURAL. Entenda por que o brasil e tão dependente do transporte rodoviário. Disponivel em: https://www.canalrural.com.br/programas/informacao/rural-noticias/entendapor-que-o-brasil-e-tao-dependente-do-transporte-rodoviario/s. Acessado em: 10 out. 2020

[7]. EPL - EMPRESA DE PLANEJAMENTO LOGISTICO. Plano nacional de logística PNL. Disponível em: https://www.epl.gov.br/plano-nacional-de-logistica-pnl. Acessado em 20 out. 2020

[8]. BALLOU, R.H. Gerenciamento da cadeia de suprimentos/logística empresarial 5 ${ }^{\mathbf{a}}$ ed. Porto Alegre/RS Bookman, 2006

[9]. VALENTE, A.M. Passaglia, E. Cruz, J.A. Mello, J.C. Carvalho, N.A. Mayerle, S. Santos, S. Qualidade e Produtividade nos Transportes 1a ed. São Paulo/SP Cengage Learning, 2008

[10]. ROSA, R.A. Operação Ferroviária 1a ed. Rio de Janeiro/RJ LTC 2016

[11]. G1. Serviço ferroviário terá novo modelo de gestão no porto de santos. Disponível em: https://g1.globo.com/sp/santos-regiao/porto-mar/noticia/2020/08/27/servico-ferroviariotera-novo-modelo-de-gestao-no-porto-de-santos-sp.ghtml. Acessado em 20 out. 2020

[12]. GAZETA DO POVO. Porto de santos quer ampliar entrega da matriz ferroviária em 91 Gazeta do Povo. Disponível em: https://www.gazetadopovo.com.br/agronegocio/porto-desantos-quer-ampliar-entrega-da-matriz-ferroviaria-em-91/. Acessado em: 20 out. 2020

[13]. PORTO DE SANTOS. PDZ Apresentação. Disponível em:

http://www.portodesantos.com.br/wp-content/uploads/2020/06/pdzapresentacao.pdf. Acessado em: 01 nov. 2020

[14]. G1. Novo contrato de concessão da malha ferroviária ampliara capacidade de transporte de carga com destino ao porto de santos. Disponível em: https://g1.globo.com/sp/santosregiao/porto-mar/noticia/2020/05/29/novo-contrato-de-concessao-da-malha-ferroviariaampliara-capacidade-de-transporte-de-carga-com-destino-ao-porto-de-santos.ghtml. Acessado em: 02 nov. 2020 
[15]. PAC - PROGRAMA DE ACELERAÇÃO DO CRESCIMENTO. Ferrovias. Disponível em: http://pac.gov.br/infraestrutura-logistica/ferrovias. Acessado em 02 nov. 2020

[16]. VALEC. Ferrovia de integração oeste leste. Disponível em: https://www.valec.gov.br/ferrovias/ferrovia-de-integracao-oeste-leste. Acessado em 03 nov. 2020

[17]. PPI - PARCERIA PUBLICO PRIVADO. Ferrovia de integração oeste leste. Disponível em: https://www.ppi.gov.br/ferrovia-ef-334ba-ferrovia-de-integracao-oeste-lest-fiol. Acessado em: 09 nov. 2020

[18]. PPI - PARCERIA PUBLICO PRIVADO. Ferroeste. Disponível em: https://www.ppi.gov.br/ferroeste1 Acessado em: 09 nov. 2020

[19]. PPI - PARCERIA PUBLICO PRIVADO.. Ferrogrão. Disponível em: https://www.ppi.gov.br/ef-170-mt-pa-ferrograo. Acessado em 09 nov. 2020

[20]. TERRA. Brasil tem apenas 13 das estradas pavimentadas Disponível em: https://www.terra.com.br/noticias/brasil/estradas/brasil-tem-apenas-13-das-estradaspavimentadas,7474a9670cb9f1e0180774a18f84b1ca5dzs3j5k.html. Acessado em: 09 nov. 2020

[21]. FDC - FUNDAÇÃO DON CABRAL. Custo Logístico Disponível em: https://www.fdc.org.br/conhecimento/publicacoes/relatorio-de-pesquisa-33324. Acessado em: 09 nov. 2020

[22]. PRESTEX. Modais de Transporte de carga no Brasil conheça os 5 principais. Disponível em: https://www.prestex.com.br/blog/modais-de-transporte-de-carga-no-brasil-conheca-os-5principais/. Acessado em: 09 nov. 2020

[23]. ABIFER - ASSOCIAÇÃO BRASILEIRA DA INDUSTRIA FERROVIÁRIA. Logística trem versus caminhão. Disponível em: https://abifer.org.br/logistica-trem-versus-caminhao/. Acessado em: 09 nov. 2020

[24]. PORTO GENTE. Transporte Rodoviário. Disponível em: https://www.portogente.com.br/portopedia/73414-transporte-rodoviario. Acessado em: 10 nov. 2020

[25]. ILOS - INSTITUTO DE LOGISTICA E SUPPLY CHAIN. Matriz de Transporte no Brasil espera investimentos Disponível em: https://www.ilos.com.br/web/matriz-de-transportes-dobrasil-a-espera-dos-investimentos/ Acessado em 10 nov. 2020

[26]. ILOS - INSTITUTO DE LOGISTICA E SUPPLY CHAIN. Perspectivas para a infraestrutura brasileira. Disponível em: https://www.ilos.com.br/web/perspectivas-para-a-infraestruturabrasileira/. Acessado em 10 nov. 2020 


\section{Capítulo 7}

\section{Transporte de carga perigosa: Nitrato de amônia}

\section{Daniel de Carvalho \\ Guilherme Tavares Gama \\ Jessica Motta Gonçalves Henrique}

Resumo: A pesquisa científica tem como objetivo mostrar a importância e os cuidados necessários para a movimentação da carga perigosa amônia em segurança, a qual é utilizada como base química para diversos produtos químicos, como produtos de higiene, limpeza, farmacêuticos, compostos de fertilizantes, entre outros. Diariamente uma grande quantidade de nitrato de amônia é transportada e armazenada, assim sendo, este trabalho visa possibilitar o controle e a prevenção de acidentes de acordo com normas de segurança atuais.

Palavras-chave: Amônia 1. Produtos químicos 2. Prevenção de acidentes 3. 


\section{INTRODUÇÃO}

A amônia é um produto químico perigoso capaz de causar sérios danos à saúde e ao meio ambiente e é utilizada na fabricação de fertilizantes agrícolas, fibras e plásticos, produtos de limpeza, explosivos, entre outros. Conforme site Valor Econômico, no ano de 2017 ocorreu um vazamento de amônia na empresa Citrosuco, localizada na Cidade de Santos/SP; devido ao rompimento da válvula de segurança o que gerou o vazamento do gás, o problema foi sanado após o fechamento dos dutos, porém o acidente resultou em duas pessoas feridas. Devido os acidentes causados no Porto de Santos por causa do produto químico amônia, empresas da região e a autoridade Portuária organizaram um evento para informar e orientar a população a respeito da segurança da manipulação do produto e orientar em relação aos procedimentos em caso de suspeita de vazamento.

A movimentação de amônia deve ser executada com responsabilidade e dentro dos critérios determinados pelas normas relacionadas ao transporte de cargas perigosas, visto que muitas indústrias sofrem prejuízos financeiros devido ao vazamento deste gás que gera multas por ser um produto prejudicial à saúde e ao meio ambiente. Segundo site Gazeta Web, o Brasil importa cerca de 1 milhão de toneladas de nitrato de amônio por ano. Várias normas e cuidados específicos devem ser levados a sério quando falamos de transporte/movimentação de carga perigosa, pois existem grandes riscos na movimentação destes produtos. A falta de inspeção e manutenção dos equipamentos, recipientes que transportam esses produtos podem causar acidentes. Alguns desses episódios causados pelo vazamento de amônia acabam gerando multas para indústrias e terminais portuários, assim como danos à saúde de trabalhadores e moradores das regiões afetadas pelo vazamento do gás.

O objetivo deste trabalho de pesquisa é estudar a movimentação da carga perigosa amônia, buscando conhecer os cuidados necessários para transportar e movimentar produtos capazes de causar sérios danos as pessoas e ao meio ambiente, assim como, identificar e apresentar instruções de segurança eficazes para a movimentação deste produto, possibilitando ações preventivas e um menor prejuízo a vida humana e ao meio ambiente. Este trabalho de pesquisa baseia-se em padrões e metodologias específicas para uma pesquisa científica, utilizando-se da revisão bibliográfica, análise qualitativa e análise quantitativa.

O estudo bibliográfico é desenvolvido a partir livros e artigos científicos, já elaborados. Grande parte dos estudos exploratórios é desenvolvida a partir de fontes bibliográficas e são importantes para o surgimento de novas pesquisas empíricas. Permite ao pesquisador cobrir uma gama maior de fenômenos. Como principal desvantagem, destaca-se o risco da apresentação de dados com baixa qualidade (GIL, 1999).

\section{FUNDAMENTAÇÃO TEÓRICA OU REVISÃO DA LITERATURA}

A cadeia de suplementos (SCM gerenciamento da cadeia de suplementos) surgiu como uma evolução natural do conceito de logística, que representava uma integração interna de atividades, sendo o SCM sua integração externa, abrangendo atividades com a fluidez de matérias e informações aos fornecedores e aos clientes finais ao redor do mundo. 0 Conselho de Gestão de Logística (Council of Logistic Management-CLM) defini como o processo da cadeia de abastecimento que idealiza, implementa e controla fluxo de bens e serviços e todas as informações encadeadas, do ponto de origem de consumo de forma efetiva, na busca de satisfazer às necessidades dos clientes. 
Na cadeia de suprimentos o PPCM (Planejamento-Programação-Controle-Manutenção) necessita trabalhar de forma ajustada onde as informações são disponibilizando em tempo real garantindo todo o processo produtivo e transformando rapidamente os insumos em produtos. Tal fluxo torna-se indispensável em todos departamentos de planejamento, finanças programação e controle da produção, compras, engenharia, qualidade, e produção, gerando novos contratos e responder com a máxima rapidez as necessidades dos clientes. O SCM que se dá início desde a produção, passando pelas movimentações e armazenamento e terminando no transporte, tem como objetivo diminuir custos e prazos de entregas visando um maior lucro, podemos dizer que a cadeia de suprimentos é a o conjunto de todos os recursos, tarefas, tecnologias e indivíduos relacionados à criação e venda de um produto, desde a entrega de materiais de origem do fornecedor até sua entrega ao usuário final. (Council of Logistic Management-CLM).

Sua formação compreende nos fornecedores de matéria-prima, produtores que convertem o material em produtos, e armazéns, e também nos centros de distribuição que realizam a entrega aos comércios e varejistas que propiciam o produto ao cliente final. A relevância da cadeia de suprimentos ocorre pela capacidade de oferecer aos clientes o que desejam, no tempo e espaço correto e com produtos e serviços pelo preço em que estão dispostos a pagar, por intermédio de uma cadeia de suprimentos eficiente que se torna viável a garantia da competitividade da empresa perante o mercado. (Council of Logistic Management-CLM).

Trata-se de uma rede de empresas dependentes entre si, que trabalham em cooperação afim de manter um fluxo apropriado de matérias-primas e informações entre fornecedores e clientes finais (CHRISTOPHER,1999). Concentre-se nas necessidades reais do cliente, sincronize operações em toda a empresa, substitua ativos por informações, elimine a repetição de esforços e o desperdício. Essas são as receitas para criar uma cadeia de fornecimento (ou supply chain) integrada, colaborativa, adaptativa e virtual (KEARNEY, 2004, p.128).

Para obter uma gestão da cadeia de suprimentos mantém-se o equilíbrio entre fornecimento e demanda, garantindo a regularidade entre a aquisição de materiais e a conversão em produtos acabados, garantindo assim a entrega no momento correto. Contudo, o adequado gerenciamento da cadeia de suprimentos acaba que por melhorar o relacionamento com o cliente, assim como é capaz de reduzir os custos operacionais. Fazem parte da Cadeia de Suprimentos:

> Gestão de recursos: Matérias-primas são consumidas em toda produção bem como o uso da mão-de-obra em todos os processos, que devem ser eficazes e eficientes e com a produção otimizada e custos controlados.

$>$ Operações: Planejamentos e previsão da demanda controlados pela equipe de operações, onde a demanda é prevista antes que se estabeleça as compras, que se são executadas com precisão.

$>$ Logística: Organização dos espaços de armazenamento até o momento final da entrega, e é responsável ainda pela garantia de que os produtos possuam imperfeições ou atrasos ao destino final. Os produtos além dos limites municipais, estaduais e federais são realizados por transportes além da necessidade de empresas possuírem armazéns outstation. 
> Compra: Muitas vezes é a primeira função dentro do gerenciamento e envolve as aquisições de matérias-primas, outros recursos essenciais na fabricação de mercadorias e dentro desta etapa exige-se uma coordenação primorosa com intuito de garantir as entregas sem atrasos dos materiais.

Fluxo de trabalho: Comunicação, compartilhamento e distribuição de informações. São cruciais pois os dados sendo ineficientes poderá ter consequências de fragmentação em toda a cadeia.

Até mesmo as cadeias de suprimentos mais simples abrangem ao menos uma empresa, clientes e fornecedores, dessa forma a disposição pode ser: produtor de matériasprimas, fabricante, distribuidor, varejista e cliente. Por sua vez, uma cadeia de suprimentos mais ampla inclui mais de um fornecedor e clientes finais, além das organizações oferecerem os serviços indispensáveis para o produto chegar aos clientes, incluindo fornecedores terceiros, financiadoras, auxílio de softwares de cadeia de suprimentos e pesquisas de marketing.

As questões operacionais e dos relacionamentos permeiam as necessidades de gerenciamento da cadeia para funcionar como uma entidade única, integrando a coordenação de aspectos funcionais internos com processos externos. Princípios que devem compor a caracterização do SCM:

Filosofia integrativa

$>$ Gerenciamento do fluxo total

$>$ Gerenciamento dos relacionamentos

$>$ Integração dos processos-chave

$>$ Agregar valor em cada elo da cadeia

$>$ Coordenação sistêmica, estratégica e tática da tradicional função dos negócios

$>$ Sincronizar as necessidades dos parceiros

$>$ Formar uma organização virtual

Os elementos da SCM são capturados em uma trilogia de coordenação das três dimensões abrange as questões da filosofia e do gerenciamento de processos e alguns autores definem SCM em termos operacionais, entre fluxo de materiais e produtos, bem como outros a definem como uma filosofia de gerenciamento e ou como um processo de gerenciamento. A partir da diversidade de visões e experiências, Mentzer et al. (2001) divide as coordenações do SCM em termos de: filosofia gerencial e gerenciamento de processos. 
FIGURA 1: As 3 dimensões do gerenciamento da cadeia de suprimentos

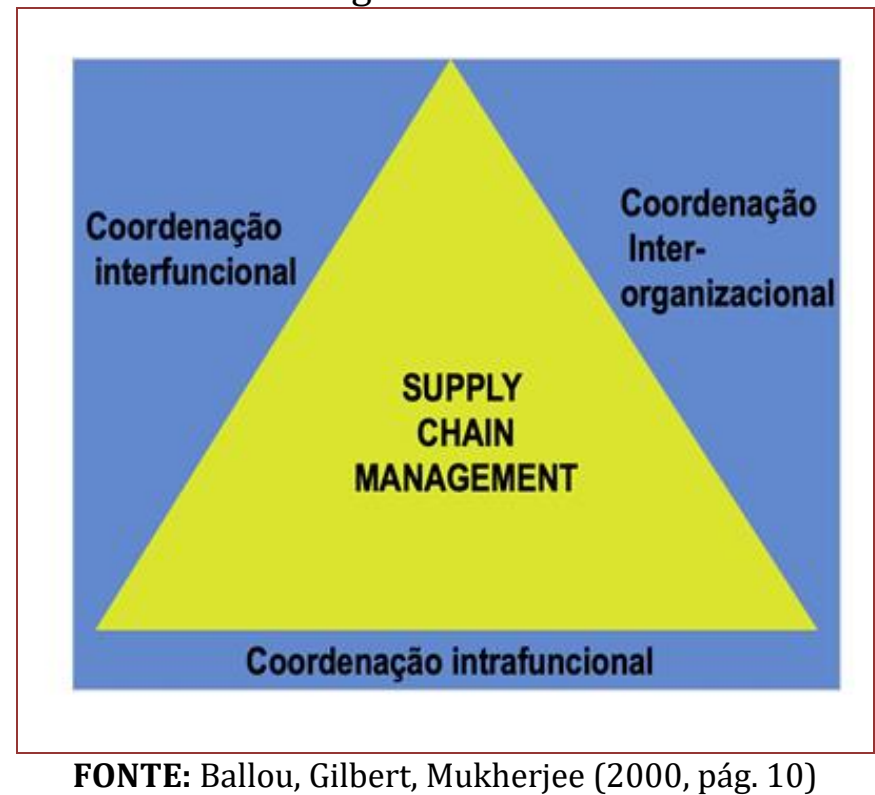

A configuração da tríade de coordenação do SCM é formada pelas coordenações de atividades interfuncionais (administração de atividades entre ofícios dentro da empresa), coordenações intrafuncionais (adiminstração das atividades e processos dentro da função logística de uma empresa), e pela coordenação de atividades interorganizacionais. A globalização, as inovações tecnológicas e a crescente competitividade têm exigido com que as organizações busquem novas formas de se manter no mercado. Dentre essas formas, encontra-se a integração da cadeia de suprimentos através do gerenciamento da cadeia de abastecimento. 0 padrão nas operações, e nas movimentações de produtos acabados, os semi-acabados e todas as matérias-primas para atendimento de vendas, produção ou demais áreas, requerem para estratégias de movimentação, estruturas de armazenagem e layout diferenciados para redução do tempo de movimentação e custos. Em nível de importância nos processos de armazenagem, o recebimento não é a etapa que tem a maior atenção, mas é nessa etapa que serão definidas informações importantes que gerarão mais velocidade na separação e maior produtividade das equipes operacionais. No recebimento, são feitas as operações de conferência por quantidade, inspeção e identificação das mercadorias. (BALLOU, 2001)

Atentando aos fluxos de informações e materiais desde aquisição até o consumidor, ou seja do ponto de início o destino final, planejando assim possibilitar níveis de serviço ajustando às necessidades dos clientes/fornecedores e a um custo competitivo. $\mathrm{Na}$ sequência segue os pontos principais das atividades primárias:

\subsection{TRANSPORTES}

A atividade de transporte está relacionada aos diversos métodos de se mobilizar produtos e insumos, portanto é essencial ao processo logístico, e ainda é responsável por uma grande parte dos custos logísticos da empresa. Em termos mundiais podemos considerar que há uma propensão à multimodalidade nos meios de transportes disponíveis: marítimo, aeroviário, dutoviário, ferroviário e rodoviário. sendo o modal rodoviário o que mais predomina em nosso país. 


\subsection{MANUTENÇÃO DE ESTOQUES}

O foco é manter um nível de estoque possível sem afetar o nível de serviço ao cliente, ou seja, dispor da quantidade necessária para atender ao cliente quando ele desejar. Contudo, existem técnicas de gestão que contribuem nesta tarefa. Em conteúdo logístico, esta atividade também é relevante, sendo então necessária atenção especial a este ponto.

\subsection{PROCESSAMENTO DE PEDIDOS}

Esta atividade está relacionada diretamente ao nível de serviço ofertado aos clientes, logo também é de extrema importância para o processo logístico. 0 grande desafio do profissional de logística consiste em reduzir o ciclo do pedido que é o tempo total entre o cliente realizar um pedido e o mesmo ser entregue. Logo, é importante contar com sistemas eficientes de recebimento de pedido, checagem de estoque, aprovação de crédito, separação, expedição e entrega do produto comprado para o cliente. A unitização de cargas para as atividades primárias (transporte, armazenagem e distribuição) tem como objetivo facilitar a movimentação, armazenagem e transporte, permitindo a redução de custos e atingindo maior produtividade e segurança suplementar. Os tipos de unitização são: pré-linguagem, paletização, big-bag e conteinerização, sendo as principais vantagens no seu uso a redução de números de volumes a movimentar, melhoria da produtividade operacional, redução de custos de embarque e desembarque, diminuição da probabilidade de roubos e avarias, com a decorrência da redução no valor dos seguros.

\subsection{CARGAS ESPECIAIS}

Definimos cargas especiais aquelas que não se delimitam nas Resoluções 12/98 e 68/98 do CONTRAN, Portaria № 23/1996 do DER-SP (AutoBan / Via Oeste) - Resolução № 11/2005 do DNIT (Nova Dutra / Rodo Norte) - Normas ABNT com ênfase na NBR 8681/2003. O DNIT é o órgão responsável pela infraestrutura de transporte no país e estabelece que os produtos de características perigosas são todos nos quais provém de origem biológica, química ou radiológica que são nocivos ao meio ambiente, população e aos seus bens. O Departamento Nacional de Infraestrutura de Transportes (DNIT), órgão responsável pela infraestrutura de transportes no país, determina que os produtos de natureza perigosa são todos aqueles de origem química, biológica ou radiológica que são nocivos ao meio ambiente, à população e aos seus bens. Ao todo são contabilizadas mais de 3 mil mercadorias que têm o potencial de gerar riscos à saúde, ao meio ambiente e à segurança pública, onde a finalidade da instituição é tornar o transporte desse tipo mais organizado e seguro.

\subsection{CARGAS PERIGOSAS}

São estipuladas cargas perigosas toda a carga que, sendo explosiva, como os gases comprimidos ou liquefeitos, oxidantes, inflamáveis, venenosas, infecciosas, corrosivas, radioativas ou poluentes, que caracterizem riscos a trabalhadores, as instalações e ao meio ambiente em geral. É exigido para a segurança do transporte e do manuseio de Cargas Perigosas a sua adequada identificação, etiquetagem, acondicionamento, empacotamento, bem como a documentação e estão de acordo com a natureza dos materiais classificadas em nove categorias: 
$>$ gases

$>$ líquidos inflamáveis

$>$ sólidos inflamáveis

> substâncias oxidantes e peróxidos orgânicos

$>$ substâncias tóxicas e substâncias infectantes

$>$ material radioativo

> substâncias corrosivas

substâncias e artigos perigosos diversos

A cadeia logística de transporte de cargas perigosas envolve diversos agentes e capacitação para lidar com materiais químicos, assim garantir a maneira mais correta de garantir um transporte seguro e eficiente para cargas perigosas.

0 produto estudado e desenvolvido a seguir é o nitrato de amônia que é considerada uma das cargas mais perigosas por oferecer perigos para humanos e ao meio ambiente no seu transporte. Diversos acidentes foram envolvidos no transporte de fertilizantes como o nitrato de amônio, que influenciaram na legislação de transporte, armazenamento e manuseio. As decomposições durante o transporte e no armazenamento podem ter causado a liberação de gases tóxicos, explosões e situações de risco.

\section{DESENVOLVIMENTO DA TEMÁTICA OU PROCEDIMENTOS METODOLÓGICOS}

O objetivo deste trabalho de pesquisa é estudar a movimentação da carga perigosa amônia, buscando conhecer os cuidados necessários para transportar e movimentar produtos capazes de causar sérios danos as pessoas e ao meio ambiente, assim como, identificar e apresentar instruções de segurança eficazes para a movimentação deste produto, possibilitando ações preventivas e um menor prejuízo a vida humana e ao meio ambiente. Desenvolvimento da pesquisa. 0 produto químico nitrato de amônia tem grande relevância para a indústria, agricultura em geral, eis que é base química para a produção de diversos produtos químicos, sejam compostos fertilizantes, produtos farmacêuticos, produtos de higiene e limpeza industrial e comercial.

O nitrato de amônia é químico oxidante classificado pela ONU (Classe 5.1), porém podemos ter vários tipos de classificação deste composto dependendo da concentração de nitrato amônia ou a inserção de outras substâncias químicas, tais como, sulfato de amônia, compostos orgânicos e outros. Todos estes compostos são largamente utilizados por indústrias de bases de fertilizantes, explosivos entre outros. A empresa Pró Química foi uma das primeiras empresas a orientar quais os riscos potências e as ações de emergência que os produtos químicos podem causar ao meio ambiente seja natural ou artificial, tais como propagação de fogo, derramando ou vazamento deste e os primeiros socorros básicos em caso de acidentes envolvendo pessoas e animais. (Manual para atendimento de emergências com produtos perigosos/1994 - Pró Química - Abiquim).

Assim sendo, este produto requer uma série de normas e fiscalização para o armazenamento e transporte, sendo necessário controlar a quantidade estocada, tempo de armazenamento, ambiente ventilado, umidade relativa do ar e que permaneça longe 
de fontes de calor e combustíveis, o piso do local de armazenagem deve ser limpo e seco, o transporte do produto deve ser feito por veículos específicos credenciados e os responsáveis pelo armazenamento devem constituir brigada de incêndio. Citando como exemplo os sistemas elétricos sejam de iluminação, tomadas e outros tem que ser a prova de explosão obedecendo a NBR específica.

Para o transporte e armazenamento de produtos perigosos são determinadas às classes de risco e os rótulos de risco.

A classificação adotada para os produtos considerados perigosos é feita com base no tipo de risco que apresentam e conforme as Recomendações para o Transporte de Produtos Perigosos das Nações Unidas, compõe-se das seguintes classes, definidas nos itens $1.1 \mathrm{a}$ 1.9: Classe 1 - Explosivos; Classe 2 - Gases, com as seguintes subclasses: Subclasse 2.1 Gases inflamáveis; Subclasse 2.2 - Gases não-inflamáveis, não-tóxicos; Subclasse 2.3 Gases tóxicos. Classe 3 - Líquidos Inflamáveis; Classe 4 - Esta classe se subdivide em: Subclasse 4.1 - Sólidos inflamáveis; Subclasse 4.2 - Substâncias sujeitas a combustão espontânea; Subclasse 4.3 - Substâncias que, em contato com a água, emitem gases inflamáveis. Classe 5 - Esta classe se subdivide em: Subclasse 5.1 - Substâncias oxidantes; Subclasse 5.2 - Peróxidos orgânicos. Classe 6 - Esta classe se subdivide em: Subclasse 6.1 - Substâncias tóxicas (venenosas); Subclasse 6.2 - Substâncias infectantes. Classe 7 - Materiais Radioativos; Classe 8 - Corrosivos e Classe 9 - Substâncias Perigosas Diversas. Os produtos das Classes 3, 4, 5 e 8 e da Subclasse 6.1 classificam-se, para fins de embalagem, segundo três grupos, conforme o nível de risco que apresentam: Grupo de Embalagem I - alto risco; Grupo de Embalagem II - risco médio e Grupo de Embalagem III - baixo risco.

Ao ser alocado a determinada Classe de Risco o produto perigoso também recebe um número ONU, que o identifica internacionalmente. No caso da amônia - № ONU 1005. 0 transporte de produtos perigosos deve atender diversas exigências, sendo elas, documentação: declaração de carga emitida pelo expedidor contendo a descrição correta do produto perigoso transportado.

Exemplo: Amônia - № ONU 1005, instruções escritas para o caso de qualquer acidente indicando procedimentos a serem adotados, documento comprobatório de realização de Curso de Movimentação de Produtos Perigosos para o motorista, certificado de capacitação dos veículos e dos equipamentos de transporte de produtos perigosos a granel, documento de inspeção técnica veicular e demais declarações, autorizações e licenças previstas.

Embalagens e Volumes: produtos perigosos devem ser acondicionados em embalagens e volumes de boa qualidade e resistentes para suportar os choques e as operações do transporte. Ensaios de acordo com programa de avaliação da conformidade conforme regulamentação de cada Estado Parte, marcação: exibição do nome apropriado para embarque e do número ONU correspondente, precedido das letras "UN" ou "ONU" em cada volume, indicação de que a embalagem corresponde a um projeto-tipo aprovado pela autoridade competente, rotulagem : Os Rótulos de Risco devem ser colocados próximos à marcação do nome apropriado para embarque, sem serem cobertos por qualquer parte da embalagem ou qualquer outro rótulo ou marcação, sinalização das Unidades de Transporte: A sinalização das unidades de transporte é feita, basicamente, por meio da utilização de rótulos de risco e painéis de segurança. Rótulos de Risco: afixados na unidade de transporte para indicar o risco apresentado pelo produto perigoso transportado. 
Painéis de Segurança: devem ser afixados na unidade de transporte para indicar o número de risco e o número ONU do produto perigoso transportado.

0 transporte de resíduos perigosos deve atender às exigências prescritas para a classe ou subclasse apropriada, considerando os respectivos riscos e os critérios de classificação constantes destas Instruções. Os resíduos que não se enquadram nos critérios aqui estabelecidos, mas que apresentam algum tipo de risco abrangido pela Convenção da Basiléia sobre o Controle da Movimentação Transfronteiriça de Resíduos Perigosos e sua Disposição (1989), devem ser transportados como pertencentes à Classe 9.

Exceto se houver uma indicação explícita ou implícita em contrário, os produtos perigosos com ponto de fusão igual ou inferior a $20^{\circ} \mathrm{C}$, à pressão de $101,3 \mathrm{kPa}$, devem ser considerados líquidos. Uma substância viscosa, de qualquer classe ou subclasse, deve ser submetida ao ensaio da Norma ASMT D 4359-1984, ou ao ensaio para determinação da fluidez prescrito no Apêndice A-3, da publicação das Nações Unidas ECE/TRANS/80 (Vol. 1) (ADR), com as seguintes modificações: o penetrômetro ali especificado deve ser substituído por um que atenda à Norma da Organização Internacional de Normalização ISO 2137-1985 e os ensaios devem ser usados para substâncias de qualquer classe

0 produto é considerado de risco eis que é base para vários tipos de explosivos, sendo controlado o armazenamento e o transporte e utilização pelo Exército Brasileiro, existindo um departamento responsável por este produto, diretoria de fiscalização de produtos controlados (DFPC). Atualmente existe uma atualização das normas especificas de segurança, Portaria Colog $n^{\circ} 147$, inclusive contou com a participação de um grupo técnico de trabalho da ANDA. 0 Brasil é um grande consumidor de nitrato de amônia e grande parte deste consumo é utilizado na produção de explosivos. Importando cerca de 1,4 milhão/ano, sendo a Rússia o principal exportador para Brasil. (Segundo a Associação Nacional para Difusão de Adubos -ANDA).

Os documentos necessários para o transporte de nitrato de amônia são: certificado de Capacitação para Transporte de Produtos Perigosos à Granel (caminhões, cavalo mecânico, caminhão-trator) e equipamento (carreta basculante e carreta graneleira), emitido por agente de inspeção credenciado pelo INMETRO, observando o prazo de validade de 01 (um) ano, sendo este certificado não obrigatório para os produtos embalados; Certificado de Registro da Transportadora no Ministério da Defesa - Exército Brasileiro, relativo a fiscalização de Produtos Controlados; guia de Tráfego emitida pelo expedidor do produto e devidamente autorizada pelo Ministério da Defesa Exército Brasileiro; ficha de Emergência e seu respectivo envelope para transporte conforme NBR 7503 Ficha de emergência e envelope para o transporte terrestre de produtos perigosos características, dimensões e preenchimento.

De acordo com o Jornal e Editora A Tribuna de Santos, ainda nos dias de hoje temos problemas com o transporte de nitrato de amônia, como divulgação após operação do Ibama - Instituto Brasileiro do Meio Ambiente e dos Recursos Naturais Renováveis, PRE e ANTT - Agência Nacional de Transporte Terrestre, onde caminhões foram autuados por descomprirem exigências no transporte deste produto. Os veículos foram abordados ao saírem do Porto de Santos, onde carregaram o produto que teriam destino a fábricas de fertilizantes de Cubatão/SP. 
Segundo a chefe local do Ibama, Ana Angélica Alabarce, estão sendo inspecionadas todos os aspectos da operação de cargas perigosas, como o nitrato de amônia, no Porto e no Polo de Cubatão/SP (figuras 1 e 2). Essa inspeção foi motivada após o acidente ocorrido na zona portuária de Beirute em 04 de agosto de 2020. A movimentação de nitrato de amônia ocorre no Terminal Marítimo Termag (figura 3), localizado na Margem Esquerda Guarujá, já na Margem Direita Santos, atualmente não há armazenamento deste produto, pois quando existe operação de nitrato de amônia ela é feita com descarga direta para caminhões, que deixam a zona portuária imediatamente. Somente o ano passado foram desembarcados cerca de 2,2 milhões de toneladas de fertilizantes no Porto de Santos de acordo com o Grupo A Tribuna.

\section{RESULTADOS E DISCUSSÃO}

A segurança no transporte de cargas especiais é um tema cada vez mais debatido por especialistas no setor de logística, porém o setor político segue com um quadro sem muitas expectativas a curto prazo de maiores investimentos, portanto compete às empresas e gestores investigarem e desenvolverem meios de garantir a segurança de suas cargas, bem como a integridade física de seus funcionários, terceiros e ao meio ambiente, por consequência a facilitação no andamento das operações e qualidade nos serviços. 0 investimento em tecnologia cada vez mais avançadas é imprescindível para se desenvolver um trabalho eficaz e acima de tudo quando se trata de segurança. 0 uso de softwares e equipamentos de última geração, gestores e pessoal capacitado são requisitos básicos para as empresas que se preocupam com a segurança dos seus colaboradores, além de serem essenciais para acompanhamento na localização do transporte com informações em tempo real e fundamental para evitar atrasos e roubos.

0 crucial quando se trata de segurança é a eficiente manutenção periódica realizada em modais, equipamentos e acessórios que estiverem ligados ao transporte, armazenamento e manuseio, evitando liberação de gases tóxicos, explosões e situações de risco em geral.

A pesquisa nos permite concluir que a gestão de segurança no transporte de carga perigosa como o nitrato de amônia deve seguir um bom planejamento de operações, nas melhores condições estratégicas e estruturais, aprimoramentos constantes e com maiores responsabilidades das empresas no cumprimento das normas, bem como o constante investimento público em inspeções e fiscalizações e em obras e melhorias de estradas e ferrovias, contribuindo não somente com o aumento da segurança do transporte do nitrato de amônia pelo país, assim como com a segurança de todos nos diversos modais de transporte de cargas.

Os contratempos nas operações do dia a dia são inúmeros, então, os gestores dessa área necessitam estar por dentro das novidades para buscar metodologias que fomentem um crescimento sustentável da atividade, tendo sempre em mente a inovação e o aproveitamento máximos dos recursos e evitando acidentes causando danos a saúde do homem e do meio ambiente.

\section{CONSIDERAÇÕES FINAIS}

Através do presente estudo pode-se concluir da importância do transporte em segurança de materiais e cargas especiais como é o caso do nitrato de amônia, pois os mesmos podem expor ao risco aos que estão ligados direta ou indiretamente à operação. 
Percebe-se também a importância de um maior número de inspeções e fiscalizações por parte dos órgãos responsáveis a todos os envolvidos na cadeia de passagem de tal tipo especial de carga, uma vez que a pesquisa evidenciou que a falta de uma ação fiscal permanente leva a empresas e colaboradores burlarem normas e leis vigentes para o setor, que se perfaz num número baixo de autuações e multas. Para que o transporte seguro aconteça percebe-se da importância de uma eficiente política de cobrança dos órgãos responsáveis no cumprimento e comprometimento integral e prudente para esse tipo de transporte juntamente as empresas, bem como reciclagem a todos os envolvidos ocasionalmente. A desinformação e o baixo número de fiscalização são fatores determinantes de perigo.

0 transporte de nitrato de amônia, como quaisquer outras cargas perigosas, que demandam transporte especial, possui legislações, documentos, e cuidados específicos, o que reforça a urgência de que além de competência e documentação necessária os órgãos responsáveis estejam mais presente nas ações desses transportes, assim como notou-se a necessidade de um estudo onde possa se verificar as falhas e descumprimentos na logística de transporte do nitrato de amônia do Porto de Santos/SP até o destino nas fábricas de fertilizantes em Cubatão/SP. 0 perigo na região é eminente e todo tipo de estudo e investimento em segurança nesse tipo de transporte se faz necessário, portanto, por ser de muita relevância e urgência esperamos que estimule o interesse de pesquisadores de estudos similares a esse tipo de transporte de carga, e para que a contribuição nesse segmento de prevenção de acidentes seja efetiva na busca de uma melhor identificação dos perigos e riscos.

\section{REFERÊNCIAS}

[1]. BALLOU, R.H. Gerenciamento da cadeia de suprimentos/logística empresarial. 5a ed. Porto Alegre/SC: Bookman, 2006.

[2]. CLRB - CONSELHO DE LOGÍSTICA REVERSA NO BRASIL. Logística Reversa. Disponível em: https://www.clrb.com.br/site/clrb.asp. Acesso em: 18 ago. 2017.

[3]. CERVO, A. L. BERVIAN, P. A. Metodologia científica. 5.ed. São Paulo: Prentice Hall, 2002.

[4]. GIL, A. C. Métodos e técnicas de pesquisa social. 5.ed. São Paulo: Atlas, 1999. 


\section{Capítulo 8}

\section{Sistema agroindustrial citrícola: Exportação do suco de laranja}

\section{André Martins dos Santos}

\section{Giovanni Tirelli Martins Rodrigues}

Resumo: Para atender padrões do mercado internacional o suco de laranja a ser exportado requer práticas e equipamentos especiais que conservem características e qualidade, e para isso, a costa brasileira tem portos marítimos preparados, cujas empresas têm forte apoio logístico, mas, no entanto, existem previsões pessimistas para as exportações do produto. Estimativas de que a safra 2020/2021 de laranja registraria uma quebra "histórica" em função dos problemas climáticos. Esta pesquisa bibliográfica busca compreender as dificuldades que esta cadeia produtiva enfrenta. Um estudo que demonstra a evolução da exportação do suco de laranja e as estimativas da safra 2021/2022 da laranja brasileira nas principais regiões produtoras do país.

Palavras-chave: Exportação. Laranja. Produção 


\section{INTRODUÇÃO}

Quando se trata de produzir e exportar suco de laranja, o Brasil vem sendo peça-chave no comércio internacional, com diversos países consumindo o suco de laranja brasileira. Porém, segundo dados divulgados pela Secretaria de Comércio Exterior (SECEX), a exportação brasileira de suco de laranja registrou queda de $23,5 \%$ no primeiro semestre da safra 2020/2021, quando comparada com a safra anterior. Há ainda o fator clima, as intempéries, que mesmo sendo previsíveis pela meteorologia não podem ser controladas. A estimativa do Fundo de Defesa da Citricultura (FUNDECITRUS) foi de que a safra 2020/2021 de laranja registraria uma quebra "histórica" em função dos problemas climáticos.

É para entender qual a verdadeira dimensão dos desafios desta cadeia produtiva que se faz necessária esta pesquisa científica, que estuda algumas das mais relevantes questões do sistema agroindustrial citrícola, com o objetivo de demonstrar a evolução da exportação do suco de laranja durante a última década e as estimativas da safra 2021/2022 da laranja brasileira nas principais regiões produtoras do país. Assim como definida por Rampazzo (2002), esta pesquisa [...] "procura um problema a partir de referências teóricas publicadas", e que, conforme Prodanov (2013) foi realizada por meio de sites, livros e artigos acadêmicos anteriormente publicados.

\section{EMBASAMENTO TEÓRICO}

A cadeia produtiva do suco de laranja consiste em plantio, colheita e indústria onde é produzido, ou seja, passa por diversos processos até estar pronto para exportação (PATTO, et al., 2019). A diferença entre suco, néctar e refresco é relacionada ao teor do suco de fruta presente na bebida envasada. Sucos devem conter $100 \%$ de fruta in natura, sem conservantes ou adoçantes e sem corantes artificiais, com a possibilidade ou não de conter a polpa da própria fruta (NEVES, 2010). De acordo com o Departamento de Pesquisas e Estudos Econômicos do Bradesco (DEPEC, 2016), o início da produção do suco de laranja ocorre a partir de três anos após o plantio e uma árvore pode durar até vinte anos, já o suco concentrado congelado pode durar até três anos sem perder suas características. O plantio de laranjas pode ser desde aquele feito por pequenos agricultores independentes, que plantam e vendem para comerciantes de frutas, ou para cooperativas; até o feito por médios e grandes agricultores, que fornecem grandes quantidades, sem entremeios, às indústrias de processamento. São geralmente vendidas a granel, mas utiliza-se a caixa equivalente a 40,8 kg de laranjas (ou 90 pounds) como sistema de peso e medida, já os preços do suco de laranja são balizados no mercado internacional, na Bolsa de Nova Iorque - NYBOT, sendo a unidade de medida a libra peso (453,6 gramas) (ANJOS, et al., 2017).

O Brasil tem concentrada sua produção no interior de São Paulo e no triangulo mineiro, região conhecida como cinturão citrícola. De acordo com Neves et al. (2010), 53\% da produção mundial concentram-se no estado de São Paulo e, três a cada cinco copos de suco de laranja consumidos em todo o mundo são de origem brasileira. 0 estado de São Paulo lidera todo este ciclo logístico e, segundo Barat (2007), a cidade de Matão, corresponde a mais da metade da produção de todo o estado. Segundo Perez (2014), apud PATTO, et al., (2019), a laranja brasileira é considerada a melhor do mundo e, 80\% do suco concentrado exportado em todo o mundo têm origem no Brasil.

Neves (2010) constata que a Europa é o principal destino das exportações do suco de laranja brasileiro. Desde a década de 80, o país detém o título de maior produtor de 
laranja e também do suco. Segundo o Departamento de Pesquisas e Estudos Econômicos do Bradesco (DEPEC, 2017), a exportação do suco de laranja representa 0,5\% das exportações totais do Brasil, e ainda o DEPEC apud Celestino e Santos (2017), explica que "o Brasil possui grandes vantagens competitivas que são: baixo valor de mão-deobra, fruta de qualidade, baixo custo de produção e apoio logístico com terminais privativos". Esta cadeia arrecada US\$ 189 milhões em impostos para o Estado brasileiro (NEVES, 2010). Todos estes aspectos fazem com que o país continue sendo o maior exportador e produtor. A produção da laranja, assim como o seu destino, mudou ao longo do tempo, ficando evidente um aumento do fornecimento para a indústria e redução do fornecimento ao consumo in natura (PATTO, et al., 2019). No entanto, Neves (2010) observa que o suco de laranja vem perdendo terreno para outros sucos e bebidas, lançadas cada vez com uma maior frequência e que vêm ganhando mais espaço no mercado.

De acordo com Silva (2000), devido ao estado de São Paulo ser líder na produção de laranja, a exportação do suco é mais viável quando levada até Santos (SP). Com base em dados obtidos no site Mapeia (2021), o percurso entre a matriz da Citrosuco, em Matão (SP) até Santos (SP) é de $396 \mathrm{KM}$, totalizando 5 horas e 5 minutos. 0 porto de Santos lidera as exportações do produto, além disso, a maior exportadora mundial possui instalações na cidade. A empresa Citrosuco atingiu tal posição após fusão com a Citrovita, do Grupo Votorantim (MAGNABOSCO, 2010). De acordo com o site Portos e Navios (2015), para atender a demanda, o cais santista conta com três terminais dedicados à movimentação dessa mercadoria. Dois deles estão na margem direita do canal do porto, em áreas arrendadas da União: o da Citrosuco e o da Louis Dreyfus Commodities (LDC). 0 terceiro, da Cutrale, é de uso privativo e fica na margem esquerda do canal de navegação. $\mathrm{O}$ armazenamento nos ambientes refrigerados na zona portuária de Santos é reconhecido em virtude dos equipamentos modernos (principalmente os tanques herméticos e assépticos), e também da transferência de grandes volumes dos tanques para os navios (PEREIRA, et al., 2019). Nos terminais fora do Brasil, o suco é armazenado e distribuído aos clientes por empresas que envasam e levam o produto até o varejo (ANJOS, et al., 2017). Os Estados Unidos, União Européia, Japão e Austrália, possuem terminais portuários administrados pelas empresas do Brasil, para receberem o suco. Vieira (2020) alerta que, ainda que um aumento da exportação seja ótimo, a rentabilidade não necessariamente representa um ganho para as processadoras e produtores rurais, mesmo com o dólar perto de $\mathrm{R} \$ 6$. Isso porque o preço mundial vem caindo ao longo dos anos, também em parte pela grande produção. Na China, a tonelada do produto brasileiro custou, em 2020, US\$1.400 (cerca de R \$ 7.700).

Segundo Anjos et al., 2017, o Brasil é líder de exportação, porém há diversos empecilhos no que diz respeito ao transporte terrestre do país. Para Rojas (2014), o transporte rodoviário é o principal meio para movimentar cargas, entretanto os problemas em relação à infraestrutura contribuem para o aumento dos custos. Já que a produção de laranja se concentra no interior do estado de São Paulo, isso traz problemas logísticos, como o alto custo no transporte terrestre, já que para Prando e Prado (apud Anjos et al., 2017), o modal sofre com falta de recursos e revitalizações das estradas, por exemplo. No Brasil, cerca de $20 \%$ do fornecimento de frutas para os grandes produtores de suco vem de suas próprias plantações, o restante é obtido por meio de contratos de longo prazo com produtores de médio e grande porte. Custos de colheita e transporte ficam por conta do produtor, que enfrenta dificuldades sendo produtor/exportador, por 
exemplo, com o câmbio, que afeta a sua rentabilidade, o deixando sem capital para investir e reinvestir em sua fazenda (DEPEC, 2016).

\section{DESENVOLVIMENTO DA TEMÁTICA}

Para compreender o desafio da cadeia do suco de laranja exportado pelo Brasil, a seguir são apresentadas algumas peculiaridades de cada uma de suas etapas:

\subsection{PLANTIO DAS MUDAS}

O ideal, depois da área de plantio já escolhida, é preparar a terra no verão, antes do plantio do pomar, retirando restos de vegetação, pedras, fazer uma subsolagem, e aplicando calcário, conforme uma análise do solo. Conforme a empresa Citrosuco, a produção de mudas inicia-se com o ciclo da cultura, no Banco de Germoplasma de Sementes originárias de plantas selecionadas, a fim de assegurar o melhor material genético em relação à produtividade e a qualidade do suco. 0 processo começa com a produção de mudas, preparadas com 30 dias de antecedência, e em geral, vendidas com 1 metro de altura e um ano de idade (ANJOS, et al., 2017). É feito um controle rígido de pragas e doenças, visando de forma racional, o uso de defensivos agrícolas (FONSECA; SANTOS, 2019). O controle fitossanitário é foco de investimentos constantes, com iniciativas como o manejo integrado e o uso dos defensivos. São utilizados defensivos agrícolas registrados junto aos órgãos responsáveis, respeitando as exigências brasileiras e dos países para os quais as empresas exportam (Lista PIC). Segundo a FUNDECITRUS, a lista de Produção Integrada de Citros (Lista PIC), é feita em consulta a um comitê, formado por institutos de pesquisa, consultores e indústrias produtoras de suco, e coloca à disposição do produtor uma grade de ingredientes ativos de inseticidas, acaricidas, fungicidas e herbicidas autorizados para uso.

\subsection{A COLHEITA DAS LARANJAS}

A colheita é realizada em diferentes períodos conforme a maturação dos frutos. 0 gráfico 1 mostra a diversificação das variedades nos pomares citrícolas brasileiros ao longo de um ano.

Em sua maioria, a colheita é feita de forma manual no Brasil. Usam-se sistemas de transbordo (trator guincho) no carregamento de bags (grandes sacolas com capacidade para até $700 \mathrm{~kg}$ de laranja) para que não seja necessária a passagem de caminhões no pomar. Os veículos utilizados na colheita circulam apenas dentro da fazenda, para evitar que infestações sejam trazidas da rua (ANJOS, et al., 2017). As laranjas colhidas seguem para packing houses, geralmente localizados dentro das próprias fazendas; são selecionadas manualmente; é retirada uma amostra para avaliação de qualidade; são classificadas por tamanho e as laranjas descartadas vão para a produção de ração animal. Para os processadores, é fundamental ter fornecimento ininterrupto de laranjas, e sendo uma commodity perecível, o produtor não tem como estocar para esperar uma possível melhora de preços, e desta maneira, a venda para a indústria é feita de modo imediato. É importante a diversificação das variedades nos pomares citrícolas, por estratificar a colheita de laranja ao longo do ano, evitando assim uma concentração da oferta em alguns poucos meses (NEVES, 2010). 
Gráfico 1: Período de colheita por variedade e percentual da produção

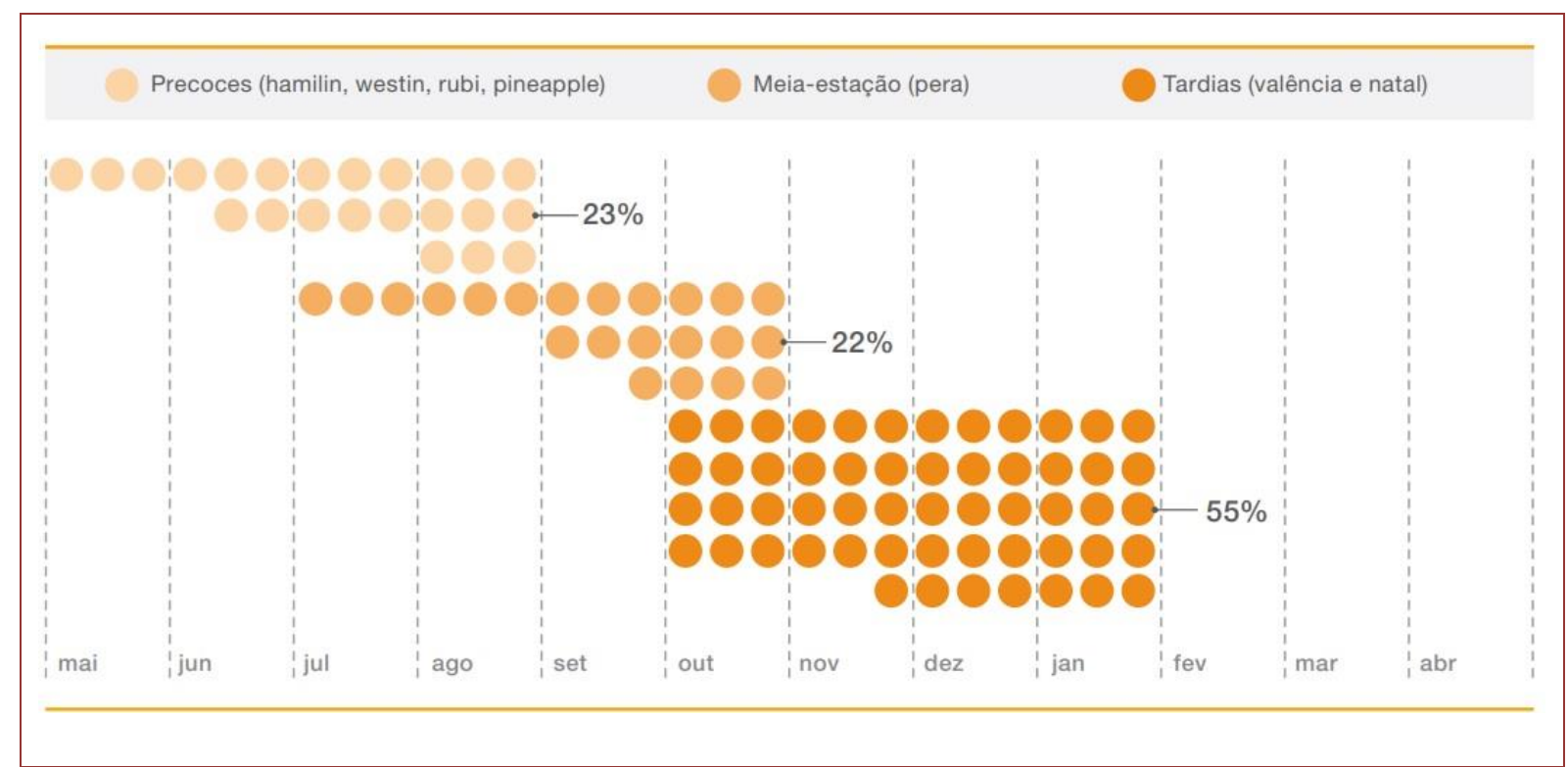

Fonte: Neves; Markestrat; CitrusBR (2010).

\subsection{INDUSTRIALIZAÇÃO E ARMAZENAGEM DO SUCO DE LARANJA}

Na indústria as laranjas são separadas por máquinas extratoras do suco, do óleo da casca e do bagaço da fruta. 0 suco vai para os filtros e centrífugas, onde os gomos de polpas, sementes e excesso de polpa são removidos. 0 bagaço, as cascas e as sementes são destinadas à fabricação de ingredientes específicos. É nesta etapa que são feitos os sucos não concentrados (suco integral) e o suco concentrado e congelado (FONSECA; SANTOS, 2019). Na indústria do suco processado, ele pode ser exportado e consumido de duas formas:

- Suco concentrado congelado, os FCOJ (Frozen Concentrate Orange Juice, no qual a água é retirada do suco natural;

- Suco não concentrado, os NFC (Not-from-concentrate), que são os sucos pasteurizados sem a retirada da água. Para cada tipo de suco processado a armazenagem é feita de uma forma, os concentrados (FOCJ) são resfriados com temperaturas negativas e armazenados em tanques de inox que ficam localizados dentro de câmaras frias, já os não concentrados (NFC) são guardados em tanques de inox com armazenamento antisséptico.

É essencial uma armazenagem adequada já que se trata de um produto perecível, para evitar a contaminação se faz necessário tanques para transporte a granel ou contêineres isotérmicos e refrigerados para transporte unitizado (OLIVEIRA, et al., 2009). Para o armazenamento do suco tipo NFC a temperatura é o principal fator para conservação então requer cuidados especiais. A qualidade do suco é acompanhada frequentemente por meio de amostras, testes em laboratórios e métodos especiais. Para o suco tipo FCOJ, o armazenamento é o mesmo, porém, conservado em temperaturas negativas (FONSECA; SANTOS, 2019). 


\subsection{TRANSPORTE}

Empresas do setor desenvolveram seus processos logísticos de exportação no qual caminhões tanques transportam suco congelado e refrigerado das fábricas aos portos, onde permanecem até serem bombeados para os navios. Segundo Oliveira (2009), carretas são especialmente projetadas para esta finalidade, possuindo controles para evitar a contaminação do produto e manter sua qualidade além de proporcionar uma maior conservação das características do produto. Os caminhões-tanques têm como propósito manter a temperatura do suco de laranja de -8 a -10 graus Celsius, com adaptações que permitem o descarregamento rápido e seguro, não contendo praticamente nenhum tipo de contato manual e realizando toda operação de forma hermética, como observado na empresa Cutrale, no porto de Santos, onde caminhõestanque com capacidade para até 48 mil litros (divididos em dois tanques por caminhão) chegam ao terminal e o suco é então transferido dos tanques do caminhão ao tanque frigorífico do terminal em processo que dura em média uma hora e meia (FONSECA; SANTOS, 2019).

A movimentação do produto da área de estocagem até os navios Tank-Farm (navios tanque) é feita por tubos interligados entre os terminais e o cais. São utilizados sucodutos (dutos recebem o nome do produto que transportam) especiais com isolamento térmico, para o bombeamento direto do suco congelado, do terminal do porto aos navios tanques. Esse sucoduto possui controle de fluxo e pressão, além de válvulas automáticas que impedem qualquer tipo de contaminação por agentes externos (ANJOS, et al., 2017).

Uma opção é exportar o suco de laranja em tambores da fábrica ao porto em caminhões frigoríficos e depois estes tambores são transferidos a navios reefers (frigoríficos) que levarão ao porto de destino e depois descartarão estes tambores, já que não compensa retorná-los vazios após o uso. (OLIVEIRA, et al., 2009 apud. FONSECA; SANTOS, 2019). A China, Coréia do Sul e Emirados Árabes, recebem o suco em tambores (LOHBAUER, 2009).

Para considerar o tipo de carga que está sendo transportada, é necessário analisar em qual local ela está armazenada. Caso o armazenamento do suco de laranja seja em tambores, é considerado como carga geral e caso seja movimentado em tanques, como granel líquido (PEREIRA, et al., 2019). 0 suco pode ser exportado em estado líquido (integral e concentrado) e congelado (integral), com isso, todo tipo de precaução durante o transporte marítimo é necessária, pois por se tratar de uma mercadoria não comum em relação ao seu estado (líquido e congelado), é importante manter a estabilidade da carga para preservação da qualidade do produto. 0 Brasil possui uma frota de navios de granel líquido para operações exclusivas de suco de laranja, sendo que cada navio, opera com carga referente a aproximadamente 600 caminhões. (MAMEDE, et al., 2018).

Navios utilizados no transporte do suco de laranja passam por rigorosos controles de limpeza e qualidade, não podendo ser lavados nem pintados de qualquer modo, como o navio "Orange Sun", construído em 2007, com capacidade para $29.200 \mathrm{~m}^{3}$ toneladas de suco, que tem seu compartimento de carga revestido de aço inoxidável e a capacidade de transportar 280 TEU'S (Twenty Equivalent Unit - unidade de 20 pés) frigorificados em seu convés (ANJOS, et al., 2017), já que o suco pode ser também transportado dentro de containers reeffer (até 18 mil litros / container). 


\section{RESULTADOS E DISCUSSÃO}

Figura 1: Sistema Agroindustrial Citrícola.

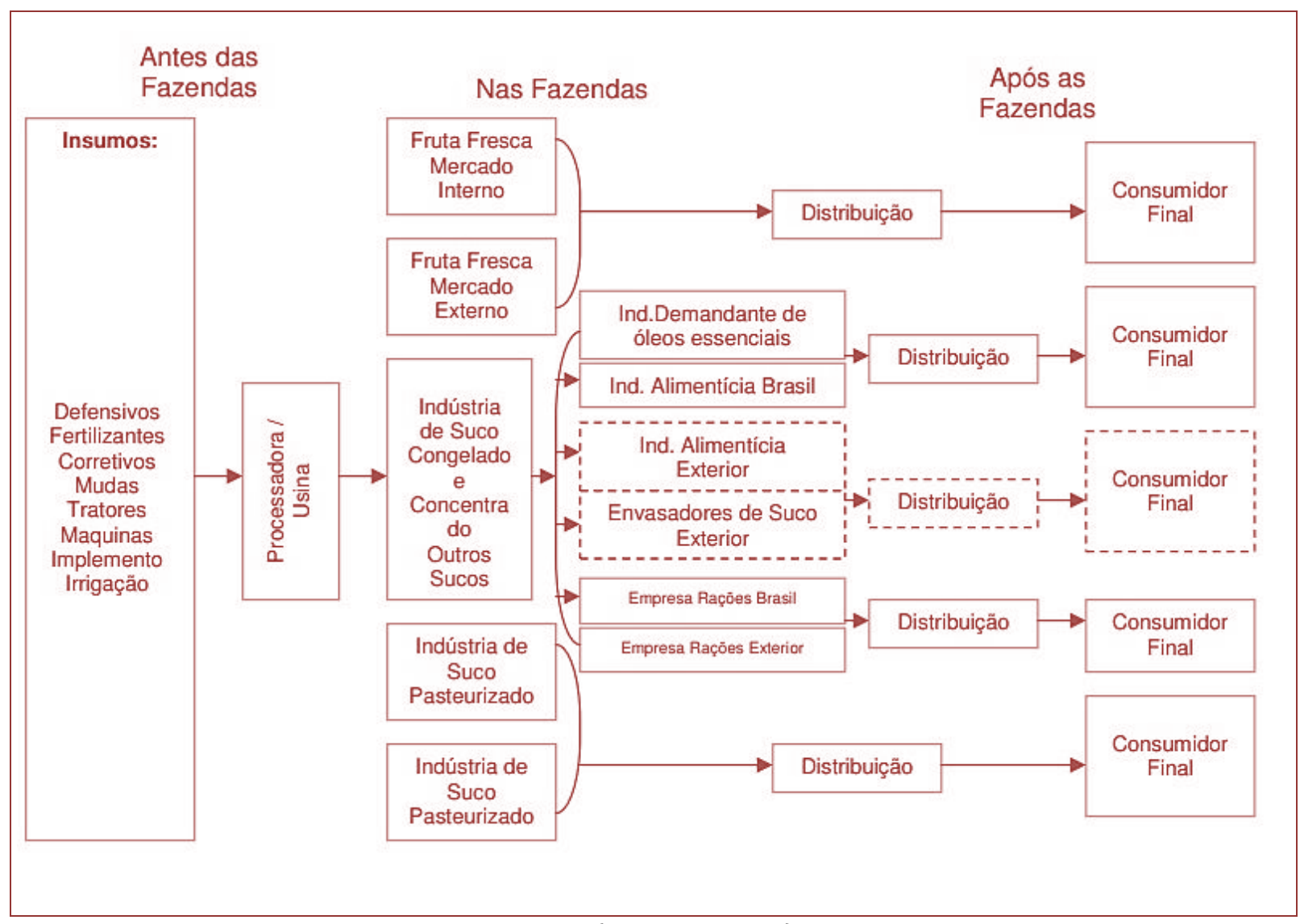

Fonte: (GUERISE, 2006).

A Figura 1 mostra a representação do Sistema Agroindustrial Citrícola e o gráfico abaixo mostra o comportamento das exportações do suco de laranja na última década.

Gráfico 2: Exportações volume FCOJ e NFC em toneladas.

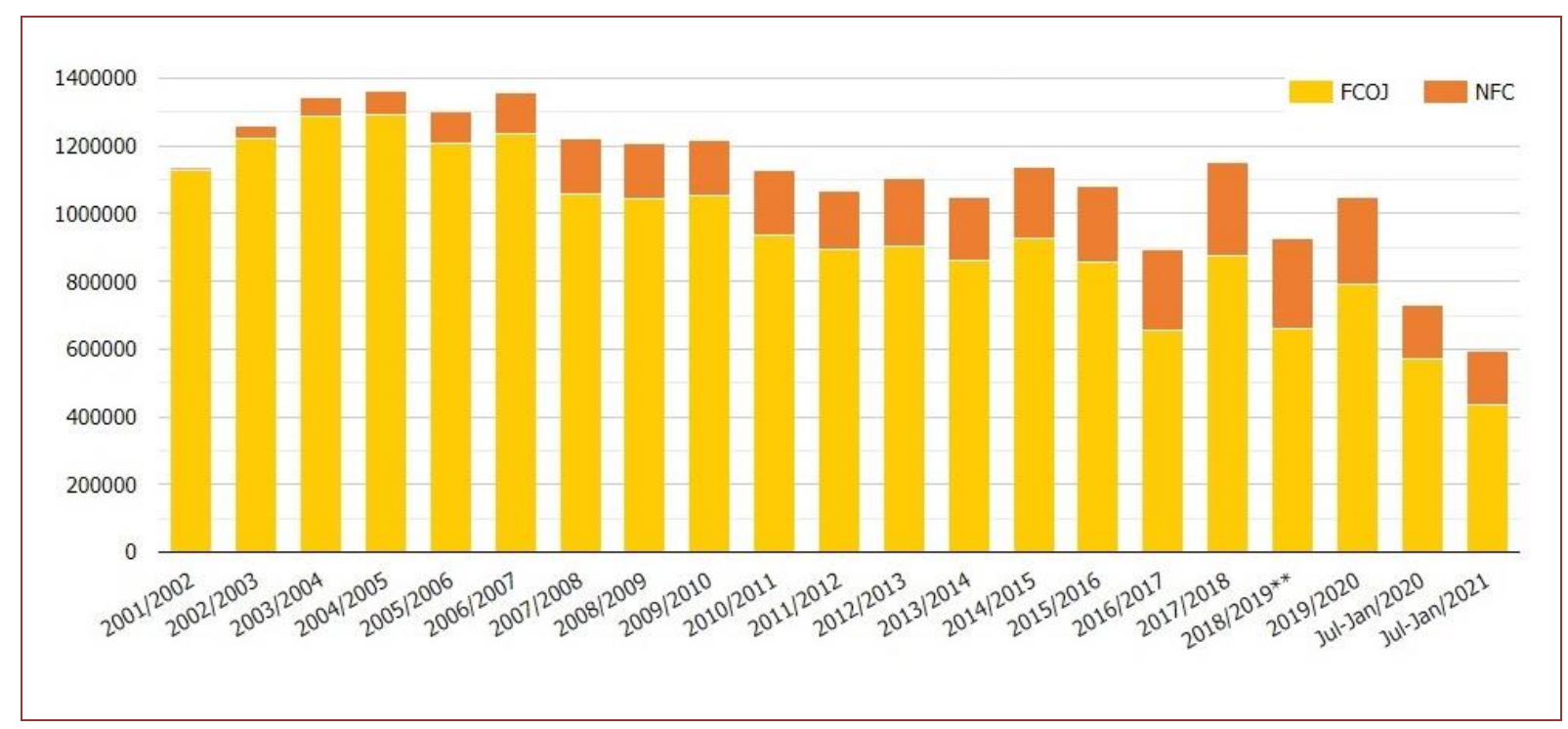


Fonte: FUNDECITRUS (2021).

Para realizar uma estimativa, o FUNDECITRUS, manteve um método objetivo utilizado nas últimas safras, baseado em dados quantitativos, medições em campo, contagem e pesagem de frutos, aplicados na equação abaixo:

$$
\text { Produção estimada }=\frac{\text { Árvores produtivas } \times \text { Frutos por árvore } \times(1-\text { Taxa de queda } \%) \times(1-\mathrm{FC} \%)}{\text { Frutos por caixa }}
$$

A produtividade média de laranjas estimada pelo Fundo de Defesa da Citricultura é de 850 caixas por hectare e 1,77 caixas por árvore, ante 737 caixas por hectare e 1,55 caixas por árvore colhidas na safra 2020/21. Para a safra 2021/2022, é estimada uma produção de 294,1 milhões de caixas de 40,8 quilos no cinturão citrícola de São Paulo e Triângulo e Sudoeste de Minas Gerais. 0 valor corresponde a um aumento de 9,51\% com relação à última safra, mas ainda fica abaixo da média das últimas dez safras em, aproximadamente, 35 milhões de caixas, o que equivale a uma queda de 10,53\%. As tabelas a seguir apresentam estimativas da safra de laranja 2021/22, as produtividades por setor e as variações em relação à temporada anterior.

Tabela 1: Estimativa da safra de laranja 2021/22 por setor

\begin{tabular}{|c|c|c|c|c|c|c|c|}
\hline \multirow{2}{*}{ Setor } & \multirow{2}{*}{$\begin{array}{l}\text { Área de } \\
\text { pomares } \\
\text { adultos }\end{array}$} & \multirow{2}{*}{$\begin{array}{l}\text { Densidade } \\
\text { média }^{1} \text { dos } \\
\text { pomares } \\
\text { adultos }\end{array}$} & \multirow{2}{*}{$\begin{array}{c}\text { Árvores } \\
\text { produtivas }\end{array}$} & \multirow{2}{*}{$\begin{array}{c}\text { Frutos por } \\
\text { árvore na } \\
\text { derriça }^{2}\end{array}$} & \multicolumn{3}{|c|}{$\begin{array}{l}\text { Estimativa da safra de laranja } \\
2021 / 22\end{array}$} \\
\hline & & & & & Por árvore & Por hectare & Total \\
\hline & (hectares) & $\begin{array}{l}\text { (árvores/ } \\
\text { hectare) }\end{array}$ & $\begin{array}{l}(1.000 \\
\text { árvores })\end{array}$ & (número) & $\begin{array}{l}\text { (caixas/ } \\
\text { árvore) }\end{array}$ & $\begin{array}{l}\text { (caixas/ } \\
\text { hectare) }\end{array}$ & $\begin{array}{l}(1.000 .000 \\
\text { caixas })\end{array}$ \\
\hline Norte........................ & 83.983 & 478 & 39.665 & 688 & 1,90 & 899 & 75,46 \\
\hline Noroeste................. & 34.003 & 477 & 15.971 & 559 & 1,54 & 725 & 24,65 \\
\hline 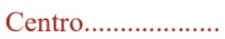 & 97.099 & 487 & 46.479 & 617 & 1,70 & 816 & 79,20 \\
\hline Sul............................ & 65.597 & 493 & 31.254 & 595 & 1,64 & 781 & 51,22 \\
\hline Sudoeste................. & 65.441 & 518 & 33.191 & 694 & 1,92 & 972 & 63,64 \\
\hline Total....................... & 346.123 & 491 & 166.560 & 639 & 1,77 & 850 & 294,17 \\
\hline
\end{tabular}

Fonte: (FUNDECITRUS, 2021).

Tabela 2: Produtividade por hectare dos setores nas safras 2016 a 2021

\begin{tabular}{|c|c|c|c|c|c|c|}
\hline Setor & $2016 / 17$ & $2017 / 18$ & $2018 / 19$ & $2019 / 20$ & $2020 / 21$ & $2021 / 22^{e}$ \\
\hline & $\begin{array}{l}\text { (caixas/ } \\
\text { hectare) }\end{array}$ & $\begin{array}{l}\text { (caixas/ } \\
\text { hectare) }\end{array}$ & $\begin{array}{l}\text { (caixas/ } \\
\text { hectare) }\end{array}$ & $\begin{array}{l}\text { (caixas/ } \\
\text { hectare) }\end{array}$ & $\begin{array}{l}\text { (caixas/ } \\
\text { hectare) }\end{array}$ & $\begin{array}{l}\text { (caixas/ } \\
\text { hectare) }\end{array}$ \\
\hline Norte & 495 & 1.108 & 606 & 1.070 & 648 & 899 \\
\hline Noroeste......................... & 376 & 882 & 404 & 924 & 468 & 725 \\
\hline 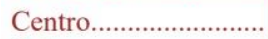 & 616 & 984 & 707 & 1.032 & 667 & 816 \\
\hline 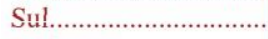 & 664 & 989 & 770 & 936 & 725 & 781 \\
\hline 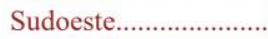 & 950 & 1.154 & 1.195 & 1.217 & 1.106 & 972 \\
\hline 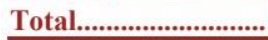 & 634 & 1.033 & 756 & 1.045 & 737 & 850 \\
\hline
\end{tabular}

Fonte: (FUNDECITRUS, 2021). 
Tabela 3: Variação da produtividade por hectare dos setores em relação à temporada anterior

\begin{tabular}{|c|c|c|c|c|c|c|c|c|c|c|}
\hline \multirow[t]{2}{*}{ Setor } & \multicolumn{2}{|c|}{$\begin{array}{c}2017 / 18 \\
\text { em comparação à } \\
2016 / 17\end{array}$} & \multicolumn{2}{|c|}{$\begin{array}{c}2018 / 19 \text { em } \\
\text { comparação à } \\
2017 / 18\end{array}$} & \multicolumn{2}{|c|}{$\begin{array}{c}2019 / 20 \\
\text { em comparação à } \\
2018 / 19 \\
\end{array}$} & \multicolumn{2}{|c|}{$\begin{array}{c}2020 / 21 \\
\text { em comparação à } \\
2019 / 20 \\
\end{array}$} & \multicolumn{2}{|c|}{$\begin{array}{c}2021 / 22 \\
\text { em comparação à } \\
2020 / 21^{\mathrm{e}} \\
\end{array}$} \\
\hline & $\begin{array}{l}\text { (caixas/ } \\
\text { hectare) }\end{array}$ & & $\begin{array}{l}\text { (caixas/ } \\
\text { hectare) }\end{array}$ & $\%$ & $\begin{array}{l}\text { (caixas/ } \\
\text { hectare) }\end{array}$ & $\%$ & $\begin{array}{l}\text { (caixas/ } \\
\text { hectare) }\end{array}$ & $\%$ & $\begin{array}{l}\text { (caixas/ } \\
\text { hectare) }\end{array}$ & $\%$ \\
\hline Norte............................ & 613 & $123,6 \%$ & -502 & $-45,3 \%$ & 464 & 76,6 & -422 & $-39,4 \%$ & 251 & $38,7 \%$ \\
\hline Noroeste...... & 505 & $134,2 \%$ & -478 & $-54,2 \%$ & 520 & 128,7 & -456 & $-49,4 \%$ & 257 & $54,9 \%$ \\
\hline Centro......... & 368 & $59,7 \%$ & -277 & $-28,1 \%$ & 325 & 46,0 & -365 & $-35,4 \%$ & 149 & $22,3 \%$ \\
\hline Sul.............. & 325 & $49,0 \%$ & -218 & $-22,1 \%$ & 166 & 21,6 & -211 & $-22,5 \%$ & 56 & $7,7 \%$ \\
\hline Sudoeste.......................... & 204 & $21,5 \%$ & 41 & $3,5 \%$ & 22 & 1,8 & -111 & $-9,1 \%$ & -134 & $-12,1 \%$ \\
\hline 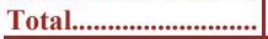 & 399 & $62,9 \%$ & -278 & $-26,9 \%$ & 289 & $38,2 \%$ & -308 & $-29,5 \%$ & 113 & $15,3 \%$ \\
\hline
\end{tabular}

Fonte: (FUNDECITRUS, 2021).

A produtividade média por hectare esperada aumentou em 15,33\% em relação à safra anterior, índice maior se comparado ao crescimento de 9,51\% que é esperado para a produção. Em relação à produtividade por setor, espera-se maior homogeneidade devido à uma queda de produtividade no Sudoeste em comparação com a safra passada e ao aumento nos demais setores.

\section{CONCLUSÃO}

No Brasil, as grandes áreas para desenvolvimento da agricultura favorecem os grandes agricultores, baixando custos com a grande escala de produção. 0 país tem fatores climáticos e naturais que favorecem o plantio dos pomares, tornando as laranjas abundantes nas fazendas e, ainda que existam também problemas climáticos inevitáveis e eventuais pragas que exigem maior atenção dos produtores, a citricultura continua em destaque na agroindústria brasileira e mundial, sendo fundamental para a economia brasileira e demonstrando compromisso com o desenvolvimento da sua cadeia de fornecimento

Este artigo evidencia a competência da indústria e o quanto a eficiência de toda a cadeia de produção do suco de laranja tem sido importante. Há méritos tanto à produção quanto à armazenagem do suco de laranja, porém, o país seria mais competitivo se sua infraestrutura obsoleta recebesse cuidados do poder público. 0 transporte para os portos feito de maneiras limitadas pode fazer com que o custo operacional aumente, influenciando diretamente o preço da mercadoria no mercado externo.

Esta pesquisa fornece base para maior exploração deste ciclo logístico por estudos que enfoquem no seu aprimoramento, tornando-o ainda mais sustentável e lucrativo. 


\section{REFERÊNCIAS}

[1]. ANJOS, T. M. dos; DUARTE, L. P; LIMA, E.S. Processo logístico da exportação de suco de laranja no Brasil. 2017. Disponível em: https://www.even3.com.br/anais/encigesp/51705processo-logistico-da-exportacao-/. Acesso em: jan. 2021.

[2]. BARAT, J. Logística e transportes no processo de globalização: oportunidades para o Brasil. Editora UNESP. São Paulo. 2007. Disponível em:

http://editoraunesp.com.br/catalogo/9788571397583,logistica-e-transporte-no-processo-deglobalizacao-/. Acesso em: jan. 2021.

[3]. CITROSUCO Produtos: FCOJ Disponível em:

http://www.citrosuco.com.br/produtos/fcoj.html. Acesso em: jan. 2021.

[4]. CITROSUCO Produtos: NFC. Disponível em:

http://www.citrosuco.com.br/produtos/nfc.html. Acesso em: jan. 2021.

[5]. CITRUSBR, Associação Nacional dos Exportadores de Sucos Cítricos. Disponível em: http://www.citrusbr.com/. Acesso em: jan. 2021.

[6]. CUTRALE. Disponível em: https://www.cutrale.com.br/contato.xhtml. Acesso em: set. 2021.

[7]. DEPEC, Departamento de pesquisas e estudos econômicos do Bradesco. 2016/2017.

Disponível em: https://www.economiaemdia.com.br/SiteEconomiaEmDia. Acesso em: jan 2021.

[8]. FONSECA, I. D.; SANTOS, G. W. M. dos; O ciclo de produção do suco de laranja FOCJ e NFC até ser embarcado para exportação pelo porto de Santos. 2019. Disponível em:

http://fateclog.com.br/anais/2019/0\%20CICLO\%20DE\%20PRODU\%C3\%87\%C3\%830\%20DO \%20SUCO\%20DE\%20LARANJA\%20FOCJ\%20E\%20NFC\%20AT\%C3\%89\%20SER\%20EMBARC AD0\%20PARA\%20EXPORTA\%C3\%87\%C3\%830\%20PEL0\%20PORT0\%20DE\%20SANTOS.pdf. Acesso em: jan. 2021.

[9]. FUNDECITRUS - Fundo de Defesa da Citricultura. Estimativa da safra de laranja 2021/22. 2021. Disponível em:

https://www.fundecitrus.com.br/pdf/pes_relatorios/2021_05_27_Sum\%C3\%A1rio_Executivo_d a_Estimativa_da_Safra_de_Laranja_2021-2022.pdf. Acesso em: jul. 2021.

[10]. FUNDECITRUS - Fundo de defesa da citricultura - Lista PIC - Disponível em: https://www.fundecitrus.com.br/busca/lista\%20pic. Acesso em: jan. 2021.

[11]. GUERISE, L. C.; Aplicação do conceito de logística integrada na exportação de açúcar e suco de laranja pelo Porto de Santos. 2006. 150 f. Dissertação (Mestrado em Organização e gestão) - Universidade Católica de Santos, Santos, 2006. Disponível em:

http://biblioteca.unisantos.br:8181/handle/tede/480. Acesso em: jul. 2021.

[12]. LOHBAUER, C. O Contencioso do Suco de Laranja entre Brasil e Estados Unidos na OMC. 2009. Disponível em: http://www.citrusbr.com/download/politicaexternasucolaranja_final.pdf. Acesso em: jan. 2021.

[13]. MAGNABOSCO, A. Fusão de Citrosuco e Citrovita Cria Novo Líder em Suco de Laranja. 2010. Disponível em: https://economia.estadao.com.br/noticias/negocios,fusao-de-citrosuco-ecitrovita-cria-novo-lider-mundial,18453e. Acesso em: jan. 2021.

[14]. MAMEDE, I. dos S. A cadeia de Suprimentos da Laranja e sua Exportação no Porto de Santos. 2018. Disponível em: https://www.even3.com.br/anais/ixfateclog/. Acesso em: jan. 2021.

[15]. MAPEIA - Cálculo de rotas. Disponível em: https://www.mapeia.com.br/. Acesso em: jan. 2021.

[16]. MARKESTRAT GROUP. Período de colheita por variedade e percentual da produção. 2010. Disponìvel em: https://www.markestrat.com.br/mks-agribusiness//. Acesso em: jan 2021. 
[17]. NEVES, M. F; TROMBIN, V. G; LOPES, F. F; KALAKI, R; MILAN, P. 0 retrato da citricultura brasileira. São Paulo. 2010. Disponível em:

[18]. https://docplayer.com.br/10644554-0-retrato-da-citricultura-brasileira.html/. Acesso em: jan. 2021.

[19]. OLIVEIRA de, S. L. - Cadeia logística do suco de laranja no Brasil -Transporte e Armazenagem- Volume 1. 2009. Disponível em: http://tcc-

fateclog.blogspot.com.br/2012/12/cadeia-logististica-do-suco-de-laranja.html. Acesso em: jan 2021.

[20]. PATTO, N.; SANTOS B. S.; TAVARES, T. D.; Exportação de suco de laranja pelo porto de Santos. 2019. Disponível em:

http://fateclog.com.br/anais/2019/EXPORTA\%C3\%87\%C3\%830\%20DE\%20SUCO\%20DE\%20 LARANJA\%20PELO\%20PORTO\%20DE\%20SANTOS.pdf.. Acesso em: jan. 2021.

[21]. PEREIRA, L. S.; SOUSA, Y. de O.; A logística envolvida no transporte de suco de laranja para a cidade de Santos. 2019. Disponível em: https://docplayer.com.br/87985728-A-logisticaenvolvida-no-transporte-de-suco-de-laranja-para-a-cidade-de-santos.html. Acesso em: jan. 2021.

[22]. PEREZ, O. C.; SANTOS, V. H. A. dos. Exportação de Suco de Laranja Brasileiro. 2014. Disponível em:

http://fateclog.com.br/anais/2019/EXPORTA\%C3\%87\%C3\%830\%20DE\%20SUC0\%20DE\%20 LARANJA\%20PELO\%20PORT0\%20DE\%20SANTOS.pdf. Acesso em: jan 2021.

[23]. PRANDO, G.; PRADO, G. E. Logística de Distribuição de Suco de Laranja Concentrado Congelado como Fator de Vantagem Competitiva. 2017. Disponível em:

http://fateclog.blogspot.com/2012/11/logistica-de-distribuicao-de-suco-de.html. Acesso em: jan 2021.

[24]. PRODANOV, C. C; FREITAS de, E. C. Metodologia do trabalho científico: métodos e técnicas da pesquisa e do trabalho acadêmico. Novo Hamburgo -RS. 2 ed. 2013. Disponível em: https://www.feevale.br/institucional/editora-feevale/metodologia-do-trabalho-cientifico---2edicao. Acesso em: jan 2021.

[25]. PORTOS E NAVIOS. Porto de Santos é líder em movimentação de suco de laranja. 2015. Disponível em: https://www.portosenavios.com.br/noticias/portos-e-logistica/porto-desantos-e-lider-em-movimentacao-de-suco-de-laranja. Acesso em: jan 2021.

[26]. RAMPAZZO, L. Metodologia Científica: para alunos dos cursos de graduação e pósgraduação. 3. ed. São Paulo: Edições Loyola, 2002.

Disponível em: https://www.amazon.com.br/Metodologia-cient\%C3\%ADfica-LinoRampazzo/dp/8515024985. Acesso em: jan. 2021.

[27]. ROJAS, P. Introdução à logística portuária: noções de comércio exterior. Porto Alegre -RS. Bookman. 2014. Disponível em: https://www.amazon.com.br/Introdu\%C3\%A7\%C3\%A3oLog\%C3\%ADstica-Portu\%C3\%A1ria-Com\%C3\%A9rcio-Exterior/dp/858260193X. Acesso em: jan. 2021.

[28]. SECEX Secretaria de Comércio Exterior. Disponível em:

http://siscomex.gov.br/legislacao/secex/.Acesso em: jan. 2021.

[29]. VIEIRA S. Sem isolamento para a laranja brasileira. Revista Dinheiro Rural, edição no 177 , 2020. Disponível em: https://www.dinheirorural.com.br/sem-isolamento-para-a-laranjabrasileira/.Acesso em: jan. 2021. 


\section{Capítulo 9}

Cargas especiais: Estudo do transporte de cargas congeladas no Brasil

\section{Danilo Germano Santos \\ Josué Elias de Souza Júnior \\ Lucas Fernando de Oliveira Fonseca}

Resumo: Este estudo aborda as operações logísticas no transporte da carga especial congelada, relacionando também a cadeia do frio e suas respectivas necessidades, evidenciando os procedimentos envolvidos em seu transporte, armazenagem e distribuição. Assim, após pesquisas de caráter bibliográfico e analítico de forma qualitativa e quantitativa constatou-se sua relevância e importância e seus procedimentos ocorridos no desencadeamento de seu transporte. 0 trabalho caracteriza a cadeia do frio e o funcionamento da logística do transporte de produtos congelados, trazendo à tona o entendimento da importância da manutenção e das condições ideais para o transporte do produto especial congelado.

Palavras-chave: Cargas especiais. Cargas congeladas. Cadeia de Frio. 


\section{INTRODUÇÃO}

Todos os dias, cargas são transportadas para todos os cantos do Brasil e para o exterior a todo instante, mas um tipo especial de carga que precisa de uma certa atenção, essa é a carga perecível, e algumas dessas em específico necessitam de temperaturas extremamente baixas para que o produto seja transportado adequadamente de um ponto até outro. Segundo a NBR 14701 (ABNT, 2001), é imperativo baixar e estabilizar a temperatura interna da câmara pelo menos 15 minutos antes da entrada do produto alimentício. Também é necessário usar instrumentos para registrar continuamente a temperatura do ar no ambiente durante o transporte. Dentre os produtos congelados destacam-se os peixes e as carnes bovinas e avícolas. Segundo dados do Comex Stat (2020) esses mesmos produtos congelados, estão entre os mais exportados pelo país, e no ano de 2019, representaram cerca de U\$12,2 bilhões em exportações no Comércio Exterior do Brasil, mesmo que estes produtos não recebam a mesma atenção que soja, café ou outros.

De acordo com o Ministério da Agricultura, Pecuária e Abastecimento, o produto deve ser submetido a um processo de congelamento para reduzir sua temperatura a um grau suficientemente baixo para manter sua qualidade, mantendo-o a essa temperatura durante o transporte, armazenamento e distribuição, incluindo o momento da venda.

Mudanças no estilo de vida nas últimas décadas levaram ao aumento do consumo de alimentos refrigerados e congelados. Isso ocorre devido às vantagens que esses tipos de produtos podem proporcionar, como: facilidade de preparo, agilidade, sensorial, retenção das propriedades físicas e sensoriais, aumento da validade, entre outros. Além desta demanda crescente, há uma demanda crescente de consumidores que buscam produtos de alta qualidade. Esses dois fatores estão mudando a indústria, levando a uma maior regulamentação e controle desse tipo de cadeia de suprimentos que inclui o controle de temperatura. (BOGATAJ, 2005 e COULOMB, 2008).

Este trabalho de pesquisa tem por objetivo geral fornecer uma compreensão das operações logísticas envolvidas no transporte de um produto especial no setor de produtos congelados e as razões pelas quais são consideradas tão complexas. Por objetivo específico, é importante compreender quais são os procedimentos básicos para o transporte deste tipo de produto e quem são as pessoas envolvidas no transporte.

A metodologia científica é a aplicação prática de um conjunto de procedimentos objetivos. Os pesquisadores usam os procedimentos objetivos para desenvolver experimentos para gerar novos conhecimentos e integrá-los aos existentes. Portanto, inclui etapas dispostas de maneira lógica e coerente, e os pesquisadores devem conhecer essas etapas e aplica-las corretamente. Essas etapas incluem, de forma concisa, desde a seleção do tema a ser estudado, o plano da pesquisa, o desenvolvimento do método selecionado, a coleta e tabulação dos dados, a análise dos resultados, a elaboração das conclusões e a divulgação das informações e resultados. A fase de revisão bibliográfica do tema do projeto de pesquisa visa, em primeiro lugar, fundir o aluno com as nuances do tema proposto, proporcionar-lhe uma compreensão mais aprofundada do trabalho a ser realizado, e permitir que pesquisadores e alunos reflitam sobre temas relacionados. Compara com os resultados obtidos por outros autores. Em segundo lugar, assume o papel de trazer os leitores para o mundo científico de disciplinas relacionadas, apresentando notícias de sucessos e fracassos com temas semelhantes. Terceiro, mostra que os pesquisadores são as pessoas mais atualizadas sobre as últimas discussões de pesquisa (FONTELLES, 2009). 


\section{FUNDAMENTAÇÃO TEÓRICA}

A Cadeia de Produção é a conjunção de corporações, sendo as empresas principais organizações da Cadeia de produção, seu desenvolvimento, como atividades, serviços prestados e produtos se sucedem como elos de uma mesma cadeia, seguindo uma sequência de todo o ciclo de produção de um determinado produto ou serviço. Incluindo todas as etapas do ciclo de produção, desde o fornecimento de insumos básicos até a entrega de um produto ou serviço a determinado consumidor, cliente ou usuário final, também como as respectivas organizações pertencentes aos segmentos de produção da cadeia produtiva. (BRASIL, 2000).

A cadeia produtiva é caracterizada pela conjunção de atividades econômicas que estão ligadas entre si de forma que compõem o desenvolvimento progressivo desde a criação do produto. Incluindo desde a matéria prima, insumos, equipamentos e maquinários, componentes, produtos intermediários ao produto acabado, a distribuição, a comercialização e a inserção do produto final no mercado para o consumidor. (INSTITUTO BRASILEIRO DA QUALIDADE E PRODUTIVIDADE, 1999).

De acordo com Poirier \& Reiter (1997), a cadeia de suprimentos é um sistema através do qual empresas e organizações podem fornecer produtos e serviços a seus consumidores em uma rede de organizações interconectadas.

A cadeia inclui todas as fases envolvidas no atendimento direto ou indireto dos pedidos dos clientes, abrangendo não apenas fabricantes e fornecedores, mas também transportadores, armazéns, varejistas e os próprios clientes (CHOPRA; MEINDL, 2004).

Lambert, Stock e Valentine (1998) acreditam que o sistema de processamento de pedidos é o ponto nevrálgico da cadeia de suprimentos, pois é um meio de comunicação para iniciar todo o processo logístico. Dessa forma, a velocidade e a qualidade do fluxo de informações afetam diretamente o custo e a eficiência das operações globais. (Figura 1):

Figura 1 - Processamento de Pedidos

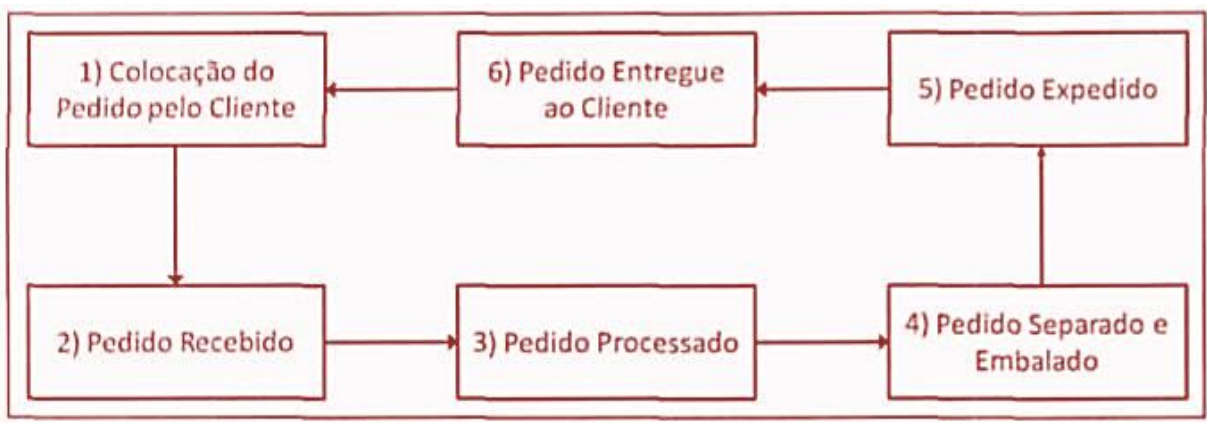

Fonte: Lambert et al. (1998)

Christopher (1997) também propôs esse ciclo, defendendo que o cliente tem apenas um prazo: o tempo decorrido desde o pedido até a entrega do produto. Do ponto de vista do fornecedor, esse período nada mais é do que a conversão do capital em dinheiro.

Segundo Fleury (2004), no Brasil, a gestão da cadeia de suprimentos (SCM) começou a se espalhar em meados da década de 1990. Isso ocorreu devido ao movimento de logística 
integrada em evolução no país, que aprofundou o relacionamento com os fornecedores selecionados e suas necessidades e clientes com quem é estabelecida uma parceria.

O armazenamento é considerado uma função importante para resolver com eficácia o gerenciamento da cadeia de suprimentos. Seu significado é que se trata de um sistema de abastecimento relacionado ao fluxo logístico, que é a base de sua unidade e continuidade, podendo garantir níveis de serviço adequados e agregar valor aos produtos (BARROS, 2005).

Na cadeia, o fluxo principal do produto (principalmente unidirecional) requer um fluxo coordenado simultâneo, como pedidos, pagamentos e principalmente informações (LAMBIN, 2002).

Portanto, nesse processo, será determinado qual relação entre consumidores, fornecedores e prestadores de serviço é mais ou menos importante na otimização do SCM (COLLINS et al., 1997).

Para promover a melhoria da organização da cadeia de suprimentos, são propostos os principais elementos de melhoria: desenvolvimento do produto, gestão da demanda e fornecimento integrado (PARRA; PIRES, 2003).

Para Handabaka (1994), a carga unitária é o agrupamento de um ou mais itens de uma carga geral a serem manuseados como uma única unidade indivisível. Carregar, descarregar e movimentar materiais é um esforço que cada área de distribuição deve realizar em suas operações, mas essas atividades não agregam valor aos produtos, apenas aumentam os custos. O custo unitário é facilmente compensado por custos operacionais mais baixos.

Segundo Souza (1993), a padronização das cargas deu origem à ideia de minimizar custos, aumentando a segurança das mercadorias, sem falar na facilidade de manuseio dos produtos.

Carga indivisível é aquela que não pode, sem custo excessivo ou risco de avaria, ser dividida em duas ou mais partes e que, para efeito de transporte, supera o peso e / ou dimensões dos veículos convencionais, conforme Resolução 210/06 (CONTRAN, 2006). Portanto, a carga transportada deve ser manuseada com mais cuidado, pois se trata de materiais volumosos que requerem cuidados especiais devido ao alto grau de perigo. Essas fogem da padronização e unitização de cargas.

Para Sobral (2006), os paletes são dispositivos de unitização de carga concebidos para melhorar a movimentação mecânica na produção industrial, em armazéns e tendem a melhorar os meios de transporte durante a carga e descarga.

Bertaglia (2005) afirma que o palete é uma base de metal, madeira ou fibra destinada a ser movida mecanicamente por empilhadeiras, porta-paletes, guindastes, caminhões hidráulicos ou veículos similares. As principais vantagens de sua utilização são a redução de recursos nas etapas logísticas de armazenamento, transporte e manuseio, bem como maior agilidade na carga e descarga.

Já Keedi (2005) afirma que o palete pode ser entendido como qualquer estrutura adequada para conter uma carga, feita de madeira, plástico, metal, fibra, papelão ou qualquer material que se adapte ao uso pretendido e não interfira na carga seja ela de sólidos, líquidos, gasosos, químicos, alimentícios, secos, resfriados etc. Essa estrutura é construída para servir de piso para mercadorias que nela ficarão unidas até certo tempo. 
Segundo Campos e Rissardo (1987), transportes de cargas especiais são definidos como todos os veículos de carga que excedam as dimensões e / ou peso máximos previstos em lei ou que possuam propriedades físicas / operacionais que afetem adversamente a segurança e a fluidez do tráfego.

0 transporte de carga geral corresponde ao manuseio de quantidades fracionadas e embaladas, bem como de grandes quantidades unitárias sem embalagem. Abrange também o transporte de cargas especiais, aquelas que requeiram cuidados variados e especiais. Exemplos de cargas especiais são: congeladas, refrigeradas, perigosas e vivas (RODRIGUES, 2007).

Conforme (ABNT,TB-352, item 3.5.5) carga perecível é uma carga composta por produto passível de deterioração ou composição que exige condições especiais de temperatura e/ou arejamento para manutenção de suas características orgânicas.

Então, para Pinto e Neves (2010), em mercadorias perecíveis, deve-se ter responsabilidade pelas mercadorias que chegam ao destino final em bom estado. 0 investimento e o risco são altos, é necessário equipar câmara fria e equipamentos de refrigeração. Devido ao sistema de resfriamento, isso aumentará muito o consumo de combustível. Outro item a ser considerado é a necessidade constante de limpeza dos veículos.

\section{CADEIA DO FRIO}

Cadeia do Frio é compreendida por todo processo de armazenagem, preservação, distribuição, movimentação e manipulação dos produtos refrigerados e congelados, utilizando a baixa temperatura controlada. Caso ocorra qualquer falha nesta cadeia a qualidade dos produtos poderá ser comprometida, de forma que a velocidade das reações químicas, bioquímicas e microbiológicas estão totalmente ligadas a temperatura, podendo reduzir a qualidade dos produtos refrigerados, sendo estas a redução na qualidade nutricional e sensorial. Com isto, constata-se que garantir a estabilidade e constância da cadeia do frio, operando de forma correta desde o produtor até sua chegada ao consumidor final é algo de extrema importância.

0 Brasil transformou-se em entre os maiores produtores mundiais da carne de bovinos, aves e suínos, com uma exportação aproximada, em 2014 de 6,25 milhões de toneladas desses três commodities (ABPA, 2015).

Segundo Brand (2014), nos últimos tempos houve uma nítida mudança no transporte de produtos perecíveis do transporte aéreo para o marítimo, em contêineres refrigerados.

De acordo com Heidmann et al. (2013), considerando as mudanças de temperatura no decorrer do processo de carga e descarga e até mesmo no processo todo, o transporte de caminhões refrigerados pode se tornar um ponto chave na degradação na qualidade de cargas perecíveis, no urbano e interurbano.

Então, de acordo com Tingman et al. (2010), aproximadamente um terço dos alimentos frescos é descartado por conta de condições inadequadas de saneamento e manutenção nas fases de distribuição.

0 entendimento geral é que quanto maior a distância percorrida de produtos congelados, ainda mais cuidados devem ser tomados para evitar a interrupção da cadeia de frio, enquanto viagens curtas não requerem grande atenção. Esse raciocínio faz com que as viagens curtas sejam mais críticas para a manutenção da cadeia de frio. Para 
contornar esse raciocínio, foram ministrados treinamentos e desenvolvidos procedimentos de conscientização dos diversos intervenientes da cadeia de frio (HEAP, 2006).

\subsection{PRODUTOS PERECÍVEIS CONGELADOS}

A grande maioria dos produtos perecíveis requer resfriamento contínuo e ininterrupto para a sua preservação, bem como um ambiente controlado em termos de umidade e ar e composição, durante os processos de armazenamento e transporte. Devido à refrigeração, mudanças microbiológicas, fisiológicas e físicas nos alimentos na póscolheita processos podem ser completamente evitados ou significativamente reduzidos. (Haas, Dittmer, Veigt, e Lutjen, 2015).

Como alimentos perecíveis facilmente se deterioram, qualquer desvio de condições precisamente definidas (por exemplo, temperatura, pressão barométrica, composição do ar, umidade) podem potencialmente levar a perdas e danos aos alimentos (Aung e Chang, 2014; Rong, Akkerman, e Grunow, 2011).

Mudanças na condição e qualidade da carga perecível, bem como atrasos no transporte, podem causar rejeições de remessas, cujo número aumentou recentemente. a razão subjacente para isso pode ter a ver com a cada vez mais rigorosa e rápida mudanças nos padrões de segurança alimentar, bem como a capacidade crescente de fiscalização. (Jaffee e Henson, 2005) embora isso também possa surgir das políticas dos varejistas tradicionais de aceitar apenas produtos com uma alta (geralmente mais de $70 \%$ ) do prazo de validade restante destes produtos. (Mena, Adenzo-Diaz, e Yurt, 2011).

Os requisitos específicos de perecíveis se traduzem diretamente na tecnologia e a complexidade organizacional das cadeias de frio e impõem critérios exigentes para as partes envolvidas na logística da cadeia de frio. Além disso, o natureza global do comércio de produtos perecíveis, ou seja, longas distâncias e tempos de trânsito, muitos pontos de transbordo, e muitas partes envolvidas na organização e manipulação de trânsito, também aumenta a probabilidade de quebrar o que é conhecido como integridade da cadeia de frio. Sem considerar do grau de complexidade da cadeia de frio, conformidade com os requisitos específicos que a carga perecível deve ser garantida em todas as fases desta cadeia. (Aung e Chang, 2014).

\subsubsection{EMBALAGENS PARA PRODUTOS PERECÍVEIS CONGELADOS}

Segundo a Agência nacional de Vigilância Sanitária (ANVISA) embalagem para alimento é qualquer revestimento, recipiente, qualquer forma de acondicionar, sendo removíveis ou não, destinada a empacotar, cobrir, envasar, proteger ou manter, podendo ser especificamente matérias-primas, produtos semiacabados ou produtos acabados. (RIBEIRO et al., 2008).

Para as empresas além de proteger durante o armazenamento e o transporte, as embalagens e os rótulos também servem como um meio de comunicação entre o produto e o consumidor. Os rótulos têm maior destaque por conseguirem agregar maior valor a marca, de forma que as diferenciem no mercado e dentre os consumidores. (SILVEIRA NETO, 2001 apud GONÇALVES; PASSOS; BIEDRZYCKI, 2008).

A embalagem consiste em um recipiente responsável por envolver e acondicionar determinado produto, com o objetivo de protegê-lo no transporte contra impactos, 
vibrações, compressões, protegendo-o no manuseio e na distribuição. (CABRAL et al., 1984).

A embalagem deve controlar e adequar a fatores externos como a umidade, oxigênio e luz, de forma que impeça o desenvolvimento de micro-organismos no produto. Desta forma garantindo a segurança e qualidade do produto, também prolongando sua vida útil. (CABRAL et al., 1984).

Dentre os principais termoplásticos utilizados na embalagem de alimentos estão o polietileno (PE), polietileno tereftalato (PET), policloreto de vinila (PVC), poliestireno (PS) e o polipropileno (PP). (CABRAL et al., 1984).

0 polietileno (PE) é o material plástico transparente mais barato e mais vendido no mundo. Sua característica mais relevante é a sua densidade, de forma, que quanto maior a densidade, maior a sua resistência mecânica, temperatura e barreira. E quanto menor a sua densidade, maior é a resistência ao impacto. Sua flexibilidade e resistência são fatores de alta relevância para as opções de embalagens (CABRAL et al., 1984).

Principais aplicações (CABRAL et al., 1984):

- Carnes: utilizado na forma de envoltório para carnes frescas, devido à alta permeabilidade ao oxigênio, tanto na forma de filme como em embalagens termoencolhíveis.

Também são usados para embalar carne e frango congelados, por apresentar excelente comportamento em baixas temperaturas;

- Frutas e vegetais frescos: as embalagens de frutas e vegetais de polietileno devem ser perfuradas para evitar o acúmulo de umidade na superfície interna, por sua baixa permeabilidade ao vapor da água; os filmes de polietileno, juntamente com outros plásticos, também são usados para empacotar produtos alimentícios secos como cereais, farinhas, café, leite em pó e usados nos rótulos de refrigerantes, óleos, principalmente em PET (CABRAL et al., 1984).

\section{TRANSPORTE DE CONGELADOS}

Produtos que serão colocados em transporte devem, de forma obrigatória, ter suas temperaturas reduzidas antes de sua entrada na câmara (HEAP, 2006), pois o sistema de refrigeração utilizado no transporte de alimentos congelados e resfriados não foram projetados para reduzir a temperatura dos produtos, mas sim para acondicionar mantendo a temperatura. (MERCANTILA, 1989).

Segundo a NBR 14701 (ABNT, 2001), a temperatura na câmara deve obrigatoriamente ser reduzida e estabilizada pelo menos 15 minutos antes da entrada do produto alimentício. 0 instrumento também deve ser usado para registrar continuamente a temperatura do ar interno ao decorrer do processo de transporte.

Os veículos de transporte sob temperatura controlada são definidos como veículos de transporte com ar-condicionado (cf. Regulamento n. ${ }^{\circ}$ 682/96 de 21 de novembro) e podem ser distinguidos em isotérmicos, refrigerados, frigoríficos e caloríficos. A diferença entre os veículos refrigerados e os frigoríficos é essencialmente a natureza do frio, sendo um veículo frigorífico aquele que utiliza dispositivos mecânicos ou de absorção para produzir o frio. 
A refrigeração da câmara pode ser estática ou ventilada (Figura 1), ou seja, o movimento complexo do ar dentro do espaço condicionado é suportado apenas pela ação natural dos efeitos térmicos do pulso (câmara de convecção natural) ou pelo uso de ventiloconvectores para aumentar a circulação de ar (câmaras de convecção forçada). As fontes de resfriamento mais utilizadas em câmaras com resfriamento estático são as placas eutéticas, que permitem obter temperaturas de operação padrão em torno de -50 ${ }^{\circ} \mathrm{C}$ a $-3{ }^{\circ} \mathrm{C}$. Nessa técnica, as placas instaladas nos pontos mais altos da câmara da câmara (teto ou paredes laterais) são preenchidas com um refrigerador secundário resfriado pelo trocador por onde circula o refrigerador principal. Para sistemas de expansão direta, esta bobina é o evaporador do grupo de resfriadores. (Gaspar; Pitarma, 2003).

Figura 1 - Representação esquemática de câmaras frigoríficas de veículos.

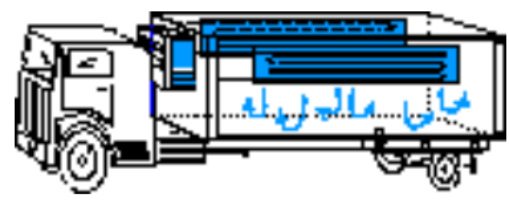

a) Refrigeração estática (convecção natural).

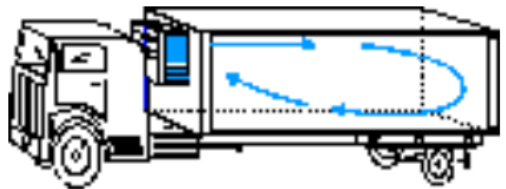

b) Refrigeração ventilada (convecção forçada).

Fonte: Gaspar \& Pitarma (2003)

Gaspar \& Pitarma (2003) continuam argumentando que as câmaras de ar refrigerado de circulação forçada fazem uso de sistemas de ventilação mecânica para promover o sopro na câmara após o ar passar pelo evaporador de um grupo de refrigeradores. 0 uso desta técnica implica uma circulação de ar em circuito fechado, dutos ou luvas são frequentemente usados para distribuir o ar em veículos longos. As taxas de fluxo de ar para veículos longos com compartimentos convencionais são próximos a 60 renovações / hora, enquanto para veículos longos com geladeiras de paredes finas, são sugeridas renovações a cada 80 a 90 horas.

0 equipamento de refrigeração não tem capacidade suficiente para retirar a carga térmica, esta causada pela entrada de ar quente, que adentra quando as portas das câmaras são abertas. Por isto é essencial que o número de abertura de portas seja o mínimo possível (TRESSLER, 1968).

Enquanto o carregamento e o descarregamento dos produtos na câmara, o sistema de refrigeração deverá estar desligado, para assim diminuir o uso de combustível e evitar a necessidade da realização de degelos (HIRA, 2001), pois, com os ventiladores do evaporador desligados, ocorrerá a menor substituição do ar frio do ambiente interno pelo ar quente e úmido do ambiente externo, fazendo com que o ar quente prevaleça.

O carregamento e descarregamento podem ser os momentos mais críticos para a conservação dos produtos refrigerados e congelados, caso essas etapas não sejam executadas corretamente em curto tempo. (IIR, 2006). Sempre que a porta da câmara é aberta ocorre a troca do ar refrigerado pelo ar quente e úmido (IIR, 1986). As portas das câmaras somente podem permanecer aberta durantes entregas, devendo estar fechadas o máximo possível. (HIRA, 2001). 


\subsection{CONDIÇÕES DE TRANSPORTE}

No Estudo White (2007) sobre o monitoramento do transporte refrigerado de produtos alimentícios perecíveis, foi demonstrado que a elevação de temperatura acima da temperatura especificada ocorre em 30\% das idas do fornecedor ao Centro de Distribuição e em 15\% dos Centros de distribuições aos locais onde os produtos são comercializados.

Como é defendido por Ashrae (1994), os veículos de transporte orientados pela temperatura se enquadram em três grupos principais, dependendo de seu uso: transporte de longa distância, transporte de curta ou média distância e veículos de distribuição de produtos alimentares. Outra subclassificação pode ser feita em relação temperatura de serviço: baixas temperaturas ou produtos congelados, [-18 $\left.{ }^{\circ} \mathrm{C}\right]$; produtos

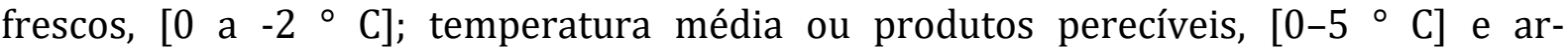
condicionado: [13-21 $\left.{ }^{\circ} \mathrm{C}\right]$.

Para que desenvolvimento do congelamento seja eficaz, ele requer temperaturas de $18^{\circ} \mathrm{C}$ ou menos, prestando atenção ao processo de congelamento e à temperatura, ou seja, se o congelamento de produtos alimentícios é lento ou rápido, a velocidade de circulação do ar, o tamanho e forma da embalagem e o tipo de alimento (PEREIRA, 2011).

Produtos alimentícios perecíveis submetidos a baixas temperaturas, abaixo de $0^{\circ} \mathrm{C}$, passam por um processo de congelamento, cuja causa é verificada pelo efeito de solidificação da água contida no produto, sabendo que a maioria dos alimentos contém, entre outros, de $60 \%$ a $80 \%$ de água, substâncias orgânicas e minerais (FERNANDES, 2015).

Figura 2 - Curva típica de congelação de um alimento

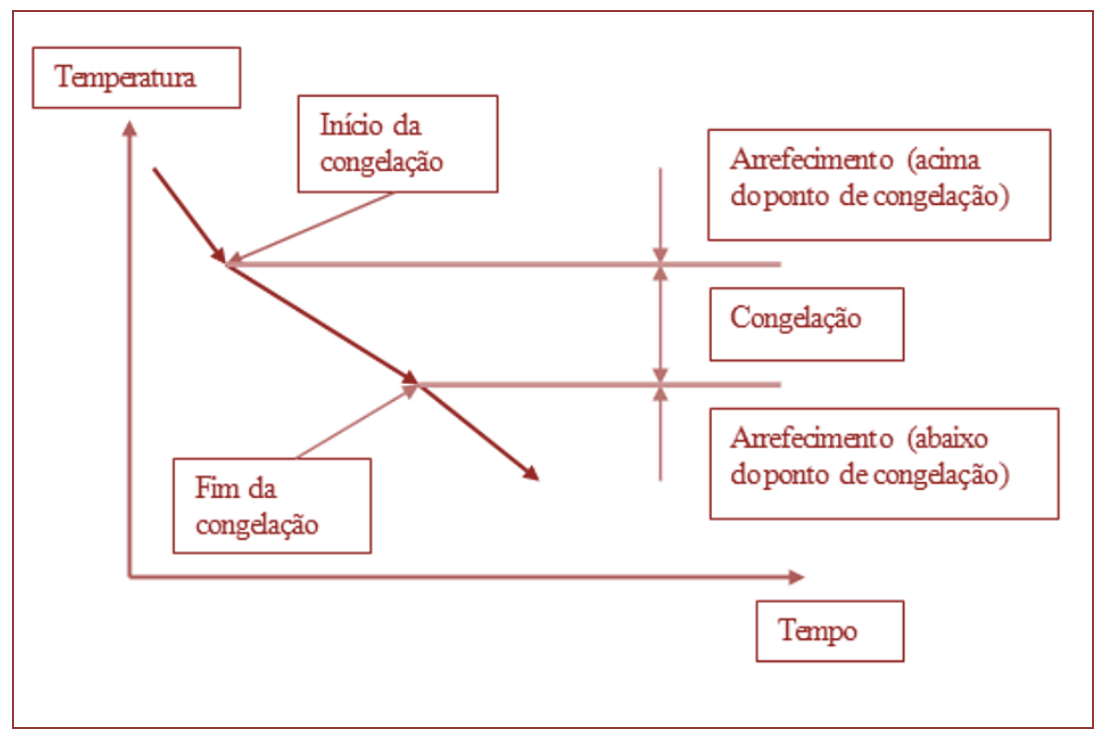

Fonte: Çengel e Boles (2001)

Fernandes (2015) adiciona ainda que a refrigeração de alimentos envolve o arrefecimento de alimentos sem variação de fase, enquanto o congelamento envolve três etapas: arrefecimento até o ponto de congelamento (perda de calor sensível); 
congelamento (perda de calor latente) e posterior arrefecimento até a temperatura desejada (perda de calor sensível dos alimentos congelados).

\section{ARMAZENAMENTO DE CONGELADOS}

A fase de armazenamento do produto é extremamente importante em todo o processo da cadeia. A necessidade de manter a temperatura e umidade do produto em um ambiente qualificado é de grande importância para manter a qualidade íntegra do produto. Nesse contexto, demonstra-se a notabilidade do armazenamento refrigerado no cenário atual, porém, de acordo com Mello et al. (2011), o Brasil tinha cerca de apenas 2 milhões de metros cúbicos de câmara fria em 2010. Se Comparado aos 48 milhões que possuíam os Estados Unidos, é um número relativamente baixo, e Japão que embora possua um território bem menor que o Brasil, ainda assim possuía cerca de 22 milhões de metros cúbicos.

Em relação ao armazenamento, Embrapa (2000) afirma que o local de armazenamento de cargas congeladas deve ser munido com equipamentos adequados para manter continuamente as condições de temperatura e umidade necessárias para a preservação adequada dos alimentos. Os espaços de armazenamento de alimentos congelados devem ser equipados com instrumentos que possam controlar (preferencialmente registrar) as condições de temperatura e umidade do ar. As verificações de temperatura devem ser realizadas frequentemente, de preferência com um termovisor ou equipamento que faça o monitoramento contínuo das temperaturas de armazenamento. A velocidade do ar no compartimento frigorífico deve ser moderada e não deve exceder a velocidade necessária para atingir uma temperatura suficientemente uniforme no compartimento frigorífico. Os produtos devem ser empilhados para não obstruir a circulação do ar. Na câmara fria, procedimentos de limpeza e manutenção de descongelamento devem ser estabelecidos para evitar congelamento e bloqueio dos difusores de ar. A porta e passagem da câmara devem ser equipadas com cortina de ar ou cortina de plástico.

0 armazenamento desta categoria de produto é dividido em três:

\section{Procedimentos básicos:}

- Armazenamento sob congelamento: a etapa na qual o congelamento dos alimentos é levado à temperatura de $0^{\circ} \mathrm{C}$ ou menos, conforme o recomendado pelos fabricantes na rotulagem ou nos critérios de uso padrão.

- Armazenamento sob refrigeração: a etapa onde os alimentos são armazenados a uma temperatura de $0^{\circ} \mathrm{C}$ a $10^{\circ} \mathrm{C}$, conforme o recomendado pelos fabricantes na rotulagem ou nos critérios de uso padrão.

- Estoque seco: a etapa onde os alimentos são armazenados a uma temperatura ambiente, conforme o recomendado pelos fabricantes na rotulagem ou nos critérios de uso padrão. (SEARA, 2015).

A estrutura ideal para o armazenamento de alimentos deve ser a composta por um lugar onde não deve haver nenhuma insalubridade, nenhum lixo, objetos em desuso, bem como animais, insetos e roedores, a área próxima não deve fornecer condições para a reprodução destes mesmos. 0 chão deve ser constituído de um material liso, durável, à prova d'água, lavável, de cor clara e apresentar um alto estado de conservação. É de suma importância que seja e altamente resistente ao ataque de substâncias corrosivas e de fácil de higienização (lavagem e desinfecção), que não permita nenhum acúmulo de restos de comida, resíduos ou sujeiras. As paredes também devem ser constituídas de um material liso, durável, à prova d'água, lavável, de cor clara, bem como o chão, e 
devem ser livres de mofos ou fungos (bolores) e apresentar um alto estado de conservação se tiver ladrilhos, sua altura mínima deve ser dois metros, ângulos arredondados no contato com o piso e o teto. (SEARA, 2015).

Deve haver uma área única separada do armazém principal destinada para coleta ou inutilização de produtos. A vasão interna por meio de ralos deve ser evitada. Quando necessário, deve ser sifonado e coberto para evitar a entrada de pragas e odores desagradáveis. A pia e o banheiro devem ser isolados da estocagem de alimentos. (EMBRAPA, 2000).

No que diz respeito à iluminação. Ela deve ser uniforme, sem ofuscamentos e também não pode haver contraste excessivo, sombras e vinhetas. As lâmpadas e os demais equipamentos de iluminação devem estar limpos, protegidos contra explosões e quedas acidentais e no melhor estado de conservação possível, sendo que não devem alterar as características sensoriais dos alimentos. (SEARA, 2015).

\section{RESULTADOS E DISCUSSÃO}

Segundo a Kantar Worldpanel (2017), a categoria de alimentos congelados cresceu 24\% em receita e $17 \%$ em volume em relação a 2014 e 2013. 0 consumidor passa a escolher novos atributos, como preço e promoção, praticidade e comodidade, e só então surgem marcas que facilitam a entrada de novas empresas no negócio.

Segundo o SEBRAE (2020), entre 2013 e 2019 Dados da consultoria Euromonitor indicam que as vendas de pratos prontos congelados em 2013-2019 são de 85,4\%. Segundo dados da Abimapi, o consumo per capita de massas e biscoitos congelados no Brasil é de 17,2 kg por ano. "Ainda há muito espaço para aumentar o consumo de massas no Brasil." (Cláudio Zanão, presidente da Abimapi) Nosso consumo per capita é o $20^{\circ}$ no ranking mundial. A frequência de compras em massa por semana ainda é muito baixa no país devido à barreira cultural que pode ser superada revelando receitas e produtos.

Para efeito de comparação no comércio exterior, foi feita uma pesquisa utilizando dados do Comexstat (2020) com uma comparação do ano de 2009 até 2019 comparando a importação, exportação de cargas congeladas.

Para a seleção dos produtos pesquisados foi utilizado o Sistema Harmonizado (SH4), esses foram:

0202 - Carnes de animais da espécie bovina, congeladas;

0203 - Carnes de animais da espécie suína, frescas, refrigeradas ou congeladas;

0204 - Carnes de animais das espécies ovina ou caprina, frescas, refrigeradas ou congeladas;

0303 - Peixes Congelados, exceto os filés de peixes e outras carnes de peixes da posição 03.04 . 
Gráfico 1 - Comparativo em Quilogramas (2009-2019)

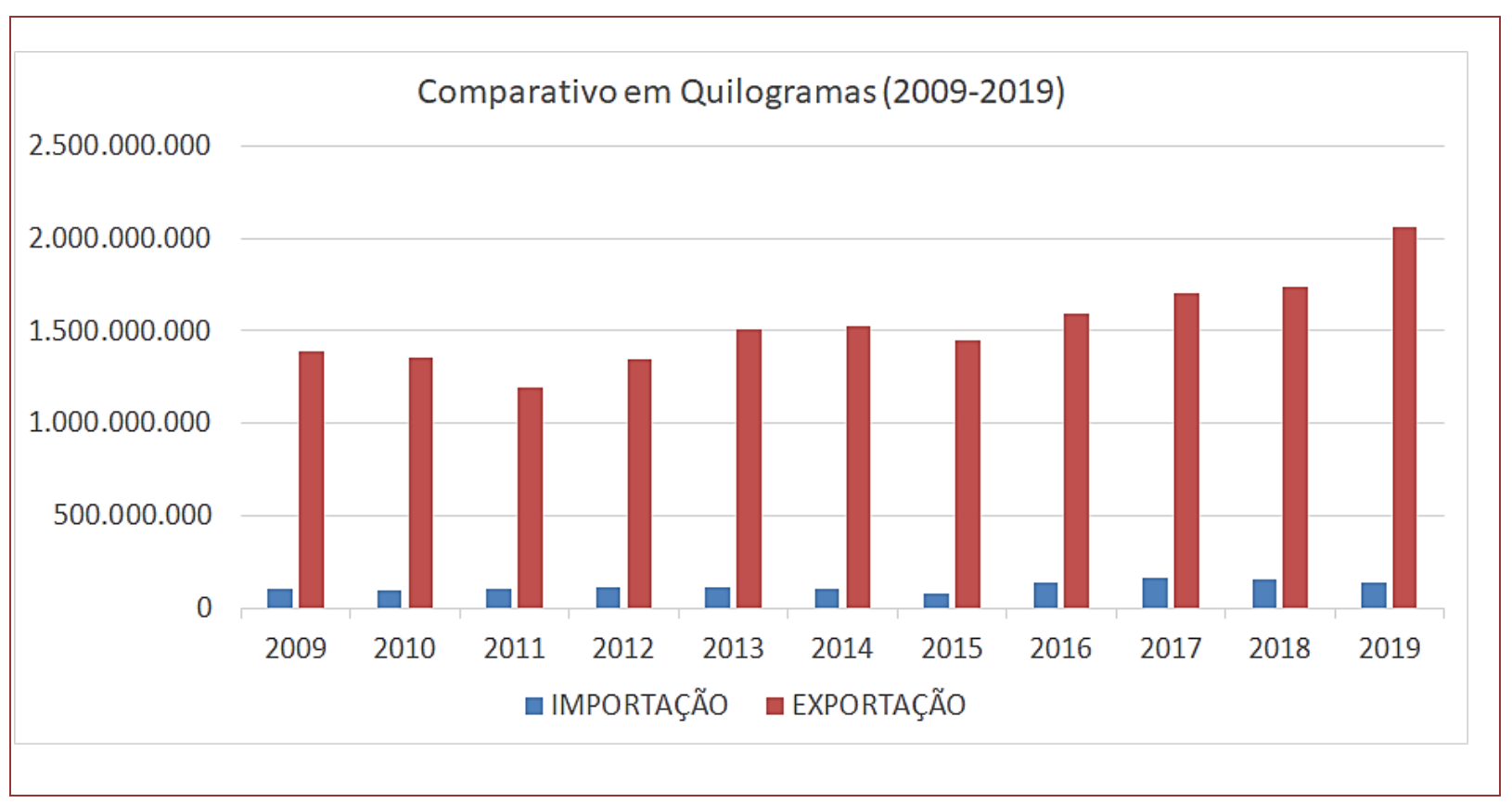

Fonte: Comexstat (2020)

De acordo com o gráfico, a exportação é desproporcionalmente maior que a importação, tendo sua maior marca no ano de 2019, isso se deve pelo fato de que a importação do Brasil em relação a esses produtos é o suficiente para que o país forneça para outros países e atenda a demanda interna.

\section{CONSIDERAÇÕES FINAIS}

Este trabalho buscou apresentar maior compreensão a respeito das operações logísticas envolvidas no transporte de Cargas Especiais Congeladas, para isto, foram reunidas evidências dos respectivos processos no transporte de cargas especiais, sua necessidade e atenção. Demonstrando também a base de seu desenvolvimento que é a Logística no transporte de cargas, dando ênfase no transporte da carga congelada. Fazendo com que evidencie os processos da Cadeia do Frio, como, o seu transporte, sua respectiva condição de alocação e condições adequadas para que todo o processo logístico seja efetuado. 0 trabalho caracteriza a cadeia do frio e o funcionamento da logística do transporte de produtos congelados, visando assim entender a importância da manutenção e das condições ideais de transporte do produto congelado. Ficou claro o quão necessário é o condicionamento e o cuidado necessário com esse tipo de carga, não apenas durante o transporte, mas durante todo o processo pelo qual o produto passa até chegar no consumidor final. Além disso, pudemos compreender que o Brasil é uma grande potência na movimentação desse tipo de produto, sendo capaz de exportar para diversos países e suprir a necessidade interna desses mesmos produtos. 


\section{REFERÊNCIAS}

[1]. AUNG, M., and Chang, Y. (2014). Temperature management for the quality assurance of a perishable food supply chain. Food Control, (40), 198-207.

[2]. ASHRAE - ASHRAE Handbook: Refrigeration - Systems and Applications, (SI Edition). American Society of Heating, Refrigerating and Air-Conditioning Engineers, Inc., 1994.

[3]. ASSOCIAÇÃO BRASILEIRA DE NORMAS TÉCNICAS - ABNT. NBR 14701. Transporte de produtos alimentícios refrigerados: procedimentos e critérios de temperatura. Rio de Janeiro, 2001. $7 \mathrm{p}$

[4]. ASSOCIAÇÃO BRASILEIRA DE PROTEÍNA ANIMAL - ABPA. Relatório anual. São Paulo: ABPA, 2015. Disponível em: . Acesso em: 10 out 2020.

[5]. BARROS, Nivia Valença. Curso: Capacitação para Conselhos Tutelares - Projeto SIPIA Ministrado na Faculdade de Administração - Niterói/UFF, 14, 15 e 17 de julho de 2005.

[6]. BERTAGLIA, P. R. Logística e gerenciamento da cadeia de abastecimento. São Paulo: Saraiva, 2005.

[7]. BOGATAJ, Marija.; Bogataj, Ludvik. e Vodopivec, Robert. Stability of Perishable Goods in Cold Logistics Chains. International Journal of Production Economics, 2005.

[8]. BRAND, D. Mode shift in perishables. [s.l.]: [s.n.], 2014. Disponível em:<http://ipaper.ipapercms.dk/MCI/Various/SeaburyModeshiftinperishables/?page=1>. Acesso em: 15 out 2020.

[9]. BRASIL. Ministério do Desenvolvimento, Indústria e Comércio. Termo de referência de tecnologia de gestão do uso do poder de compra: Projeto Formação de recursos humanos especializados na tecnologia de gestão do uso do poder de compra. Brasília: MDIC: SEBRAE, 2000.

[10]. BRASIL - Ministério da Agricultura, Pecuária e Abastecimento. Secretaria Especial da Aqüicultura e da Pesca. Manual de Procedimento para Implantação de Estabelecimento Industrial de Pescado. Brasília: 2007.

[11]. CABRAL, Antonio Carlos Dantas et al. Apostila de embalagem para alimentos. Campinas, 1984.

[12]. CAMPOS, L P. G.; RISSARDO, A. C. Tipos de Transportes Especiais de Cargas - Companhia de Engenharia de Tráfego. São Paulo, 1987

[13]. CHOPRA, Sunil; MEINDL, Peter. Gerenciamento da cadeia de suprimentos. Estratégia, planejamento e operações. Ed. Peasson/ Pentice Hall. São Paulo. 2004.

[14]. CHRISTOPHER, Martin. Logística e gerenciamento da cadeia de suprimentos: estratégias para a redução de custos e melhoria de serviços. São Paulo: Pioneira, 1997.

[15]. COLLINS, R. S.; BECHLER, K.; PIRES, S. Outsourcing in the automotive industry: from JIT to modular consortia. European Management Journal, v. 15, n. 5, oct. 1997.

[16]. CONTRAN - no 21013 de novembro. 2006.

[17]. ÇENGEL, Y. A.; BOLES, M. A. - Refrigeração e congelação de alimentos. Lisboa: McGrawHill,2001.

[18]. EMBRAPA - Empresa Brasileira de Pesquisa Agropecuária. Disponível em: <http://ainfo.cnptia.embrapa.br/digital/bitstream/item/34409/1/2000-D0C-0042.pdf>. $<$ Acesso em 20 de novembro de 2020.>

[19]. FERNANDES, Cláudio Socorro Caetano. A Logística na Cadeia de Frio em Portugal: Transporte de Produtos Perecíveis Congelados. 2015. 144 f. Tese (Doutorado) - Curso de 
Engenharia Mecânica, Instituto Superior de Engenharia de Lisboa, Lisboa, 2015. Cap. 2. Disponível em: https://core.ac.uk/download/pdf/47134765.pdf. <Acesso em: 21 out. 2020.>

[20]. FLEURY, Paulo Fernando. Supply Chain Management: conceitos, oportunidades e desafios de implementação. Coppead. Rio de Janeiro. 2003. JONES, C. Supply chain management: the key issues. BPICS Control, Oct./Nov. 1989.

[21]. FONTELLES, Mauro José , Marilda Garcia Simões, Samantha Hasegawa Farias e Renata Garcia Simões Fontelles. Metodologia da Pesquisa Cientifica: Diretrizes Para Elaboração de um Protocolo de Pesquisa. Revista Paraense de Medicina, 23 (3), 2009.

[22]. GASPAR, Pedro Dinis; PITARMA, Rui A.. Avaliação das Condições de Transporte e Exposição de Produtos Alimentares Perecíveis Conservados EM FRIO. Covilhã, 2003. Disponível em: <https://ubibliorum.ubi.pt/bitstream/10400.6/7297/1/Art_CLME_2003.pdf>. < Acesso em: 20 out. $2020 .>$

[23]. GONÇALVES, Alex Augusto; PASSOS, Marcelo Gonzalez; BIEDRZYCKI, Aline. Percepção do consumidor com relação à embalagem de alimentos: tendências. Estudos Tecnológicos, São Leopoldo, 2008.

[24]. HAAS, R., Dittmer, P., Veigt, M., and Lutjen, M. Reducing food losses and carbon emission by using autonomous control: a simulation study of the intelligent container. International Journal of Production Economics, 2015.

[25]. HANDABAKA, A. R. Gestão logística da distribuição física internacional. 1. ed. São Paulo: Maltese, 1994.

[26]. HEAP, R. D. - Cold chain performance issues now and in the future. Innovative equipment and systems for comfort \& food preservation, 2006

[27]. HEIDMANN, N.; HELLWEGE, N.; PETERS-DROLSHAGEN, D.; PAUL, S.; DANNIES, A.; LANG, W. A low-power wireless UHF/LF sensor network with web-based remote supervision: implementation in the intelligent container. Baltimore: IEEE, 2013.

[28]. INSTITUTO BRASILEIRO DA QUALIDADE E PRODUTIVIDADE. Manual de metodologia de gestão para adensamento de cadeias produtivas. Curitiba, 1999.

[29]. INTERNATIONAL INSTITUTE OF REFRIGERATION - IIR. Recommendations of the IIR on the quick-frozen-foods cold chain: quick-freezer design and construction, cold stores, transport, retail. Paris, 2006

[30]. Jaffee, S. M., and Henson, S. (2005). Agro-food exports from developing countries: The challenges posed by standards. In Aksoy, M. A., Beghin, J. C. (Eds.), Global agricultural trade and developing countries, The World Bank, Washington, pp. 91-114.

[31]. KEEDI, S. Transportes unitização e seguros internacional de carga. São Paulo: Aduaneiras, 2005.

[32]. KANTAR WORLDPANEL - Novas Tendências Aquecem Congelados. 2017. Disponível em: <https://www.kantarworldpanel.com/pt/news/Novas-Tendncias-aquecem-Congelados>. <Acesso em: 24 nov. 2020>

[33]. LAMBERT, Douglas M; STOCK, James R; VALENTINE, José Geraldo. Administração estratégica da logística. São Paulo: Valentine Consultoria, 1998.

[34]. LAMBIN, J. J. Market-Driven Management: Stratetic \& Operational Marketing. London: Macmillan Business, 2002.

[35]. Mena, C., Adenzo-Diaz, B., and Yurt, O. (2011). The causes of food waste in the supplierretailer interface: Evidence from the UK and Spain. Resources, Conservation and Recycling, (55), 648-658. 
[36]. MELLO, Gabriela Carvalho da Silva; JULIÃO, Letícia; TAPETTI, Rafael. Cadeia do Frio: Garantia de vida mais longa e saudável aos hortifrutícolas. Hortifruti Brasil, Piracicaba - São Paulo, 2011.

[37]. MERCANTILA. Guide to food transport: fruit and vegetables. Copenhagen, 1989.

[38]. PEREIRA, D. - Importância da Cadeia de Frio na Segurança Alimentar de Produtos Congelados e Refrigerados. Coimbra: Escola Superior Agrária, 2011.

[39]. PINTO, J. e NEVE, R. Análise de Riscos no Processamento Alimentar. Porto. Publindústria, Edições Técnicas. 2010.

[40]. POIRIER, C. C.; REITER, S. E. Otimizando sua rede de negócios. São Paulo: Futura, 1997.

[41]. RIBEIRO, Marcia Patricia Reis et al. 0 marketing e a embalagem no desenvolvimento do produto "milhitos" elaborado na disciplina de projeto interdisciplinar em ciência e tecnologia de alimentos. In: SIMPOSIO DE ENSINO DE GRADUAÇÃO, 6., 2008, Piracicaba. Anais eletrônicos... Piracicaba: UNIMEP, 2008.

[42]. RODRIGUES, P. R. A. Gestão Estratégica da Armazenagem. 2ª Edição. Aduaneiras, São Paulo, 2007.

[43]. SEBRAE - Tendências Para a Indústria de Congelados. 2020. Disponível em:<https://www.sebrae.com.br/sites/PortalSebrae/ufs/ms/artigos/tendencias-paraindustria-de-congelados,1d4f4b4383642510VgnVCM1000004c00210aRCRD>. <Acesso em: 24 nov. 2020>

[44]. SISTEMA INTEGRADO DE COMÉRCIO EXTERIOR. SISCOMEX, 2020. Comex Stat. Disponível em: <http://comexstat.mdic.gov.br/pt/home>. <Acesso em: 28/08/2020.>

[45]. SOUZA, C. L.G.de. A teoria geral do comércio exterior: aspectos jurídicos e operacionais. Belo Horizonte: Líder, 2003

[46]. SOBRAL, F. H.de A. Técnicas de unitização de cargas em paletes. Disponível em: < http://www.interlogis.com. br >. Acesso em: 16 out. 2020.

[47]. TINGMAN, W.; JIAN, Z.; XIAOSHUAN, Z. Fish product quality evaluation based on temperature monitoring in cold chain. African Journal of Biotechnology, v. 9, n. 37, p. 6146-6151, 2010.

[48]. TRESSLER, D. K. The FREEZING PRESERVATION OF FOODS. WeStPort: AVI, 1968. (V.1)

[49]. WHITE, J. How COLD WAS IT? KNOW THE WhOLE STORY. Food LOGISTICS, 2007. 


\section{Capítulo 10}

Operação no Porto do Açu: Exportação de petróleo

\section{Mário Amorim}

\section{Kauany Silva}

Daniela Carvalho

\section{Matheus Ferreira}

Resumo: Este artigo tem como o objetivo apresentar uma análise da evolução na movimentação e exportações de petróleo no Porto de Açu, sendo este identificado como um porto de capital totalmente privado e com uma geolocalização privilegiada, destacando-se no cenário nacional. Em menos de 5 (cinco) anos do início das atividades portuárias, já figura entre os principais portos na movimentação e exportação do petróleo. Serão realizadas revisões bibliográficas sobre as movimentações de petróleo nos anos de 2018 e 2019, demonstrando por tabelas atualizadas, e, por fim, concluiremos qual foi o crescimento e a eficiência do porto na exportação e no mercado de O\&G (óleo e gás) no Brasil.

Palavras-chave: Petróleo. Exportação. Movimentação. 


\section{INTRODUÇÃO}

A globalização gerou mudanças nas práticas comerciais e econômicas, tanto no cenário nacional quanto internacional, sendo fator preponderante para redefinir a geografia portuária de alguns países. Sirkin; Hemerling e Bhattacharya (2008), afirmam que após este evento, houve a internacionalização do capital, abertura e ampliação dos mercados, ampliação das cadeias logísticas, diversificação dos produtos e o intercâmbio e interdependência das economias nacionais com a criação do bloco econômico BRICS (Brasil, Rússia, Índia, China e África do Sul).

O Brasil historicamente já passou por alguns ciclos com características econômicas semelhantes ao atual momento. De 1890 a 1913, após o colapso das estruturas devido ao êxodo rural e criação das cidades portuárias, a economia brasileira precisou passar por um intenso desenvolvimento, sendo necessário a reestruturação de importantes cadeias logísticas, como a construção de portos e ferrovias para dar vazão aos aumentos de volume na exportação de café, açúcar, carnes, tabaco, entre outras commodities (Monié, 2003). Atualmente, observamos que tais investimentos pelo poder público voltaram a crescer, reestruturando e interligando os modais de transporte de cargas (SOPESP 2020).

Na década de 50, Getúlio Vargas criou a Petrobrás com a visão estratégica de elevar o Brasil no processo de industrialização nacional, visando autossuficiência na produção do Petróleo, haja vista que anteriormente era de apenas 2.700 barris por dia (Piquet, 2011). Atualmente, segundo dados da FIRJAN 2019 (Federação das Indústrias do Estado do Rio de Janeiro), o Brasil bateu recorde na produção de petróleo com 2.731 milhões de barris ao dia. A construção deste Brasil de oportunidades teve início com a edição da Lei do Petróleo em 1997, que trouxe a flexibilização do monopólio da Petrobrás na exploração e produção de petróleo e gás (Lei 9.478/97). Essa legislação alterou a alíquota de cálculo de royalties de $5 \%$ para $10 \%$, trazendo alterações quanto ao preço de referência para o cálculo de Royalties. Esta mudança, aliada à alta no preço do petróleo, ao crescimento da produção nacional e as variações nas taxas de câmbio, geraram um crescimento espetacular das receitas de royalties auferidas, passando de R\$190 milhões em 1997 para $R \$ 5,04$ bilhões em 2004. 0 estado do Rio de Janeiro recebeu $R \$ 1,041$ bilhão, cerca de $64,35 \%$ do total distribuído entre os onze estados contemplados. À União, coube a parcela de R\$ 1,354 bilhão e, aos Municípios pertencentes aos estados contemplados, 0 valor final foi de $\mathrm{R} \$ 1,7$ bilhão. Tão somente aos municípios fluminenses foram destinados a quantia de $\mathrm{R} \$ 1,139$ bilhão (22,58\% do total distribuído no país), valor alto, se comparado às demais arrecadações.

Dessa forma, desde 2016 o Porto do Açu em parceria com a Prumo e a Oiltanking iniciou a operação de transbordo de petróleo. Entende-se por transbordo, a transferência de produtos por meio de mangotes que são mangueiras especialmente fabricadas para o escoamento de líquidos viscosos entre dois navios atracados em área abrigada por quebra mar. Essa operação elimina a necessidade de baldeação intermediária por um tanque de armazenamento do terminal, possibilitando uma operação confiável e segura, com eficiência e redução no custo final para os clientes. Com esse processo, aumenta-se a competitividade do petróleo brasileiro e o Porto do Açu ganha destaque em relação aos demais terminais no Brasil, oferecendo solidez e atraindo as grandes empresa operadoras de petróleo no Brasil (AÇU PETROEO 2020).

No último ano o Porto do Açu firmou contratos para efetuar o transbordo e exportação do petróleo com grandes empresas tais como: Petrobras, Equinor, Petrogal, Total E\&P do 
Brasil e Shell. Com geolocalização estratégica, a cadeia logística do país é impulsionada conectando os principais serviços através do transporte marítimo, aéreo e rodoviário, além de abrigar uma das maiores bases de apoio offshore do mundo. Dessa forma colaborativa e integrada, estabelece fluxos nacionais e internacionais principalmente com a cabotagem, estimulando, assim, potencial crescimento do Brasil no mercado de óleo e gás (FAZENDO NEGÓCIO NO PORTO DO AÇU, 2020).

\section{EMBASAMENTO TEÓRICO}

Cabe destacar que o Brasil vem ampliando sua participação mundial na exportação de petróleo, de acordo com os dados estatísticos da ANP e SECEX (Secretaria de Comércio Exterior). Em 2018, o Brasil exportou cerca de 410 milhões de barris de petróleo. Em contrapartida, no ano de 2019 a exportação subiu para 427.926 .139 de barris, um aumento considerável, reafirmando sua posição de destaque no mundo do petróleo. Possuímos um grande potencial, tanto em mar como em terra, e, se por um lado, no Rio de Janeiro, em águas fluminenses, ainda existem várias áreas a serem exploradas, recentemente foi descoberto no estado de São Paulo, mais precisamente na Bacia de Santos uma enorme quantidade de petróleo na camada pré-sal (ANP/SDP/SIGEP, Junho/2020).

Gráfico 01. Distribuição da Produção de petróleo por bacia

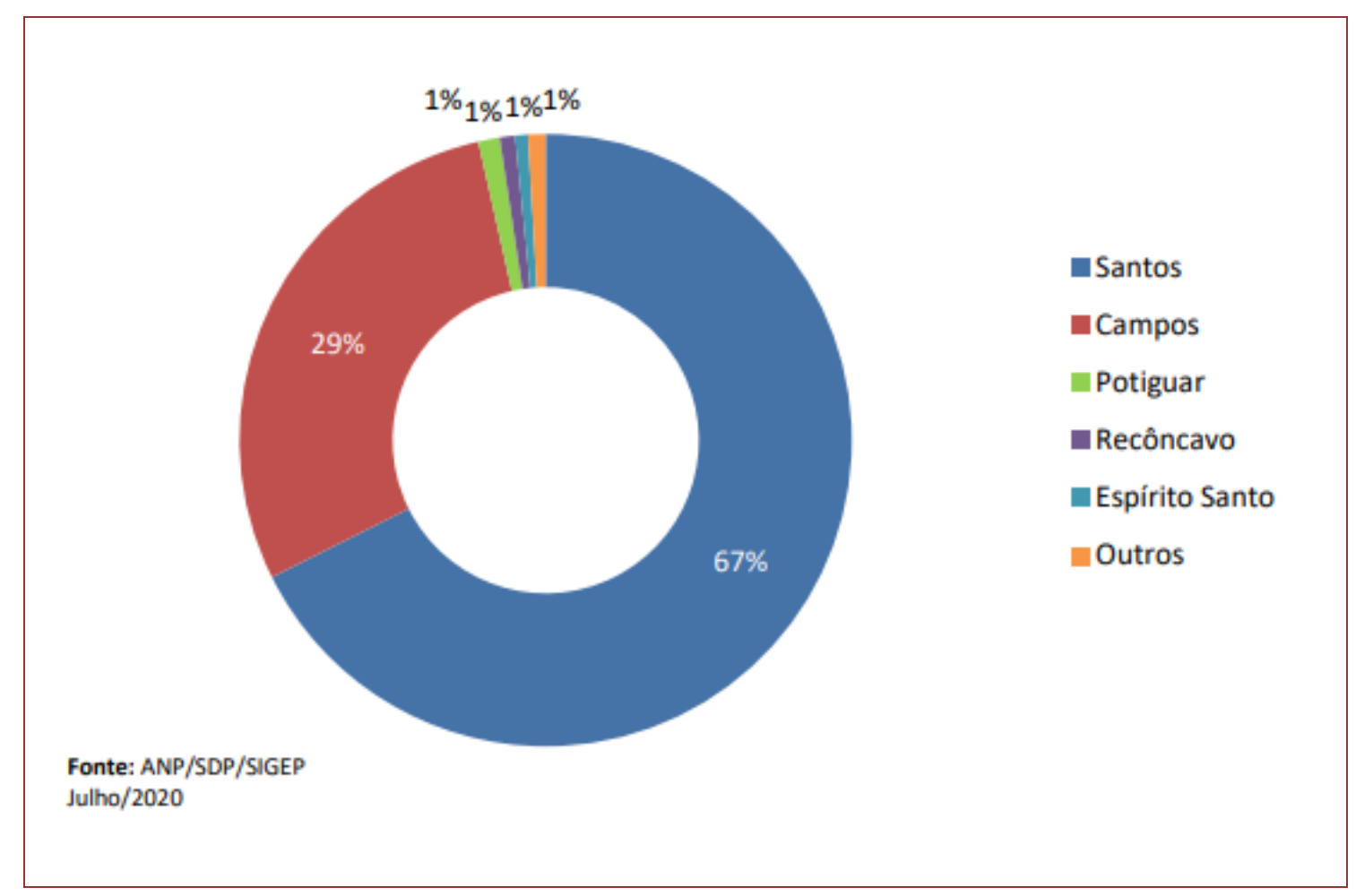

Nos últimos 10 anos, a produção nacional de petróleo aumentou 42\% tornando o Brasil um dos líderes mundiais no setor. 99\% da produção offshore de petróleo e 91\% da produção offshore de gás estão próximas ao Sudeste sendo que o segmento offshore, $60 \%$ do petróleo e $28 \%$ do gás do Brasil são produzidos a uma distância de até $260 \mathrm{~km}$ do Porto do Açu, favorecendo a competividade, reunindo equipamentos, pessoal e logística de insumos para abastecer as cadeias de exploração, produção, refino e 
distribuição de petróleo e gás. Esta redução do custo devida a proximidade da Bacia de Campos faz do complexo porto-indústria a mais competitiva base de apoio para os setores de petróleo, gás e naval (FAZENDO NEGÓCIO NO PORTO DE AÇU, 2020).

Já em relação aos principais projetos de produção de petróleo previstos no Brasil, serão adicionados a extração nacional a capacidade produtiva de 1,2 milhões de barris de petróleo ao dia, quase $50 \%$ da produção atual do país, sendo todos offshore no estado do Rio de Janeiro. A exploração e produção reverbera em diversos sentidos, tanto em relação ao seu efeito multiplicador a montante (em direção a nascente) e a jusante (em direção a foz), quanto em arrecadação para o governo e recursos para o desenvolvimento de soluções tecnológicas (FIRJAM 2019).

Gráfico 02. Distribuição da Produção de petróleo por estado

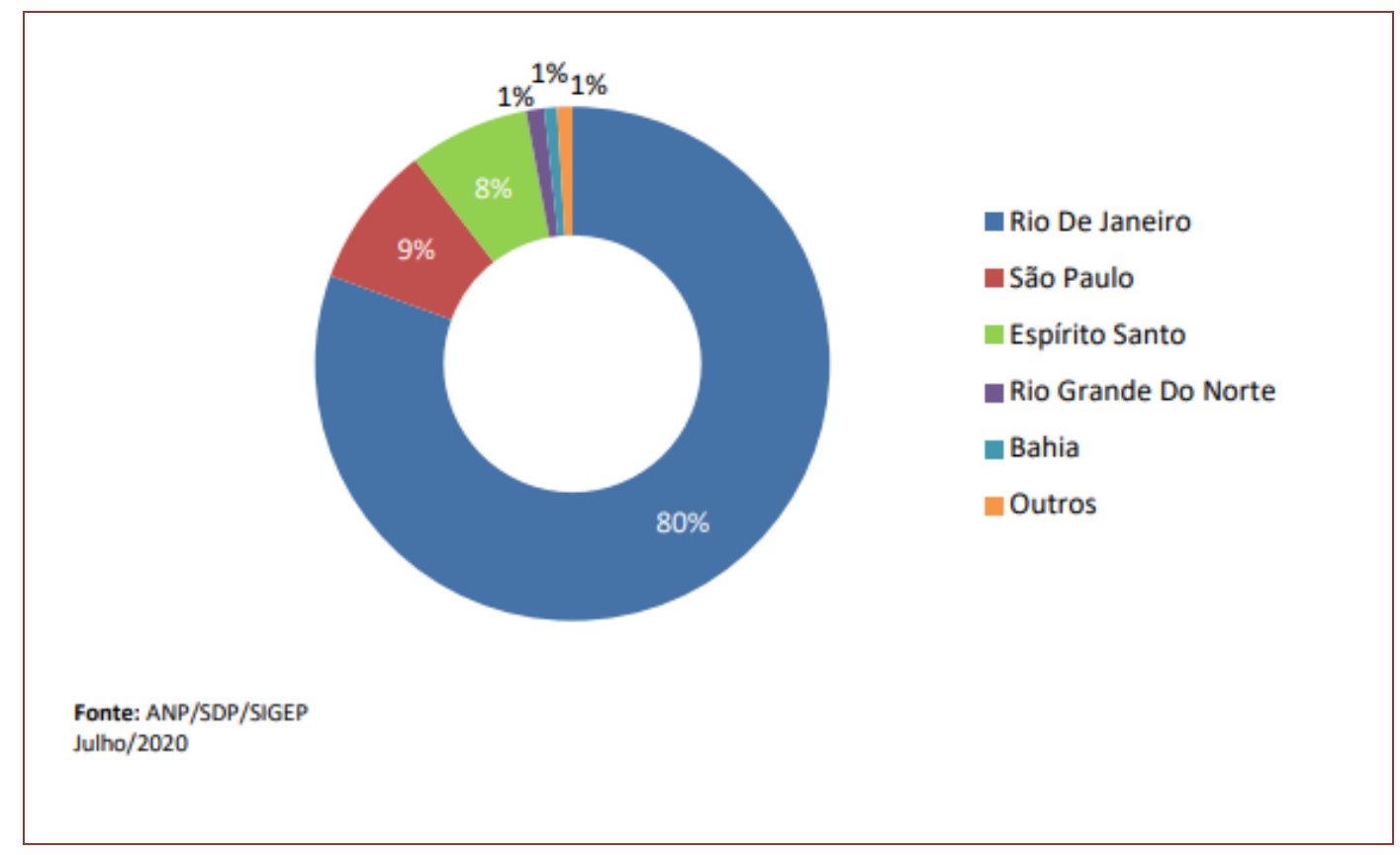

Ao focarmos a região da Bacia de Campos no RJ, temos o município de São João da Barra, localizado ao norte do estado do Rio de Janeiro, prestes a se tornar uma Cidade-porto. A Prumo S.A. (antiga LLX), empresa do grupo EIG Global Energy Partners que atua na área de logística, criada em 2007 é a responsável pelo desenvolvimento do Superporto do Açu e lidera em seu território um GPI (Grande Projeto de Investimento), centralizado por terminal portuário. 0 complexo logístico industrial do Porto do Açu (CLIPA) é um projeto de grande envergadura que difere dos GPIs conduzidos na década de 1970, uma vez que o investimento foi planejado pela iniciativa privada, fora da esfera de um plano estatal de desenvolvimento. Inicialmente, foram previstos investimentos da ordem de US\$ 1,6 bilhões no Terminal Portuário Privativo de Uso Misto do Açu, sendo US\$ 900 milhões alocados pela LLX Minas-Rio, responsável pela implantação do terminal portuário dedicado ao minério de ferro e, US\$ 700 milhões pela LLX Açu, responsável pela operação das demais cargas. 0 projeto completo prevê um terminal de minério de ferro e plantas de peletização, um complexo siderúrgico, usina termoelétricas, indústrias cimenteiras, um polo metal mecânico, unidades petroquímicas, montadora de automóveis, pátios de armazenagem inclusive para gás natural, cluster para processamento de rochas ornamentais e instalações para embarcações de apoio à atividade offshore. Desta forma, o Porto do Açu será um modelo e uma nova concepção 
portuária por procurar a instalação do complexo dinâmico fora de áreas urbanas consolidadas e que possibilite o desenvolvimento das condições gerais de produção, sendo o seu capital de investimentos $100 \%$ privado (FAZENDO NEGÓCIO NO PORTO DO AÇU, 2020).

\section{DESENVOLVIMENTO DA TEMÁTICA}

De acordo com a ANTAQ (Agência Nacional de Transportes Aquaviários) existem mais ou menos 2.000 portos no Brasil de diferentes tamanhos e características. Os mais notáveis são dotados de tecnologias e podem movimentar centenas de toneladas por hora, enquanto outros menores operam apenas pequenas quantidades e em alguns casos, somente um navio por vez. ANTAQ, em seu anuário estatístico de 2019, o Brasil possui um total de 215 instalações portuárias sendo 34 Portos Organizados, 147 Terminais de Uso Privado, 32 Estações de Transbordo de carga e 02 Instalações Portuárias de Turismo que informam toda a movimentação ao SDP (Superintendência de Desenvolvimento e Produção).

O Porto do Açu, maior complexo porto-indústria da América Latina, possui uma linha completa de serviços para a indústria de petróleo e gás do Brasil, tonando-se a maior base de apoio offshore do mundo com 15 berços, desenvolvidos especificamente para atender aos projetos do pré-sal. Possui uma área de $130 \mathrm{~km} 2$, onde $90 \mathrm{~km} 2$ são distribuídos em retro áreas para instalação de indústrias e empresas, contando atualmente com 14 empresa em operação. Os outros $40 \mathrm{~km} 2$, são destinados a maior reserva privada dedicada ao ecossistema de restinga do Brasil, a "RPPN Caruara". Sua instalação do complexo dinâmico foi planejada para estar fora de áreas urbanas consolidadas (FAZENDO NEGÓCIO NO PORTO DO AÇU, 2020).

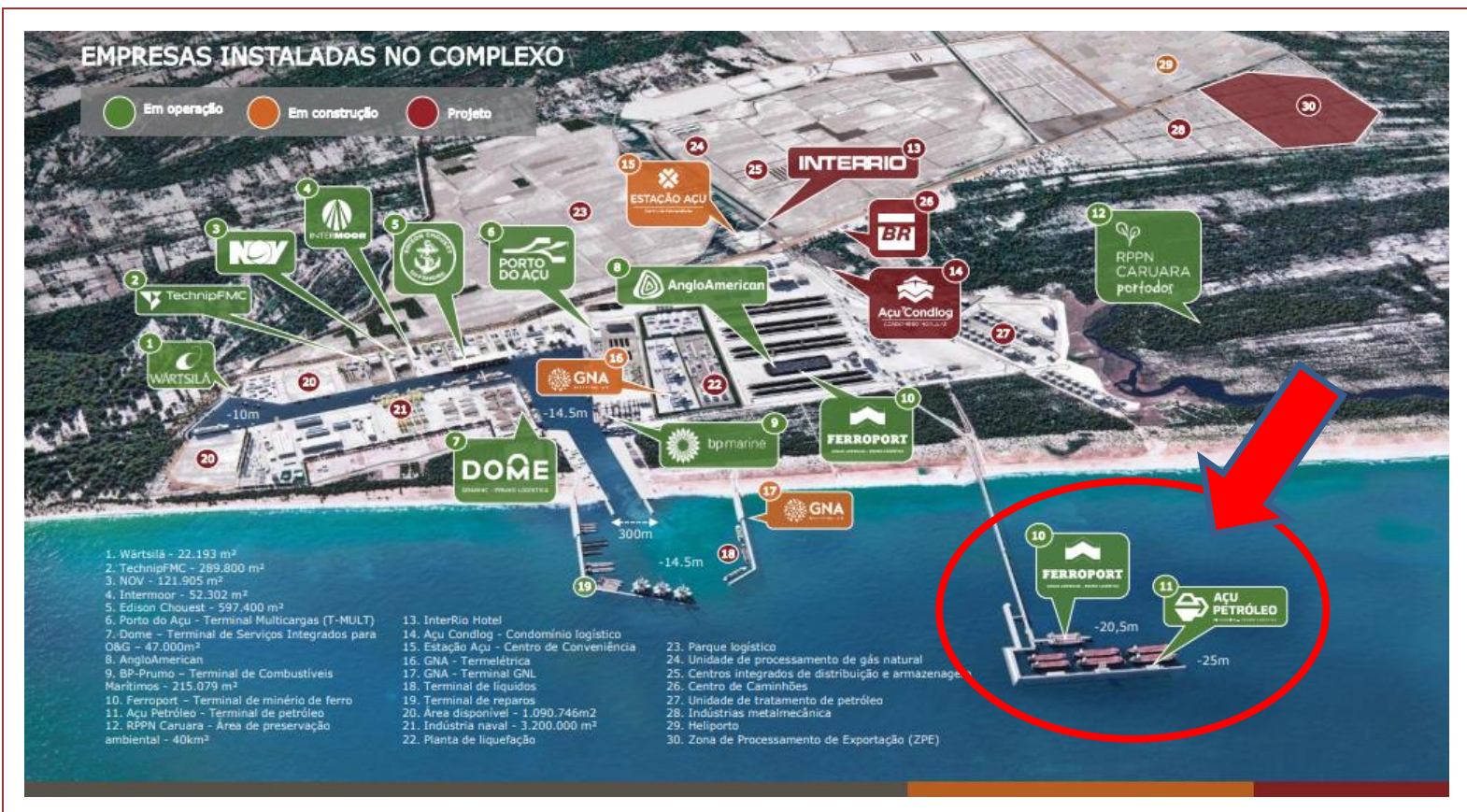

Fonte: Porto do Açu - Empresas Instaladas no Complexo 


\subsection{LOCALIZAÇ̃̃O ESTRATÉGICA}

Localizado no sudeste, a região mais rica, produtiva e populosa do Brasil, o Porto do Açu é um destino global para investimentos, graças ao seu enorme mercado consumidor, recursos naturais abundantes, economia diversificada e enorme potencial de crescimento. Composta por quatro estados - São Paulo, Rio de Janeiro, Minas Gerais e Espírito Santo - responde por cerca de 54\% do PIB nacional e mais de 50\% do comércio exterior do país. A região é uma enorme produtora industrial e do agronegócio e sedia as maiores indústrias latino-americanas de siderurgia, cimento, fertilizantes, produtos químicos e farmacêuticos, bem como indústrias pesadas. O Porto de Açu tem se consolidado como principal polo do setor de óleo e gás do país, transportando cargas e ampliando a prestação de serviços para esse setor. Em entrevista, o CEO da Prumo grupo multinegócios que desenvolve o Porto do Açu, Tadeu Fraga, declarou serem uma plataforma one stop shop onde oferecem diferentes possibilidades de negócios para todos os agentes do setor de O\&G. "Somos origem na fabricação e movimentação de equipamentos e materiais para as operações marítimas, e somos destino do óleo e gás produzidos. Possibilitaremos também o processamento e a transferência do óleo e do gás, além da sua transformação e geração de maior valor agregado como no caso da geração de energia elétrica, o que permite o desenvolvimento de uma cadeia que vai muito além do óleo e gás" (PORTO DO AÇU 2020).

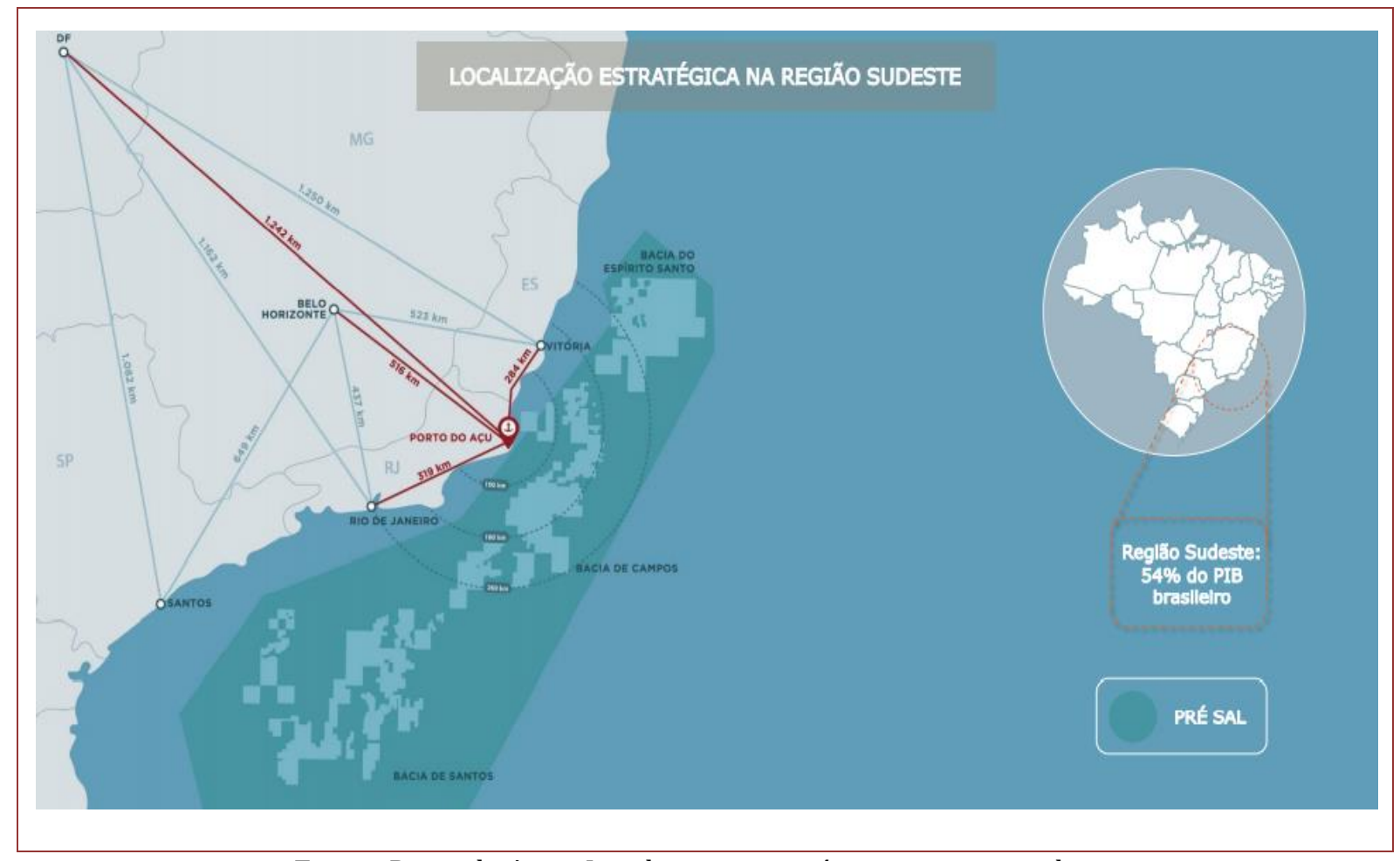

Fonte: Porto do Açu - Localização estratégica na região sudeste 


\section{RESULTADOS E DISCUSSÕES}

O Complexo Logístico Industrial do Porto do Açu (CLIPA) que opera desde 2016 é o único terminal privado do país capaz de operar com navios do tipo VLCC (Very Large Crude Carrier). De 2016 a 2019, já foram exportados aproximadamente 132 milhões de barris de petróleo pelo porto do Açu, sendo que até o ano passado foram realizadas 132 operações das quais 31 foram em navios do tipo VLCC (PORTO DO AÇU - PORTO DE OPORTUNIDADES 2019).

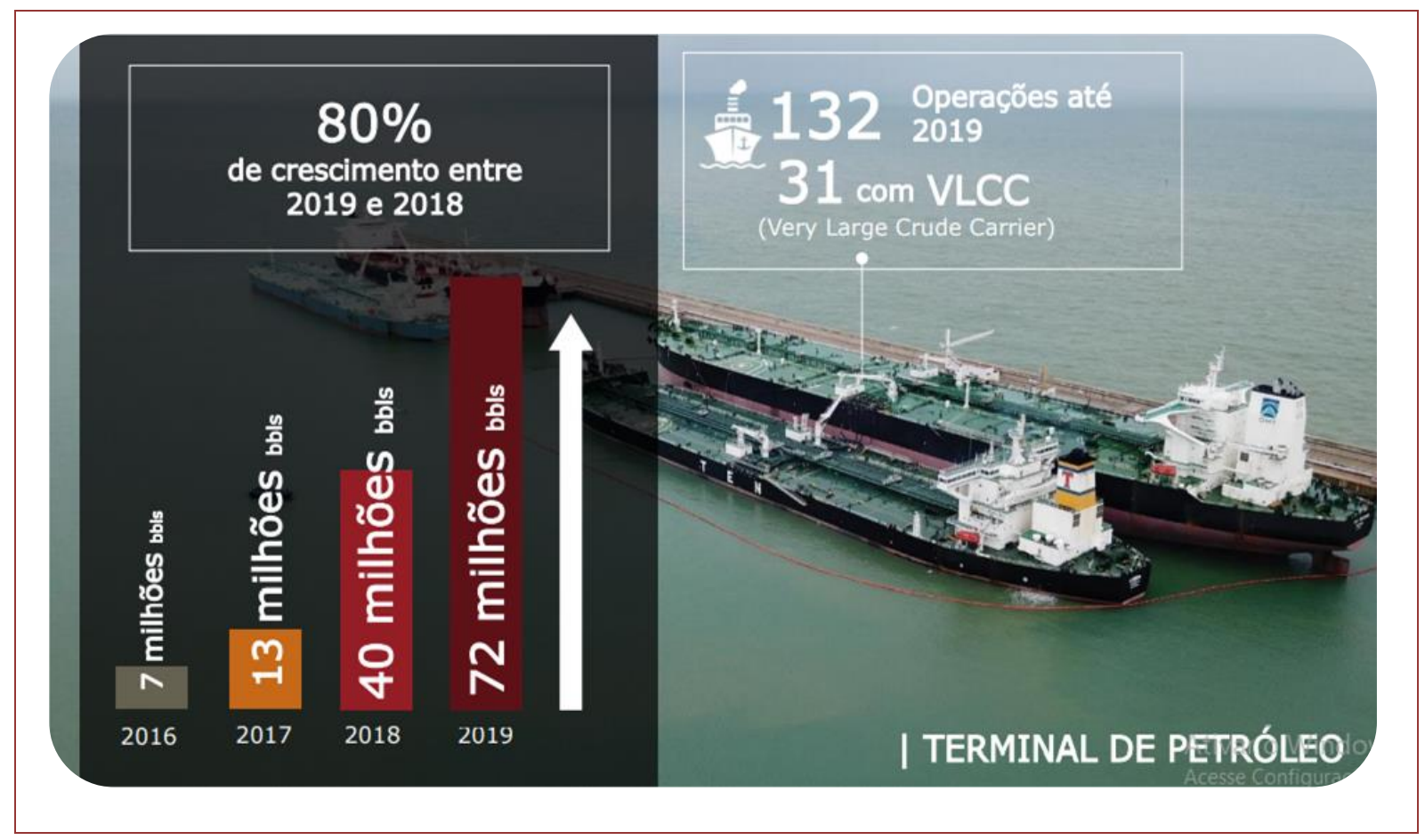

Fonte: Porto do Açu - Crescimento na Exportação

Conforme observado no anuário estatístico brasileiro da ANP 2019, no final de 2018, 792 áreas estavam sob contratos da ANP: 335 blocos na fase de exploração, 84 campos em desenvolvimento da produção e 373 campos na etapa de produção. Se antes a Petrobras era a única contratada em 285 deles, além de ser a operadora do consórcio de outros 13 campos, já em 2018 dos 335 blocos exploratórios sob concessão, a Petrobras tinha participação em 133, dos quais 40 eram concessões exclusivas a essa empresa, e outras 93 em parceria. Destaca-se também os 29 blocos operados pela Petra Energia, sendo 25 em operação exclusiva. A Rosneft operava 13 blocos na Bacia de Solimões, a Parnaíba Gás Natural com 16 blocos na bacia do Parnaíba e a Tog Brasil 10 blocos localizados na Bacia de Alagoas e na Bacia do Recôncavo. Além disso, as seguintes plataformas iniciaram operação no ano de 2018: FPSO Cidade de Campos dos Goytacazes (Campo de Tartaruga Verde e Tartaruga Verde Sudoste); FPSO Petrobras 69 (Campo de Lula); FPSO Petrobras 74; e FPSO Petrobras 75 (Campo de Búzios). Outras empresas que possuem contratos consorciadas ou não entre si e com a Petrobras, são: Alvopetro, Barra Bonita, Barra Energia, Brasoil Manati, BP Energy, Chevron Brasil, CNODC Brasil, CNOOC Petroleum, Dommo Energia, Equinor Brasil, Energizzi Energias, Engepet, Espigão, Geopark Brasil, Guindastes Brasil, Imetame, Karoon, Máxima 07, Newo, Nord, Oeste de Canoas, Oil Group, OP Energia, Orteng Óleo e Gás, Parnaíba Gás Natural, Perícia, Petroborn, Petrogal Brasil, Petroil, Petrol, Petrosynergy, Phoenix, 
Queiroz Galvão, Repsol, Sinopec, Somoil do Brasil, Sonangol Hidrocarbonetos, Sinochen Petróleo, Shell Brasil, Total E\&P do Brasil, Ubuntu Engenharia e Vipetro.

Já em 2019, o terminal do Porto do Açu foi responsável por 15\% das exportações da produção da Petrobras. De acordo com o SOPESP (Sindicato dos Operadores Portuários do Estado de São Paulo) a Petrobras assinou um aditivo no contrato com a Açu Petróleo, em parceria com a Prumo Logística, tendo como finalidade elevar o transbordo de petróleo no seu terminal privado no Porto do Açu, em São João da Barra (Rio de Janeiro). Em abril de 2020, a Petrobras bateu recorde de movimentação de granel líquido, sendo que neste período, 23\% foi exportado pela Açu Petróleo.

Outras empresas também exportam a partir do Porto do Açu e, diante das perspectivas de crescimento das exportações nos próximos anos, a Açu Petróleo prevê a construção de um parque de tancagem e dois oleodutos com $40 \mathrm{Km}$ para conectar o terminal até Barra do Furado, em Quissamã (Rio de Janeiro), e também interligando o Porto do Açu a malha de dutos da Petrobras, possibilitando fornecimento de petróleo cru para as refinarias Regap (Minas Gerais) e Reduc (Rio de Janeiro).

Gráfico 03. Distribuição da produção de petróleo por operador

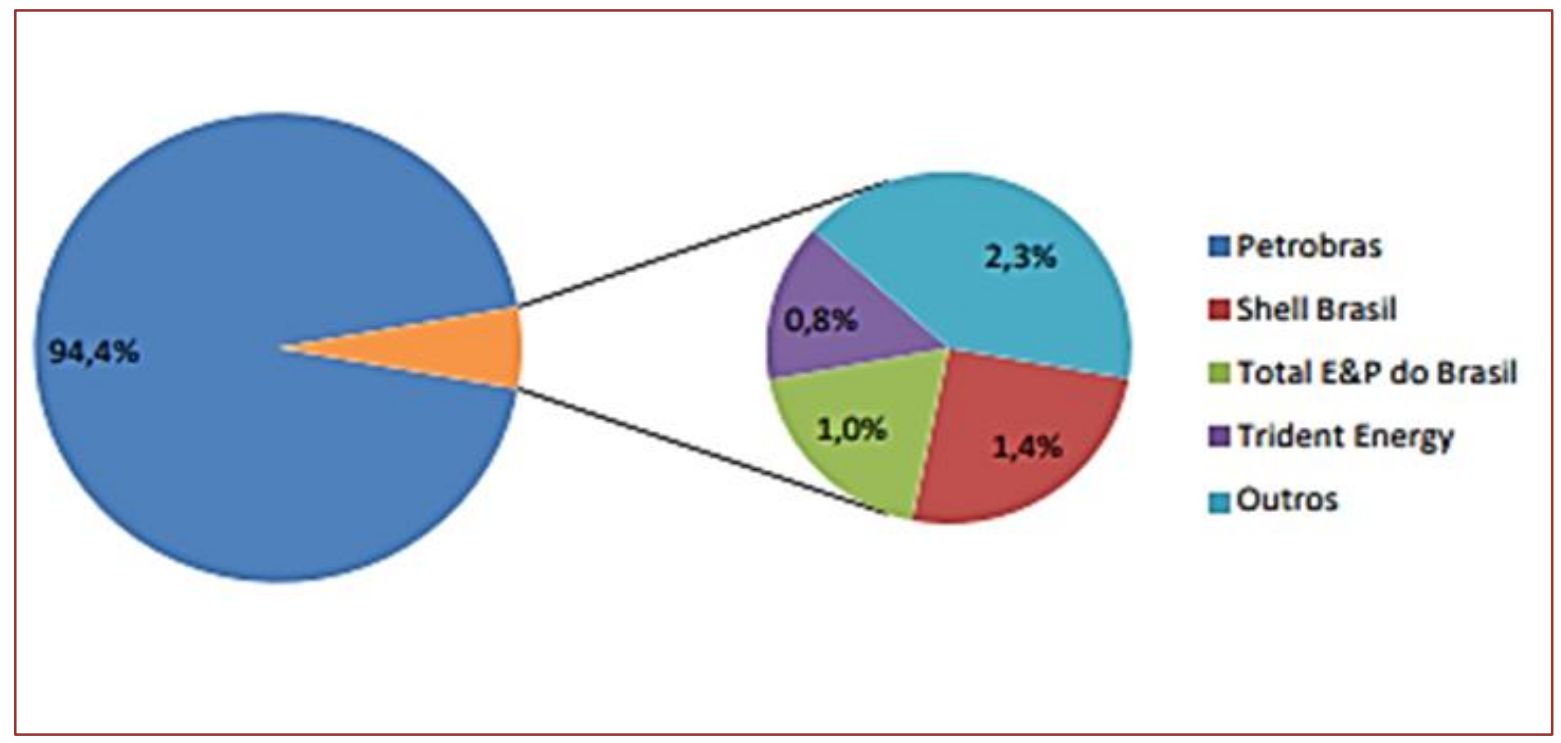

Fonte: ANP/ SDP/ SIGEP Julho 2020

Nota: Considera todos os campos operados pela empresa, independente do percentual de sua participação no contrato

\section{CONSIDERAÇÕES FINAIS}

Após revisão bibliográfica nos órgãos governamentais, intervenientes do setor de petróleo e fontes oficiais do Porto do Açu, onde nosso objetivo foi demonstrar a evolução deste porto na exportação do petróleo pela Petrobras e pelos demais operadores, concluímos que, devido à sua excelente localização, o Porto de Açu poderá atuar no futuro como um hub port na exportação do petróleo, haja vista sua proximidade com as principais bacias marítimas produtoras de petróleo, atuando na cabotagem e na exportação do petróleo produzido no Brasil.

Ainda, podemos concluir que o Porto do Açu é um porto diferenciado de todos os outros portos organizados diretamente ligados ao poder público, uma vez que sua principal operação é com a prestação de serviços offshore e de transbordo, e não simplesmente de 
logística e carga como os demais portos organizados. Ainda que jovem, o Complexo Portuário do Açu possui ousados planos para o desenvolvimento logístico da cadeia portuária.

Sabemos que ainda temos muito que caminhar. Um país continental, com $8 \mathrm{mil} \mathrm{km} \mathrm{de}$ costa e uma vocação exportadora, precisa de pesados investimentos em infraestruturas - estradas, ferrovias, hidrovias e principalmente em portos, para aumentar cada vez mais o seu desempenho. Ao consideramos a Lei 6.830/93 que tratou da modernização dos portos nacionais, autorizando os terminais privados a movimentarem cargas de terceiros, o sistema portuário brasileiro passou a contar com mais 62 terminais de uso privado (TUP). Percebe-se claramente que com o ajuste da lei, obteve-se resultados positivos corroborando o alerta de Oliveira (1996) que afirma que para que aconteça uma renovação do sistema portuário, além de investir em infraestruturas, são necessárias mudanças na regulamentação vigente. E, tanto é verdade, que com os incentivos do governo e principalmente após a Lei 12.815/13 "Marco Regulatório", houve um aumento significativo na quantidade dos TUP's em operação, pois os investidores sentiram-se atraídos a operar em portos organizados. Conforme demonstrado acima pela ANTAQ, atualmente temos um total de 147 TUP's.

Não resta dúvida que o Porto do Açu é, hoje, um exemplo a ser seguido no país em razão da infraestrutura de suas operações, facilitando a cadeia portuária e marítima na movimentação de mercadorias, servindo como uma opção viável de fluxo de entrada e saída de cargas, tanto na esfera regional quanto global.

Com o passar do tempo, serão realizados estudos futuros, nos quais conseguiremos ter uma noção mais exata do desenvolvimento e dos benefícios que este porto trouxe para nosso país, mas desde já, podemos afirmar que somos uma nação enorme com centenas de portos, possuindo alguns deles infraestrutura operacional ineficiente, abrindo, desse jeito, espaço para o desenvolvimento dos atuais portos e implementação de novos terminais privados.

\section{REFERÊNCIAS}

[1]. AÇU PETROLEO - Transbordo de Petróleo 2020. Disponível em: https://acupetroleo.com.br/nosso-negocio/transbordo-de-petroleo. Acesso em 12 set 2020

[2]. ANP. Agência Nacional do Petróleo. Rio de Janeiro: ANP, 2005. Disponível em: http://www.anp.gov.br. Acesso em 13 set 2020

[3]. ANP, Dados Estatísticos. Disponível em: http://www.anp.gov.br/dadosestatisticos. Acesso em 02 set 2020

[4]. ANP, Boletim da Produção de Petróleo e Gás Natural, $n^{\circ}$ 119, Julho 2020. Disponível em: http://www.anp.gov.br/arquivos/publicacoes/boletins-anp/producao/2020-07-boletim.pdf. Acesso em: 1 set 2020

[5]. ANP - Anuário estatístico Brasileiro 2019 pdf. Acesso em 10 set 2020

[6]. ANP Lei do petróleo completa 20 anos. Disponível em:

http://www.anp.gov.br/noticias/3928-lei-do-petroleo-completa-20-anos. Acesso em 02 set 2020

[7]. ANTAQ Anuário Estatístico 2019 pdf. Acesso em 24 ago. 2020

[8]. FAZENDO NEGÓCIO NO PORTO DO AÇU. Disponível em: https://portodoacu.com.br. Acesso em 02 set 2020 
[9]. FIRJAN Anuário da Indústria de Petróleo do Rio de Janeiro - Panorama 2019 pdf.

[10]. LAKATOS, E, M.; MARCONI, M de A - Fundamento da metodologia científica. $6^{a}$ edição 5 a reimpressão. São Paulo, Atlas 2007

[11]. MONIÉ, Frédéric; SILVA, Gerardo (Orgs.). A mobilização produtiva dos territórios. Instituições e logística do desenvolvimento local. Rio de Janeiro, DP\&A, 2003

[12]. OLIVEIRA, Carlos. Modernização dos Portos 2ª edição, São Paulo, 1996

[13]. PIQUET, Roselia. Mar de Riquezas, Terras de Contrastes o Petróleo no Brasil. Rio de Janeiro: Mauad Editora Ltda, 2011

[14]. Porto do Açu - IMPRENSA. Disponível em: https://portodoacu.com.br/porto-do-acu-irareceber-r-165-bilhoes-em-investimentos-nos-proximos-cinco-anos. Acesso em 05 set 2020

[15]. Porto Açu - Documentos. Disponível em: https://portodoacu.com.br/documentos/. Acesso em 26 jul. 2020

[16]. Porto Açu - PORTO DE OPORTUNIDADES 2019 pdf. Acesso em 2 set 2020

[17]. Porto Açu - Um porto de oportunidades para o Brasil. Disponível em: https://www.prumologistica.com.br/wp-Corporativa-Prumo-Agosto-de-2019.pdf. Acesso em 11 set 2020

[18]. PRODANOV, C. Métodos do Trabalho Científico - Métodos e técnicas da pesquisa e do trabalho acadêmico (2 $2^{\text {a }}$ edição) -2013

[19]. SIRKIN, H. L; HERMERLING, J. W; BHATTACHARYA, A. A Globalidade a nova era da globalização: como vencer num mundo em que se corre com todos, por tudo e em toda parte. Rio de Janeiro: Editora Nova Fronteira, 2008, 313p

[20]. SOPESP Notícias. Disponível em: https://www.sopesp.com.br/2020/09/14/a-revolucaosilenciosa-do-transporte-de-cargas-agricolas/. Acesso em 26 ago 2020

[21]. SOPESP Notícias. Disponível em: https://www.sopesp.com.br/2020/06/22/petrobrasvai-dobrar-exportacoes-de-petroleo-a-partir-do-porto-do-acu/. Acessado em 26 ago 2020 


\section{Capítulo 11}

Cargas especiais: As peculiaridades no armazenamento e transporte de cargas perigosas enxofre

Danilo Germano Santos

Raphael Cesar de Brito Aguiar

Resumo: 0 presente artigo tem como objetivo demonstrar todo processo de movimentação do enxofre, desde seu transporte até sua distribuição realizando seu ciclo logístico. Sabemos que o enxofre é considerado uma carga da série perigosa de classe 4 por ser um sólido inflamável e por esse motivo são necessárias diversas medidas como forma de segurança, a fim de evitar possíveis acidentes ambientais que podem ser estendidas a população.

Devido ao grau de perigo do material, é necessário o desenvolvimento de uma infraestrutura adequada para seu recebimento e armazenamento gerando um custo logístico em relação aos demais materiais não considerados da classe de perigo. Entende-se que quando o processo logístico é respeitado e realizado da maneira correta essas ações refletem diretamente na segurança seja ela ambiental e de toda a equipe que possui contato com o material perigoso, poderá afetar na sua qualidade, pois um material bem manuseado e armazenado não gera contaminações e consequentemente não a espalha, reflete em sua produtividade e no lucro do produto, pois um material bem movimentado não perde sua qualidade e consequentemente não perde seu valor agregado.

Contudo ainda há necessidade de investimento no setor de infraestrutura, com a construção de portos e ferrovias para que haja cada vez mais funcionabilidade no transporte, armazenamento e distribuição do material, com o objetivo de evitar o mal uso da estocagem, para não permitir que a mercadoria ultrapasse o tempo limite de sua estocagem assim reduzindo seu tempo de armazenamento e distribuição agregando valor ao produto através de mudanças estratégicas visando sempre a eficiência logística.

Palavras-chave: Enxofre. Transporte. Infraestrutura. 


\section{INTRODUÇÃO}

Segundo o Departamento Nacional de Produção Mineral - DNPM, no Brasil as reservas oficiais para extração de enxofre nativo estão no estado de Sergipe com 3,6 milhões de toneladas, e na Bacia do Paraná com 48 milhões de toneladas (Branco, 2002). Com a ampliação da infraestrutura do Terminal Integrador Portuário Luiz Antônio Mesquita TIPLAM, localizado às margens do Canal de Piaçaguera (no interior do Estuário de Santos), conta com um pátio de capacidade para receber 66 mil toneladas (Figura 1), e um armazém com capacidade de 126 mil toneladas, movimentando cerca de 2,1 milhões de toneladas por ano (Global Fert, 2016).

Figura 1 - Pátio de enxofre

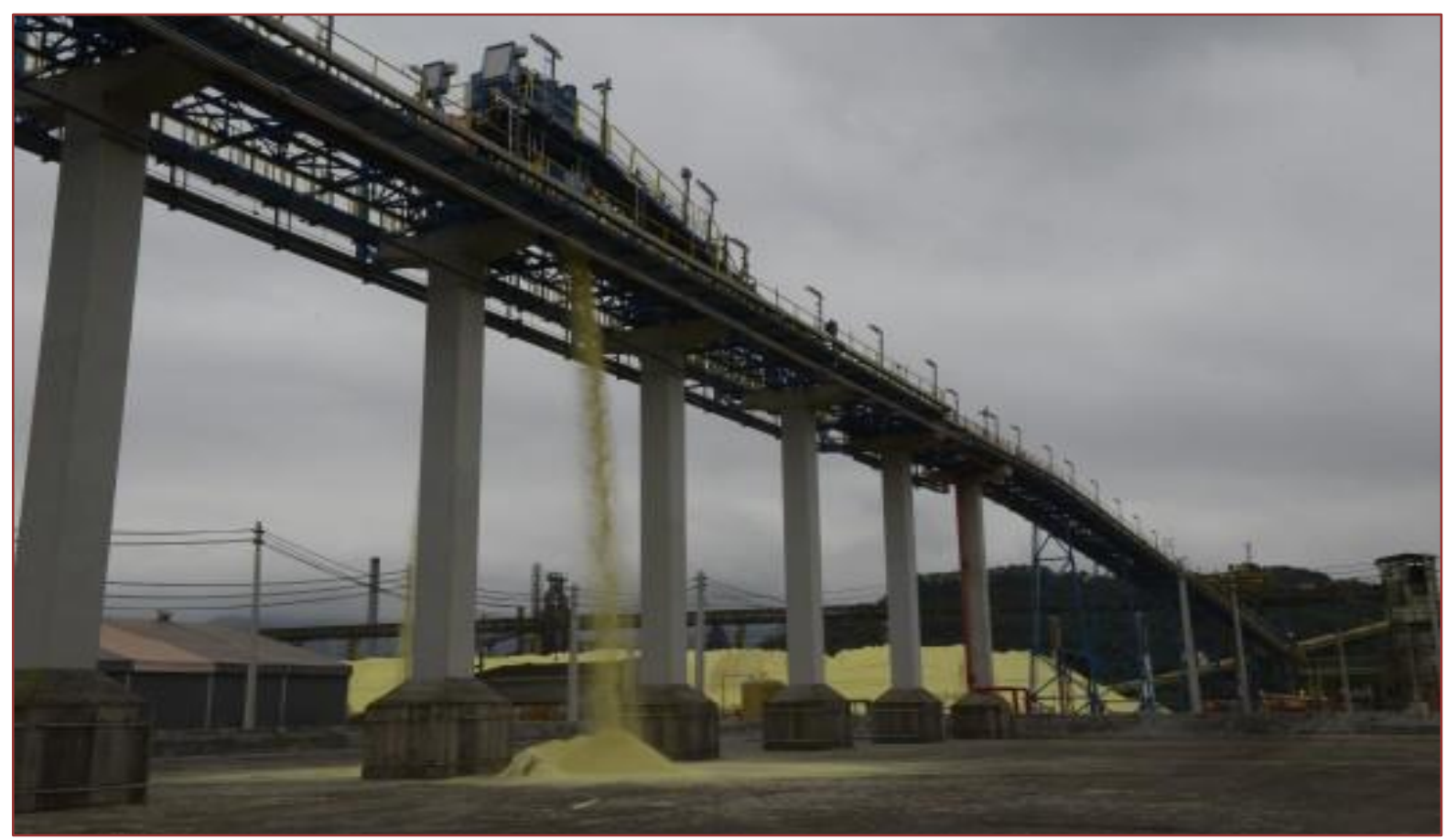

Fonte: Tecnologística (2016)

Essa ampliação do terminal representou um aumento de 4,3\%, na importação do enxofre, no ano de 2018 representou uma alta de 19,6\% em relação aos primeiros dois meses ano anterior (Brasil Caminhoneiro, 2018).

Por ser um tipo de produto que está dentro da classe 4 (Figura 2) de produtos perigosos, sendo um sólido inflamável (que se inflama quando entra em contato com chamas ou até mesmo com o próprio atrito),esse aumento nas movimentações deve ser acompanhado por rigorosas fiscalizações, pois o Enxofre representa sérios riscos no manuseio, às instalações onde são armazenados e ao próprio meio ambiente, portanto dentro do território brasileiro é necessário seguir as normas e regras de segurança, definidos pela Portaria $n^{\circ}$ 204/97 do Ministério dos Transportes os produtos considerados perigosos(MastersulComex,2019), fiscalizados pelas agências regulatórias brasileiras ANTT, ANTAQ e ANAC, que atuam sobre o transporte rodoviário, aquaviário e aeroviário, e estabelece padrões e normas técnicas para transportar esse tipo de carga dentro e fora da área portuária, como: identificação, acondicionamento, embalagem e toda sua documentação. (ANTAQ, ANTT, 2020). 


\section{CLASSE 4 - SÓLIDOS INFLAMÁVEIS, SUBSTÂNCIAS SUJEITAS À COMBUSTÃO ESPONTÂNEA, SUBSTÂNCIAS QUE, EM CONTATO COM A ÁGUA EMITEM GASES INFLAMÁVEIS.}

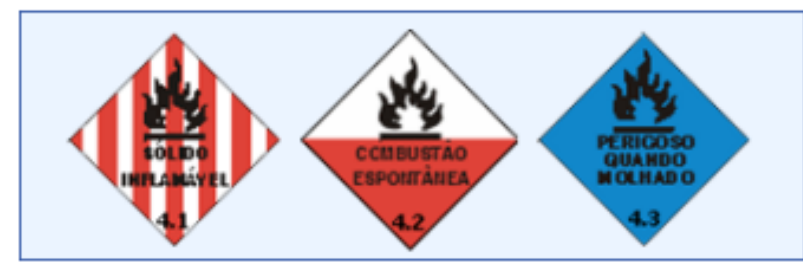

4.1 - Sólidos sujeitos a combustão imediata e sólidos que podem causar ignição mediante fricção; auto-reativos (sólidos e líquidos) e substâncias relacionadas; explosivos neutralizados (reação exotérmica).

4.2 - Substâncias sujeitas à combustão espontânea.

4.3 - Substâncias que, em contato com a água, emitem gases inflamáveis.

Fonte: Práticas de Operações Portuárias

Após a repercussão internacional sobre a explosão em agosto de 2020 de uma área do porto em Beirute no Líbano, causada pelo armazenamento, (não se sabe em que condições de armazenamento) de Nitrato de Amônio, o assunto trouxe à tona a preocupação de como produtos perigosos que são usados na fabricação de fertilizantes, herbicidas, inseticidas e explosivos (CETESB), são manuseados, transportados e acondicionados ao redor do mundo, e como isso é feito no Brasil.

Segundo documentos obtidos pela CNN, a substância estava abandonada desde 2013 no porto de Beirute, e o diretor da alfândega Libanesa Badri Daher e outros funcionários alertaram por anos e solicitaram as autoridades para que fosse retirada a substância do porto devido ao alto risco, mas não obtiveram êxito no pedido devido à grande burocracia. (CNN BRASIL, 2020).

Como são produtos que reagem com o meio onde estão armazenados, é de extrema importância para os terminais que manuseiam essas classes de produtos perigosos seguirem as orientações e normas técnicas de segurança das agencias fiscalizadoras brasileiras. (Oswaldo Cruz, 2003).

0 presente artigo tem como objetivo geral realizar um estudo sobre cargas especiais, direcionado ao transporte de cargas perigosas com ênfase no transporte de enxofre. A fim de compreender a infraestrutura realizada para transportar e armazenar o material sem que ocorram danos ao meio ambiente e a população. Como objetivo específico, estudar os impactos e etapas logísticas do transporte de enxofre, a fim de entender o processo de movimentação, armazenagem e custo logístico gerado em torno desse material. 
Segundo Prodanov; Freitas (2013), o estudo trata-se de uma revisão bibliográfica, análise qualitativo-explicativa e quantitativo-explicativa. Segundo o Departamento Nacional de Produção Mineral - BRANCO (2020), a pesquisa qualitativo-explicativa, visa explorar, fornecer informações, elaborar hipóteses e aprimorar ideias, enquanto a quantitativo-explicativa define modelos, conecta ideias e identifica a ocorrência de causas e efeitos.

Através da realização de pesquisas, permitiu-se analisar aspectos que influenciam diretamente a vida do trabalhador que atua e faz parte desse processo logístico, do meio ambiente e até mesmo da população. Todas as etapas (identificação, acondicionamento, embalagem e toda sua documentação) de uma devida carga perigosa devem ser analisadas e fiscalizadas de forma rigorosa devido a todos os riscos que devida substância ou material apresenta, desta forma a pesquisa visa estudar os impactos e etapas logísticas do transporte de enxofre, a fim de entender o processo de movimentação, armazenagem e custo logístico gerado em torno desse material.

\section{FUNDAMENTAÇÃO TEÓRICA}

A Cadeia de Suprimentos como é conhecida no Brasil, ou Suplly Chain nos termos internacionais, é um sistema que pode ser determinante para o sucesso ou não de pequenas ou grandes empresas. De acordo com Ballou (2006), há incontáveis razões para a importância da cadeia logística. É importante estudar essas razões, pois a cadeia de suprimentos agrega valor ao cliente e se perde quando o produto não está ao alcance dos consumidores no local e nem no tempo adequado.

Um exemplo da agregação de valor do produto está na disposição do consumidor em pagar por um produto ou serviço, o valor a mais do que foi o custo de ser colocada à sua disposição. Gerenciar essa estrutura requer planejamento para que haja eficiência, e isso é um grande desafio para as organizações. E deve-se entender a complexidade desse sistema, pois estão envolvidos vários membros dessa estrutura como: fornecedores, representantes, provedores de serviço terceirizados e intermediários em geral (MEUSUCESSO.COM, 2014).

Para Barat (2007), países como Inglaterra e EUA, que investiram na construção de ferrovias e portos e em sua operação, sua eficiência no transporte de produtos que eram destinados a indústria aumentou e isso fez com que os custos de insumos industriais diminuíssem e absorvessem bens de capital e tecnologia.

De acordo com Russo (2009), a armazenagem representa entre 10 e $40 \%$ do custo logístico e tem um papel essencial no processo, pois a armazenagem não agrega valor ao produto, e a busca por aperfeiçoar os espaços para armazenar a carga é fundamental buscando diminuir os custos com a estocagem, pois o excesso de estoque é acúmulo de materiais, e seu controle é de importância vital em parâmetros econômicos. Reduzir o tempo entre compra e entrega é um dos maiores desafios das organizações, exigindo sempre mudanças nas estratégias, por isso se faz necessário uma boa distribuição dos materiais ou produtos até os pontos de venda ou consumidor final.

Tanto o transporte como a manutenção de estoques representam dois terços dos custos totais, o transporte agregando valor de local ao produto, pois, para haver movimentação das matérias primas é necessário que exista o transporte atendendo aos mercados para que o produto não se deteriore ficando retidos nos canais logísticos. A manutenção dos estoques agrega valor ao tempo, pois os estoques servem como "pulmões" garantindo aos clientes disponibilidade dos produtos em maior demanda e normalmente é 
impossível e impraticável produzir instantaneamente, buscando metodologias mais eficientes produzindo e distribuindo suas mercadorias. Para fechar essas atividades primárias o processamento de pedidos tem um custo menor comparado aos dois primeiros, mas não deixa de ser importante na determinação dos prazos da entrega dos pedidos ao cliente, pois desencadeia toda a movimentação entre produto e a entrega (BALLOU, 2006).

Uma forma de acelerar esse processo nas atividades primarias e distribuir melhor suas mercadorias foi a unitização de cargas, e segundo Keedi (2004 apud SILVEIRA, 2010), a unitização de carga é uma forma mais fácil de movimentar seus produtos agregando pequenas quantidades de carga dentro de um recipiente de maior volume, armazenando de forma mais simplificada, ganhando agilidade na hora de levar seu produto que pode ser entregue na porta do cliente, armazenado e seguro dentro de um único recipiente. Os portos e terminais de carga tiveram que se adequar a esse novo padrão, e isso fez com que os resultados fossem satisfatórios, pois as máquinas e equipamentos para o transporte de carga evoluíram e se padronizaram, reduzindo custos e tempo, pois se manipula menos volumes de carga, mão de obra reduzida e menor tempo de operação em embarque e desembarque.

Porém ainda existem algumas desvantagens como citam Franceschini; Gurgel (2002 apud OLIVEIRA, 2010), destacando a exigências de equipamentos específicos para movimentar e armazenar esses recipientes, dificuldades para inspecionar, certo aumento de custos com a devolução dos recipientes e a limitação de volumes por modais que transportam esses recipientes.

Há exceções no transporte de carga que dificultam a movimentação e armazenagem desses produtos, que ultrapassam as características padrões e não podem ser unitizadas em recipientes comuns ao transporte de cargas, como é o caso de cargas que excedem as dimensões físicas e o peso. Cargas com 150 toneladas ou acima que necessitam de equipamentos especiais para o transporte e movimentação, o que requer regras especiais para o transporte em vias públicas, como acontece na maioria dos países, pois possuem leis que restringem a largura, altura e comprimento da carga a ser transportada. (SCHOELER, 2000).

E esse tipo é caracterizado principalmente por serem frágeis, com uma perecibilidade alta, dificultam o armazenamento, demandam de certos cuidados, fogem dos padrões normais de unitização e transporte, e são denominadas cargas especiais, e não está dentro dos padrões estabelecidos pela resolução no 211 de 13/11/2006 / CONTRAN conselho nacional de trânsito, pois necessitam de veículos e autorizações especiais para ser transportadas. (CONTRAN - CONSELHO NACIONAL DE TRÂNSITO, 2006).

As cargas chamadas de especiais requerem certos cuidados durante seu transporte, armazenamento e distribuição como é o caso das cargas com excesso de peso, excesso nas dimensões (SCHOELER, 2000), e cargas perigosas como as cargas explosivas e produtos químicos, segundo a classificação da ONU para o risco de produtos perigosos (Tabela 1),a Comissão Econômica das Nações Unidas para a Europa (UNECE, 2017), e que tem que seguir normas e orientações do órgão regulador no Brasil para importação, exportação, comércio e tráfego para esse tipo de cargas e produtos, que é o Ministério da Defesa através do Exército Brasileiro pelo decreto $\mathrm{n}^{\circ} \mathbf{1 0 . 0 3 0}$, de 30 de setembro de 2019.(BRASIL, 2019). 
Tabela 1 - Classificação ONU dos Riscos dos Produtos perigosos

\begin{tabular}{|c|c|c|}
\hline Classificação & Subclasse & Definições \\
\hline \multirow{6}{*}{$\begin{array}{l}\text { Classe } 1 \\
\text { Explosivos }\end{array}$} & 1.1 & Substância e artigos com risco de explosão em massa. \\
\hline & 1.2 & Substância e artigos com risco de projeção, mas sem risco de explosão em massa. \\
\hline & 1.3 & $\begin{array}{l}\text { Substâncias e artigos com risco de fogo e com pequeno risco de explosão ou de } \\
\text { projeção, ou ambos, mas sem risco de explosão em massa. }\end{array}$ \\
\hline & 1.4 & Substância e artigos que não apresentam risco significativo. \\
\hline & 1.5 & Substâncias muito insensíveis, com risco de explosão em massa; \\
\hline & 1.6 & Artigos extremamente insensíveis, sem risco de explosão em massa. \\
\hline \multirow{3}{*}{$\begin{array}{l}\text { Classe } 2 \\
\text { Gases }\end{array}$} & 2.1 & $\begin{array}{l}\text { Gases inflamáveis: são gases que a } 20^{\circ} \mathrm{C} \text { e à pressão normal são inflamáveis } \\
\text { quando em mistura de } 13 \% \text { ou menos, em volume, com o ar ou que apresentem } \\
\text { faixa de inflamabilidade com o ar de, no mínimo } 12 \% \text {, independente do limite } \\
\text { inferior de inflamabilidade. }\end{array}$ \\
\hline & 2.2 & $\begin{array}{l}\text { Gases não-inflamáveis, não tóxicos: são gases asfixiantes, oxidantes ou que não se } \\
\text { enquadrem em outra subclasse. }\end{array}$ \\
\hline & 2.3 & $\begin{array}{l}\text { Gases tóxicos: são gases, reconhecidamente ou supostamente, tóxicos e corrosivos } \\
\text { que constituam risco à saúde das pessoas. }\end{array}$ \\
\hline $\begin{array}{c}\text { Classe } 3 \\
\text { Líquidos Inflamáveis }\end{array}$ & - & $\begin{array}{l}\text { Líquidos inflamáveis: são líquidos, misturas de líquidos ou líquidos que contenham } \\
\text { sólidos em solução ou suspensão, que produzam vapor inflamável a temperaturas } \\
\text { de até } 60,5^{\circ} \mathrm{C} \text {, em ensaio de vaso fechado, ou até } 65,6 \text { o } \mathrm{C} \text {, em ensaio de vaso aberto, } \\
\text { ou ainda os explosivos líquidos insensibilizados dissolvidos ou suspensos em água } \\
\text { ou outras substâncias líquidas. }\end{array}$ \\
\hline \multirow{3}{*}{$\begin{array}{c}\text { Classe } 4 \\
\text { Sólidos Inflamáveis; } \\
\text { Substâncias sujeitas } \\
\text { à combustão } \\
\text { espontânea; } \\
\text { substâncias que, em } \\
\text { contato com água, } \\
\text { emitem gases } \\
\text { inflamáveis }\end{array}$} & 4.1 & $\begin{array}{l}\text { Sólidos inflamáveis, substâncias auto-reagentes e explosivos sólidos } \\
\text { insensibilizados: sólidos que, em condições de transporte, sejam facilmente } \\
\text { combustíveis, ou que por atrito possam causar fogo ou contribuir para tal; } \\
\text { substâncias auto-reagentes que possam sofrer reação fortemente exotérmica; } \\
\text { explosivos sólidos insensibilizados que possam explodir se não estiverem } \\
\text { suficientemente diluídos. }\end{array}$ \\
\hline & 4.2 & $\begin{array}{l}\text { Substâncias sujeitas à combustão espontânea: substâncias sujeitas a aquecimento } \\
\text { espontâneo em condições normais de transporte, ou a aquecimento em contato } \\
\text { com ar, podendo inflamar-se. }\end{array}$ \\
\hline & 4.3 & $\begin{array}{l}\text { Substâncias que, em contato com água, emitem gases inflamáveis: substâncias que, } \\
\text { por interação com água, podem tornar-se espontaneamente inflamáveis ou liberar } \\
\text { gases inflamáveis em quantidades perigosas. }\end{array}$ \\
\hline \begin{tabular}{c|} 
Classe 5 \\
Substâncias \\
Oxidantes e \\
Peróxidos Orgânicos
\end{tabular} & 5.1 & $\begin{array}{l}\text { Substâncias oxidantes: são substâncias que podem, em geral pela liberação de } \\
\text { oxigênio, causar a combustão de outros materiais ou contribuir para isso. }\end{array}$ \\
\hline \begin{tabular}{c|} 
Classe 5 \\
Substâncias \\
Oxidantes e \\
Peróxidos Orgânicos
\end{tabular} & 5.2 & $\begin{array}{l}\text { Peróxidos orgânicos: são poderosos agentes oxidantes, considerados como } \\
\text { derivados do peróxido de hidrogênio, termicamente instáveis que podem sofrer } \\
\text { decomposição exotérmica auto-acelerável. }\end{array}$ \\
\hline \multirow{2}{*}{$\begin{array}{l}\text { Classe } 6 \\
\text { Substâncias Tóxicas } \\
\text { e Substâncias } \\
\text { Infectantes }\end{array}$} & 6.1 & $\begin{array}{l}\text { Substâncias tóxicas: são substâncias capazes de provocar morte, lesões graves ou } \\
\text { danos à saúde humana, se ingeridas ou inaladas, ou se entrarem em contato com a } \\
\text { pele. }\end{array}$ \\
\hline & 6.2 & $\begin{array}{l}\text { Substâncias infectantes: são substâncias que contém ou possam conter patógenos } \\
\text { capazes de provocar doenças infecciosas em seres humanos ou em animais. }\end{array}$ \\
\hline $\begin{array}{l}\text { Classe } 7 \\
\text { Material radioativo }\end{array}$ & - & $\begin{array}{l}\text { Qualquer material ou substância que contenha radionuclídeos, cuja concentração } \\
\text { de atividade e atividade total na expedição (radiação), excedam os valores } \\
\text { especificados. }\end{array}$ \\
\hline $\begin{array}{l}\text { Classe } 8 \\
\text { Substâncias } \\
\text { corrosivas }\end{array}$ & - & $\begin{array}{l}\text { São substâncias que, por ação química, causam severos danos quando em contato } \\
\text { com tecidos vivos ou, em caso de vazamento, danificam ou mesmo destroem } \\
\text { outras cargas ou o próprio veículo. }\end{array}$ \\
\hline $\begin{array}{c}\text { Classe } 9 \\
\text { Substâncias e Artigos } \\
\text { Perigosos Diversos }\end{array}$ & - & $\begin{array}{l}\text { São aqueles que apresentam, durante o transporte, um risco não abrangido por } \\
\text { nenhuma das outras classes. }\end{array}$ \\
\hline
\end{tabular}


Ainda de acordo com o Ministério da Defesa, o transporte, armazenagem e distribuição desses materiais devem seguir algumas regras como: compartimentos de segurança revestidos com blindagem de chapa de aço (com espessura mínima de 4,8 mm, em aço do American Iron and Steel Institute - AISI 1020), devem estar na carroceria com fácil acesso, ter sua inviolabilidade preservada e podem ser passivos de escolta.

$\mathrm{Na}$ armazenagem os depósitos deverão ter monitoramento eletrônico permanente, os depósitos deverão estar com distâncias mínimas de segurança em relação a rodovias, ferrovias, edifícios habitados, outros depósitos e ferrovias. Para determinar a capacidade de armazenamento nestes depósitos deverão se levar em consideração alguns fatores como: dimensões das embalagens, serem acondicionado em material de baixa resistência (vidro, plástico, cerâmica etc.), altura máxima de equipamentos, entre outros.

Na distribuição e circulação de tráfego, os materiais explosivos e químicos deverão em todo território brasileiro estar acompanhado das guias de tráfego que corresponde aos produtos em todo Brasil durante seu percurso, e devem ser anexadas as guias de tráfego o termo de transferência de posse que devem constar a origem e destino que deve ser assinado pelo fornecedor e pelo adquirente dos produtos e devem ser acompanhas em todo percurso até seu destino. Também devem estar seguras contra desvios, roubos e furtos, proteção de patrimônio e cidadãos. (BRASIL, 2019).

Destacando para a nossa região e o objeto da pesquisa, o nitrato de amônio e o enxofre que são movimentados na área portuária de Santos, são substancias usadas em herbicidas, inseticidas, fertilizantes e na produção de explosivos, e requerem uma atenção especial no seu manuseio e movimentação, quanto pelo seu grau de risco, essas substancias necessitam de controle e fiscalização, pois são produtos químicos que se enquadram em cargas especiais, pelo seu transporte e armazenagem que fogem dos padrões de cargas comuns por suas reações que podem causar incêndio espontâneo e explosão, dependendo das condições em que são armazenados e manuseados, pois o Exército Brasileiro deve acompanhar o transporte e armazenamento, afirma o presidente da OAB Santos, Rodrigo Julião (DIARIO DO LITORAL, 2020).

Esses produtos se destacam pela grande movimentação nos terminais da baixada santista, sendo um deles o Terminal Integrador Portuário Luiz Antônio Mesquita TIPLAM (Figura 2), que no ano de 2019 acumulou uma movimentação de 667.756 toneladas de adubo (nitrato de amônio usado como fertilizante), e 1.375,768 toneladas de enxofre descarregadas no terminal, tendo seu principal país fornecedor a Rússia com 660.892 toneladas, e ainda conta com outros países exportadores importantes como Estados Unidos, Emirados Árabes e Canadá. (ANTAQ, 2020). 
Figura 2 - TIPLAM Terminal Santos / SP

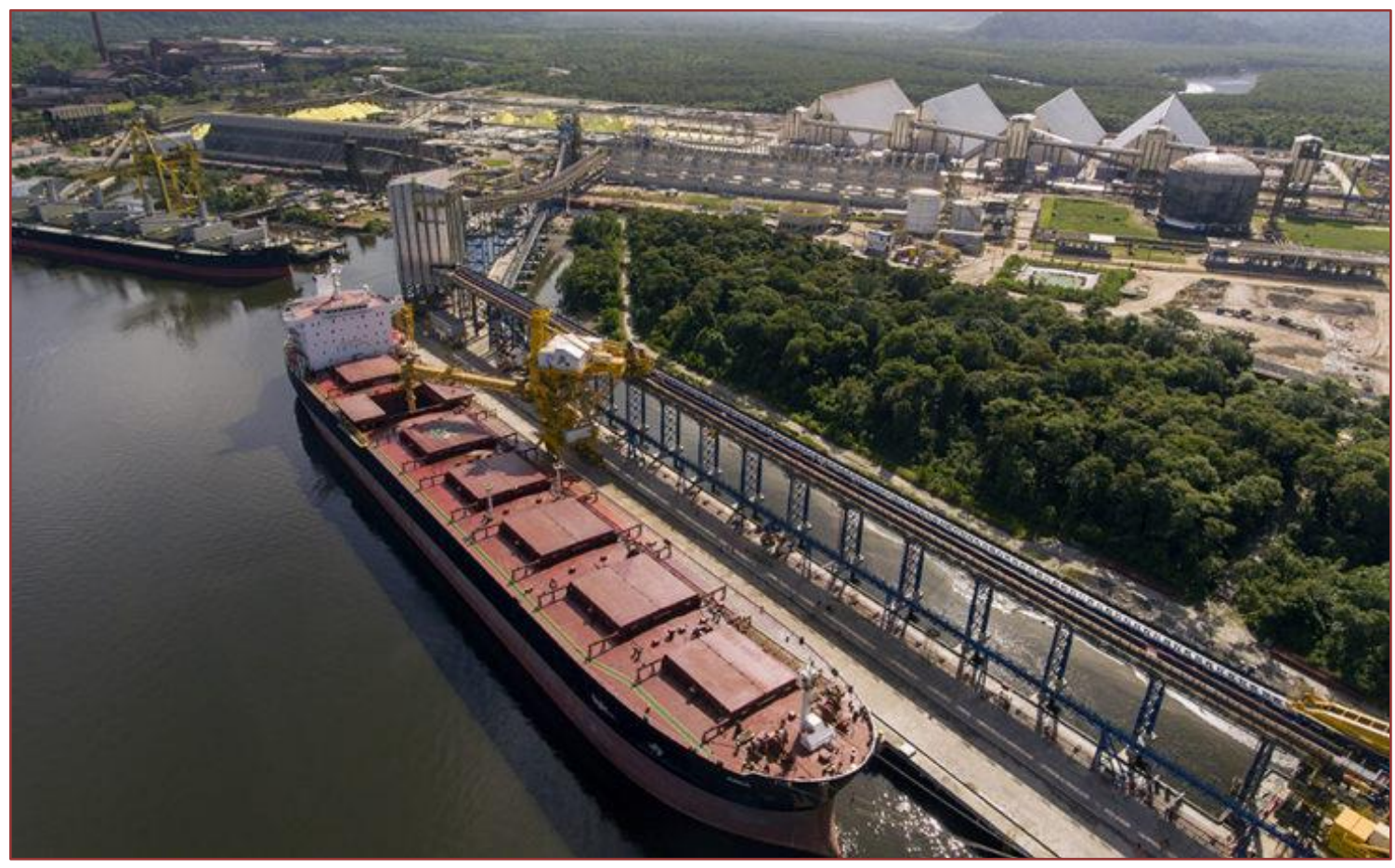

Fonte: VLI - Logística

\section{DESENVOLVIMENTO DA TEMÁTICA}

A logística de transporte é designada para direcionar o modal seja ele de origem ferroviária, aeroviária, aquaviário ou rodoviária, de forma adequada a fim de transportar uma determinada mercadoria, de acordo com o seu volume, segurança, custos e tempo. Sabemos a importância de se desenvolver um bom planejamento logístico para que haja controle no processo de importação e exportação com segurança e qualidade em sua infraestrutura.

Os custos logísticos são todos os custos relacionados a logística de uma determinada empresa, entre alguns o custo de armazenamento, custo de existência custo de encomendas e custos de transportes. (ALMEIDA, 2019).

Entende-se que o custo logístico voltado para o setor de cargas perigosas seja ainda mais rigoroso, pois seu planejamento e processo de transporte deve seguir regras e procedimentos a fim de evitar contaminações e despejos involuntários.

O Departamento Nacional de Infraestrutura de Transportes (DNIT), órgão responsável pela infraestrutura de transportes no país, determina que os produtos de natureza perigosa são todos aqueles de origem química, biológica ou radiológica que são nocivos ao meio ambiente, à população e aos seus bens. (LOTUS, 2020).

O material que ocasionar contaminação no solo, água, lesões na fauna e flora, intoxicação de pessoas entre outros aspectos são considerados produtos perigosos e necessitam de transporte estratégico adequado para que não ocorra contato indesejado em locais inapropriados. De acordo com ABNT (Associação Brasileira de Normas Técnicas), devem estar acompanhados da ficha de emergência (Figura 4), informando as características do produto e os planos de ação em caso de sinistro durante o transporte terrestre. (ABNT NBR 7503:2020, 2020). 
Figura 4 - Ficha de emergência

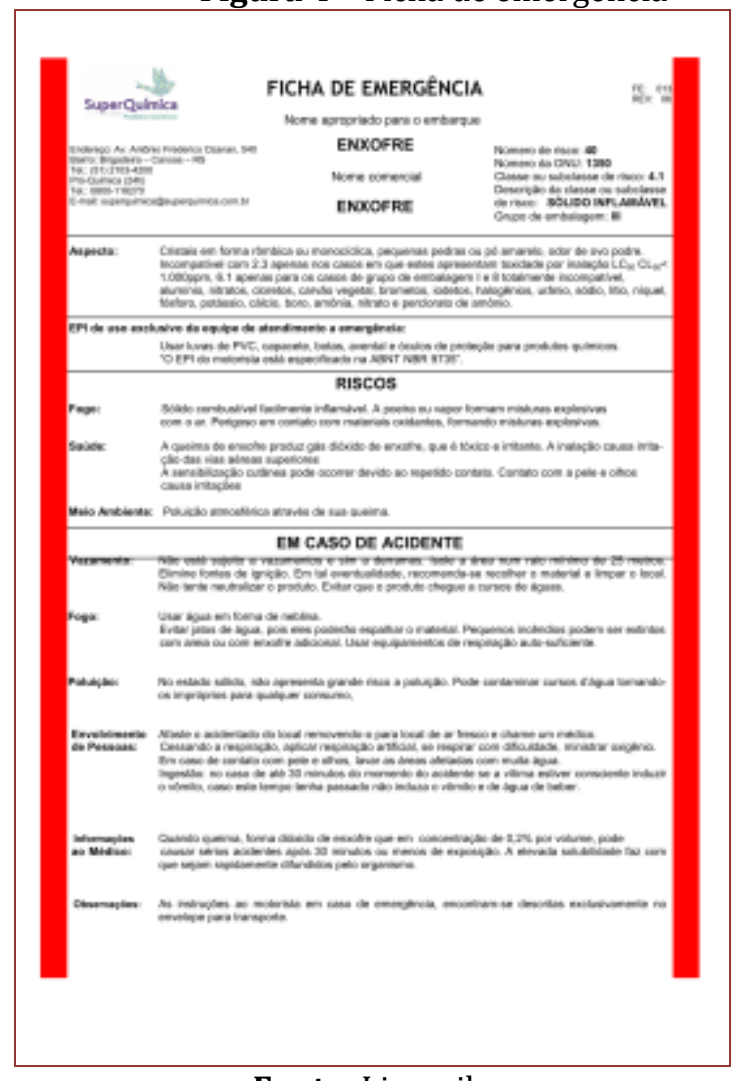

Fonte: Livrozila

Segundo a Fio Cruz (1998) o armazenamento adequado de substâncias químicas deve possuir: sistemas de ventilação por todo o local, sinalização funcional e correta, disponibilidade de EPI e EPC (equipamentos de uso individual e coletivo), setor administrativo separado do setor de armazenamentos e técnico.

De acordo com Pedrolo, (2014) o transporte logístico do enxofre, mineral muito utilizado no processo de produção do combustível, fibras, fertilizantes, medicamentos entre outros produtos, possui muitos cuidados e planejamento logístico, esse tipo de material é designada como carga perigosa já que se trata de uma substância altamente inflamável.

Segundo o gerente de ampliação Achilles Caporalli Filho (2016) os processos de movimentação e armazenagem de enxofre foram intensificados no Terminal Integrador Portuário Luiz Antônio Mesquita (TIPLAM), na unidade da VLI foi necessária a implantação do projeto de expansão em sua área de movimentação e armazenagem de enxofre, a medida implantada visou dobrar a capacidade de estocagem do produto e de todo sua movimentação.

De acordo com dados do próprio terminal (TIPLAM), o pátio podia receber até 66 mil toneladas do produto, após sua ampliação esse número subiu para 126 mil toneladas. Com sua infraestrutura a unidade da VLI ampliou sua movimentação do insumo de 1,5 milhão de toneladas para 2,1 milhão de toneladas por ano.

A ampliação do TIPLAM é essencial até hoje para possibilitar que o Corredor CentroSudeste ofereça soluções logísticas integradas, combinando capacidade e eficiência no transporte de carga. 
Por se tratar de um tipo de carga considerada de extremo risco o transporte de enxofre exige uma atenção redobrada em sua movimentação e deslocamento pois se umas das etapas acabar não saindo como o esperado grande consequências podem acabar prejudicando diversas partes envolvidas tais como a sociedade, os demais envolvidos com sua movimentação/transporte ou até mesmo o meio ambiente.

\section{RESULTADOS E DISCUSSÃO}

A partir da coleta de dados dessa pesquisa bibliográfica é possível identificar o modo que os autores sugerem como é importante que as companhias movimentem seus produtos, desde a cadeia de suprimentos até o consumidor final. Tem-se uma visão da importância de uma cadeia de suprimentos eficiente, pois é o que determina o sucesso de pequenas e grandes empresas. Devido à complexidade desse sistema fornecedora, representante e intermediários precisam entender como essa estrutura funciona, pois, a ideia é agregar valor ao produto.

Para diminuir custos é imprescindível o investimento na infraestrutura como é feito em países como Inglaterra e EUA, que investem na construção de portos e ferrovias, pois o custo logístico não agrega valor ao produto. 0 objetivo é diminuir custos com estocagem, e a redução do tempo entre compra e entrega dos produtos que é um dos maiores desafios das organizações, pois é preciso atender ao mercado para que se agregue valor ao tempo, garantindo aos clientes a disponibilidade de produto em grande demanda. $\mathrm{E}$ uma forma prática para atender esses clientes foi a unitização de cargas que acelerou esse processo distribuindo com maior eficiência suas mercadorias.

É eficiente quando se movimentam cargas com pequenas dimensões e grandes quantidades, porém quando se trata de cargas que fogem das dimensões comuns perde sua eficácia, pois é o caso das cargas especiais, que dependem de maquinas e equipamentos mais evoluídos para movimentar cargas que excedem as dimensões e peso e requerem regras especiais para trafegar por vias públicas como acontece no Brasil, uma vez que para movimentar cargas químicas e explosivas no território nacional devem-se seguir normas de órgãos reguladores.

0 objeto dessa pesquisa as cargas especiais perigosas, nitrato de amônio e enxofre movimentados na região portuária de santos através de terminais como o TIPLAM, são fiscalizados quanto a sua armazenagem e manuseio, requerendo atenção especial dos órgãos na prevenção de acidentes em várias esferas, principalmente ambiental.

Podemos concluir que é de extrema importância para as companhias seguir os métodos para armazenagem e transporte apresentados pelos autores, e seguir as regras e normas estabelecidas por órgãos públicos, pois os métodos trazem segurança, qualidade, produtividade e lucros, para as empresas, comunidade e ao meio onde estes estão inseridos. Acompanhando os processos desde a matéria prima na cadeia de suprimentos, até a entrega do produto aos clientes e consumidores. 


\section{CONSIDERAÇÕES FINAIS}

Tendo em vista alguns aspectos analisados pode-se dizer que o enxofre é um elemento químico encontrado na natureza, considerado um material perigoso de classe 4.

Sua ampla utilização exige que as companhias desenvolvam um local com uma infraestrutura de qualidade para que seu armazenamento e distribuição seja feito de forma correta e segura, assim evitando danos aos trabalhadores e ao meio ambiente. Para que o material seja armazenado de forma correta é necessário que as companhias tenham um acompanhamento da carga através de monitoramento eletrônico para analisar fatores como tamanho das embalagens que serão acomodadas e a estrutura do material (vidro, plástico e cerâmica). Para desenvolver uma logística de transporte adequada é necessário que haja controle da mercadoria que será transportada desde seu volume a custos e tempo.

\section{REFERÊNCIAS}

[1]. ANTAQ. Cargas Perigosas. Brasília-DF.2011. Disponível em: http://portal.antaq.gov.br/index.php/meio-ambiente/cargas-perigosas/. Acesso em 07 de set. 2020.

[2]. ANTT. Produtos Perigosos. Brasília-DF. 2019. Disponível em: https://www.antt.gov.br/produtos-perigosos. Acesso em 02 de set. 2020.

[3]. A TRIBUNA. Tiplam Iniciará Projeto de Expansão da Capacidade de Armazenagem e Movimentação de Enxofre e Fertilizantes. Santos-SP. 2016. Disponível em:https://www.globalfert.com.br/noticias/logistica/tiplam-iniciara-projeto-de-expansao-dacapacidade-de-armazenagem-e-movimentacao-de-enxofre-e-fertilizantes/. Acesso em 08 de set. 2020.

[4]. BRANCO, M.D.P. Enxofre (S). Recife - PE. 2002. Disponível em: http://dnpmpe.gov.br/Detalhes/Enxofre.htm. Acesso em 02 de set. 2020.

[5]. BRASIL CAMINHONEIRO. Movimentação do Porto de Santos cresce 9,6\% no primeiro bimestre. São Paulo - SP. 2018. Disponível em: http://brasilcaminhoneiro.com.br/porto-desantos-cresce/. Acesso em 04 de set. 2020.

[6]. MASTERSUL COMEX. Saiba quais são as Cargas que se enquadram como perigosas. Curitiba-PR. 2013. Disponível em: https://mastersul.com.br/blog/saiba-quais-sao-as-cargasque-se-enquadram-como-perigosas/. Acesso em 11 de set. 2020.

[7]. PRODANOV, C.C.; FREITAS, C.E. Metodologia do Trabalho científico: Métodos e Técnicas da Pesquisa e do Trabalho Acadêmico. $2^{2}$ edição. Nova Hamburgo-RS: Universidade Feevale. 2013.

[8]. SALDANHA, J. A. Classificação e Definição das Classes de Produtos Perigosos. Brasília-DF. 1997. Disponível em: https://www.invitare.com.br/arq/legislacao/anvisa/Portaria-204-de1997-Aprovar-as-anexas-Instru-es-Complementares-aos-Regulamentos-dos-TransportesRodovi-rio-e-Ferrovi-rio-de-Produtos-Perigosos.pdf. Acesso em 08 de set. 2020.

[9]. BALLOU, Ronald H. GERENCIAMENTO DA CADEIA DE SUPRIMENTOS/LOGÍSTICA EMPRESARIAL. 5. ed. Porto Alegre: Bookman, 2006.

[10]. MEUSUCESSO.COM (ed.). O que é cadeia de suprimentos? 2014. Disponível em: https://meusucesso.com/artigos/logistica/o-que-e-cadeia-de-suprimentos-322/. Acesso em: 05 out. 2020 .

[11]. BARAT, Josef. Logística Transporte e Desenvolvimento Econômico. [S. I.]: CLA, 2007. Disponível em: 
https://books.google.com.br/books?id=9PFnW_tDprUC\&lpg=PA9\&ots=SONDiI42LS\&dq=transp orte\&lr\&hl=pt-BR\&pg=PP1\#v=onepage\&q=transporte\&f=true. Acesso em: 6 out. 2020.

[12]. RUSSO, Clóvis Pires. Armazenagem, Controle e Distribuição. Curitiba: IBPEX, 2009. Disponível em:

https://books.google.com.br/books?id=Jdc3PMCNXs8C\&lpg=PP1\&dq=inauthor\%3A\%22CLOVIS \%20PIRES\%20RUSSO\%22\&hl=pt-BR\&pg=PA12\#v=onepage \&q\&f=true. Acesso em: 6 out. 2020.

[13]. SILVEIRA, Edgar Filipe Nunes. A IMPORTÂNCIA DA LOGÍSTICA DE TRANSPORTE NO COMÉRCIO EXTERIOR. A IMPORTÂNCIA DA LOGÍSTICA DE TRANSPORTE NO COMÉRCIO EXTERIOR, Florianópolis, 2010. Disponível em:

https://www.riuni.unisul.br/bitstream/handle/12345/1660/105584_Edgar.pdf?sequence=1\&i sAllowed=y. Acesso em: 7 out. 2020.

[14]. OLIVEIRA, Francisco Eduardo Lira Reis. Levantamento Logístico: análise das atividades de movimentação e armazenagem em um armazém distribuidor. Levantamento Logístico: análise das atividades de movimentação e armazenagem em um armazém distribuidor, Campina Grande, 2008. Disponível em:

http://dspace.sti.ufcg.edu.br:8080/jspui/bitstream/riufcg/5976/1/FRANCISCO\%20EDUARDO \%20LIRA\%20REIS\%20DE\%200LIVEIRA\%20-

\%20TCC\%20ADMINISTRA\%c3\%87\%c3\%830\%202008.pdf. Acesso em: 7 out. 2020.

[15]. SCHOLLER, Sadi Luís. A Movimentação de Cargas Pesadas em Portos Brasileiros: Dificuldades e Perspectivas. A Movimentação de Cargas Pesadas em Portos Brasileiros: Dificuldades e Perspectivas, Florianópolis, 2000. Disponível em: https://repositorio.ufsc.br/bitstream/handle/123456789/79304/175342.pdf?sequence=1\&isA llowed=y. Acesso em: 8 out. 2020.

[16]. CONTRAN - CONSELHO NACIONAL DE TRÂNSITO. RESOLUÇÃO № 211, DE 13 DE NOVEMBRO DE 2006 no RESOLUÇÃO № 211, DE 13 DE NOVEMBRO DE 2006, de 13 de novembro de 2006. Circulação de Combinações de Veículos de Carga - CVC. Requisitos necessários à circulação de Combinações de Veículos de Carga - CVC, a que se referem os arts. 97, 99 e 314 do Código de Trânsito Brasileiro-CTB. Circulação de Combinações de Veículos de Carga - CVC., [S. l.], 22 nov. 2006. Disponível em:

https://www.diariodasleis.com.br/busca/exibelink.php?numlink=1-48-34-2006-11-13211.Acesso em: 8 out. 2020.

[17]. UNECE (New York and Geneva). ONU. Globally Harmonized System of Classification and Labelling of Chemicals (GHS). Globally Harmonized System of Classification and Labelling of Chemicals (GHS), [S. 1.], 2017. Disponível em:

http://www.unece.org/fileadmin/DAM/trans/danger/publi/ghs/ghs_rev07/English/ST_SG_AC 10_30_Rev7e.pdf. Acesso em: 8 out. 2020.

[18]. TECNOLOGÍSTICA. Tiplam dobra capacidade de armazenamento de enxofre: 0 novo pátio terá possibilidade estática para armazenar 66 mil toneladas de enxofre. [S. l.], 29 jun. 2016. Disponível em: https://www.tecnologistica.com.br/portal/noticias/72124/tiplam-dobracapacidade-de-armazenamento-de-enxofre/. Acesso em: 8 out. 2020.

[19]. MINISTÉRIO DA DEFESA EXÉRCITO BRASILEIRO COMANDO LOGÍSTICO DEPARTAMENTO MARECHAL FALCONIERI. PORTARIA № 147 - COLOG, DE 21 DE NOVEMBRO DE 2019. EB: 64447.044665/2019-87. Instruções Gerais para a Fiscalização de Produtos Controlados pelo Exército, [S. l.], 21 nov. 2019. Disponível em: http://www.dfpc.eb.mil.br/images/Portarian147.pdf. Acesso em: 9 out. 2020.

[20]. PROJETO SIIPP: Classificação dos produtos perigosos. 2004. Disponível em: http://200.144.30.103/siipp/public/imprime_classificacao.aspx. Acesso em: 15 out. 2020.

[21]. DIÁRIO DO LITORAL (Santos). Reportagem. Nitrato de Amônio: duas vezes Hiroshima no Porto de Santos. Nitrato de Amônio: duas vezes Hiroshima no Porto de Santos, [S. l.], p. 1, 8 ago. 
2020. Disponível em: https://www.diariodolitoral.com.br/cotidiano/nitrato-de-amonio-duasvezes-hiroshima-no-porto-de-santos/136911/. Acesso em: 9 out. 2020.

[22]. ANTAQ (Brasil). Anuário. [S. l.], 2019. Disponível em: http://web.antaq.gov.br/anuario/. Acesso em: 10 out. 2020.

[23]. ALMEIDA, M. Custos Logísticos. João Pessoa-PB. 2019. Disponível em:

https://administradores.com.br/artigos/custos-logisticos. Acesso em: 10 de out. de 2020.

[24]. FIOCRUZ. Armazenamento de Produtos Químicos. Brasília-DF. 1998. Disponível em: http://www.fiocruz.br/biosseguranca/Bis/lab_virtual/armazenamento_de_produtos_quimicos. html. Acesso em 14 de out. de 2020.

[25]. LOGÍSTICA. Logística de Transporte. São Paulo - SP. 2019. Disponível em: https://sancagalpoes.com.br/logistica-transporte/. Acesso em: 10 de out. de 2020.

[26]. LOTUSLOG. Cargas Perigosas. Santos-SP. 2020. Disponível em: https://lotuslogbr.com.br/. Acesso em: 12 de out. de 2020.

[27]. PEDROLO, C. Elementos Químicos Enxofre. Santa Maria - RS. 2014. Disponível em: https://www.infoescola.com/elementos-quimicos/enxofre/. Acesso em 09 de out. de 2020.

[28]. GLOBALFERT. A Tribuna. Santos-SP. 2016. Disponível em:

https://www.globalfert.com.br/noticias/logistica/tiplam-iniciara-projeto-de-expansao-dacapacidade-de-armazenagem-e-movimentacao-de-enxofre-e-fertilizantes/ Acesso em: 16 de out. 2020.

[29]. VLI LOGISTICA. Tiplam SP. Santos-SP. 2020. Disponível em: https://www.vlilogistica.com.br/conheca-a-vli/portos/tiplam-sp/. Acesso em: 16 de out. 2020.

[30]. SANTOS, Renato. Práticas de Operações Portuárias. Santos - SP: DNA do Saber, 2015. Disponível em: http://www.dnadosaber.com.br/onepage. Acesso em: 1 nov. 2020.

[31]. FICHA de Emergência. [S. l.], 2020. Disponível em: https://livrozilla.com/doc/708161/ficha-de-emerg\%C3\%AAncia---superquimica.com.br. Acesso em: 3 nov. 2020.

[32]. PORTOS E NAVIOS. Tiplam SP. Santos-SP. 2020. Disponível em: https://www.portosenavios.com.br/noticias/portos-e-logistica/tiplam-iniciara-fase-de-testesde-novo-patio Acesso em: 16 de out. 2020. 


\section{Capítulo 12}

\section{Aplicações do machine learning: Seu uso como ferramenta de otimização portuária}

\section{Victoria Marques Riechelmann \\ Vinicios Santos da Silva}

Resumo: Atualmente a logística portuária tem sido fortemente modificada em prol da tecnologia, ghost ports são a realidade ao redor do globo. Economias vêm sendo impulsionadas devido a máquinas com o potencial de exercer de forma sistemática funções com maior agilidade e precisão. Apesar disso, é comum se deparar com alguns gargalos logísticos nos quais tecnologias avançadas vêm demonstrando grande potencial para a sua solução. 0 presente artigo busca evidenciar a importância do desenvolvimento e aplicação de tecnologias como o Machine Learning em operações portuárias envolvendo a conferência de contêineres refrigerados.

Para o desenvolvimento deste trabalho foi realizada uma revisão bibliográfica para levantar fundamentos sobre os assuntos abordados, sendo posteriormente feita uma coleta de dados para apresentar o cenário logístico atual no Brasil e assim analisar de que forma as evidências podem colaborar para a resolução da problemática em questão.

Palavras-chave: Machine learning. Inteligência artificial. Monitoramento de reefer's. 


\section{INTRODUÇÃO}

Apesar de diversos avanços em questões organizacionais e tecnológicas, o setor portuário brasileiro ainda possui diversos entraves que prejudicam o seu desempenho e afetam a cadeia logística como um todo, impactando principalmente o cliente final. Um desses problemas trata-se do monitoramento de temperatura de contêineres reefer, que atualmente é comum em portos nacionais ver este serviço sendo realizado de forma totalmente manual, necessitando de pessoal in loco constantemente verificando e regulando seus parâmetros, se tornando um processo frágil a diversos imprevistos como o erro de leitura do painel da unidade.

Por meio de contêineres refrigerados são unitizados insumos hospitalares, medicamentos, alimentos perecíveis e produtos químicos. Este tipo de mercadoria necessita estar sob controle constante de temperatura, podendo sofrer perda caso seu sistema sofra instabilidade, ocorra atraso na sua conferência ou equívocos na manutenção de condições, mercadoria esta que possui em grande parte alto valor agregado.

A inteligência artificial é um dos pilares da Revolução 4.0 e cada vez mais tem se descoberto diferentes maneiras de aplicar as diversas vertentes da IA de forma a nos propiciar maior otimização, principalmente de custo e tempo, nas mais variadas áreas da sociedade. Esta tecnologia desempenha atualmente um papel de suma importância na logística 4.0, tendo em vista que softwares avançados tem sido cada vez mais utilizados a fim de minimizar gargalos logísticos e maximizar resultados. Sistemas complexos como o Machine Learning simulam o aprendizado humano em máquinas, sendo assim o computador passa a ser apto a compreender e reproduzir padrões para obter resultados, pré-determinados ou não.

Este estudo tem como objetivo evidenciar os benefícios da utilização de novas tecnologias na logística a fim de instigar o mercado à utilização de novos sistemas de apoio portuário com aplicações cada vez mais precisas e, assim, impulsionar a cadeia logística nacional a obter cada vez mais posições de destaque competitivo em relação ao comércio internacional. Para isso, modelos estatísticos de programação, algoritmos e métodos como o Machine Learning mostram grande potencial na solução de entraves como o monitoramento de contêineres reefer a distância.

Para a construção deste artigo científico foi realizada uma revisão bibliográfica a fim de levantar fundamentos sobre os assuntos expostos, muitos desses dispersos e sem relação entre si. Posteriormente, por meio de pesquisa em sites governamentais ou homologados, foram coletados dados para apresentar o atual cenário da logística no país e assim analisar de que forma a problemática pode ser solucionada a partir das evidências coletadas.

\section{PANORAMA LOGÍSTICO}

Um dos pilares da economia brasileira é o comércio internacional, sendo esta atividade responsável por expandir as negociações de mercadorias e serviços para além do território nacional e que apenas no primeiro semestre de 2020 foi responsável por US\$ 101,1 bilhões em exportações e US\$ 79,4 bilhões em importação, obtendo um saldo de US\$ 21,69 bilhões. No Brasil, os produtos mais exportados são os commodities, representando aproximadamente $60 \%$ das exportações no último ano, tendo se destacado a soja (16\%), minérios de ferro (12\%) e os óleos brutos de petróleo $(9,5 \%)$ 
(COMEX VIS, 2020). No entanto, apesar de movimentarmos commodities a granel em maior quantidade, os mesmos possuem valor agregado inferior quando comparado a cargas conteinerizadas, também com forte movimentação no território nacional. Além disso, novas tecnologias têm sido estudadas a fim de aumentar a utilização de contêineres também para commodities, como é o caso dos contêineres bulk (imagem 1) e o novo equipamento de transporte ferroviário contando com vagões double-stack (imagem 2) que possibilitam o aumento da eficiência logística e propiciam a diminuição da perda de carga durante o transporte, além da redução de custos operacionais e de combustível gasto para transporte (RIECHELMANN, MESQUITA, SILVA, 2019).

Imagem 1 - Container Bulk

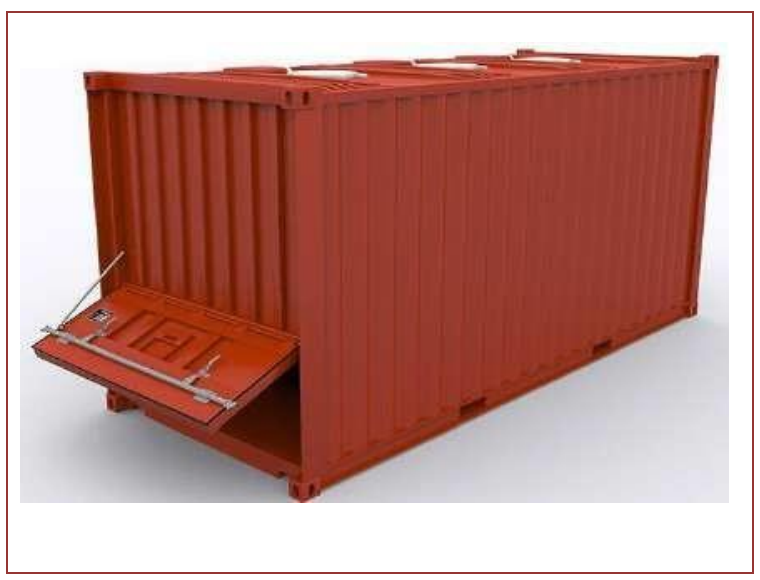

Fonte: V3 Shipping, 2018

Imagem 2 - Vagões Double Stack

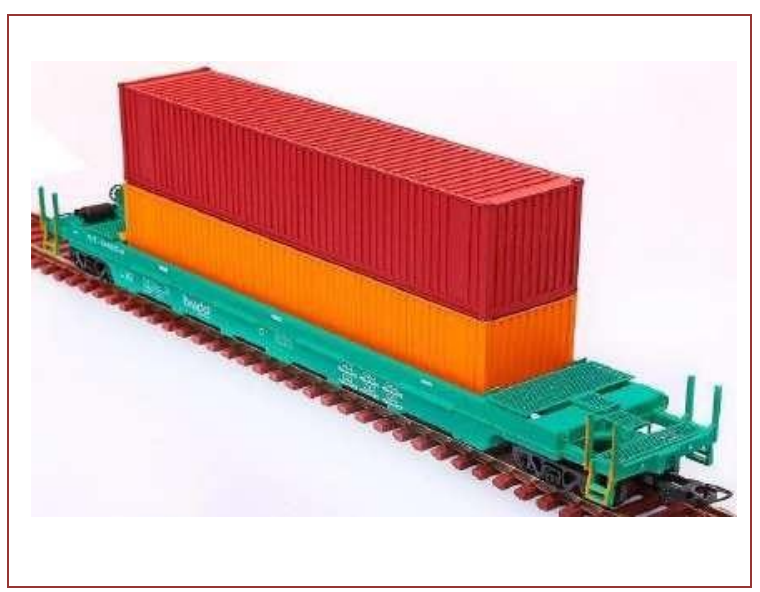

Fonte: Porto e Notícias, 2019

De acordo com a ANTAQ (Agência Nacional de Transporte Aquaviário, 2020), em relação ao desempenho dos portos brasileiros no primeiro semestre de 2020, desponta-se em relação a movimentação de carga em peso bruto os portos de Ponta da Madeira (15\%), Santos (10,3\%), Angra dos Reis (5,8\%), Paranaguá (4,8\%), São Sebastião $(4,7 \%)$ e Tubarão (4,6\%). Muitos destes, como é o caso da Ponta da Madeira, justifica-se o alto volume devido ao tipo de carga movimentada, sendo destinado completamente a minério de ferro, produto este de grande densidade, mas com baixo valor de negociação. 
No mesmo período foram movimentados quase 5 milhões de TEU (Twenty Foot Equivalent Unit), sendo 67,7\% voltado ao longo curso e $31 \%$ à cabotagem. Deste volume, cerca de $67 \%$ foram em porto público e $32,3 \%$ em porto privado, destacando- se o porto de Santos (37,8\%), seguido de Paranaguá (9\%), Navegantes (7,3\%) e Itapoá $(7,1 \%)$. A partir desses dados é possível dimensionar o volume de carga que se utiliza do contêiner como a principal forma de unitização, tornando extremamente importante as atividades de planejamento de pátio, planejamento de navio e controle de temperatura para os reefers que resultam em 16,7\% do volume total (ANTAQ, 2020).

\subsection{MONITORAMENTO DE REEFER'S}

No Brasil temos uma presença expressiva de carga refrigerada nos transportes nacionais e internacionais, conforme imagem 01 , dando ênfase à importância da cadeia de frio na economia brasileira. Chamamos de cadeia de frio (cold chain) toda a logística de movimentação, transporte e armazenagem de carga refrigerada desde a produção até o consumidor final (PACHECO, G. 2019). Para que esta logística seja realizada, são necessários equipamentos e veículos específicos com controle de temperatura e isolação térmica, sendo os contêineres reefer uma peça crucial para realização deste tipo de transporte.

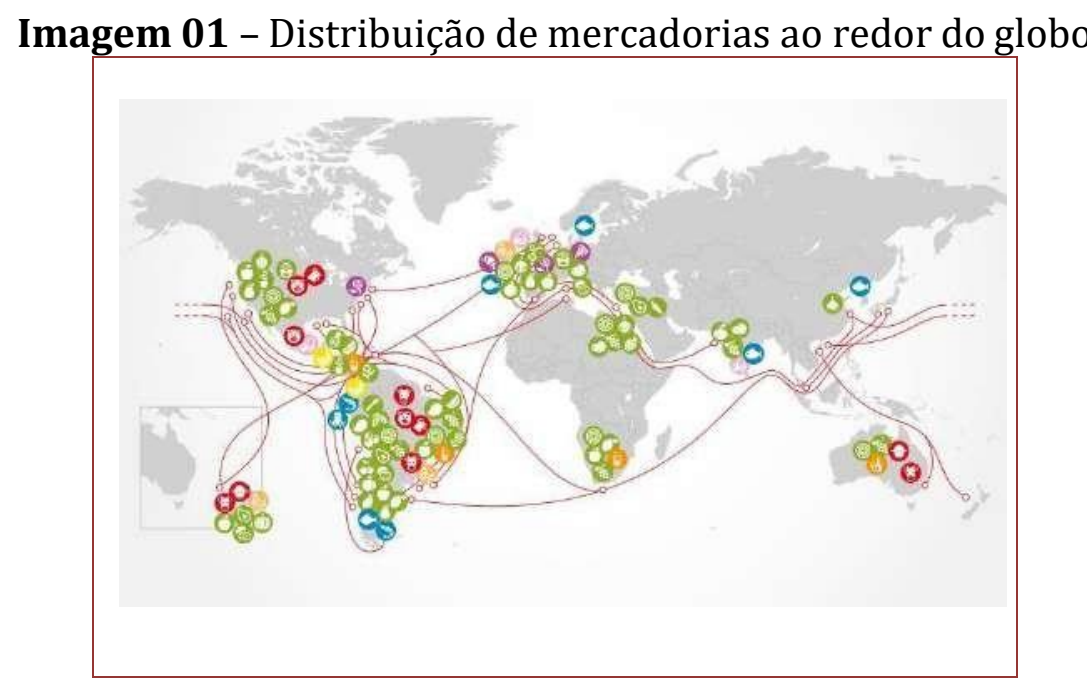

Fonte: Hamburg Sud (2019)

Os contêineres refrigerados permitem ajuste de temperatura de $-35^{\circ} \mathrm{C}$ até $+30^{\circ} \mathrm{C}$ (CANEO, N., DIAS, 2019), permitindo assim o transporte seguro e confiável desde carnes e alimentos à medicamentos e vacinas. Mesmo que o transporte não seja breve, este equipamento possibilita armazenamento da mercadoria em temperatura constante pelo tempo em que tiver uma fonte geradora de energia conectada a ele. Os contêineres reefer são equipados com plugs para conexão em tomadas, podendo também ser conectados a geradores de energia movidos a diesel (PACHECO, G. 2019).

Por serem equipamentos elétricos, estão sujeitos a interferências externas que podem comprometer seu desempenho e, consequentemente, impactar diretamente na integridade da carga devido a temperatura não compatível com o armazenamento da mercadoria. Queda de energia, intempéries e problemas físicos nos componentes deste tipo de contêiner são intercorrências que devem ser identificadas e solucionadas com 
maior brevidade. 0 parâmetro normalmente utilizado para monitoramento da integridade e funcionamento dos reefer's é a temperatura interna do mesmo.

Apesar do avanço tecnológico disponível no mercado, ainda é comum vermos em terminais nacionais este serviço de monitoramento sendo realizado de forma manual, com pessoas in loco, conforme imagem 02. Esta inspeção, quando realizada de forma manual, fica suscetível a erros e interpretações incoerentes, podendo prejudicar a integridade da carga e confiabilidade da armazenagem.

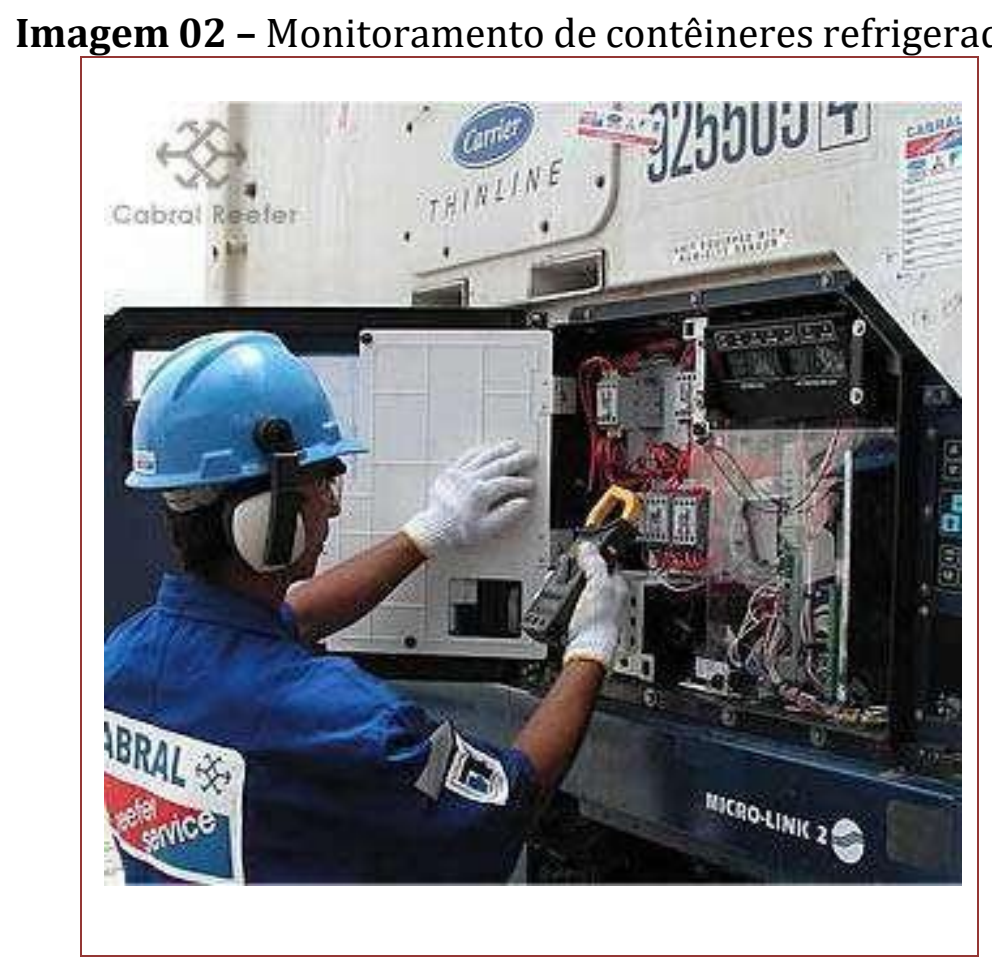

Fonte: Tek Reefers Services (2019).

Estamos vivendo hoje a revolução 4.0, época em que no nosso dia a dia nos deparamos com tecnologias avançadas realizando tarefas que antes dependiam do suporte e realização humana. A Inteligência Artificial e a Internet das Coisas (Internet of Things IoT) vêm se mostrando cada vez mais eficazes no desempenho de tarefas em que, quando feitas com mão de obra humana, apresentavam certa parcela de erros. Por serem tecnologias programadas para agirem de forma pré definida sobre determinada circunstância, o serviço prestado é feito de forma uniforme e padronizada, tendo como exceção a ocorrência de falhas na programação das funções ou dano em componentes físicos. Como esperado, o setor portuário vem sendo fortemente impactado de forma positiva pelo desenvolvimento e aplicação destas tecnologias.

\section{INTELIGÊNCIA ARTIFICIAL}

Existem hoje diversas definições sobre o que é de fato a indústria 4.0, definições variantes, porém complementares de acordo com pontos de vista individuais. Segundo Hermann, Pentek e Otto (2015), a indústria 4.0 pode ser definida como um termo coletivo que engloba tecnologias e conceitos de cadeia de valor de uma organização. Já Sacomano e Sátyro (2018), definem indústria 4.0 como sendo um sistema produtivo constituído por computadores, dispositivos móveis e conexão à internet e/ou intranet 
que possibilita o gerenciamento e controle, entre outros aspectos com o sistema produtivo situado em qualquer lugar do planeta, buscando assim aperfeiçoar os principais aspectos empresariais. Independente da definição pessoal de cada um, é unanime a percepção de que esta nova era da tecnologia trará grandes mudanças a sociedade que hoje conhecemos.

Um dos desenvolvimentos que vem apresentando maior avanço tecnológico e tem se mostrado mais promissor nas mais diversas áreas da sociedade é o ramo de Artificial Intelligence, que tem por objetivo simular a capacidade de raciocínio humano em máquinas na resolução de problemas (SACOMANO e SÁTYRO, 2018). A AI, como é abreviada, teve sua criação baseada nos esforços de cientistas da década de 50 em criar modelos computacionais da lógica humana, tendo o termo sido utilizado pela primeira vez em 1956 no evento Dartmouth Summer Research Project on Artificial Intelligence (Projeto de Pesquisa de Verão de Dartmouth sobre Inteligência Artificial), evento este que reuniu um grupo de dez cientistas que conquistaram avanços importantes no desenvolvimento da tecnologia (KAUFMAN, 2019).

Ao redor do globo podemos buscar exemplos de Inteligência Artificial aplicada em terminais portuários, como é o caso do Porto de Rotterdam, localizado no sul da Holanda. 0 porto em questão é conhecido como um ghost port devido a ausência de necessidade de pessoas trabalhando de forma direta nos terminais, deixando a sua área operacional totalmente livre da presença humana. Os terminais são equipados com tecnologias que integram uma torre de controle através da qual são realizadas as liberações de gate e operação de guindastes. Tamanho nível de automação resultou ao porto de Rotterdam a redução de acidentes dentro do terminal, acarretando na redução de interrupções de trabalho e custos operacionais (ARAÚJO. 2019).

\subsection{MACHINE LEARNING (APRENDIZADO DE MÁQUINA)}

Um dos avanços mais recentes da Artificial Intelligence é o Machine Learning, sistema no qual a máquina é programada a simular o aprendizado humano possibilitando que computadores tenham tomadas de decisão baseadas em padrões observados e aprendidos pelo mesmo. Assim como os seres humanos, a $M L$ utiliza de experiências contempladas pela máquina como forma de aprendizado por meio de algoritmos e dados reais (Portugal, et al., 2018), para que assim possa construir modelos matemáticos e aplicá-los nas mais diversas situações, gerando conclusões,tomadas de decisão e insights (GESING, et al., 2018). 0 sistema funciona com base eminputs e outputs, os dados a serem aprendidos são processados pelo sistema de $A I$ que, por meio de algoritmos, organiza os dados enviados e por fim ocorre a saída em forma de padrões ou tendências, conforme imagem 3 (Gesing, 2018). 
Imagem 3 - Estrutura Geral de Machine Learning

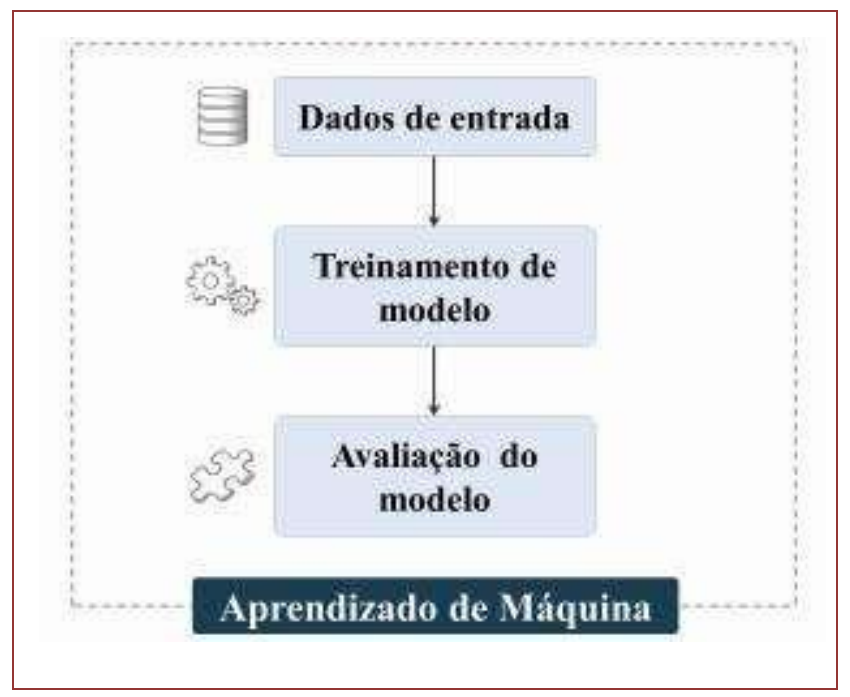

Fonte: RODRIGUES, E. Y. A. 2018.

Os métodos para desenvolvimento do ML dividem-se basicamente em cinco. A aprendizagem supervisionada (Supervised Learning, SL), metodologia que requer o processamento de dados pré rotulados por seres humanos para prever as saídas. Aprendizagem não supervisionada (Unsupervised Learning, USL), na qual a máquina observa e avalia o ambiente por conta própria para processar os dados e combiná-los para assim obter padrões. Aprendizagem semi supervisionada (Semi-Supervised Learning, $S S L$ ) que, como pode ser deduzido através da nomenclatura, é um método de aprendizado que intermedia a $S L$ e a $U S L$, permitindo que a máquina capte e processe os dados por conta própria, porém contando com ajuda humana para delimitação dos resultados desejados. Aprendizagem por reforço (Reinforcement Learning, $R L$ ), técnica em que a máquina aprende por meio de tentativas e erros, analisando os feedbacks para detecção da falha e assim ter a possibilidade de escolha entre qual decisão leva a um melhor resultado. Por último, temos o método de aprendizagem profunda (Deep Learning, $D L$ ), um método de maior complexidade que mescla algoritmos de $S L$ e de $U S L$ para que o modelo aprenda representações em formato de hierarquia (Rodrígues,2020).

\section{PROPOSTA DE OTIMIZAÇÃO}

Cada vez mais a inteligência artificial tem se mostrado importante na resolução de problemas cotidianos e isso inclui os gargalos logísticos abordados neste estudo. A utilização de tecnologias inteligentes programadas para o Machine Learning resolveria de forma eficaz a questão do monitoramento físico da temperatura de reefers.

Atualmente tecnologias de RFID já vem sendo estudadas para esta finalidade que, apesar de resolver grande parte dos pontos já citados, ainda seria necessária a conferência e análise dos dados coletados por um colaborador. Com a implementação da $A I$ para o monitoramento de temperatura das unidades reefer, a conferência, controle e reajuste de temperatura se torna um trabalho inteiramente automatizado, possibilitando o controle de maior quantidade de equipamentos simultaneamente e dispensando assim a necessidade de mão de obra humana na realização do trabalho. 


\section{CONSIDERAÇÕES FINAIS}

É de extrema relevância o uso da tecnologia como aliada para o ganho de competitividade no âmbito corporativo, sobretudo no setor logístico, o qual impacta de forma considerável a vida de todos entorno do globo. Sendo assim, a inteligência artificial ou, especificamente o aprendizado de máquina, é capaz de concretizar ganhos inestimáveis para as organizações no que tange a atividades de grande complexidade. No ramo industrial e principalmente no exterior isso já é uma realidade, algo que se vê não apenas como diferencial, mas sim como um requisito para a sobrevivência.

Quando se fala do ramo portuário, é notório o crescente desenvolvimento de terminais e armazéns mundo afora em decorrência da utilização de novas tecnologias. É possível concluir que em grande parte das atividades de execução, as máquinas desempenham o papel com maior conformidade que a mão de obra humana, contando com maior agilidade e incisão. No entanto, ainda existem pontos que podem ser aprimorados para acompanhar e alavancar tal avanço, aplicando-o principalmente a nível nacional que atualmente ainda se mostra obsoleto perante as tecnologias utilizadas em relação às que cada vez mais tem se tornado comum na era da revolução 4.0.

Sendo assim, com este trabalho espera-se instigar desenvolvedores, empresas de tecnologia e empresários da logística portuária nacional ao progresso aplicando, mas não se limitando, as tecnologias até então citadas. Para isto, ainda é necessário quebrar a linha quanto aos valores que se têm atualmente, abrindo espaço e gerando incentivos para as áreas e projetos voltados à inovação e empreendimento corporativo.

\section{REFERÊNCIAS}

[1]. Agência Nacional de Transporte Aquaviário (ANTAQ). Anuário. 2020. Acesso em: 03 nov de 2020. Disponível em:

http://anuario.antaq.gov.br/QvAJAXZfc/opendoc.htm?document=painel\%5Cantaq\%20\%20anu\%C3\%A1rio\%202014\%20-\%20v0.9.3.qvw\&lang=pt-

BR\&host $=Q V S \% 40$ graneleiro\&anonymous=true

[2]. AIRES, C. S. F. ALMEIDA, G. J. SILVEIRA, S. O. Inteligência Artificial na Gestão de Estoque. FATEC SEBRAE, 2019. Disponível em:

http://fateclog.com.br/anais/2019/INTELIG\%C3\%8ANCIA\%20ARTIFICIAL\%20NA\%20

GEST\%C3\%830\%20DE\%20ESTOQUE.pdf Acesso em: 11 nov de 2020.

[3]. ARAÚJO, I. M. F. A. OLIVEIRA, L. LAPETINA, R. R. T. GONÇALVES, A. L. Automação de Terminal de Contêineres. Universidade Santa Cecília, 2019. Disponível em: lhttps://www.unisantos.br/wp-content/uploads/2019/12/Anais-do- 1o-Encontro-Nacional-deLog\%C3\%ADstica-Transportes-e-Mobilidade-Urbana.pdfAcesso em: 08 nov de 2020.

[4]. Comex Stat (Estatísticas de Comércio Exterior). Brasil: Informações Gerais. 2020.

Disponível em: http://comexstat.mdic.gov.br/pt/comex-vis Acesso em: 28 out de 2020.GESING, B. PETERSON, S. J. MICHELSEN, D. Artificial Intelligence in logistics. DHL Customer Solutions \& Innovation, 2018. Disponível em: https://www.dhl.com/content/dam/dhl/global/core/documents/pdf/glo-core-trend-reportartificial-intelligence.pdf Acesso em: 20 nov de 2020.

[5]. Instituto de Ciência, Tecnologia e Qualidade. Coronavírus: Dificuldade na Importação de Insumos Afeta 23 Medicamentos. 2020. Disponível em: https://www.ictq.com.br/industriafarmaceutica/1356-coronavirus-dificuldade-na-importacao-de-insumos-afeta-23-medicamentos Acesso em: 19 out 2020 
[6]. KAUFMAN, D. Inteligência Artificial: Repensando a Mediação. Brazilian Journal of Development, 2020. Disponível em:

https://www.brazilianjournals.com/index.php/BRJD/article/view/16372/13390 Acesso em: 19 out 2020.

[7]. KAUFMAN, D. A Inteligência Artificial Irá Suplantar a Inteligência Humana? 2019.Editora Estação Letras. Disponível em: https://books.google.com.br/books/about/A_intelig\%C3\%AAncia_artificial_ir\%C3\%A1_ suplanta.html?id=Fh-

WDwAAQBAJ\&printsec=frontcover\&source=kp_read_button\&redir_esc=y\#v=onepage \&q\&f=false Acesso em: 03 nov 2020.

[8]. PACHECO, G. Aplicação de Rede de Sensores Sem Fio no Monitoramento de Cargas Refrigeradas em Porto Seco. Universidade Tecnológica Federal do Paraná,2019. Disponível em: http://repositorio.roca.utfpr.edu.br/jspui/bitstream/1/16117/1/CT_CEIOT_II_2019_05.pdf Acesso em: 03 nov 2020.

[9]. Porto e Notícias. Vagões de Trem Double Stack Entram em Operação no Brasil. 2019. Disponível em: https://portoenoticias.com.br/interna/destaque-portuario/vagoes-de-tremdouble-stack-entram-em-operacao-no-brasil Acesso em: 18 nov 2020.

[10]. PORTUGAL, I. ALENCAR, P. COWAN, D. The use of Machine Learning Algorithms in Recommender. University of Waterloo, 2017. Disponível em: https://www.sciencedirect.com/science/article/abs/pii/S0957417417308333 Acessoem: 19 out 2020 .

[11]. RIECHELMANN, V. MESQUITA, V. SILVA, V. Análise de Perdas na Cadeia Produtiva do Açúcar: Modais Ferroviário e Rodoviário. FATEC RUBENS LARA,2019. Disponível em: https://docs.google.com/document/d/1WcvOxK1byl6-

EuMd8knsa3gBmtVosRv7UhFp9poFjIw/edit?usp=sharing Acesso em: 01 nov 2020.

[12]. RODRÍGUEZ, E. Y. A. Técnicas de Aprendizado de Máquina Para Predição do Custo da Logística de Transporte: Uma Aplicação em Empresa do Segmento deAutopeças. Universidade Estadual Paulista, 2020. Disponível em: https://repositorio.unesp.br/handle/11449/192326 Acesso em: 25 nov 2020

[13]. SACOMANO, J. B. SÁTYRO, W. C. GONÇALVES, R. F. SILVA, M. T. BONILLA, S. H.

[14]. Indústria 4.0: Conceitos e Fundamentos. 2018. Editora Edgard Blucher LTDA. Disponível em: https://books.google.com.br/books?hl=pt-

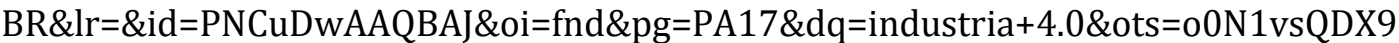
\&sig=c2J3cN-FVl1dsLxclM1-h37yGn8\#v=onepage \&q\&f=true Acesso em: 29 out 2020.

[15]. V3 Shipping. Especificação de Contêineres: Container Bulk. 2016. Disponível em: http://www.v3shipping.com.br/containers.html\#bulk_container Acesso em: 26 nov 2020.

[16]. Jornal do Comércio. Cresce procura por transporte e armazenagem de itens essenciais. 2020. Disponível em:

https://www.jornaldocomercio.com/_conteudo/cadernos/jc_logistica/2020/04/735911cresce-procura-por-transporte-e-armazenagem-de-itens-essenciais.html Acesso em:26 nov 2020.

[17]. Universidade Tecnológica Federal do Paraná. Aplicação de Rede de Sensores semFio no Monitoramento de Cargas Refrigeradas em Porto Seco. 2019. Disponível em: http://repositorio.utfpr.edu.br/jspui/bitstream/1/19671/1/CT_CEIOT_II_2019_05.pdf

[18]. CANEO, A. N, C. DIAS, M. Movimentação de Contêineres Refrigerados. 2019.Congresso Internacional de Tecnologia e Gestão.Disponível em: https://even3.blob.core.windows.net/anais/139645.pdf 


\section{Capítulo 13}

\section{Cargas indivisíveis da matriz eólica no desenvolvimento da região nordeste do Brasil}

\section{Danyel Santiago Santos Dirk \\ Sidney Evangelista Araujo \\ Jose Carlos Santos Santana}

Resumo: Ao longo da implantação da matriz eólica suas cargas indivisíveis pás e aerogeradores veem nos impondo obstáculos consideráveis ao passo que investimentos em sua tecnologia nos proporcionou desenvolvimento através de suas exportações além de sua enorme contribuição na produção de energia alavancando o progresso de regiões do país que outrora viviam a margem de apagões e pouco interesse em investimentos não só por parte do governo como também da iniciativa privada.

A produção do maquinário advindas das empresas estrangeiras e nacionais direcionadas não só a exportação como também a produção de energia repôs não só os estados das regiões Nordeste e Sul no caminho do desenvolvimento social em sua plenitude como trouxe um alento a regiões do Brasil onde predomina a agropecuária de forma a facilitar a sua produção e escoamento. Através do investimento dos setores público e privado suas dificuldades acabaram por ficar a sombra do êxito em ganhos expressivos que as partes envolvidas no processo alcançaram. Dessa forma mediante os termos expostos justifica-se o presente artigo pela essencial relevância dessas cargas vinculadas a matriz eólica no processo de desenvolvimento do Nordeste e Sul do Brasil e do país como um todo. Portanto este artigo tem por objetivo trazer a margem da luz não só a situação atual, mas expor explicitamente os processos pelos quais pás e aerogeradores no que diz respeito a manutenção, escoamento e produção se tornaram um obstáculo árduo a fabricantes e produtores onde a engenhosidade no exercício de busca por um êxito satisfatório frente a durabilidade do maquinário tornou-se um fator em comum a todos os países destinados a implantação dessa matriz. Para tanto utilizamos como metodologia a pesquisa descritiva, tendo como base fatos observados e documentados, além de fontes de dados governamentais, artigos e livros.

Palavras chave: Energia, eólica, exportação. 


\section{INTRODUÇÃO}

A energia advinda do petróleo é um processo que vem sendo findado gradualmente e sua crise nos anos 70 abriu um leque para o surgimento de fontes renováveis dentre elas a energia eólica aonde nos cabe salientar a enorme dificuldade no deslocamento de suas peças como: pás e aerogeradores eólicos e uma considerável dificuldade em manutenção decorrente das grandes elevações em que se encontram após a montagem de uma torre eólica ressaltando ainda seu pouco tempo de vida útil por estar sujeito constantemente as intemperes do meio ambiente haja visto que uma pá ou aerogerador tem durabilidade de cerca de 20 anos segundo análise da UL DEWI, empresa da UL focada em energias renováveis. Apesar das dificuldades segundo a (ABEEólica 22/07/2020), Associação Brasileira de Energia Eólica afirma que a capacidade instalada no país chegou à marca de $16 \mathrm{GW}$ no primeiro semestre de 2020 . São 637 parques eólicos e 7.738 aerogeradores.

A princípio nos deparamos na dificuldade de importar ao passo que hoje nem tanto devido a aquisição de grandes parques eólicos em regiões do país com maior incidência de ventos e a implantação de empresas estrangeiras em nosso território. No entanto o deslocamento se tornou um fator preocupante por se tratar de peças indivisíveis excedendo consideravelmente o modal de transporte além de ressaltar o seu enorme peso em toneladas mas, segundo Elbia Melo apesar, das dificuldades por ser tratar de uma indústria nascente é preciso ter folego , não pode ser algo que começa e depois é interrompido, pois isso pode ser fulminante" (ABEEÓLICA 2013).

\section{CONTEXTUALIZAÇÃO}

0 progresso econômico da Região Nordeste está intimamente vinculado ao desenvolvimento da matriz eólica mais especificamente seu maquinário onde aqui se põe em evidenciar a pá eólica. Sendo o Nordeste uma região pouco suprida de recursos hídricos para a construção de hidrelétricas, mas extremamente rica na matéria prima que alimenta a matriz investir em pesquisa e projetos tecnológicos que venham a intensificar o tempo em operação das pás eólicas é dar garantia de um futuro seguro para o desenvolvimento industrial em todos os setores empresariais e econômico a nível regional e nacional. 0 transporte, manutenção e principalmente durabilidade das pás eólicas é o desafio a ser conquistado e o caminho a ser percorrido para esse fim é a tecnologia e integralização em sua cadeia logística de suprimentos. No decorrer de aproximados 20 anos de investimentos no setor o país construiu uma segunda Itaipu em geração de energia ao ultrapassar a marca de 14,34 GW (gigawatts) de capacidade instalada além de abastecer $30 \%$ do Nordeste tirando a região do senário dos apagões elétricos o que vem a justificar e esclarecer a importância em investimentos ao maquinário do setor. Segundo Sandro Yamamoto ela é a fonte mais competitiva, vende a energia pelos melhores preços, e contribui para a tarifa residencial não ser tão alta, e ainda participa com 9\% da matriz elétrica (ABEEÓLICA - 2019).

\subsection{OBJETIVO GERAL E ESPECÍFICO}

O trabalho objetiva-se a apresentar uma análise ampla da implantação da matriz eólica na região nordeste do Brasil enfatizando de forma especifica as pás eólicas e suas entraves em deslocamento, durabilidade e produção. 


\subsection{METODOLOGIA CIENTIFICA}

0 trabalho teve sua construção fundamentada em fatos averiguados no cotidiano postulando continuamente por uma melhor condição ao objeto questionado futuramente contudo acatando as exigências e métodos específicos de uma pesquisa cientifica. Pesquisa cientifica é o estudo de fenômenos naturais ou fatos observados pelo homem em seu cotidiano tendo por finalidade esclarecer sua incógnita e possivelmente construí um novo conhecimento através do seu esclarecimento. A pesquisa cientifica tem como característica processos sistemáticos, controlado e criticamente reflexivo que permite a descoberta de novos fatos ou dados, relações ou leis em qualquer campo do conhecimento. 0 processo fornece aos pesquisadores uma compreensão da realidade ou verdade parcial. Neste trabalho de pesquisa serão abordados os métodos de revisão bibliográfica, qualitativa e quantitativa. A análise bibliográfica vem a suprir o pesquisador de uma gama de acervos documentais mais ampla como: livros, artigos e teses elaboradas por outros pesquisadores de forma que na observância dos fatos lhe possibilite detectar incoerências e contradições nas informações descritas via órgão público ou privado. A análise qualitativa considera o ambiente natural como sua fonte de coleta de dados e está focada no processo e seu significado admitindo uma relação entre o mundo real e o sujeito o que não pode ser traduzido em números. A análise quantitativa aborda as ferramentas estatísticas de forma a dar exatidão na coleta, e organização dos dados pesquisados dando agilidade aos pesquisadores nas tomadas de decisões (Richardson 1989).

\section{FUNDAMENTAÇÃO TEÓRICA}

O estudo da cadeia de suprimentos está inserido constantemente no ensejo das Organizações em encontrar um êxito satisfatório nas atividades de manipulação e deslocamento da matéria-prima visando garantir um produto acabado de boa qualidade com intuito de suprir o consumidor de uma mercadoria final com preço acessível ao seu poder aquisitivo de forma a manter a relação consumidor produtor em um fluxo continuo de compra e venda onde a meta principal está em manter o polo industrial em evolução e progresso ininterrupto (BALLOU - 2006).

A busca da empresa pela aquisição da matéria-prima para produzir vem a simbolizar a origem ou presença do produto na sua forma primaria. A partir daí nasce o elo de ligação entre os estágios da cadeia denominado custo que vai se disseminando no preço do transporte, armazenagem e distribuição (BALLOU - 2006).

À medida que a matéria-prima passa pelos processos de transformação seu deslocamento em transporte permeia a produção do nascimento do produto ao seu período final em todas as partes da cadeia sendo a atividade que absorve o maior percentual em custos logísticos que está entre um e dois terços. A cadeia é composta de produtos de diversas naturezas como:

Industriais destinados a clientes ou empresas que têm o propósito de manipulá-los para a obtenção de outros bens ou serviços, 
Especiais: onde devido ao seu grau de importância em valor o consumidor se predispõe a assumir riscos de eventuais perdas no propósito de adquiri-lo devido a sua raridade o que o torna importante em valor,

Consumo: são destinados exclusivamente ao consumidor final,

Concorrência: os quais o cliente submete-se a fazer uma pesquisa visando a obter um melhor preço frente a qualidade para só então consolidar a compra,

Conveniência: são os bens tangíveis obtidos quotidianamente com pouca confrontação de qualidade ou preço (BALLOU - 2006).

Unitizar tais produtos em sua distribuição é fundamental nos ganhos econômicos da empresa e para isso sua distribuição e manuseio deve passar pelo estudo de espaço e volume objetivando alcançar o maior bloco de carga possível e diminuir a quantidade de deslocamentos de forma que essa estratégia venha a gerar lucros e não custos ao setor logístico (BALLOU - 2006).

A unitização via palete tanto auxilia na movimentação pós produção quanto em distribuição e ganhos de espaços na estocagem ao permitir blocos de cargas mais altos durante seu empilhamento. Portanto medir a relação peso-volume do produto é uma estratégia significativa, à medida que os custos de transporte e armazenagem estão a ele diretamente relacionados (BALLOU - 2006).

O carvão, minério de ferro e enxofre são produtos que fogem ao padrão da unitização de forma que seu deslocamento exige transporte específico a sua natureza física gerando custo na armazenagem além dos cuidados em segurança no seu manuseio. Nesse contexto tais produtos estão inseridos no quesito carga especial.

Carga especial é o produto que foge aos padrões de armazenamento e deslocamento préestabelecidos ao modal de transporte. Equipamentos mecanizados como a empilhadeira para a sua movimentação nos depósitos com capacidade de elevar blocos de carga a mais de 3 metros de altura é de essencial importância tanto para a segurança das equipes de trabalho envolvidas no processo como em questão de custo a sua hospedagem e remoção para o mercado de consumo. Já a utilização de equipamentos mistos como guindaste, trucks industriais e guinchos favorece as empresas em dividendos e celeridade na execução das tarefas (BALLOU - 2006).

Classificar esses produtos em grupos de baixo, médios e alto volumes de venda cria uma rotina de distribuição ao consumidor a partir do seu armazenamento, concebendo assim um nicho especial para cada produto direcionando-os a rota da demanda do cliente onde consumidores que ofertam pedidos em quantidades de alto volume devem ser atendidos diretamente, ficando o atendimento do restante para ser feito a partir de armazéns (BALLOU - 2006).

A armazenagem, e deslocamento de uma pá eólica seguem esses padrões de dificuldade dessa forma fica postulado a meta do trabalho como carga especial onde nosso intuito está em propor por meios de argumentos encontrar uma resolução clara para seus obstáculos em durabilidade, manutenção e transporte não apenas para trazer informação aos leigos nesse assunto, mas também para incentivar debates construtivos entre seus entendedores que venha a contribuir para um melhor desenvolvimento desse maquinário (BALLOU - 2006). 
Tabela 1 - Crescimento de energia eólica (2018/2019)

\begin{tabular}{|c|l|c|c|c|}
\hline Posição & \multicolumn{1}{|c|}{ Estado } & $2019(\mathrm{MWm})$ & $2018(\mathrm{MWm})$ & Diferença \\
\hline 1 o & Bahia & 1.611 & 1.013 & $59,0 \%$ \\
\hline 2 o & Rio Grande do Norte & 1.124 & 1.110 & $1,3 \%$ \\
\hline 3 o & Piauí & 544 & 517 & $5,2 \%$ \\
\hline 4 o & Rio Grande do Sul & 524 & 546 & $-4,1 \%$ \\
\hline 5 o & Ceará & 503 & 505 & $-0,4 \%$ \\
\hline 6 o & Pernambuco & 236 & 248 & $-4,8 \%$ \\
\hline $7 \underline{o}$ & Maranhão & 97 & 75 & $29,8 \%$ \\
\hline 8 o & Paraíba & 49 & 51 & $-4,1 \%$ \\
\hline 9 o & Santa Catarina & 30 & 18 & $67,9 \%$ \\
\hline 10 o & Sergipe & 6 & 8 & $-25,8 \%$ \\
\hline
\end{tabular}

Fonte: CCEE (2019)

Na tabela 1 segundo dados da CCEE (Câmara de Comercialização de Energia Elétrica) o estado da Bahia expressa em números relevantes o valor de $1.611 \mathrm{MW}$ médios em produção no ano de 2019 uma diferença positiva de 59,0\% se comparado com mesmo período em 2018 ocupando a 1a posição seguida do Rio Grande do Norte onde a diferença ao ano anterior foi de 1,3\%. Mas os dados aqui não pressupõe constante domínio apesar da Bahia ter superado o Rio Grande do Norte em número de parques eólico com valores de 160 e 151 respectivamente segundo informações da ABEEólica, em agosto de 2019 já que os avanços em tecnologia aliada a demanda é que vão ditando as regras de posicionamento do ranking.

\section{DESENVOLVIMENTO DA PESQUISA}

0 transporte de pás eólicas, via modal rodoviário incluem um cavalo mecânico $6 \times 2$, um reboque direcional de três eixos e um dispositivo de controle de direção traseiro. Eles têm 68 metros de comprimento e pesam cerca de 45 toneladas além da soma de dificuldade no modal de transporte e a carga a ser deslocada vem o fato de as estradas ainda manterem os mesmos padrões de medidas adotados há 40 anos. Para tanto, os fabricantes de pás ou turbinas eólicas realizam um estudo de viabilidade geométrica (levantamento rodoviário), que detalha as peculiaridades de todas as estradas que serão percorridas por caminhões desde a fábrica de pás até a entrada do parque eólico. Miguel da Cruz explica que, além das adaptações dos conjuntos transportadores, a execução dos transportes, principalmente das pás, resultou em alterações na legislação, tornando-as específicas para o segmento (GUIADOTRC 17/05/2016).

Um possível alento advém de semi-reboques como o Quattro desenvolvido pela empresa inglesa Broshuis capaz de aumentar aproximadamente quatro vezes seu tamanho original viabilizando assim o transporte de pás com extensão de 74 a 80 metros de comprimento. 0 implemento, quando fechado, mede 20,1 metros, mas quando seus quatro extensores são abertos, o comprimento total chega a 69 metros. Além desse sistema de extensão, o implemento pode receber um elevador hidráulico na parte traseira, que levanta a pá eólica a até 10 metros do chão. Esse sistema pode ser usado 
para passar por cima de obstáculos em curvas, como casas, barrancos e até postes (BROSHUIS - 2019).

Durante o deslocamento de uma pá, cada carreta recebe apoio de duas escoltas, ou seja, batedores frontais e traseiros. A função deles é liberar o trânsito da via para a passagem das carretas e impedir que outros veículos as ultrapassem em pistas simples. Todo esse processo está custeando o fabricante e o exportador interno ou externo onde esses valores acabam por serem injetados em todas as partes da cadeia do maquinário visando dessa forma manter o seu ciclo de construção continuamente (ATALNTIC ENERGIAS RENOVAVEIS S.A - 30/04/2019).

O modal rodoviário tem se mostrado a principal opção dos fabricantes já que possui uma peculiaridade que outros meios de transporte não tem ou seja, realizar inúmeros trajetos via terra internamente porém, sua capacidade de transporte é de 1 a 2 pás apenas ao passo que numa balsa oceânica é de 32 acrescente-se a isso a opção da cabotagem e fica evidente que a multimodalidade diminui a distância entre as regiões encurtando o deslocamento do produto em questão. No entanto é um meio de transporte pouco utilizado que poderia vir a contribuir consideravelmente no desenvolvimento do maquinário excluindo dessa forma grande parte dos custos adicionais dentro da logística de escoamento e processos de fabricação (PORTOGENTE -17/04/2017).

Cláudio Ramos, diretor de Projetos Industriais da DHL Global Forwarding Brasil, afirma que, se o transporte de uma pá já é delicado, a experiência no plural tende a ser muito mais desafiadora (Frata - 2019).

Mas ao contrário do aqui postulado o obstáculo desafiador tem sido sua durabilidade uma adversidade ferrenha que vem nos obrigando a injetar consideráveis investimentos em pesquisa seguindo os preceitos que a natureza vem nos impondo ao longo do tempo no intuito de encontrar materiais de maior resistência que venham a lhe dar uma maior durabilidade frente as mudanças climáticas a que ficam expostas constantemente. Feito isso segundo análise da UL DEWI sua rentabilidade pode chegar a ganhos acima de $10 \%$ (O SETOR ELÉTRICO - 2017).

Os reparos e substituições das peças de pás é algo rotineiro ao longo do seu tempo de utilidade além de sua garantia frente ao fabricante ser apenas de 2 a 5 anos e tendo uma durabilidade em torno de duas décadas pressupõe-se prejuízo aos produtores de energia. Porém ao mesmo tempo que custeia também está gerando emprego a seus mantenedores. Sua manutenção não pode ser vista como um reparo simples e sim uma reconstrução do maquinário ao longo do seu tempo de eficácia aja visto sua intensa substituição no decorrer do seu tempo de utilidade. Uma pá opera praticamente 24 horas por dia em condições adversas o que a torna um objeto de avaliação constante sendo que nesse propósito de tempo em uso está a finalidade de manter o custo baixo aos operadores e proprietários. 0 caso contrário, ou seja, a não manutenção seria assumir o custo de um grande reparo isto é a remoção da pá (EPOCANEGOCIOS 12/12/2018).

Sua movimentação nos portos se dá através de caminhões, navios e guindastes especiais além de funcionários com um nível de treinamento diferenciado (DIÁRIO DO NORDESTE - 2017).

No Porto de Pecém em se tratando de deslocamentos a adversidade parece ser um adversário vencido ou fora de combate onde as regras impostas pela natureza foram bem estudadas, assimiladas e convertidas em êxito através de sérios investimentos em 
tecnologia e logísticas voltadas as exigências impostas pela matriz ao longo do seu processo de implantação naquela parte da região. Mas o que fica claro é que esse é um evento que pode ser replicado em outros portos do país o que não vem a ser adequado ou ainda possível em outras partes que compõe a cadeia do maquinário (CEARÁ AGORA - 2019).

Esse êxito de Pecém advêm de uma área específica do seu porto ser modernizada tendo como meta principal as exportações das cargas indivisíveis, ou seja, pás eólicas. Ao longo de 2019 cerca de 2000 pás eólica foram exportadas através do seu complexo industrial e portuário sendo que esse percentual foi três vezes maior que no ano de 2018 onde registrou-se um volume de 683 pás para estados brasileiros além de Estados Unidos e Europa (O ESTADO 27/11/2020).

Segundo José Alcantara Neto Pecém se estruturou, em parceria com os prestadores de serviços operacionais, na contratação de mão de obra especializada e na aquisição de equipamentos no intuito de manusear adequadamente essas peças do descarregamento do pátio de armazenagem até o embarque nos navios.

Possuindo uma área de armazenagem exclusiva para as peças produzidas em seu Complexo Industrial e Portuário do Pecém onde encontram-se instaladas empresas como: wobben wind Power e Aeris Energy Pecém tornou-se um diferencial em relação a outros portos envolvidos nesse processo no país onde de acordo com Alexandre Holanda assistente de Desenvolvimento Logístico a Wobben fabrica suas próprias pás e a Aeris produz para a Vestas e para GE dois grandes players mundiais do setor de energia eólica (GOVERNO DO CEARÁ - 2019).

O Ceará é um exemplo nas exportações desses componentes em 2019 o estado registrou um crescimento em torno de $900 \%$ nas exportações de pás eólicas representando um montante de US\$ 64,9 milhões em equipamentos de acordo com estudo do Centro Internacional de Negócios (CIN) da Federação das Indústrias do Estado do Ceará (Fiec).

0 estado exporta grandes valores para os Estados Unidos seu principal parceiro nesse tipo de equipamento com US\$ 52,8 milhões dos produtos exportados um valor de $730 \%$ se comparado com a demanda dos primeiros meses de 2018 enquanto a Alemanha seu segundo cliente representa US\$12,1 milhões (DIÁRIO DO NORDESTE - 2019).

No primeiro trimestre de 2019 as exportações de pás pelo Complexo Portuário de Pecém com destino ao exterior chegaram a crescer a um percentual de $672 \%$ em similar período de 2018 saltando de 61 peças para 471 segundo dados "Ceará em Comex", do Centro Internacional de Negócios da Federação das Indústrias do Estado do Ceará (Fiec), tornando-se o segundo produto mais exportado da balança comercial cearense (US\$ 48,7 milhões de janeiro a março), um crescimento extenso na movimentação segundo Danilo Serpa (CEO da Cipp/SA) advindo da exploração do potencial competitivo do estado (O POVO - 25/04/2019).

Somando-se a isso a ausência do custeio no deslocamento tornando assim mais acessível o produto e a tecnologia de ponta das empresas instaladas em seu complexo portuário Pecém se tornou alvo do capital estrangeiro e um exemplo a ser seguindo em logística. 
Tabela - 2 Movimentação de pás eólicas para exportação via porto de Pecém (2019).

\begin{tabular}{|l|c|}
\multicolumn{1}{|c|}{ Empresa } & Quantidade \\
\hline WOBBEN & 282 \\
\hline GE & 691 \\
\hline VESTAS & 1.027 \\
\hline
\end{tabular}

Fonte: CIPP (2019).

A tabela 2 traz os valores de pás eólicas movimentadas via exportação no porto de Pecém em 2019 representando um acréscimo 3 vezes maior em relação ao ano de 2018 onde registrou-se um quantia na ordem de 683 pás segundo a CIPP (Complexo Industrial e Portuário do Pecém). Esses valores vem a explicar não só a opção do Brasil pelos serviços desse porto como também a intensa presença de países estrangeiros visto que Pecém os oferece o que outras localidades portuárias ainda estão longe de alcançar ou seja a lógica máxima da logística, a integração dos processos de negócios do usuário final através de fornecedores que fornecem produtos, serviços e informações e agregam valor para os consumidores.

Imagem 1: Semi-reboque da Quattro elevando uma pá eólica

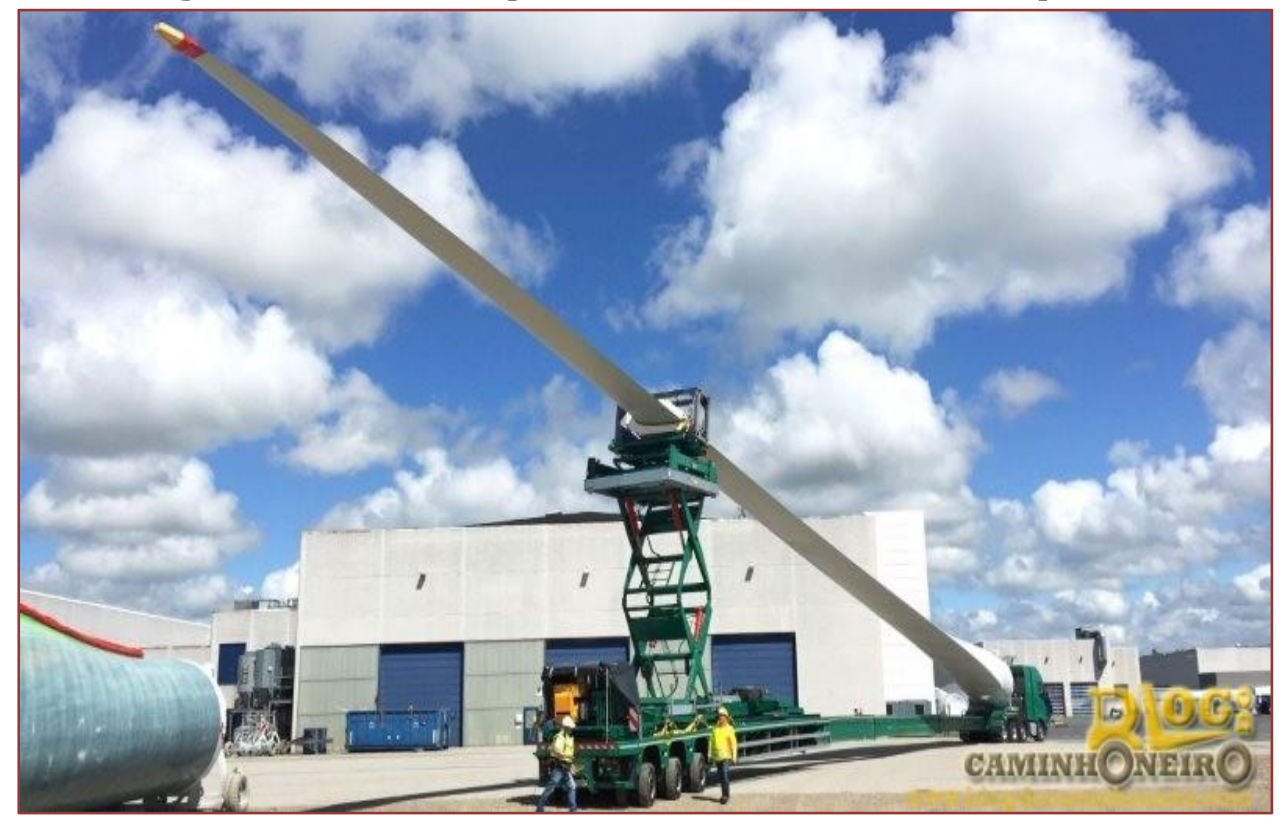

Fonte: Blog do Caminhoneiro (06//02/2019)

\section{RESULTADOS E DISCUSSÃO}

Posto que a matéria- prima da matriz é um fenômeno da natureza a qual não podemos armazenar visto que este método por enquanto está mais próximo da teoria que da realidade investir na natureza não é só um meio de produzi-la mas de mantê-la em abundancia no espaço a que ela pertence. Portanto não se trata apenas de exercitar a busca por uma tecnologia mais condizente com as nossas necessidades, mas de fazê-la seguindo os preceitos que a natureza vem nos impondo. "Se continuarmos desenvolvendo nossa tecnologia sem sabedoria ou prudência, nosso servo pode acabar se tornando nosso carrasco" (OMAR BRADLEY 2015).

Além das dimensões e peso extremamente fora dos padrões de pás e aerogeradores a durabilidade é um obstáculo que vem nos permeando da origem da matriz até hoje caso 
que no mundo tem se mostrado igual a todos os países favorecidos que optaram por esse tipo matriz.

A falta de auxílio do governo em ceder guindastes aos produtores de grandes parques eólicos tem sido um fator a mais a contribuir no custo aja visto que esse tipo de maquinário é de fundamental presença em todos os processos que envolvem o manuseio deste tipo de carga.

O intuito de alimentar a economia nas exportações de pás e aerogeradores não pode ser posto como algo a parte da produção de energia visto que os processos estão separados por motivos diferentes, mas que acabam por chegar ao mesmo propósito.

Na opção de fabricar próximo a área de produção nos leva ao custeamento no escoamento da matéria-prima em questão enquanto ao contrário, ou seja, fabricar o maquinário distante dela nos põe em prejuízo no escoamento do produto final. Posto isso fica evidenciado que por enquanto não apenas o Brasil, mas o mundo por um bom tempo está sujeito ao meio termo nessa questão.

Portanto a partir do momento que temos o conhecimento do tempo de sua durabilidade e estamos constantemente no exercício do êxito satisfatório a armazenagem em local de produção se mostra o ideal no custeio ao deslocamento além de garantir o funcionamento da matriz de forma ininterrupta fazendo com que os investimentos das empresas nos grandes centros consumidores tenham um direcionamento continuo e planejado de forma a manter o desenvolvimento das regiões e do próprio país.

\section{CONSIDERAÇÕES FINAIS}

0 presente trabalho teve como principal objetivo discorrer a respeito do dos mecanismos, características e dificuldades das pás eólicas. Diante das pesquisas e observações realizadas, puderam ser expostos explicitamente os processos pelos quais pás e aerogeradores se tornaram obstáculos consideráveis para os produtores e fabricantes em relação à manutenção, escoamento, produção, e deslocamento no tocante à constante busca por um resultado satisfatório.

Todavia, em face à situação atual, é importante destacar que, ainda com todos os impasses, os investimentos nessa tecnologia trouxeram enorme contribuição para a produção de energia eólica de diversas regiões do país, que, anteriormente, conforme estudado no artigo, eram prejudicadas. Além disso, ganhos significativos foram alcançados mesmo com as dificuldades supracitadas, através de investimentos da esfera pública e privada.

No mais, o trabalho elaborado pôde abordar a relevância dessa tecnologia vinculada à matriz eólica e seus desenvolvimentos e impactos no país, tanto para a evolução e modernização das sociedades, bem como para o surgimento de empregos e para bons resultados aos investidores. 


\section{REFERÊNCIAS}

[1]. Portogente. Como avança a energia eólica no Brasil. 2020 Disponível em: $<$ https://portogente.com.br/noticias/transporte-logistica/112829-como-avanca-a-energiaeolica-no-brasil/> Acessado em: 02 novembro 2020.

[2]. Canalbioenergia. Análise de vida útil permite aumentar tempo de operação de turbinas Disponível em: <//www.canalbioenergia.com.br/analise-de-vida-util-permite-aumentar-tempode-operacao-de-turbinas-eolicas/> Acessado em: 02 novembro 2020.

[3]. BBC. Série de entraves limita o uso da energia eólica no Brasil. 2013 Disponível em: <https://www.bbc.com/portuguese/noticias/2013/06/130604_energia_eolica_mdb/> Acessado em: 02 novembro 2020.

[4]. Portalsaofrancisco. Energia eólica. 2015 Disponível em: <https://www.portalsaofrancisco.com.br/geografia/energia-eolica/> Acessado em: 02 novembro 2020.

[5]. CRN-BIO. Energia eólica garante crescimento sustentável. 2017 Disponível em: pelosventos/>. <https://crnbio.com.br/regioes-nordeste-e-sul-se-destacam-na-geracao-de-energiagerada- Acesso em 02 novembro 2020.

[6]. Cearaagora. Ceara-e-o-principal-estado-exportador-de-pas-eolicas-do país. 2019 Disponível em: <https://cearaagora.com.br/ceara-e-o-principal-estado-exportador-de-paseolicas-do-pais/>

[7]. AECWEB. Transporte de cargas especiais adota logística desafiadora. 2019 Disponível em: <https://www.aecweb.com.br/revista/materias/transporte-de-cargas-especiais-adotalogistica-desafiadora/13398/> Acesso em 02 novembro 2020. Veio do desenvolvimento

[8]. ATRBRASIL. Empresa europeia desenvolve pás eólicas implemento especial para transporte de. 2019 Disponível em:

$<$ http://atrbrasil.com.br/integra.asp?id=30084\&titulo=Not\%C3\%ADcias/>

[9]. Epocanegocio Como é feita a munutenção de turbinas eólicas 2018 Disponivel em : <https://epocanegocios.globo.com/Caminhos-para-o-futuro/Energia/noticia/2018/12/como-efeita-manutencao-das-turbinas-eolicas.html/>

[10]. ATLANTICENERGIA. Saiba como é realizado o transporte de pás eólicas. 2019 Disponível em: <http://atlanticenergias.com.br/saiba-como-e-realizado-o-transporte-de-pas-eolicas/>. Acesso em 02 de novembro 2020.

[11]. Frata. Vestas e DHL firmam firmam parceria para exportação de pás eólicas no Brasil. 2019 Disponível em: <https://frata.com.br/en/vestas-e-dhl-firmam-parceria-para-exportacaode-pas-eolicas-no-

brasil/\#: :text=Cl\%C3\%A1udio\%20Ramos\%2C\%20diretor\%20de\%20Projetos,a\%20ser\%20m uito $\% 20$ mais $\% 20$ desafiadora.\&text=No $\% 20$ trajeto $\% 20$ do $\% 20$ transporte $\% 20$ das,ainda $\% 20$ mai s\%20o\%20trabalho\%20realizado/>. Acesso em 02 de novembro.

[12]. Somaticaeducar. Manutenção eólica. 2020 Disponível em:

<http://www.somaticaeducar.com.br/manutencao-eolica/> Acesso em: 02 novembro 2020.

[13]. Folhape. Suape ganha fábrica da SIW Kits Eólicos. 2019 Disponível em : <https://www.folhape.com.br/economia/suape-ganha-fabrica-da-siw-kits-eolicos/125714/> Acesso em: 02 de novembro 2020.

[14]. Ceara. Porto de Pecém triplica exportação de pás eólica 2019 Disponível em: <https://www.ceara.gov.br/2019/12/23/porto-do-pecem-triplica-movimentacao-de-paseolicas-em-2019/> Acesso em: 02 novembro 2020. 
[15]. Diário do Nordeste. Ceará registra quase 900\% em exportações de pás eólicas. 2019 Disponível em: <https://diariodonordeste.verdesmares.com.br/negocios/ceara-registra-alta-dequase-900-em-exportacao-de-pas-eolicas-1.2106768/> Acesso em: 02 novembro 2020.

[16]. Opovo. Exportações de pás eólicas cresce 6 vezes no Ceará. 2019 Disponível em: <https://www.opovo.com.br/jornal/politica/2019/04/20/exportacao-de-pas-eolicas-cresceseis-vezes-no-ceara.htm/> Acesso em: 02 novembro 2020.

[17]. Tecmundo. 20 Citações inspiradoras sobre tecnologia que farão você refleti. 2015 Disponível em: <https://www.tecmundo.com.br/tecnologia/78538-20-citacoes-inspiradorastecnologia-voce-refletir.htm/> Acessado em: 02 novembro 2020.

[18]. Blogdocaminhoneiro. Empresa europeia desenvolve implemento especial para transporte de pás eólicas. 2019 Disponível em: < https://blogdocaminhoneiro.com/2019/02/empresa-europeia-desenvolve-implementoespecial-para-transporte-de-pas-eolicas/>

[19]. Broshuis. Sistemas de levantamento de deslizamento 2021 Disponível em <https://www.broshuis.com/innovations/lifting-and-sliding-system/> Acesso em: 20 novembro 2021.

[20]. Broshuis Reboque de quatro laminas de 3 eixos 2021 Disponível em: https://www.broshuis.com/products/flat-trailer/wind-turbine-trailer/3-axle-quatro-bladetrailer/ Acesso em: 20 novembro 2021. 


\section{Capítulo 14}

\section{A importação da soda cáustica dentro do Porto de Santos e os riscos da sua movimentação}

\section{Ariane de Lima Monteiro \\ Marcos Pissarra Bahia}

Resumo: 0 hidróxido de sódio em solução aquosa (lixívia de soda cáustica), que diferente de forma sólida, no primeiro semestre movimentou em valores FOB o valor de $\mathrm{R} \$ 193.734 .621,00$ e o cais santista moveu deste total a faixa de $\mathrm{R} \$ 35.548 .721,00$. Tendo a operação no porto de Santos feita pelo terminal Dow Química, que segundo Agência Nacional de Transporte Aquaviário - ANTAQ, possui um comprimento de píer de 30 metros com 5 dolfins de amarração, tem a carga de soda cáustica como seu principal granel movimentado. E conforme apurado, a natureza da carga é de origem de importação, como os Estados Unidos sendo o maior fornecedor ao mercado nacional. Contudo, a soda cáustica possui uma classificação de carga perigosa e por tal, necessita de cuidados desde o seu descarregamento até o seu transporte por vias rodoviárias, onde essa, nos últimos anos vem tendo um acréscimo em relação a acidentes e derramamento em rodovias.

Palavras-chave: Soda Cáustica. Porto de Santos. Carga Perigosa. 


\section{INTRODUÇÃO}

Dados extraídos do portal de Estatísticas de Comércio Exterior - Comex Stat (2020) a importação do Hidróxido de sódio (soda cáustica) em forma sólida foi equivalente a U\$ 5.558.207,00 nos seis primeiros meses do ano, o porto de Santos foi responsável pelo valor de U\$ 1.335.044,00 deste montante. Contudo, essa carga pode ser movimentada além disso em forma líquida onde temos o Hidróxido de sódio em solução aquosa (lixívia de soda cáustica), que diferente da forma sólida, no primeiro semestre movimentou em valores FOB o valor de $\mathrm{R} \$ 193.734 .621,00$ e o cais santista moveu deste total a faixa de $\mathrm{R} \$$ 35.548.721,00. Tendo a operação no cais santista pelo terminal Dow Química, na margem direita do porto a soda caustica em forma líquida tem a sua operação centralizada e rigorosa afim de garantir os padrões estabelecidos tanto pelas autoridades do porto, quanto as locais. 0 enlevo deste granel líquido é disposto a caminhões tanque que utilizam do modal rodoviário para essa fase deste processo logístico que deve seguir normas estipuladas pela Agência Nacional de Trânsito Terrestre -ANTT e o Conselho Nacional de Trânsito - CONTRAN. Entretanto acidentes no modal rodoviário onde veículos que transportam cargas de natureza perigosa obtém uma relevância a parte, pois diante deste acontecimentos, a intensidade do risco está constantemente associada ao grau de periculosidade do material transportado e o seu potencial causador de danos ao meio ambiente e à saúde de pessoas que por ventura vierem a serem expostas. Conforme indica a Confederação Nacional De Transportes CNT (2019) o modal rodoviário concentra cerca de $61,1 \%$ do volume de cargas transportadas no Brasil, e esse percentual almeja a crescimento tendo em uma visão o grande aumento do comércio entre os países da latinos, no entanto, o conjunto infra estrutural das rodovias brasileiras, e a evidente precariedade da frota de transportadores de cargas, e diversos outros fatores, beneficiam o aumento de casos acidentais, compondo-se em um agravante problema para o bem-estar público. (IPEA,2019).

No Brasil, estatísticas mostram que de 1 a $4 \%$ das queimaduras são provocadas por agentes químicos, sendo a soda cáustica um dos principais causadores deste tipo de queimadura (MASSOLI,2019). Por tanto é fundamental entender as peculiaridades do transporte de cargas perigosas e como deve ser o transporte, devido que acidentes graves apontam uma tendência de crescimento nas estradas brasileiras, de acordo com a CNT (2018). E em conformidade com a CNT, o portal de notícias G1 (2019) apontou com dados oriundos da Companhia Ambiental do Estado de São Paulo - CETESB que apenas em Campinas (SP) a média de acidentes é de 23 ocorrências por mês. E o grande risco deste material é a sua alta periculosidade que em contato com superfícies como a pele humana, causa queimaduras graves e se inalado o dano as vias aéreas é extremo segundo apontam Hospital das Clínicas da Faculdade de Medicina de Botucatu - HCFMB.

A metodologia é o centro de uma pesquisa, onde que a mesma se posiciona diretamente no âmbito em que irá acertar o seu direcionamento, pois como indica Gil (2008), a pesquisa tem como fundamento a ciência, já que ela busca a veracidade de fatos e definem as sequências ou métodos que irão se seguir, sejam esses por induções, observação ou experimentos. Prodanov (2013) enfatiza que a pesquisa científica é toda uma preparação de uma análise regrada de um método que se abordam características investigativas onde a finalidade é a intenção de explanar as questões mediante as práticas metodológicas de processos podendo esses serem rotulados em vertentes como revisão bibliográfica a qual busca e utiliza dados de estudos previamente publicados. 
Métodos qualitativos que deduzem o estudo em meios para que necessitem representar informações sobre determinados grupos ou indivíduos. Pesquisa quantitativa em que a sua natureza visa os dados e estatísticas sobre temas e áreas que carecem de representações gráficas ou numéricas de fenômenos sociais. Pesquisa exploratória possuindo objetivos de aprimoramento de conceitos, busca de informações e soluções de problemas, e a pesquisa descritiva a qual dá ao pesquisador caminhos para que se possa observar, anotar, e levar em consideração as realizações da interpretação dos fenômenos estudados, através de artifícios de proveito de dados. Portanto, os desígnios propostos para este artigo é corroborar estudos de cunhos bibliográficos introduzidos de conteúdos científicos já de antemão apresentados por instituições, que irá servir de alicerce e referenciação para a natureza exploratória da pesquisa apresentada.

\section{FUNDAMENTAÇÃO TEÓRICA}

De acordo com a Associação Brasileira da Indústria do Cloro Álcalis e Derivados ABICLOR, a soda cáustica é obtida por eletrólise que conforme aponta Braga (2009) Eletrólise é uma reação não espontânea provocada pelo fornecimento de energia elétrica, proveniente de um gerador) da salmoura (solução concentrada de cloreto de sódio em água) tornando assim livre de impurezas que inutilizam a eficiência e o proveito do método produtivo. Involuntariamente ao procedimento, a soda cáustica oferece-se sob a forma de solução aquosa, nítida, contendo ao que se tem em média cerca de $50 \%$ de hidróxido de sódio $(\mathrm{NaOH})$ em peso.

\subsection{CADEIA DE SUPRIMENTOS: SODA CÁUSTICA}

Segundo Bowersox e Closs (2001), cadeia de suprimento é uma junção estrutural das operações e fornecedores, ao qual alinhados entregam produtos ou serviços a consumidores. E ao se referir as operações de uma cadeia de suprimentos, Ballou (2006) descreve que as informações e os processamentos dos pedidos é vital para a gerencia desta cadeia. Com isso, seguindo as informações desses autores entende-se que é necessário um estudo aprimorado sobre a cadeia.

Conforme exposto na figura 1, o resultado da reação química para a obtenção do composto cáustico, expõe que o efeito do processo faz com que ocorra a geração de mais compostos, sendo esses ambos utilizados em quase sua maioria como materiais bases para indústrias. Entretanto as aplicações se diferem, devido ao cloro possuir a característica de um produto extremamente tóxico e se oferece em estado gasoso aumentando ainda mais a sua gravidade, já o hidróxido de sódio ou a soda cáustica apresentasse em forma aquosa. 
Figura 1: Processo de Eletrólise da Soda Cáustica

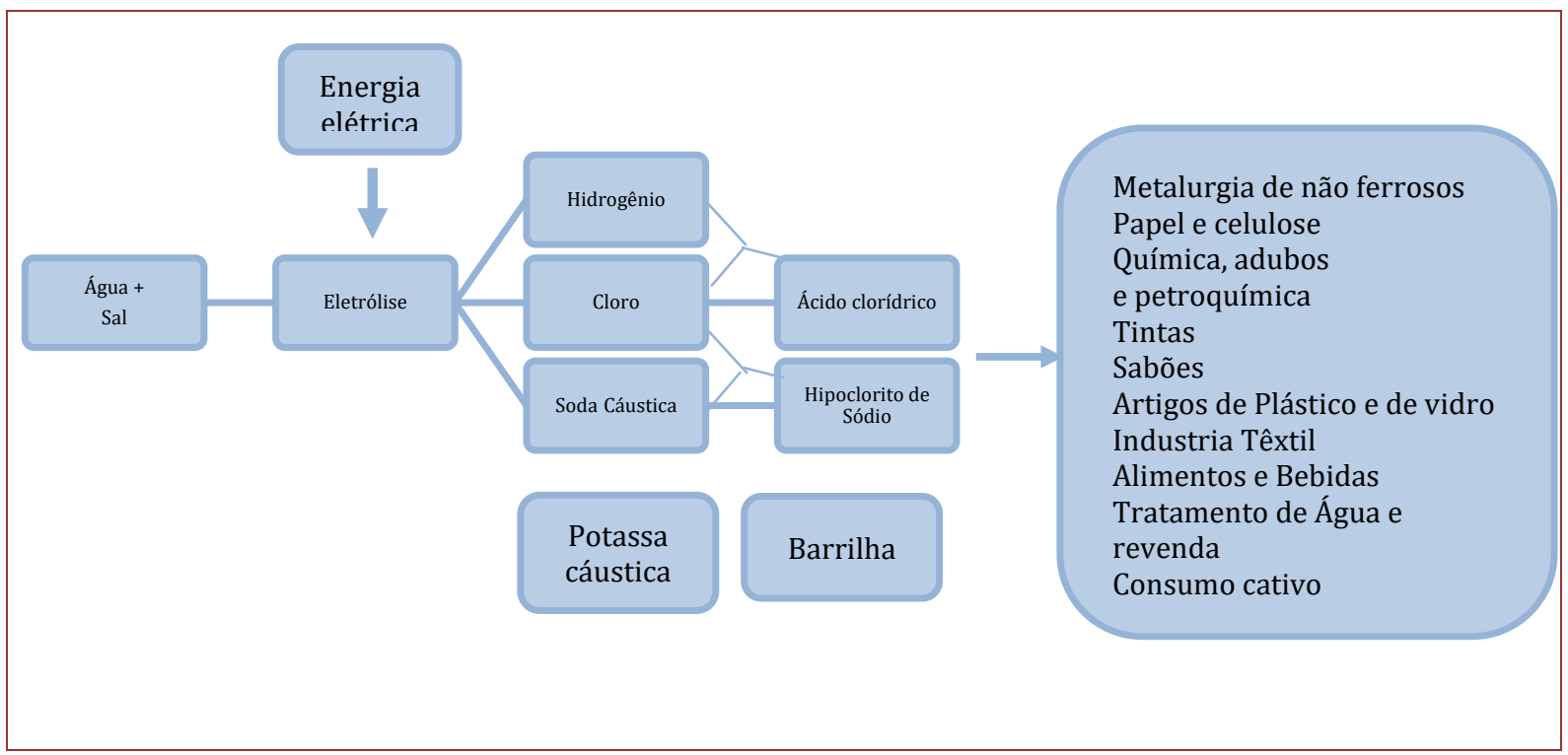

Fonte: Fernandes et All (2009)

0 processo acima pode ser explicado através da fórmula química disposta, que denota as substâncias possíveis de extração com a eletrólise do CLORETO DE SÓDIO.

Figura 2: Fórmula soda cáustica

$$
\begin{gathered}
2 \mathrm{NaCl}+2 \mathrm{H}_{2} \mathrm{O} \rightarrow 2 \mathrm{NaOH}+\mathrm{Cl}_{2}+\mathrm{H}_{2} \\
2 \mathrm{Al}+2 \mathrm{NaOH}+2 \mathrm{H}_{2} \mathrm{O} \rightarrow 2 \mathrm{NaAlO}_{2}+3 \mathrm{H}_{2}
\end{gathered}
$$

Fonte: adaptado pelos autores

\subsection{ARMAZENAMENTO E COMERCIALIZAÇÃO}

O seu armazenamento deve ocorrer em compartimentos capazes de assegurar a sua estanqueidade, pois por ser um solvente, e ainda ser comercializado em sua forma líquida. A soda cáustica necessita de tanque calandrado, ou tanques de polímeros que suportem o seu grau ácido de solvência, o uso de paletes de contenção favorece na absorção do líquido em situações de vazamento ou danificações ao tanque. Todo o processo de armazenagem necessita de aval de órgãos municipais e principalmente estaduais. Seguindo sempre a NR 20.1.1 correspondente ao armazenamento de solvente e produto químico, conforme a Universidade Federal de Viçosa - UFV, expõe a obrigatoriedade de que o armazenamento possua um sistema de ventilação, sinalização, equipamentos de proteção - EPIs e a área de administração separada da área de armazenagem. 
Figura 3: Tanque de armazenamento da soda cáustica

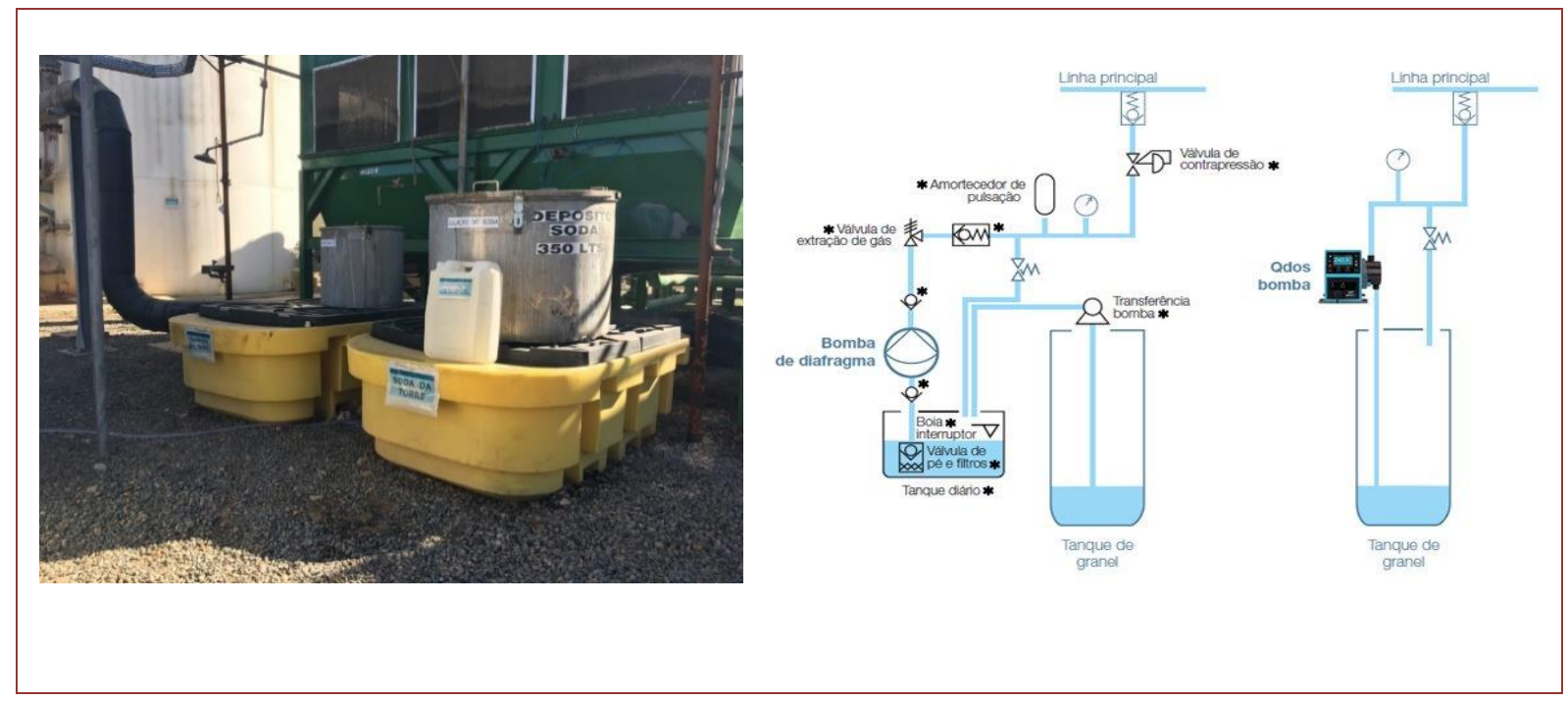

Fonte: TECNOTRI

A sua comercialização após estes processos se dá em sua maioria na forma a granel líquida onde o seu transporte se realiza em caminhões tanque e tambores devidamente vedados e adequados a este transporte seguindo as normas da ANTT a qual passa-se a ser considerada como uma carga especial de cunho perigoso.

Figura 4: Carregamento de Caminhão Tanque com Soda Cáustica

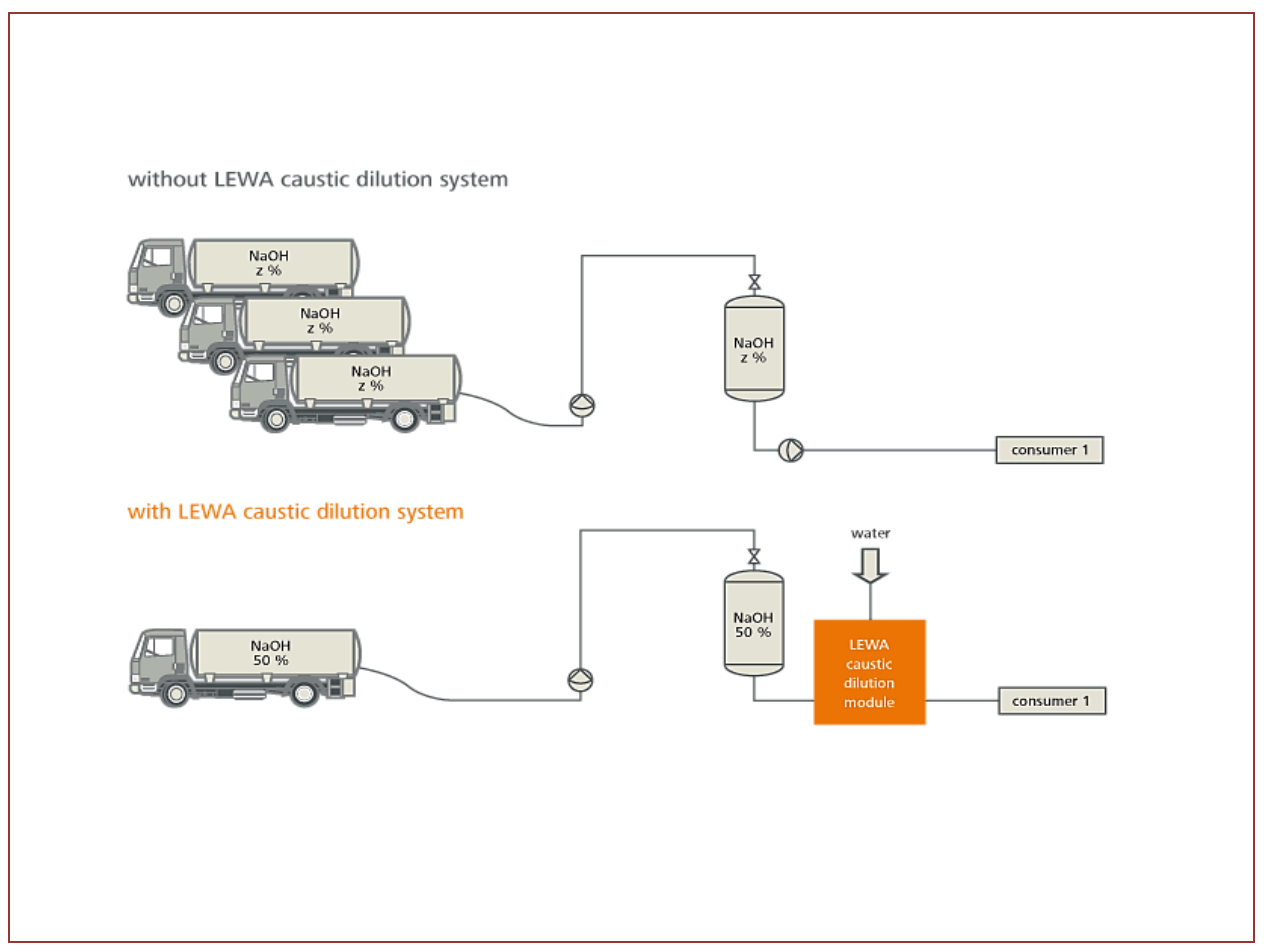

Fonte: LEWA 
A soda cáustica é comercializa em duas maneiras, para a indústria de transformação, a sua venda é realizada na forma pura, ou seja sem a diluição por água. Já por consumidores finais, e que terão o uso deste material para limpeza, solvência de outros materiais, a soda é comercializada em tambores ou recipientes contenfores de pouca capacidade, mas essa soda cáustica é diluída 50\% em água, para que o seu grau de periculosidade seja amenizado.

Figura 4: Embalagens unitizadas

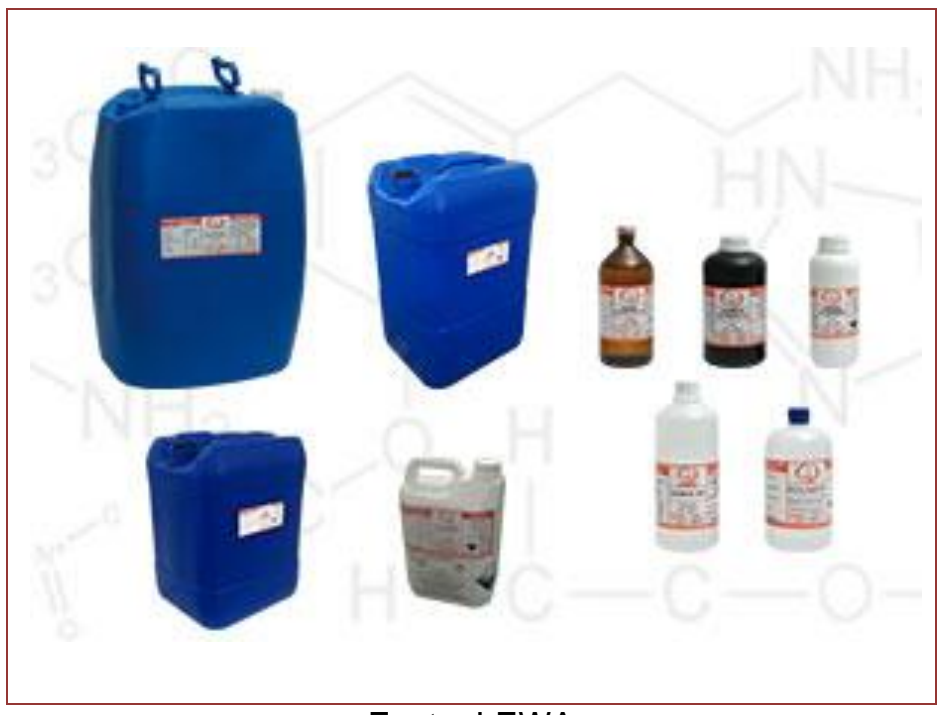

Fonte: LEWA

Produtos contentores de reagentes químicos, carecem de uma adequada padronização, que segundo BRASKEM (2020), favorece a sua identificação em casos de acidentes ou vazamentos. O Ministério da Agricultura e Abastecimento - MAPA, através da instrução Normativa 53/2013, as normas e parâmetros para que se siga-se um padrão de identificação, onde contenha o estabelecimento fabricante, o grau de periculosidade do material, o seu nível de solvência e o seu neutralizante para os casos de ações mais graves.

\subsection{CARACTERÍSTICAS PARA A MOVIMENTAÇÃO DA SODA CÁUSTICA}

0 transporte de produtos IMO requer as demandas impostas para a classe ou a subclasse, ponderando os respectivos arrojos e os critérios já estabelecidos da classificação. 0 produto perigos recebe um número $\mathrm{ONU}$, que serve para a sua identificação internacional. Tal número funciona como se fosse uma categoria de RG que claramente o assemelha a um produto perigos. A sua composição é por quatro dígitos, tendo o hidróxido de sódio o - noํ. ONU 1824, este número de série estabelece o grau de gravidade a vida e ao ambiente que ele possa vir a ser exposto. 
Figura 5: Número ONU para produtos IMO

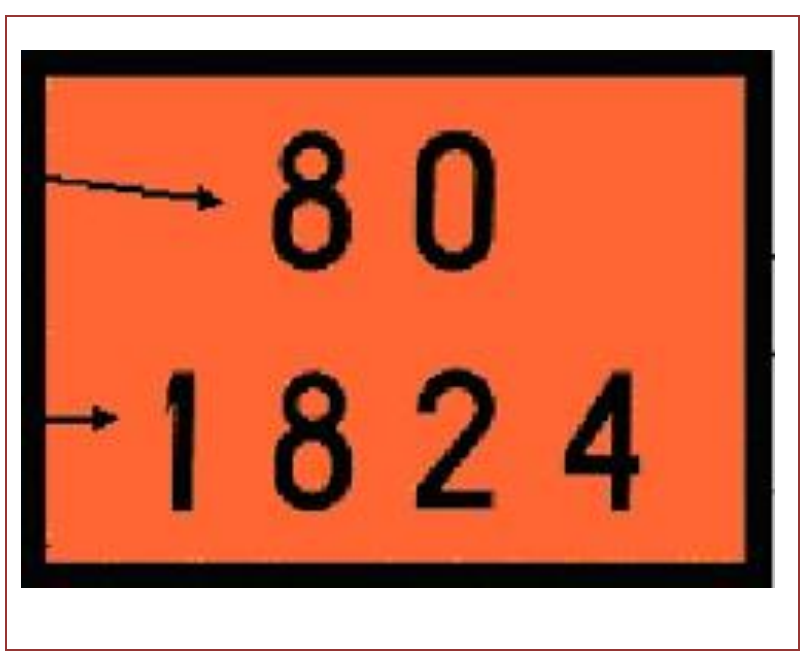

Fonte: DNIT

Figura 6: Sinalização no caminhão tanque

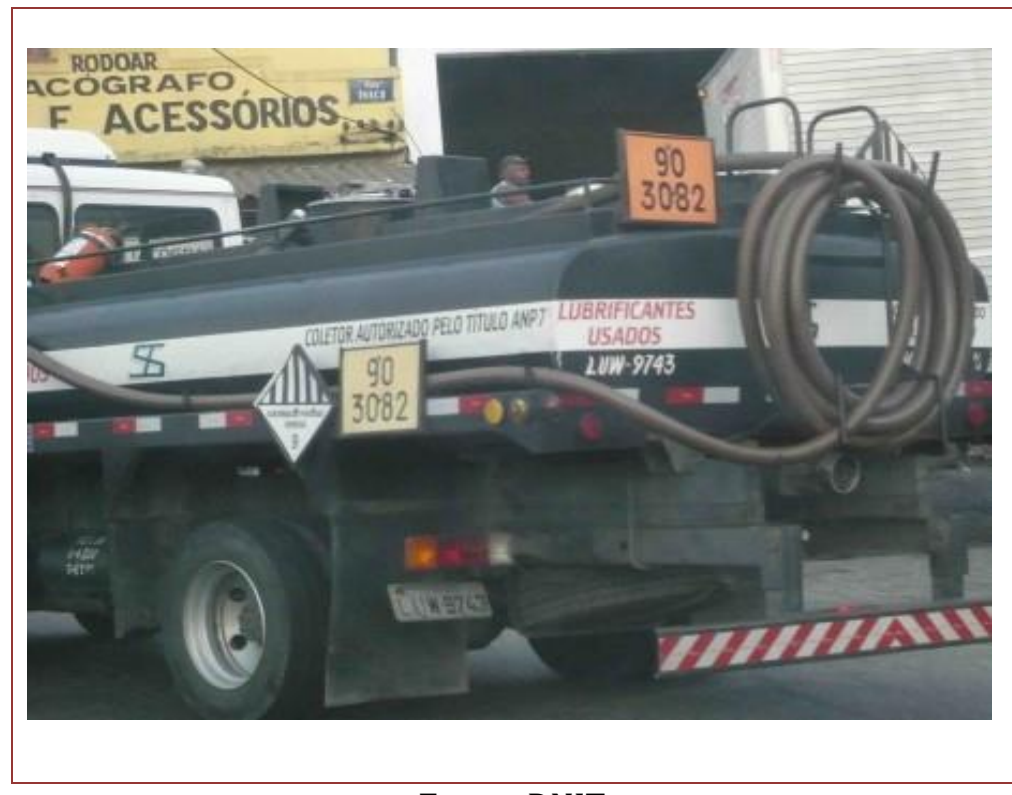

Fonte: DNIT

Na figura 5, apresenta-se a numeração que é exigida para o transporte de tais cargas, essa padronização favorece para que a carga possa ser reconhecida em casos de imprevistos, e conforme a resolução da ANTT no 5.232, a disposição da placa deve ter ao menos duas colocações, sendo uma fundamental na parte traseira e outra podendo ser nas laterais do veículo transportador da carga, como é disposta na figura 6.

As empresas são envolvidas com os transportes de cargas perigosas seja ela de origem importação ou exportação, precisará usar embalagens de armazenamento bem construídos e que mitiguem desastres ambientais. Isso se torna muito importante, especialmente se o material que você está transportando for tóxico ou volátil por natureza. Produtos Perigosos devem ser acondicionados em embalagens homologadas, com garantia de qualidade e resistentes para suportar os choques e as operações de transporte. 
A ANTT é o principal órgão condutor de regulamentações do transporte rodoviário no Brasil. Em referência a isso, a movimentação por esse modal segue as regras previstas pela agência, e no caso do enlevo de cargas perigosas cabe a ANTT a responsabilidade de classificar os produtos seguindo as parametrizações apresentadas pela ONU e, a documentação burocrática para avaliza dos atos regulamentários.

Para o transporte aquaviário deste tipo de mercadoria, a competência passa a ser da ANTAQ, onde o artigo 23 da Lei 10.233/01, estabelecem a esfera de ação da ANTAQ o transporte aquaviário de cargas especiais e perigosas e o artigo 27 da própria lei constitui que cabe à ANTAQ colocar padrões e métodos às operações de transporte aquaviário dessas cargas perigosas.

\subsection{CARGAS PERIGOSAS}

A ANTAQ, define que cargas perigosas são aquelas com características explosivas, como os gases comprimidos ou liquefeitos, inflamáveis, oxidantes, venenosas, infecciosas, radioativas, corrosivas ou poluentes, e que por ventura possam vir a oferecer danos prejudiciais tanto a pessoas quanto a instalações em ambientes gerais. O Departamento Nacional de Infraestrutura de Transportes - DNIT, órgão responsável pela base de transportes no país, impõe que as mercadorias de caráter perigosa são todas aquelas de origem química, biológica ou radiológica e que possa levar lesividade ao meio ambiente, à população e aos seus bens. Carga especial de categoria indivisível, superdimensionada ou pesada é a carga que não pode, sem custos indevidos ou risco de danos, ser dividida em duas ou mais partes e que, para fins de transporte, excede o peso e/ou dimensões dos veículos convencionais, conforme definidos pela resolução 210/06 do Conselho Nacional de Trânsito - CONTRAN.

\subsubsection{IMO}

IMO (International Maritime Organization) é a agência especializada das Nações Unidas responsável pela segurança e proteção dos navios e pela prevenção da poluição marinha e atmosférica por navios.

0 transporte de produtos IMO é regulamento pelo incluso de uma diretriz estabelecida pelo Subcomitê de Especialistas das Nações Unidas (ONU) que constitui parâmetros para o transporte de mercadorias perigosas. As diretrizes são internacionais e sólidas para impedir imprevistos ou danos a pessoas, bens e meio ambiente.

Para os produtos considerados perigosos é adotada uma base no tipo de risco que poderão vir a apresentar de acordo com as Recomendações para o Transporte de Produtos Perigosos das Nações Unidas e de concordata a esse modelo há uma classificação na qual os transportadores desta natureza de carga devem seguir. 
Tabela 1: Produtos de natureza Perigosa

\begin{tabular}{|c|l|}
\hline CLASSE & \multicolumn{2}{c|}{ NATUREZA } \\
\hline 1 & Explosivos \\
\hline 2 & Gases \\
\hline 3 & Líquidos inflamáveis \\
\hline 4 & Sólidos inflamáveis \\
\hline 5 & Substâncias combustíveis e materiais oxidantes \\
\hline 6 & Substâncias tóxicas (venenosas) e infecciosas \\
\hline 7 & Materiais radioativos \\
\hline 8 & Corrosivos \\
\hline 9 & Mercadorias perigosas diversas \\
\hline
\end{tabular}

Fonte: DNIT

\subsection{HIDRÓXIDO DE SÓDIO - SODA CÁUSTICA / NaOH}

O hidróxido de sódio é um reagente ativo para a produção de múltiplos produtos químicos orgânicos, esse material destaca-se em seus principais aproveitamentos o branqueamento de papel e celulose, no uso da indústria química e petroquímica, metalurgia, sabão e detergentes, indústria têxtil e de alimentos. A sua origem denota de forma natural, e carrega um relevante papel na cautela perante a poluição e no trato de efluentes, seu uso na indústria química viabiliza esses processos industriais, que com uso destes álcalis a outros agentes químicos, proporciona a criação ou transformação de outras substâncias.

Gráfico 1: Aplicação da Soda Cáustica como matéria prima, adaptado de ABICLOR

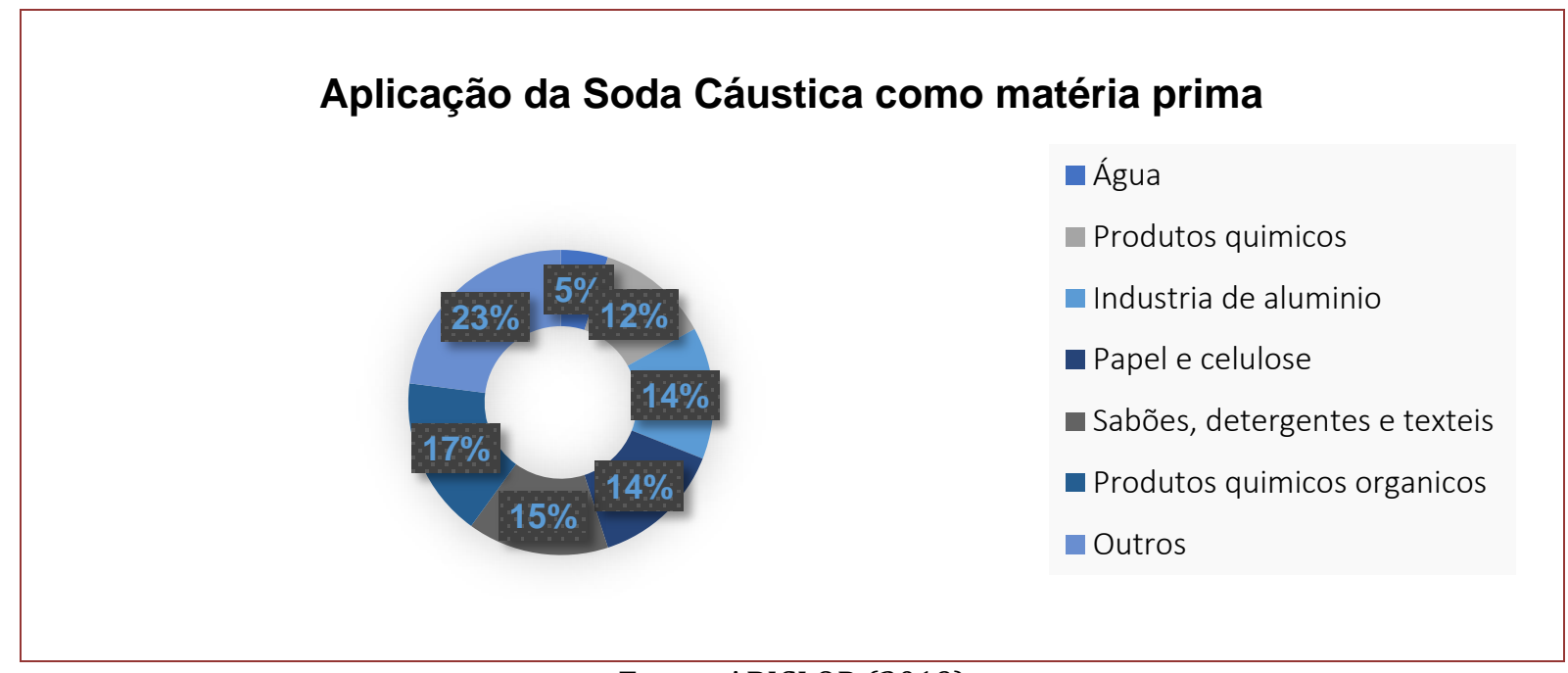

Fonte: ABICLOR (2019)

O uso em indústrias de petróleo e gás natural segundo aponta a ABICLOR (2019) destina-se para remoção de materiais ácidos de queima dos hidrocarbonetos e gases. Já no campo da indústria têxtil, é empregado para recurso de tratamento químico do algodão e o tingimento de fibras provenientes de natureza sintética. Entretanto, a grande parte do setor consumidor de soda cáustica é a indústria de celulose e papel, que utilizam para os processos de polpação e branqueamento, por fim, se tem o consumo de soda cáustica para o refino da alumina, que se equivale a $11 \%$ da demanda global, sendo este uso o responsável por demandar mais da metade de toda a soda cáustica global. 


\section{DESENVOLVIMENTO DA PESQUISA}

O objetivo geral é a avaliação perante a chegada da Soda Cáustica importada pelo porto de Santos apoiando-se a sobre a necessidade da demanda interna, que depende da importação para suprir o mercado de brasileiro devido a insuficiência da produção desta carga em território nacional. Entretanto, busca-se como um precavido objetivo específico salientar sobre os perigos de transporte da soda cáustica sejam esses em sua maioria por vias rodoviárias, deixando claro a inópia de planos de mitigação dado a natureza originária da carga, sendo essa classificada como carga perigosa. Será apresentado planos de logística de transporte restrita que seguirão as regras e regulamentos impostas por órgãos federais, buscando anteparo a situações de acidentes, a qual por exemplo o derramamento em vias rodoviárias que levam a ocorrer vazamentos da substância em solo, e geram impactos sobre a saúde humana e o meio ambiente (contaminação de águas superficiais e subterrâneas, ar e cadeia alimentar).

\subsection{MOVIMENTAÇÃO NO PORTO DE SANTOS}

Segundo aponta dados extraídos dos serviços de análises e estatísticas da ANTAQ. Tendo um comprimento de píer de 30 metros com 5 dolfins de amarração, que conforme aponta a ANTAQ (2009), dolfim de amarração é uma estrutura de concreto fincada ao mar que vai até a superfície, facilitando assim a amarração de navios. Sua localização se dá na área do porto organizado na região de margem do Guarujá.

Figura 7: Visão aérea do terminal da DOW QUÍMICA

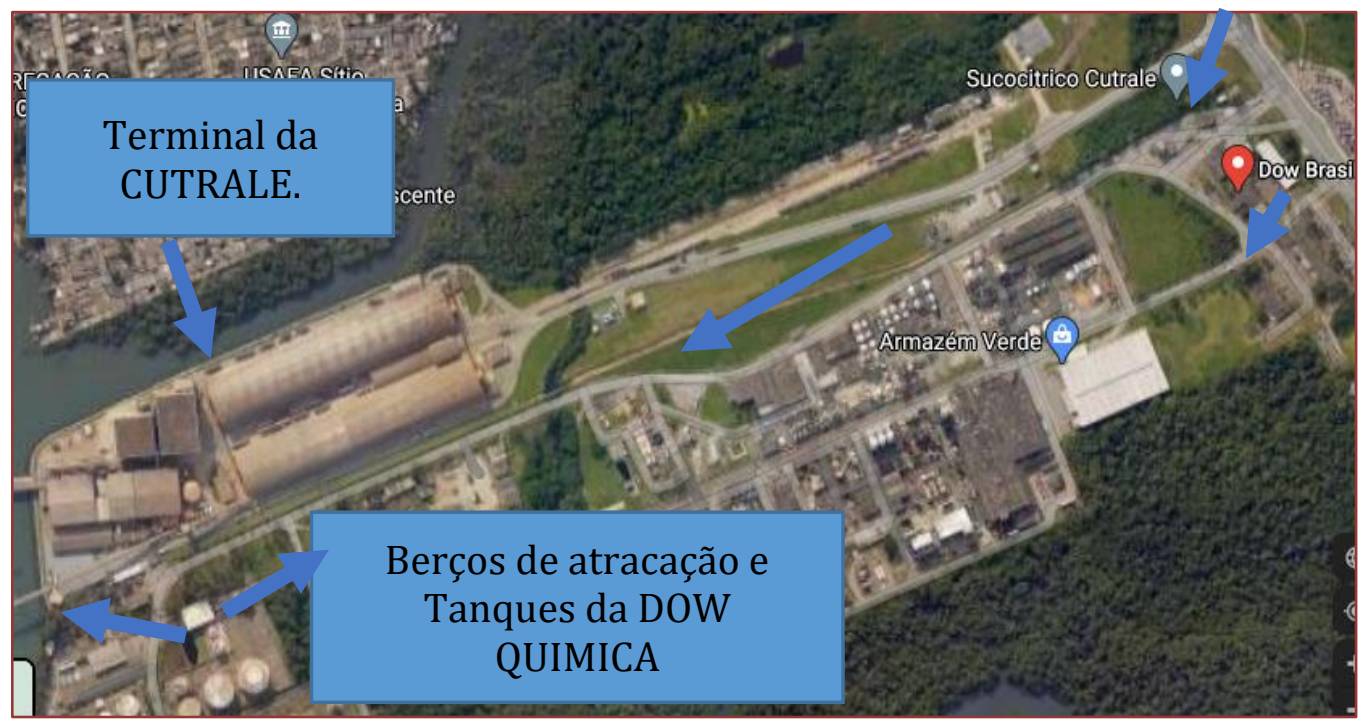

Fonte: GOOGLE MAPS

Ressaltando a figura 7 a estrutura logística disposta pela Dow Química, faz com que o caminhão tanque quer irá realizar o transporte da soda cáustica, entre e percorra um caminho a qual leva para os tanques de armazenagem da empresa. Após esse processo, o caminho se dá no retorno a Av. Santos Dumont, que possui ligamento com a SP 238, a qual é usada em primeira etapa para a leva deste produto a outro ponto de produção que se localiza na cidade de Cubatão, que segundo a própria empresa, após a coleta de informações apontou que a industrialização da soda cáustica se realiza, podendo ser transformada em produto sólido, ou refinada em líquido, para que assim possa ocorrer a 
distribuição para as demais áreas, tendo o vale do aço como o principal requerente da carga.

Em conformidade com a ANTAQ, no primeiro semestre do ano, a Dow Química operou 82.523 milhões de toneladas de carga, e sendo a Soda Cáustica o granel mais movimentado.

Gráfico 2: Importação de Soda Cáustica pelo Terminal Dow Química

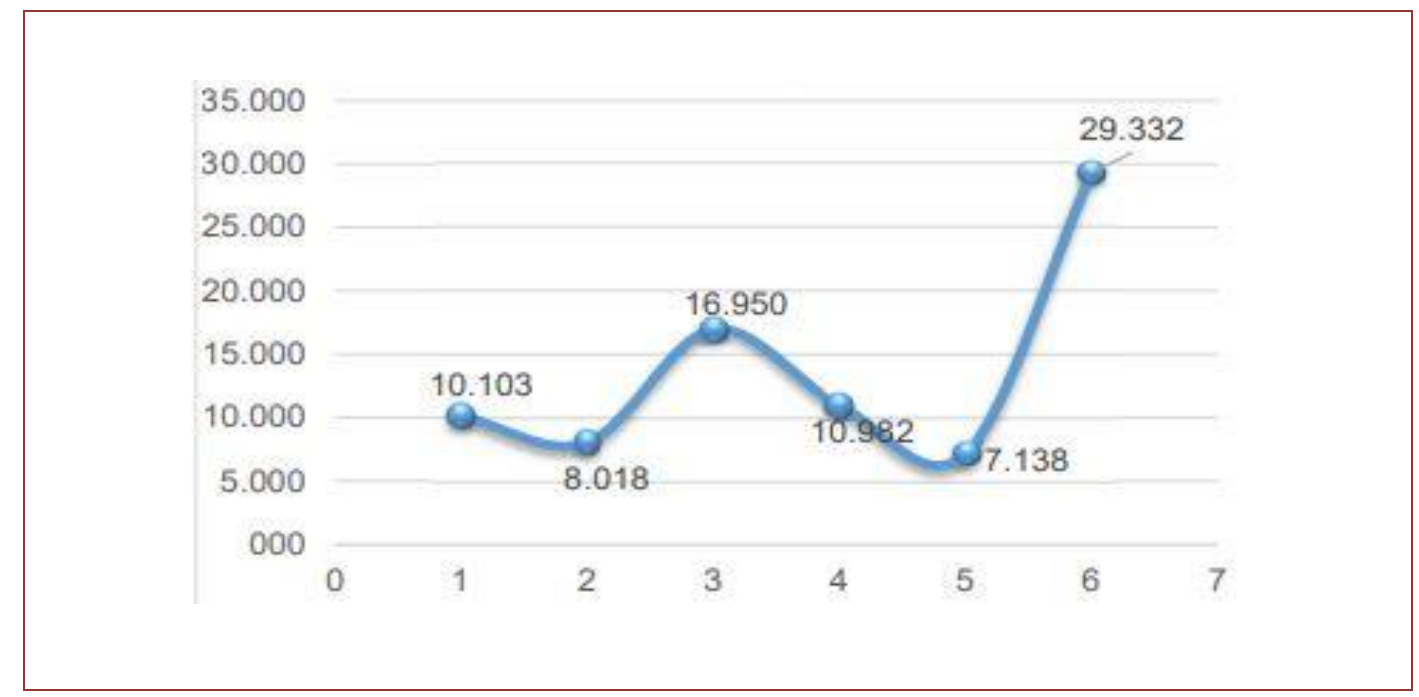

Fonte: ANTAQ

Dados do WEB PORTOS (2020) expostos no gráfico 3 a seguir, evidenciam a evolução anual da movimentação da carga total do terminal, e demonstra que o ramo principal de origem da carga é de importação, dada a clara consistência da insuficiência da oferta deste tipo de mercadoria no comércio interno. 0 fato interessante é que nos anos de 2015, 2016 e 2017 os valores exportados foram zero, muito por conta da recessão econômica que afetou todo o mercado e os seus segmentos.

Gráfico 3: Evolução Anual da Dow Química no Porto de Santos

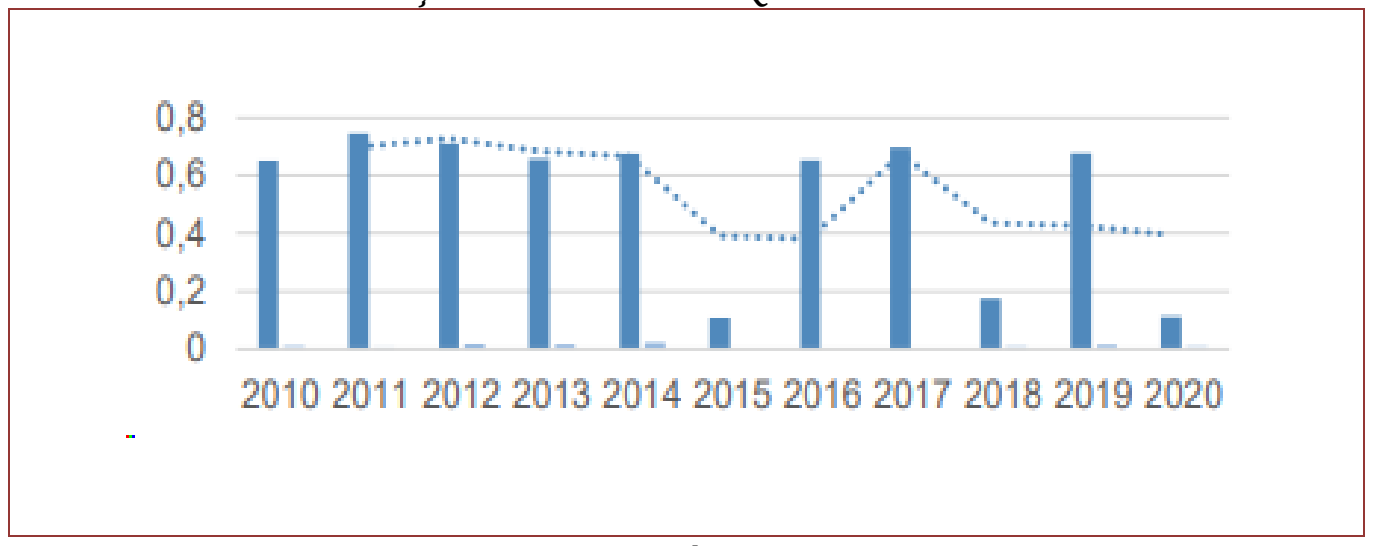

Fonte: Web Portos

De acordo com Trade Statistics for International Business Development - TRADE MAP (2019), os maiores países fornecedores da soda cáustica ao Brasil, foram os Estados Unidos com 2.302.616 toneladas, em segundo o Peru com 2.182.886 toneladas e pôr fim a Argentina com 73.354. 


\subsection{TRANSPORTE E RISCOS POR VIAS RODOVIÁRIAS}

De acordo com DNIT, os estados com mais relevância para o transporte de cargas perigosa de classificação IMO, são os estados de São Paulo, Minas Gerais, Rio Grande do Sul, Paraná, Rio de Janeiro, Santa Catarina e Espírito Santo e em conformidade ao DNIT, o estado de Minas Gerais possui a maior malha rodoviária do país, cujo total é de $272.062,90 \mathrm{~km}$, e está intrinsicamente ligada as regiões que conectam o porto de Santos a região metropolitana de Campinas, e a chamada Região Metropolitana do Vale do Aço RMVA. Ambas regiões com as suas rodovias são as vias de distribuição da Soda Cáustica para todo o país, porém conforme indica a Confederação Nacional de Transportes - CNT (2019), mais 73,9\% das estradas neste entorno regional, estão com severos danos na pista, que em suma, agravam severamente dos riscos de acidentes. E conforme expõe Silva (2018), em tais atuais condições o ciclo operacional do veículo diminui e com isso ocorre a elevação dos riscos. A região Sudeste apresentou 5.390 acidentes $(32 \%$ do total do país), seguida pela região Sul, o que revela a concentração das ocorrências próximas às zonas de maior atividade e consumidora, em relação a quantidade de vítimas fatais nesses acidentes, a região Sudeste apresentou 559 óbitos (31\% do total), seguida pela região Nordeste, com 519 óbitos (28\% do total). Na tabela 2, a Polícia Rodoviária Federal - PRF fez um balanço para evidenciar o aumento dos casos de acidentes com cargas perigosas na região de Campinas.

Tabela 2 - Acidentes com cargas perigosas na RMC desde 2017

\begin{tabular}{|c|c|c|}
\hline Mês & $\begin{array}{c}\text { Ocorrências em } \\
2019\end{array}$ & $\begin{array}{l}\text { Ocorrências de } 2017 \text { a } \\
2019\end{array}$ \\
\hline Janeiro & 4 & 9 \\
\hline Fevereiro & 1 & 6 \\
\hline Março & 0 & 8 \\
\hline Abril & 4 & 6 \\
\hline Maio & 3 & 3 \\
\hline Junho & 2 & 2 \\
\hline Julho & 4 & 8 \\
\hline Agosto & 2 & 5 \\
\hline Setembro & 1 & 8 \\
\hline Outubro & 2 & 6 \\
\hline Novembro & - & 6 \\
\hline Dezembro & - & 4 \\
\hline Total & 23 & 71 \\
\hline
\end{tabular}

O Sindicato das Empresas de Transportes de Cargas de São Paulo e Região - SETCESP, aponta que há uma exacerbada legislação, mas fiscalização e investimentos que tragam proveitos a este setor não são implementados na mesma medida, tanto pela Agência Nacional do Petróleo, Gás Natural e Biocombustíveis - ANP, quanto pela ANTT. 


\section{RESULTADOS E DISCUSSÃO}

O controle diante a esse segmento onde as ações de cuidado aos acidentes necessitam de informações facilitam a orientação de uma adequação dado a que pesquisas que usam informações com o intuito da coleta, refletem que hoje no Brasil não se permite uma análise profunda das razões causadoras de acidentes. Em média acidentes com corrosivos, como apresenta a característica do hidróxido de sódio, interdita uma rodovia por 4 a 6 horas impossibilitando o fluxo viário. Com o intuito preventivo, a aplicação de treinamentos com agraciamentos de simulados para os transportadores deste tipo de material, é uma moção que porventura caberia como um plano de mitigação de risco, e instituiria o condutor a como se portar em um imprevisto causador de grandes proporções. Precisa que o condutor, além de seguir os parâmetros normativos já devidamente instaurados, é de compêndio clame, que saiba a natureza da carga que transporta, e como é a sua reação diante a outras substâncias danosas ou quando tocada em solo ou rios.

Figura 8 - Plano de mitigação

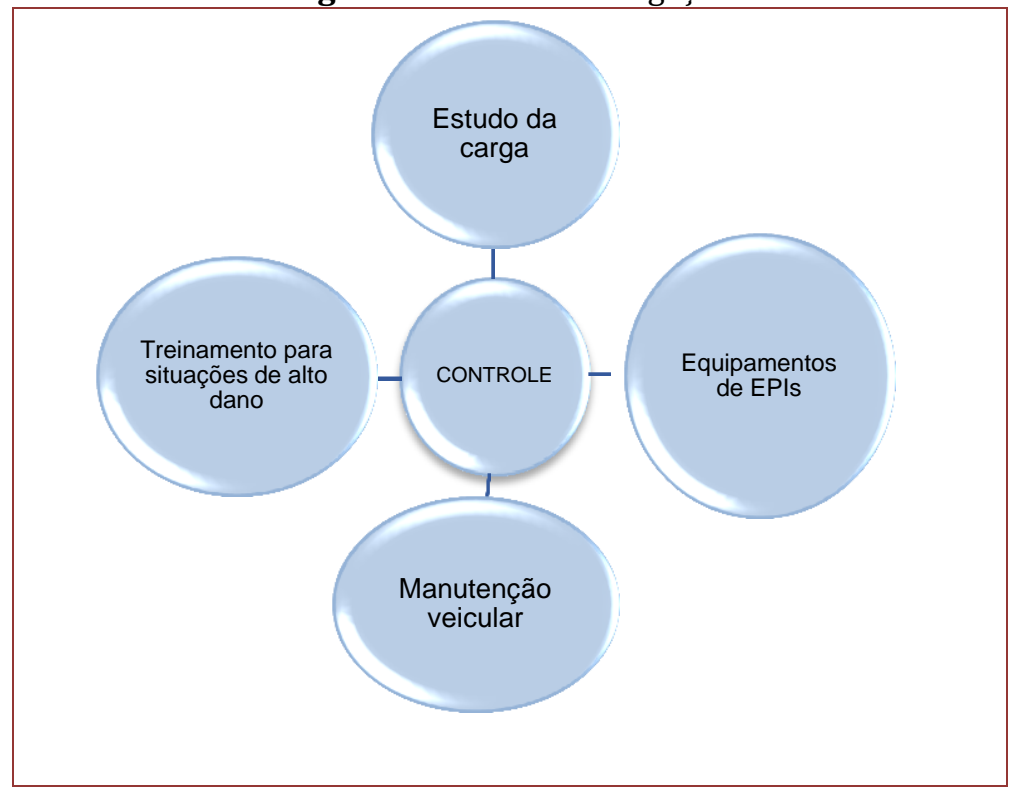

Fonte: CETESB

Dados veiculados pela CETESB, aponta que se o condutor obtiver um amplo conhecimento da carga transportada, e o veículo com condições adequadas as normativas da ANTT, o controle perante acidentes torna-se alto, e o risco de danos agravantes durante o trajeto é amplamente reduzido. Angariando desta forma uma maior qualidade e benefícios ao transporte de cargas perigosas.

\section{CONSIDERAÇÕES FINAIS}

A movimentação do hidróxido de sódio, dentro do cais santista tem um grande apreço devido que a produção interna deste granel, é baixa e não supre a demanda, fazendo com que a importância desta operação do terminal da Dow Química um serviço eficaz que ao longo dos anos obteve uma escala de evolução e trouxe uma maior perspicuidade para o Porto de Santos trazendo tecnologia e inovação a qual facilitou o escoamento e deu a melhora a um todo processo logístico. Mas como todo produto perigoso, as necessidades de fiscalização e segurança é indispensável, coloca-se em pauta uma discussão sobre o 
transporte e de como a melhora poderá ser implementada, onde que as exigências aplicáveis perante a atividade de transporte de produtos perigosos propiciarão acrescentar o máximo nível de segurança cabível tanto para a população como para o meio ambiente. Sendo assim, é manifestando uma indigência que os enredados neste setor adquiram a consciência do âmbito de cumprimento da legislação para mitigar ao máximo os percalços que envolvem esse tipo de transporte.

\section{REFERÊNCIAS}

[1]. AGÊNCIA NACIONAL DE TRANSPORTE AQUAVIARIO. Anuário. Disponível em. http://web.antaq.gov.br/portalv3/Anuarios/Portuario2009/termos.htm. Acesso em. 28 de Ago de 2020

[2]. AGÊNCIA NACIONAL DE TRANSPORTE AQUAVIARIO. Cargas perigosas. Disponível em. http://portal.antaq.gov.br/index.php/meio-ambiente/cargas-perigosas/. Acesso em. $20 \mathrm{de}$ Set de 2020

[3]. ANTT. Cargas perigosas. Disponível em.

https://www.antt.gov.br/cargas/Produtos_Perigosos.html. Acesso. 23 de Ago de 2020

[4]. ASSOCIAÇÃO BRASILEIRA DA INDUSTRIA DE CLORO ÁLCALIS E DERIVADOS. Soda Cáustica. Disponível em http://www.abiclor.com.br/soda-caustica/. Acesso em 23 de Set de 2020

[5]. Balou, Ronald H. Gerenciamento da cadeia de suprimentos/logística empresarial / Ronald H. Bailou ; tradução Raul Rubenich. - 5. ed. - Porto Alegre : Bookman,2006. 616 p .; 28 cm.

[6]. BRAGA, JOSÉ MAURO FERNANDES. ANÁLISE DA VIABILIDADE ECONÔMICA DA INTEGRAÇÃO DE SISTEMAS DE CÉLULA A COMBUSTÍVEL, NAS PLANTAS DE CLORO-SODA, PARA UTILIZAÇÃO DO HIDROGÊNIO GERADO NO PROCESSO. Rio de Janeiro, 2009. Disponível em: http://www.eq.ufrj.br/sipeq/download/integracao-de-sistemas-de-celula-acombustivel.pdf. Acesso em: 18/09/2020.

[7]. BRASKEM. Ficha de Informações de Segurança de Produtos. Disponível em: http://www.braskem.com.br/cms/Principal/produto/download?id=97Epgrm/Tu4=\&produto= true. Acesso 23 de Out 2020

[8]. CARPOLOG. Cargas perigosas IMO principais aspectos e exigências. Disponível em. http://www.carpolog.com.br/blog/cargas-perigosas-imo-principais-aspectos-e-exigencias/. Acesso em. 20 de Set de 2020

[9]. CETESB. Hidróxido de Sódio. Disponível em. https://sistemasinter.cetesb.sp.gov.br/produtos/ficha_completa1.asp?consulta=HIDR\%C3\%93X IDO\%20DE\%20S\%C3\%93DIO,\%20SOLU\%C3\%87\%C3\%830. Acesso em 28 de Ago de 2020

[10]. CNT. Confederação Nacional de Transporte. Disponível em.

https://pesquisarodovias.cnt.org.br/Paginas/relatorio-gerencial. Acesso em 28 de Ago 2020

[11]. CNT. Confederação nacional de transporte. Disponível em:

https://www.cnt.org.br/agenciacnt/somente-12-da-malha-rodoviaria-brasileira-pavimentada. Acesso 28 de Ago 2020

[12]. DEPARTAMENTO NACIONAL DE TRÂNSITO. Cargas Perigosas. Disponível em. http://sistemas.dnit.gov.br/cargasperigosas/paginas. Acesso em. 28 de Ago de 2020

[13]. FERNANDES et All. O SETOR DE SODA-CLORO NO BRASIL E NO MUNDO. BNDES Setorial, Rio de Janeiro, n. 29, p. 279-320, mar. 2009. Disponível em: http://www.bndes.gov.br/SiteBNDES/export/sites/default/bndes_pt/Galerias/Arquivos/conhe cimento/bnset/Set2908.pdf. Acesso em 03/09/2020. 
[14]. GIL, A. C. Métodos e técnicas de pesquisa social. 6. ed. São Paulo: Atlas, 2008.

[15]. G1. Região de Campinas tem alta em acidentes com cargas perigosas e registra 71 casos desde 2017. Disponível em. https://g1.globo.com/sp/campinas-

regiao/noticia/2019/11/12/regiao-de-campinas-tem-alta-em-acidentes-com-cargas-perigosase-registra-71-casos-desde-2017.ghtml. Acesso. 25 de Ago de 2020

[16]. IMO. Insurance Maritime Organization. Disponível em.

http://www.imo.org/en/About/Pages/Default.aspx. Acesso em. 01 de Out de 2020

[17]. LEWA. Aplicações da Soda caustica. Disponível em:

https://www.lewa.com.br/pt/aplicacoes/producao-de-soda-caustica/. Acesso 23 de Out de 2020

[18]. MAPA. MINISTÉRIO DA AGRICULTURA PECUARIA E ABASTECIMENTO. Disponível em: http://sistemasweb.agricultura.gov.br/sislegis/action/detalhaAto.do?method=visualizarAtoPor talMapa\&chave $=1684581244$. Acesso 23 de Out de 2020

[19]. MASSOLI, M.P. XI JORNADA BRASILEIRA DE QUEIMADURAS. 2019. (Congresso).

[20]. MDIC - Estatísticas de Comércio Exterior - Comex Stat. Disponível em. http://comexstat.mdic.gov.br/pt/geral/18257. Acesso. 23 de Ago de 2020

[21]. PORTAL DA QUIMICA. Eletrolise. Disponível em. https://www.soq.com.br/conteudos/em/eletroquimica/p4.php. Acesso em. 28 de Ago de 2020

[22]. PRODANOV, Cleber Cristiano. Metodologia do trabalho científico: métodos e técnicas da pesquisa e do trabalho acadêmico / Cleber Cristiano Prodanov, Ernani Cesar de Freitas. - 2. ed. Novo Hamburgo: Feevale, 2013

[23]. SANTOS PORT AUTHORITY. Relatório estatístico. Disponível em.http://intranet.portodesantos.com.br/docs_codesp/doc_codesp_pdf_site.asp?id=128686 Acesso. 23 de Ago de 2020

[24]. SETCESP. 21 Caminhões com carga perigosa são multados em operação no anel rodoviário. Disponível em: https://setcesp.org.br/noticias/21-caminhoes-com-carga-perigosasao-multados-em-operacao-no-anel-rodoviario/. Acesso 23 de Set de 2020

[25]. SILVA, PAULO SÉRGIO RIBEIRO DA (2018) Recuperação da Fernão Dias é fundamental para Minas Gerais, Associação Brasileira de Concessionárias de Rodovias (ABCR). Disponível em: http://www.abcr.org.br/. Acesso em janeiro/2018.

[26]. TECNOTRI. Armazenamento seguro na indústria de transformação. Disponível em: https://www.tecnotri.com.br/armazenamento-seguro-na-industria-de-transformacao/. Acesso 25 de Out de 2020

[27]. TRADE MAP. Disponível em:

https://www.trademap.org/Country_SelProductCountry.aspx?nvpm=1\%7c076\%7c\%7c\%7c\%7 c281512\%7c\%7c\%7c6\%7c1\%7c1\%7c1\%7c1\%7c1\%7c2\%7c1\%7c1\%7c1. Acesso em 16 de Set de 2020

[28]. UFV. Armazenamento de Produtos químicos . Disponível em: https://www.segurancadotrabalho.ufv.br/armazenamento-de-produtos-quimicos/ Acesso 22 de Out de 2020

[29]. WEB PORTOS. Terminal Marítimo Dow. Disponível em: https://webportos.labtrans.ufsc.br/Tup/Index/99. Acesso em. 28 de Ago de 2020 


\section{Capítulo 15}

\section{Panorama temporal da exportação brasileira de sucata metálica ferrosa}

\section{Rafael Chaves Osidacz}

\section{Danilo Soares Leitão}

Rafael de Sousa Oliveira

Resumo: 0 setor de sucata metálica ferrosa representa uma oportunidade promissora de exportação de comodities de baixo valor agregado. 0 Brasil explora muito pouco os benefícios econômicos, ambientais e sociais incluídos na comercialização deste insumo, visto que este segmento representa um meio de desenvolvimento econômico e social para o país por ser um produto com alto potencial de reciclagem. A finalidade desta pesquisa foi demonstrar graficamente os baixos índices da participação brasileira em comparação aos principais exportadores mundiais e os gargalos que surgem quando são analisados os principais importadores do planeta. As análises foram realizadas através de dados quantitativos, econômicos e temporais. Conclui-se que para melhorar a logística do setor é necessário modernização de equipamentos e portos, como também maiores incentivos fiscais e tributários para fortalecimento do segmento sucateiro metálico ferroso.

Palavras-chave: Sucata metálica ferrosa. Panorama. Exportação. Brasil. 


\section{INTRODUÇÃO}

A sucata ferrosa é um importante insumo para a indústria siderúrgica, como também representa um meio de desenvolvimento econômico e social para o país por se tratar de um produto com alto grau de reciclabilidade. 0 baixo market share brasileiro em relação aos principais exportadores de sucata ferrosa no mundo chama atenção para a necessidade de incrementação do setor.

De acordo com o Instituto Nacional das Empresas de Sucata de Ferro (INESFA, 1975), o aço quando produzido integralmente por meio de sucata metálica ferrosa, proporciona redução de $85 \%$ de poluição do ar e $76 \%$ menos consumo de água quando comparado aos meios tradicionais de obtenção do material. Além disso, favorece a conservação do meio ambiente através da eliminação de todos os impactos acarretados pela atividade mineradora.

O objetivo desta pesquisa foi identificar as variações positivas e negativas no setor de sucata metálica ferrosa, principalmente relacionadas as exportações desta commodity, juntamente demonstrar possíveis gargalos logísticos e econômicos existentes na comercialização deste insumo com os principais países importadores.

A análise deste estudo foi realizada abrangendo aspectos temporais, quantitativos e financeiros pertinentes ao setor de sucata metálica ferrosa em âmbito nacional e internacional.

\section{EMBASAMENTO TEÓRICO}

A sucata metálica ferrosa pode ser originada de quatro maneiras, em concordância com Andrade et al, 2000. Quando o aço se torna sucata formada na própria usina é classificada como sucata de geração interna e geralmente retorna ao forno. Existe também uma sucata de alta qualidade por ter baixa contaminação em sua composição química, a qual é originada pela geração industrial de metalúrgicas e plantas industriais. Não obstante, bens de consumo de aço ou ferro quando já considerados obsoletos para utilização, convertem-se em sucata de obsolescência. Finalmente, a partir do momento em que unidades industriais são demolidas ou máquinas e equipamentos tornam-se obsoletos, geram bens de capital sucateados.

Para ser adquirida no mercado e reaproveitada nas indústrias siderúrgicas, a sucata precisa ser coletada e beneficiada através de instrumentos como prensas, tesouras e shredders. Na maioria das vezes, agentes, distribuidores e processadores pertencentes as indústrias sucateiras realizam estas atividades. No entanto, a depender das condições de cada mercado, podem ficar a cargo das próprias siderúrgicas (ANDRADE et al, 2000).

\section{RESULTADOS E DISCUSSÕES}

\subsection{EXPORTAÇÃO EM VOLUMES MOVIMENTADOS}

Conforme mostrado no Gráfico 1, os principais países exportadores em quantidade de sucata ferrosa no ano de 2019 foram Estados Unidos (16,8\%), Alemanha (8,6\%), Reino Unido (8,2\%), Japão (7,8\%), França $(6,7 \%)$ e Holanda $(6,4 \%)$. Juntos, os seis países apontaram por $54,5 \%$ das exportações mundiais do insumo em 2019. 0 Brasil participou apenas com $0,71 \%$ do total no mesmo período, correspondente a 710 mil toneladas, aparecendo na $25^{\text {a }}$ colocação mundial. Entretanto, houve significativo acréscimo de 99,4\% nas exportações comparado ao ano anterior, no qual o Brasil apresentou-se na 
47ํㅜ colocação mundial, com participação de somente $0,34 \%$, tendo 356 mil toneladas exportadas.

Gráfico 1 - Volume exportado pelo Brasil e principais países exportadores de sucata ferrosa em 2019

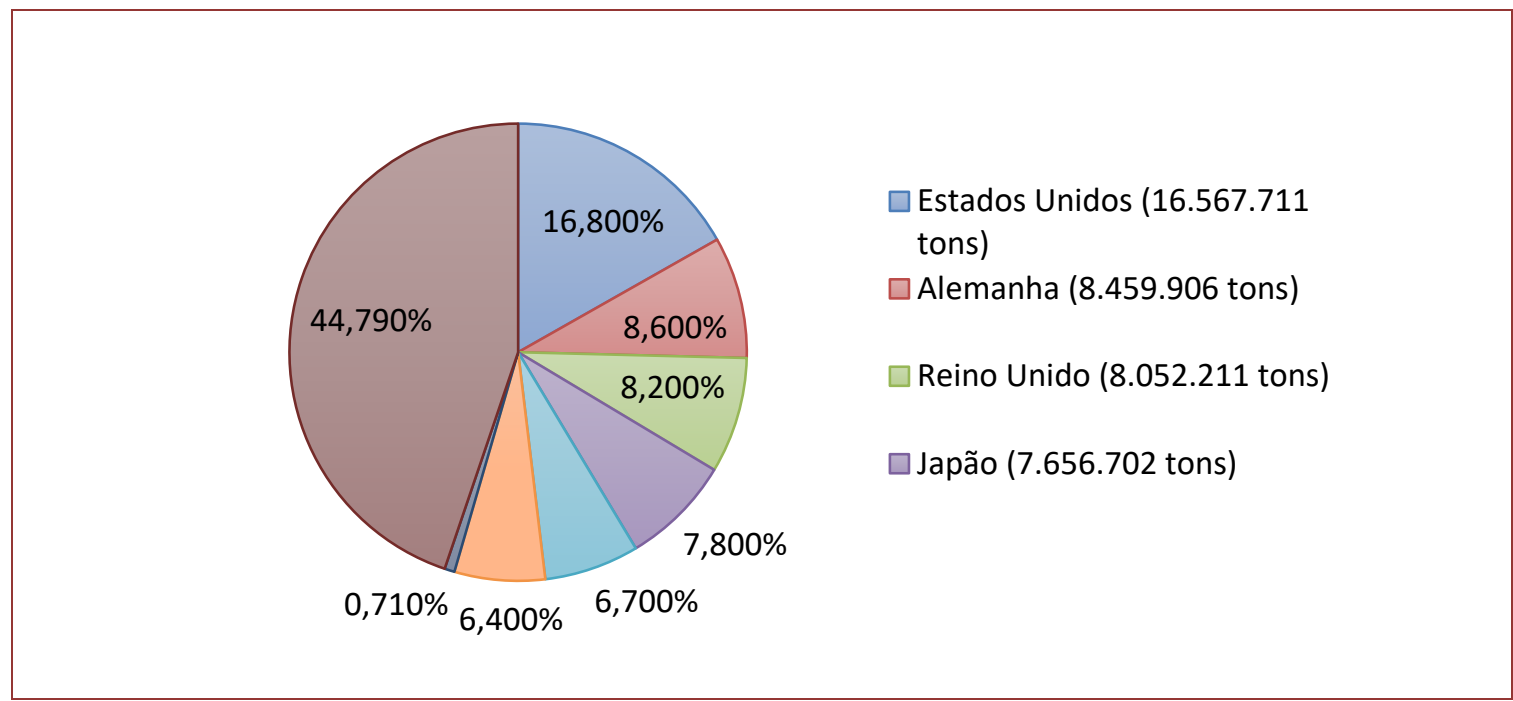

Fontes: Trade Map (ITC) e Comexstat (MDIC). Adaptado pelo autor.

Com o objetivo de ter uma visão macro sobre a série histórica relacionada aos dados referentes a quantidade exportada de sucata ferrosa pelo mercado brasileiro anualmente, o Gráfico 2 torna esta perspectiva extremamente viável. Por ele, é possível notar que a partir de 2010 houve substancial acréscimo no peso exportado até 2015, saltando de 80 mil para 679 mil toneladas. A partir desde ano, a tendência foi decréscimo permanente até 2018, quando fechou o ano com 356 mil toneladas exportadas. No entanto, as exportações foram desfrutadas em larga escala a partir do início de 2019, praticamente duplicando o volume exportado. Esta melhora nos números referentes a exportação do insumo ainda é aparente em tempos atuais, porém com alguma oscilação entre setembro de 2019 a maio de 2020, como mostrado no Gráfico 3.

Gráfico 2 - Série histórica anual - peso exportado pelo Brasil (2010 a 2019)

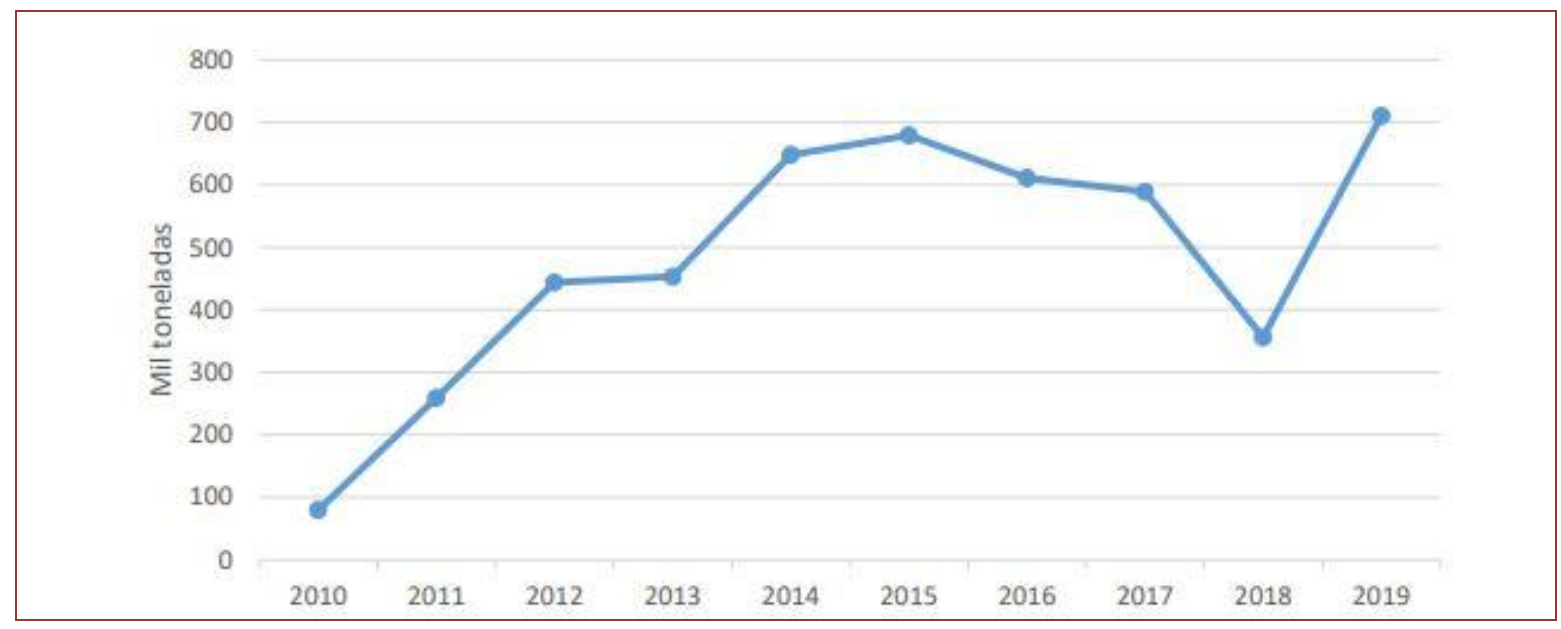

Fonte: Comexstat (MDIC). Adaptado pelo autor. 
Gráfico 3 - Oscilações nos volumes exportados pelo Brasil (set. 2019 a mai. 2020)

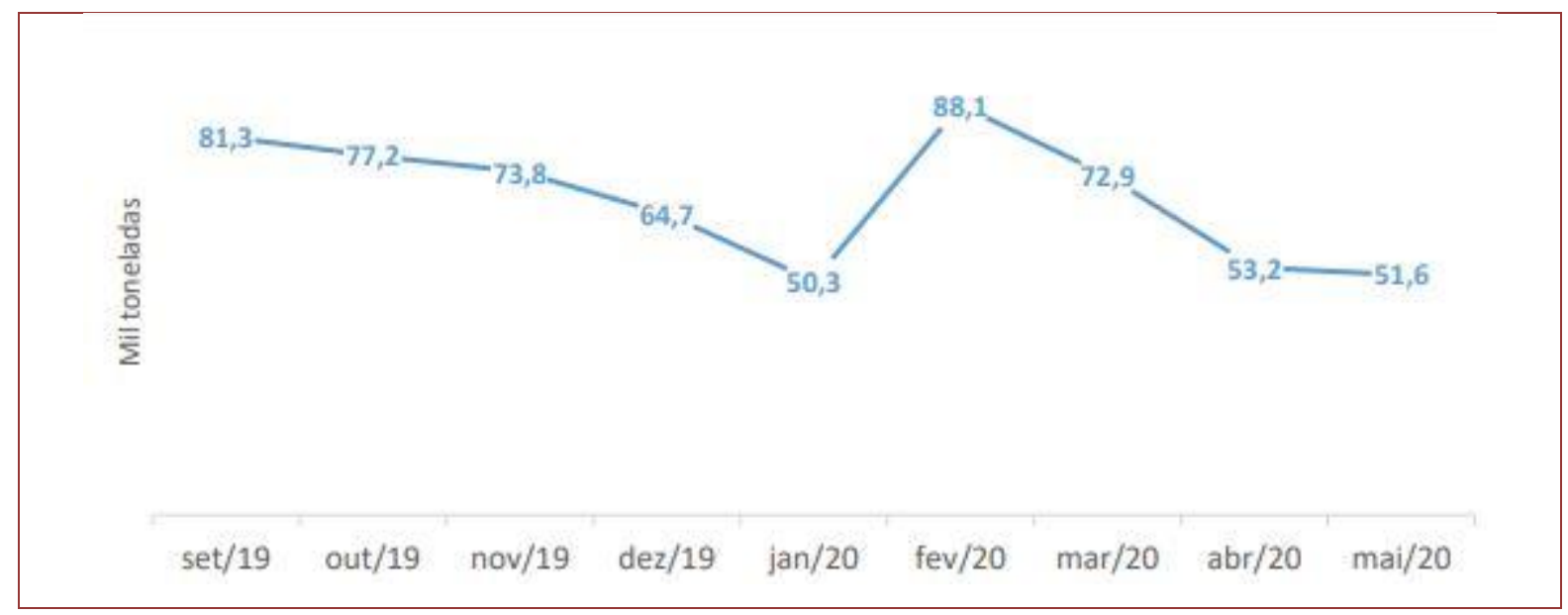

Fonte: Comexstat (MDIC). Adaptado pelo autor.

Ainda que tenha existido declínio de toneladas exportadas de sucata ferrosa no período entre fevereiro a maio de 2020, quando é feita comparação em relação aos acumulados nos intervalos de janeiro a maio de 2019 e 2020, nota-se que ocorreu elevação de 63,3\% em massa exportada, de 194 mil toneladas para 316 mil. Fato este não refletido na mesma proporção sobre o faturamento, já que financeiramente houve aumento de apenas 8,6\%. Esta não conformidade foi reflexo da baixa do preço acumulado entre os períodos, indo de 0,34 para 0,23 dólares por quilograma (US\$/Kg), representando diminuição de 33,5\% neste intervalo de tempo, de acordo com dados disponibilizados pelo Ministério do Desenvolvimento, Indústria e Comércio Exterior (MDIC).

\subsection{EXPORTAÇÃO EM CAPITAL MOVIMENTADO}

Uma série de fatores definem o preço da sucata ferrosa. Por ser um mercado de livre concorrência, aspectos regionais de oferta e demanda são consideráveis causas que influenciam o valor do material. Outra circunstância influenciadora que afeta fortemente o preço é a produção de aço mundial.

O Gráfico 4 ilustra os valores financeiros em dólares estadunidenses (US\$) no ano de 2019 correspondentes as exportações de sucata ferrosa brasileira e dos principais países exportadores. 0 Brasil ocupou a 30ª posição, tendo exportado aproximadamente 208 milhões, o que representou apenas 0,61\% do total mundial. No intuito de comparação, os Estados Unidos, cujo país tenha exportado para 80 países no mesmo ano, contra 36 países importadores do Brasil, declarou ter vendido aproximadamente 5 bilhões e 340 milhões de dólares para o exterior, representando 15,8\% do total exportado pelo mundo. Já a soma do capital exportado pelos seis principais países referências em sucata ferrosa correspondeu a 54,9\% do total. 
Gráfico 4 - Valores exportados (US\$) pelo Brasil e principais países exportadores de sucata ferrosa em 2019

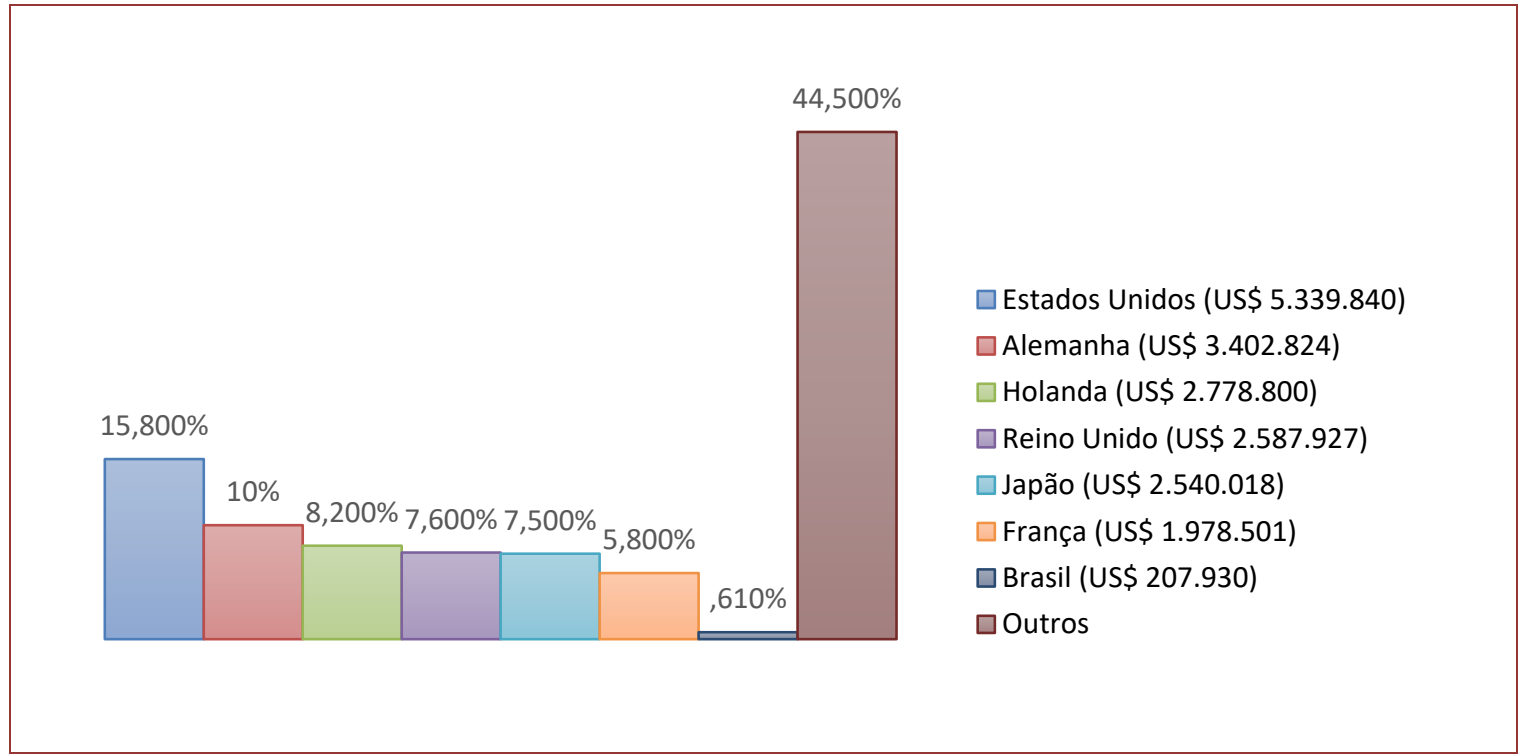

Fontes: Trade Map (ITC) e Comexstat (MDIC). Adaptado pelo autor.

São expostos valores referentes aos preços médios das exportações brasileiras no Gráfico 5, é notável que os montantes a partir do ano 2010 até 2016 permaneceram em constante queda, iniciado em 0,84 e finalizado em 0,24 dólares por quilograma, excluindo apenas o período entre 2013 e 2014 em quem o preço médio se manteve constante em 0,39 US\$/Kg. No entanto, de 2016 a 2018 houve constante aumento do preço médio, chegando ao patamar de 0,45 US\$/Kg. Neste momento, outra oscilação é observada com decréscimo até 0,29 dólares por quilo na média em 2019.

Gráfico 5 - Preço médio (US\$/Kg) das exportações brasileiras de sucata ferrosa (2010 a 2019)

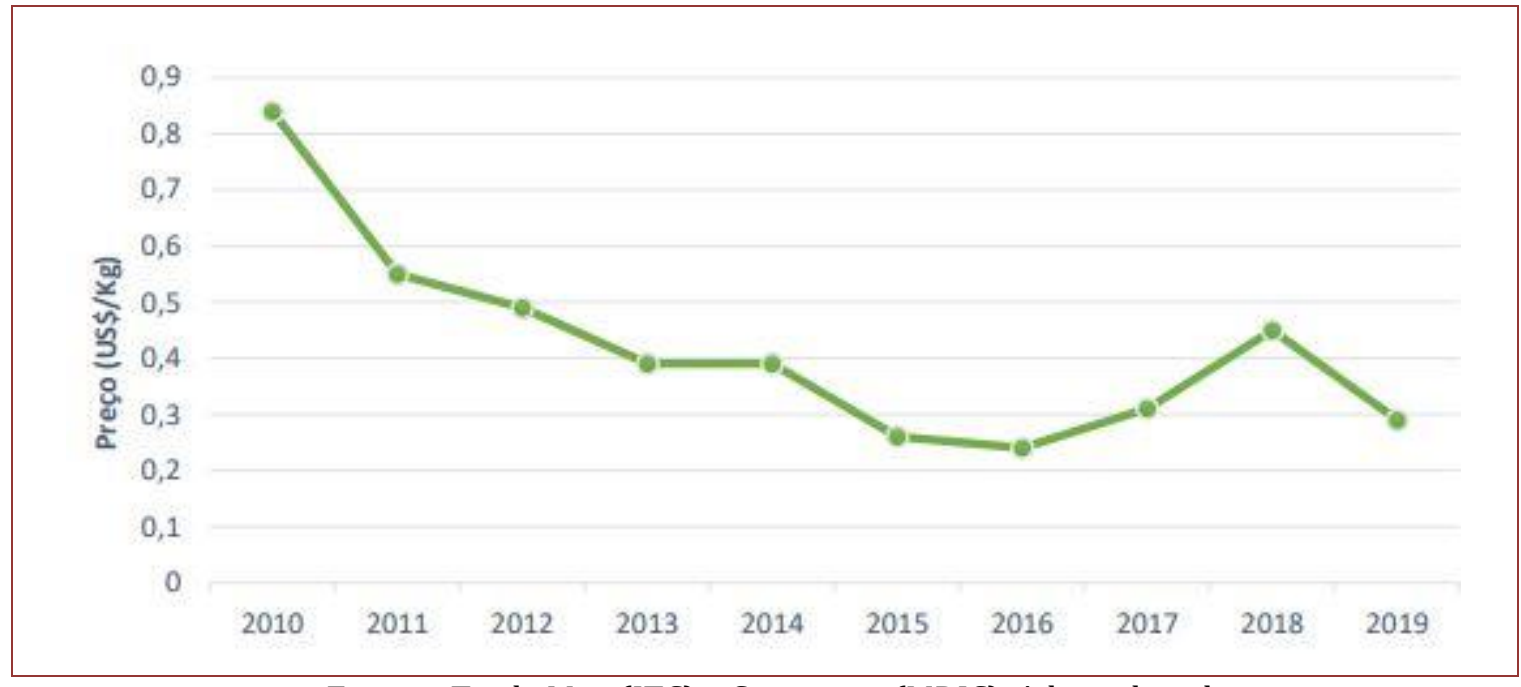

Fontes: Trade Map (ITC) e Comexstat (MDIC). Adaptado pelo autor.

Ao observar a série temporal no Gráfico 6 sobre o capital exportado pelo Brasil no período entre os anos 2010 e 2019, repara-se que até 2012 existiu elevação de 226\%, 
indo de 67,1 para 219 milhões de dólares. A partir de então, é observado permanente oscilação nos valores exportados ano após ano. Entre 2012 e 2019, a média de sucata ferrosa exportada em capital foi de 190,5 milhões US\$.

Gráfico 6 - Série histórica anual - valor US\$ exportado pelo Brasil

(2010 a 2019)

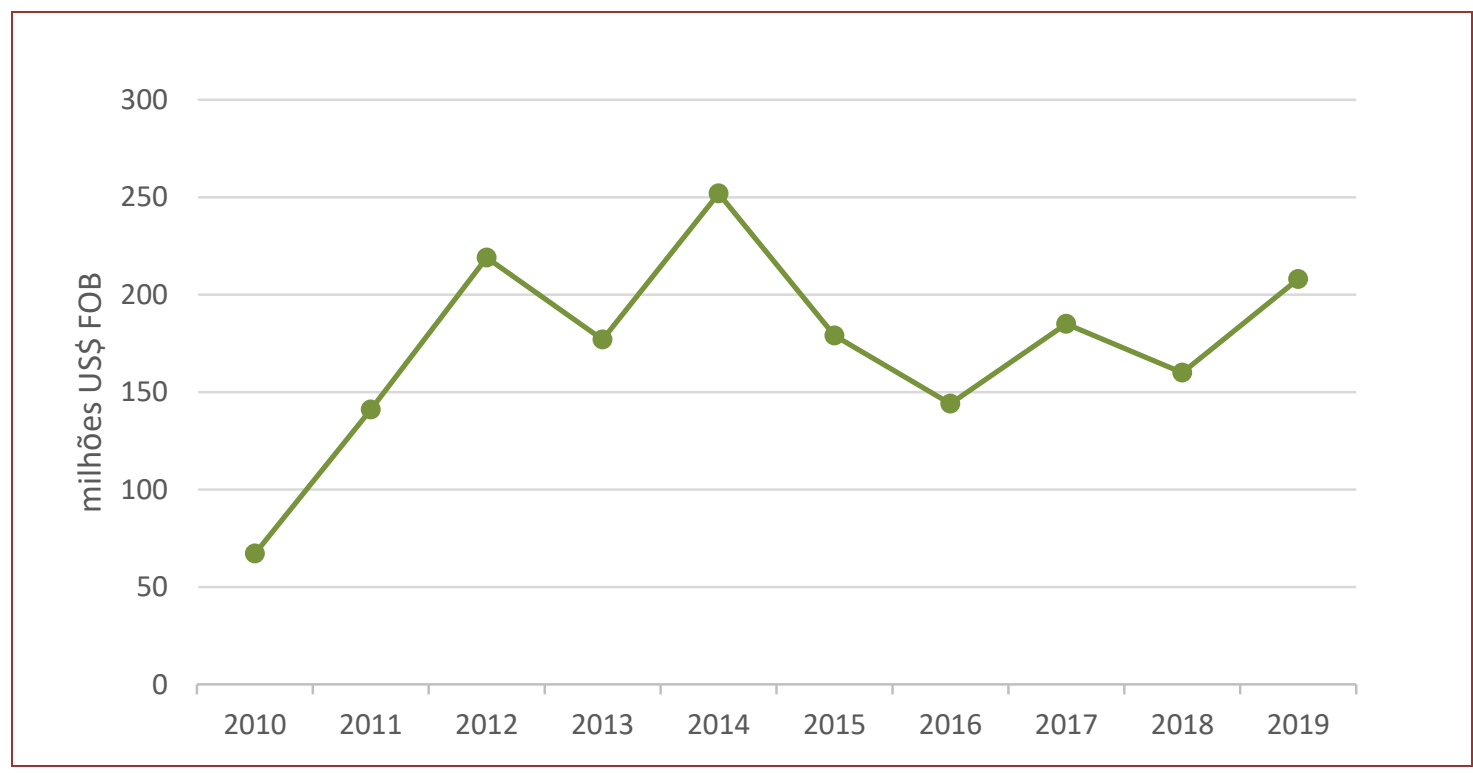

Fonte: Comexstat (MDIC). Adaptado pelo autor.

Oscilações nos valores de capital exportado continuaram ocorrendo no período de setembro de 2019 a maio de 2020, como observado no Gráfico 7. Contudo, ao traçar uma linha de tendência linear para o período, enxerga-se que a propensão futura próxima é de decréscimo nos valores financeiros exportados.

Gráfico 7 - Oscilações nos valores US\$ exportados pelo Brasil (set. 2019 a mai. 2020)

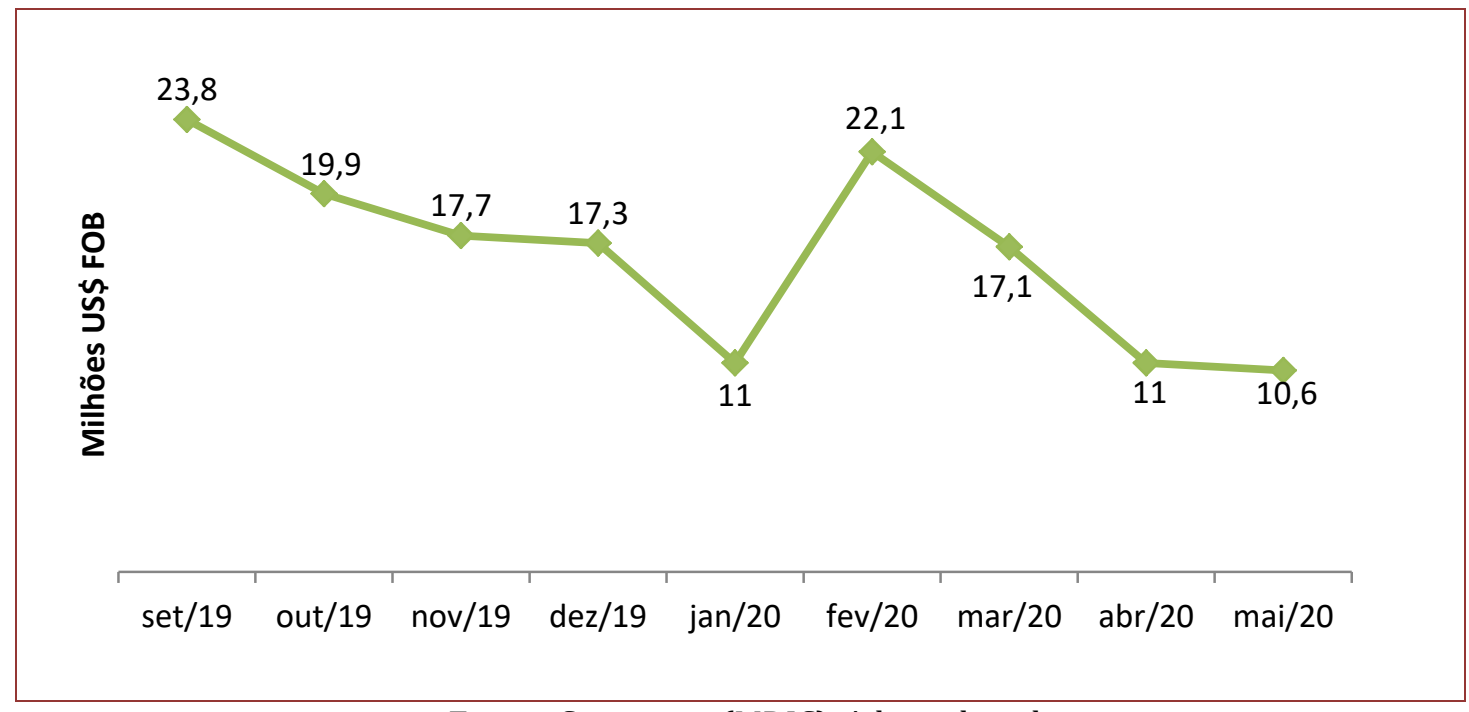

Fonte: Comexstat (MDIC). Adaptado pelo autor. 


\subsection{PRINCIPAIS PAÍSES IMPORTADORES}

O Brasil exportou sucata metálica ferrosa para 36 países em 2019, sendo que os cinco principais importadores foram Bangladesh, Índia, Indonésia, Paquistão e Emirados Árabes Unidos. Respectivamente, os valores em mil toneladas foram aproximadamente 251, 149, 139, 72 e 28, como informado no Gráfico 8. Estes cinco países receberam $91,5 \%$ do total exportado pelo Brasil no referido ano. É possível também observar a evolução oscilante das quantidades importadas pelos países mencionados no período de 2015 a 2019.

Gráfico 8 - Principais países importadores de Sucata Ferrosa brasileira (2015 a 2019)

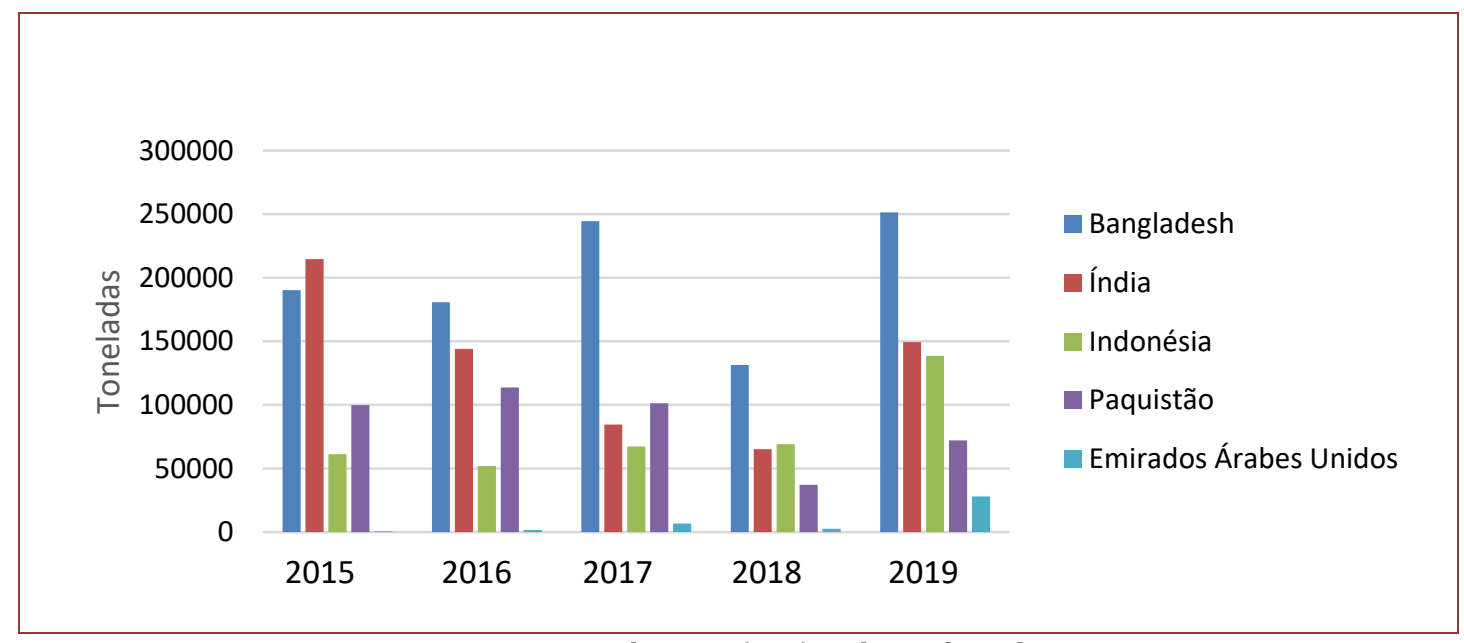

Fonte: Trade Map (ITC). Adaptado pelo autor.

Dentre os 153 países importadores de sucata metálica em 2019, de acordo com dados disponíveis no Trade Map-ITC, a Turquia consagra-se a maior importadora do insumo no planeta, como exposto no Gráfico 9, sobretudo por quase toda a produção de aço ser feita através de forno elétrico e arco, mais conhecido como FEA, conforme Trindade Jr, 2013. Neste sentido, a demanda turca pela sucata ferrosa acaba baseando os preços mundiais por representar alto valor do market share global. Índia, Coréia do Sul, Itália e Vietnã surgem na sequência como principais importadores em 2019. Juntos, os cinco principais importadores respondem por $42,6 \%$ do total. Além disso, no Gráfico 9 também pode-se visualizar a variação temporal dos cinco principais importadores entre 2015 e 2019 e mostrar visualmente a supremacia turca nas importações mundiais.

A Turquia apenas recebe sucata a granel, o que torna este fato um dos principais empecilhos para que a sucata brasileira seja definitivamente vendida para o país líder em importações mundial. Todavia, o Brasil não possui portos adaptados para este tipo de embarque, os quais exigem equipamentos especiais como eletroímãs e garras para embarques rápidos, além de necessitarem áreas de estocagem adaptadas (VERÍSSIMO, 2017). 
Gráfico 9 - Principais países importadores de Sucata Ferrosa mundial (2015 a 2019)

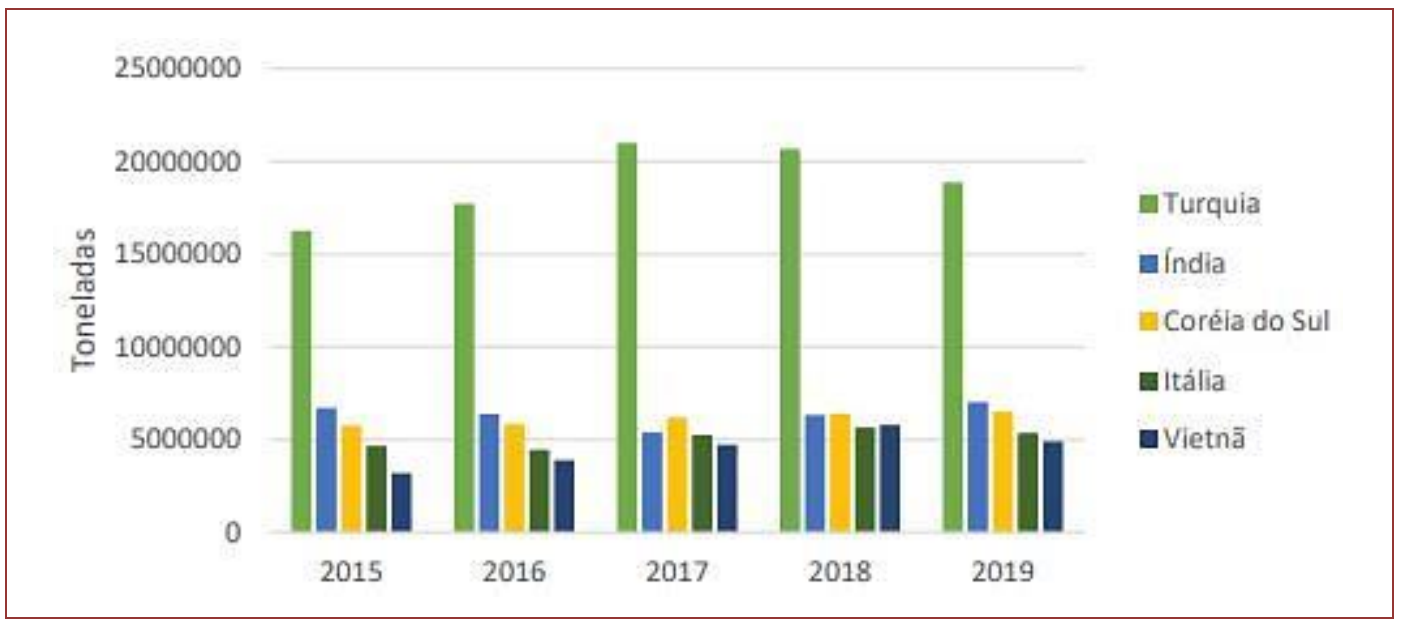

Fonte: Trade Map (ITC). Adaptado pelo autor.

\section{CONSIDERAÇÕES FINAIS}

O Brasil, uma nação com economia em desenvolvimento, apresenta oportunidades para aprimoramento e melhor aproveitamento do setor de sucata ferrosa, tendo em vista a extremamente baixa participação no comércio exterior. Em virtude da parcela tão pequena de atuação internacional no setor, a demanda e oferta nacional não são capazes de influenciar o preço internacional da commodity.

A diminuição de atividades produtivas nacionais em setores como civil e automobilístico refletiu em redução da procura por esta commodity no mercado interno brasileiro, proporcionando tendências de mercado em direção a mais toneladas de sucata ferrosa exportadas com propósito compensatório sobre a baixa demanda nacional, como observado na variação positiva de exportações entre 2018 e 2019.

Com o objetivo de melhor explorar o mercado de sucata metálica ferrosa e o potencial brasileiro para exportação, é aconselhável que exista aquisição e modernização de equipamentos e portos, no intuito de expandir a logística do setor. Outros fatores determinantes para evolução do segmento estão relacionados ao surgimento de novos incentivos fiscais e melhores tarifas portuárias para estimular negociações de commodities com baixo valor agregado, como o caso da sucata metálica ferrosa.

\section{REFERÊNCIAS}

[1]. ANDRADE, Maria Lúcia Amarante de et al. Mercado Mundial de Sucata. Novembro. 2000. Disponível em: <http://www.bndes.gov.br/SiteBNDES/export/ sites/default/bndes_pt/Galerias/Arquivos/conhecimento/relato/sucata.pdf>. Acesso em: 20 mai. 2020.

[2]. GOVERNO FEDERAL. MDIC. Resíduos e sucata de metais ferrosos. 2020. Disponível em: <http://comexstat.mdic.gov.br/pt/comex-vis>. Acesso em: 10 jun. 2020.

[3]. INESFA. Instituto Nacional das Empresas de Sucata de Ferro e Aço. 1975. Disponível em: <http://www.inesfa.org.br/reciclagem.php>. Acesso em: 18 maio 2020.

[4]. TRADE MAP. ITC. Trade statistics for international business development. Disponível em: <https://www.trademap.org>. Acesso em: 10 jun. 2020. 
[5]. TRINDADE JR, José Carlos Nogueira. Obtenção, mercado e reciclagem de sucatas ferrosas na indústria siderúrgica brasileira. Projeto de Graduação. Universidade Federal do Rio de Janeiro. Rio de Janeiro, RJ, 2013.

[6]. VERÍSSIMO, Cabral. Sucateiros Do Brasil: Clube de Autores, 2017. 32 p. 


\section{Capítulo 16}

Logística 4.0 e sustentabilidade: Um novo conceito entre o meio ambiente e a tecnologia no porto

\section{Elyza Gomes Rebolo}

Josué Elias de Souza Junior

Resumo: 0 Porto é a principal porta de entrada e saída não apenas de mercadorias conteinerizadas ou brutas, mas da conexão global; intermediando produtos, culturas, comunicação e valores. A indústria portuária tende a obter mais avanços com o passar dos anos, mas ainda se utilizam combustíveis fósseis para a funcionalidade dos guindastes e das embarcações, o que contrasta no quesito da poluição, ainda que conquistem recordes de movimentação, já que polui de igual modo. 0 presente artigo objetivou a construção de um estudo baseado na utilização da Tecnologia Sustentável no setor Portuário. Visto que ambos os fatores em sinergia contribuem para um melhor desempenho de recursos e operações, podemos dizer que, sem dúvidas, o meio ambiente e a tecnologia são os novos pilares do futuro.

Para a realização deste tema, foi utilizada a pesquisa bibliográfica como base da metodologia, a partir das informações coletadas e de acordo com as demais publicações, podendo-se acentuar e contestar esta abordagem de maneira mais assertiva.

Palavras-chave: Porto, Sustentabilidade, Tecnologia, Informação. 


\section{INTRODUÇÃO}

Os Portos do Brasil e do mundo tiveram e estão em gigantesco crescimento operacional na gestão de cadeia logística e em sua infraestrutura. Outro fator que tende a ser abordado com mais frequência é a autonomia nos terminais, que utiliza a Indústria 4.0, que é o termo referente a atual era tecnológica aplicada à logística, tendo grande potencial para alavancar todo o setor logístico e portuário no presente e no futuro próximo. Há ainda a conversação acerca da próxima revolução, onde se encaixa a inteligência artificial, a Internet 5G e automação nos Portos.

Desta forma, o trabalho visa demonstrar não somente a evolução econômica, como também o ideal do desenvolvimento de forma sustentável, utilizando e implementando a tecnologia, que é de grande importância para preservar nossos recursos e evitar custos e perdas maiores, assim como possíveis desastres ambientais, alguns podendo ser irreparáveis. Com isto, podemos dizer que a tecnologia e o meio ambiente podem ter sinergia, rendendo maiores benefícios para o Ambiente Marítimo, Portuário e as cidades que o cercam.

\subsection{DESENVOLVIMENTO}

Com base na temática descrita e acerca da implementação de novas ferramentas em prol de soluções inovadoras, tanto no ramo tecnológico quanto ambiental, é salientado que a correlação e a relação da Logística com a sustentabilidade pode desencadear uma gama de pontos a serem explorados, visando contribuir com práticas que utilizem menos recursos naturais e energias não renováveis para as futuras operações automatizadas dos portos brasileiros. (VDI Brasil, 2020).

Sendo assim, são apresentadas novas linguagens e conceitos através da "Internet das Coisas, dos Dados e dos Serviços". Com isto, a interação entre o real e o virtual traz uma nova perspectiva para os processos atuais. Além disso, conforme relatado pela Portogente (2017), a forma revolucionária traz um novo paradigma ao descentralizar a produção, com avanços tecnológicos que trouxeram uma lógica reversa ao sistema convencional. 0 desenvolvimento dos sistemas ciber-físicos traz vantagens competitivas maiores, comparado ao sistema tradicional, assim possibilitando produtos com mais qualidade com custos menores e tempo reduzido. Em outras palavras, isso permite um serviço mais sustentável, flexível e auto adaptável.

\section{INDÚSTRIA 4.0}

Para Hermann (2015), a indústria 4.0 também conhecida como a Quarta Revolução Industrial é um termo que objetiva a utilização de um coletivo de tecnologias e fábricas inteligentes diante ao monitoramento de processos de produção. Visando implementar a automação industrial utilizando um conjunto de tecnologias com o objetivo de melhorar a produção, implementando a utilização da inteligência artificial, computação em nuvem e internet das coisas, permitindo que o maquinário além de processar os produtos, se mantenham conectadas transmitindo informações em um sistema ciber físico. Com isto, trazendo para a indústria mais informações sobre a produção, como por exemplo: maior qualidade, flexibilização na produção, redução de custos, redução de acidentes de trabalho e melhor produtividade na Indústria.

Com isto em mente notamos que a Automação de trabalho, acrescentando maior flexibilização e melhorias na própria indústria, com a redução de custos podemos alocar 
parte dos gastos no desenvolvimento de novas tecnologias voltadas para a produção da empresa, assim também como novas especialidades implementadas no mercado de trabalho, gerando também novos empregos.

\subsection{LOGÍSTICA}

Entende-se por logística, um conjunto de métodos e meios destinados a fazer o que for preciso para entregar os produtos certos, no local adequado, no tempo combinado. A origem desta palavra vem do grego logistiké (logistikos), e significa habilidades de cálculo e tudo que se refere ao raciocínio lógico (MAIS POLÍMEROS, 2019). Dentro desta, existem outras vertentes, tornando o termo e seus processos operacionais mais flexíveis, sinérgicos e direcionados para outros setores, por exemplo, a logística empresarial, integrada e reversa.

A Logística Integrada representa a união de todo o processo, desde a origem dos produtos até chegar ao consumidor final. 0 fluxo logístico é coordenado de maneira otimizada através de sistemas inteligentes, oferecendo o melhor para o cliente no momento da compra. Estes processos são integrados em sistemas que aumentam a eficiência das ações corporativas, gerenciando as informações ao longo da cadeia de suprimentos, assim tornando seus resultados mais satisfatórios.

Para Mazzeo (2001), a logística é responsável por minimizar e eliminar custos, buscando um sucesso efetivo da empresa que a incorpora. Com esta prática otimizando atividades e aprimorando a cadeia de produção com maior eficiência e menor custo.

Tendo isto em vista, a logística 4.0 consiste em utilizar processos inteligentes como a automação e a conexão com a internet em toda empresa, objetivando a automatização da organização e auxiliando no aumento da produtividade. Dentro deste parâmetro, passam a ser aplicadas ferramentas como a Internet das Coisas, o Blockchain, Inteligência Artificial, automação industrial, entre outros. (FRAGA et al., 2016).

Com isto, percebe-se que a operação logística está ligada à simplicidade de comunicação com o avanço dos meios tecnológicos, e possui relação direta com a evolução industrial.

Segundo Totvs (2021), o conceito de logística 4.0 engloba não somente o uso de computadores, mas também o de softwares, de ferramentas e aplicações em nuvem que podem proporcionar um melhor e maior controle de seus procedimentos, operando sob as diretrizes da Indústria 4.0, cuja utiliza a tecnologia para tornar a operação "smart", ou seja, inteligente; assim criando um sistema de produção mais coeso, eficiente, automatizado e com alta visibilidade.

\section{MEIO AMBIENTE: ÁGUA DE LASTRO E SEUS IMPACTOS}

Para as embarcações possuírem a estabilidade desejável em sua navegação e nas operações, evitando possíveis sinistros e avarias, é necessário o uso de um recurso hídrico tecnicamente conhecido como Água de Lastro. Esta nomenclatura provém do termo náutico "Lastro", que significa qualquer matéria pesada que se coloca no fundo de um navio para dar-lhe equilíbrio (Dicionário Online, 2021). Logo, usam-se tanques nos porões dos navios para armazenar a água recolhida em alto mar, para dar o peso e equilíbrio necessários ao calado; sendo esta despejada no mesmo intuito, quando o navio está atracado em um terminal e realizando operações de carga e/ou descarga. 
Segundo mencionado por Carmo (2006), o transporte marítimo de longo curso movimenta mais de $80 \%$ das mercadorias do mundo e junto a isto transfere internacionalmente cerca de 10 bilhões de toneladas de água de lastro ao ano.

Estima-se que deste montante, 40 milhões são descarregados anualmente no Brasil. Justamente por conta desta grande movimentação marítima e mundial, um fator a ser observado é que a água de lastro pode ser considerada como um dos principais transmissores de organismos nocivos para o meio ambiente costeiro, podendo contaminar as águas nativas com vírus, bactérias, algas e demais agentes biológicos invasores.

Por conta destas contaminações, pode desencadear o desequilíbrio ecológico, perda de biodiversidade, além dos prejuízos econômicos a quem utiliza destes recursos naturais; trazendo problemas igualmente preocupantes para a população, que possa vir a ser contaminada com alguma patologia referente a isso, conforme visto pela Agência Nacional de Transporte Aquaviário (ANTAQ, 2021). Observa-se então, que não há uma fiscalização adequada e rigorosa acerca da manutenção do lastreamento de navios, o que implica no não cumprimento das medidas indicadas pela Diretoria Colegiada da Agência Nacional de Vigilância Sanitária (ANVISA), 72/2009. Inclusive segundo dados da mesma com um estudo feito em 2001, revelou que em $71 \%$ das amostras de água de lastro de navios de cinco portos brasileiros tinham bactérias marinhas, entre elas, o vírus da cólera.

Uma forma de reverter futuras proliferações de doenças e danos nocivos ao meio ambiente, além do plano de contingência da Comissão de Meio Ambiente e Desenvolvimento Sustentável de 2008, seria um método conhecido como troca oceânica. Este método consiste, como o próprio nome diz, a realizar uma troca de águas de lastro em uma região consideravelmente segura. Os navios precisarão estar a uma distância de 200 milhas náuticas de preferência, antes de chegar ao seu destino, e os locais de troca deverão possuir pelo menos 200 metros de profundidade, com isso, a troca volumétrica da água de lastro deverá atingir uma eficiência de 95\%. Quanto mais longe da costa, menor é o risco de contaminação.

Segundo ANTAQ (2021), se usada de forma correta, a troca oceânica poderá reduzir consideravelmente o risco das bioinvasões, já que a substituição da água de lastro captada em regiões costeiras pela oceânica, seguindo parâmetros físico-químicos e biológicos permitem o descarte adequado. Ou seja, as espécies costeiras não conseguem sobreviver em ambientes oceânicos e vice-versa, por conta da alta salinidade.

Figura 1 - Despejo da água de lastro no costado do terminal

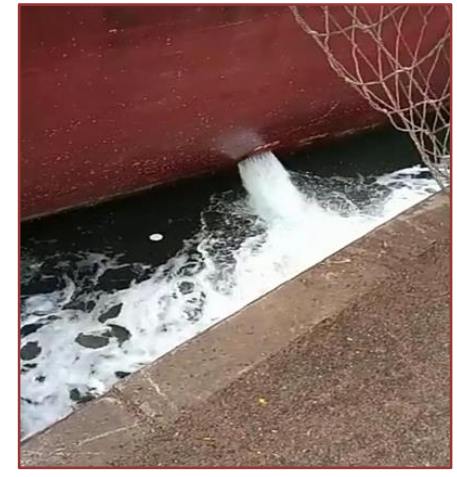

Fonte: Adaptado pelos Autores 


\section{PORTO VERDE, A VISÃO DO FUTURO SUSTENTÁVEL}

O Porto Verde, também conhecido como Green Port, é uma alternativa altamente viável para trazer meios sustentáveis ao nosso porto e com isso uma nova margem lucrativa, visando investimentos a longo prazo para este setor e utilizando a tecnologia como um auxílio complementar a este novo recurso, ainda pouco conhecido em nossa realidade.

Acerca disto, atualmente está em pauta na Santos Port Authority, a implementação de uma espécie de ranking para as embarcações menos poluentes, também conhecidos como os "Navios Verdes", além da eletrização dos terminais santistas, após a privatização do Porto.

Figura 2 - Porto com energia eólica

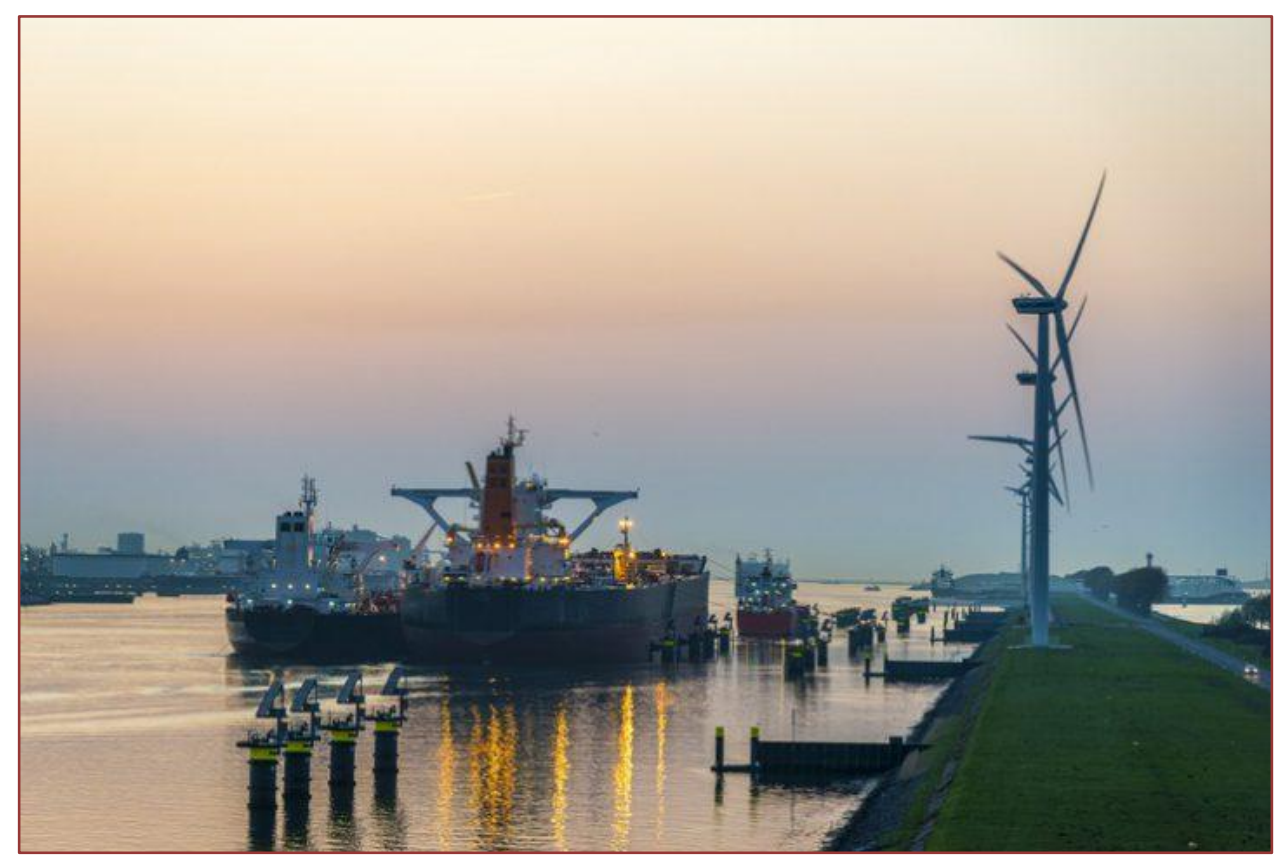

Fonte: Port Technoogy, 2021.

Segundo a Port Technology (2021), o porto verde é fruto de investimentos e operações ecologicamente corretas e por meios sustentáveis, incentivados em todo o ramo marítimo e nos diversos tipos de portos que são conhecidos. Apesar de as operações portuárias ser diferentes de acordo com a movimentação de cargas e a sua necessidade, existe uma forma menos poluente de fazê-lo, utilizando de tecnologias verdes, com uso de zero carbono para combustíveis fósseis e também para os equipamentos dos terminais, cujos necessitam de uma grande porção de energia.

Com base nisto, podemos mencionar uma das grandes empresas marítimas que visa esta inovação e está engajada a reduzir as emissões de carbono, um grande exemplo a ser seguido é a Maersk, que está investindo em tecnologia verde e pretende lançar em 2023 o seu primeiro navio sem carbono, utilizando o metanol. De acordo com o CEO, Søren Skou, a ambição do consórcio é liderar e abrir um novo caminho para a descarbonização da logística global, e tendo uma frota de carbono neutro, a meta idealizada a três anos atrás agora se tornou possível de ser atingida (PORTOS E NAVIOS, 2021). 
Analisando este dado bibliográfico mencionado pela Port Technology (2021), para que um porto possa ser sustentável, ele precisa usar energias renováveis, como a eólica, exemplificada acima na Figura 3. Por este fator a eletricidade no porto pode ser um grande adianto nas operações, considerando uma conexão dos navios atracados com a energia fornecida pelos terminais, pode amenizar o uso de geradores e reduzir o consumo de combustível da embarcação. Além disso, os equipamentos portuários também podem ser somente elétricos e sem emitir carbono, este modelo já é uma realidade nos RTG's do Porto de Long Beach, conforme ilustrado na figura 3.

Salientando a ideia de um porto ecologicamente correto, de acordo com o material fornecido este ano pelo site Porto e Navios (2021), Long Beach saiu na frente mais uma vez: o segundo maior porto dos Estados Unidos construiu seu mais novo terminal totalmente verde, em Middle Harbor. Desta vez, não apenas os RTG's, como todo o terminal em si é elétrico, possibilitando aos navios que atracam manter seus motores desligados, enquanto utilizam da energia do cais que o opera. Os equipamentos tem emissão zero, e foram projetados para melhorar o fluxo da carga e melhorar a qualidade do ar. Além disso, toda a estrutura foi expandida, tendo capacidade suficiente para operar três navios de grande porte ao mesmo tempo, e possui uma significativa economia de água e energia.

Figura 3 - RTG's elétricos do Porto de Long Beach

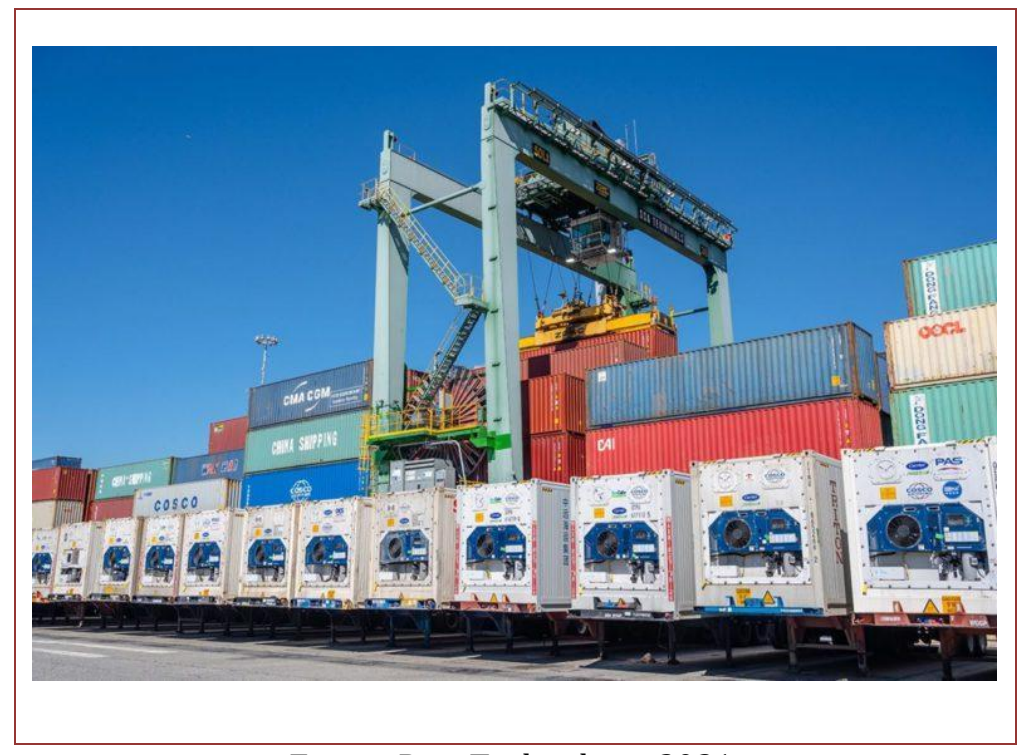

Fonte: Port Technology, 2021.

Estes pórticos mostrados acima são uma nova investida que visa futuramente ser cada vez mais comum nos terminais e ajudar a reduzir a emissão de CO2. Quanto aos combustíveis, a aposta da vez além do metanol mencionado anteriormente, também tem como exemplo os hidrogênios azuis, feito por combustíveis fósseis; e o verde, vindo da eletrólise renovável; o Gás Natural Liquefeito (GNL), amônia e biocombustíveis.

Tendo em vista os pontos citados, e fazendo um breve comparativo reportado pelo Jornal Portuário (2020), podemos mencionar alguns portos nacionais que atingiram o primeiro lugar na aplicação do Índice de Desenvolvimento Ambiental, divulgado pela Agência Nacional de Transporte Aquaviário (ANTAQ) em agosto do ano passado; destacam-se os portos catarinenses como o de Itajaí e o de Itapoá; o de Santos está em 
sétimo lugar deste ranking, conforme ilustrado na Figura 4, porém não foram mencionados nenhum tipo de energia renovável ou semelhante, estes apenas seguem o protocolo da Gerência de Meio Ambiente e Sustentabilidade (GMS), que faz a gestão ambiental dos portos.

Figura 4 - Ranking IDA 2020

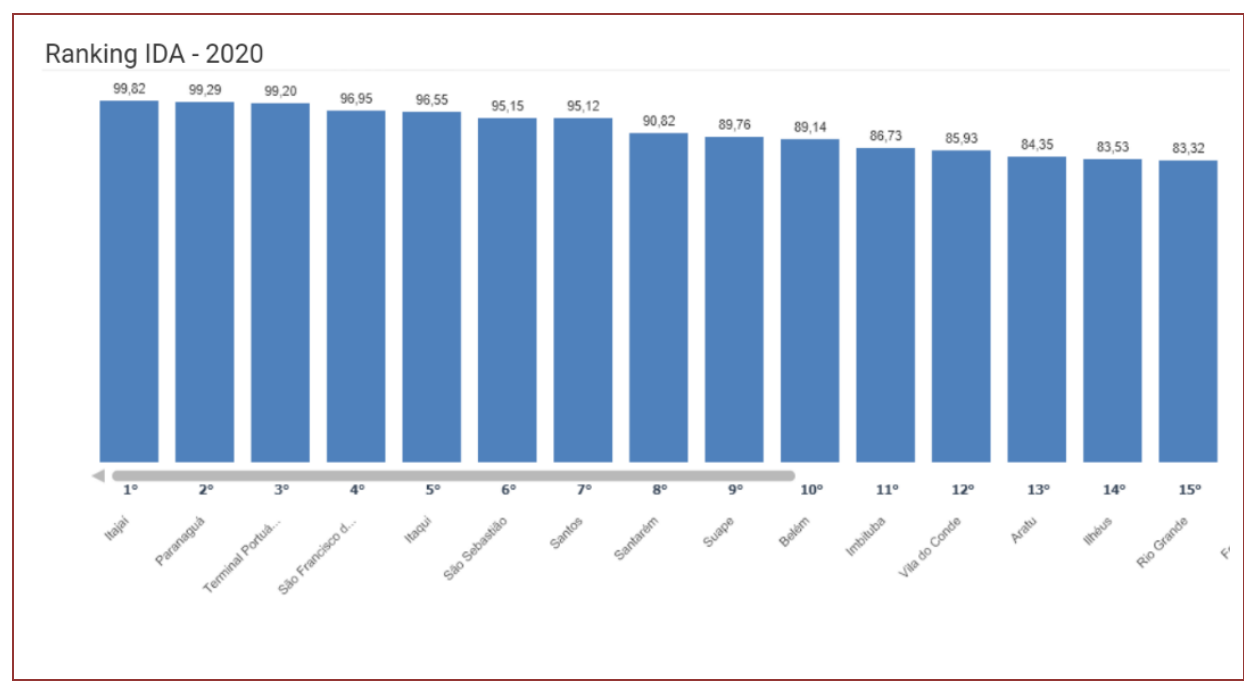

Fonte: ANTAQ (2021).

Sendo assim, vemos que este assunto deverá ser abordado e enfatizado mais vezes, pois para aplicar estes modelos renováveis em nossos terminais ainda há muito a ser feito, os portos brasileiros são desprovidos de operações totalmente sustentáveis e precisam cumprir exigências ecológicas, culturais, sociais, econômicas e institucionais, conforme salientado pela Portogente (2020).

\section{CONSIDERAÇÕES FINAIS}

Para que a tecnologia e a sustentabilidade sejam devidamente implantadas não somente no Porto de Santos, mas em todos os clusters portuários presentes em nosso país, as autoridades governamentais devem-se atentar a maiores investimentos nesta área, visando uma margem lucrativa interessante e a longo prazo, bem como incluir melhorias nas operações com seus modais, ampliar monitoramentos e dar descartes adequados aos resíduos trazidos das embarcações, dando mais segurança aos trabalhadores e o ambiente como um todo, além de trazer fontes renováveis de energia e consumo para os terminais e embarcações.

Percebe-se então, que há a possibilidade de fazer o nosso Porto crescer de forma exemplar, caso estes detalhes sejam devidamente ponderados, juntamente aos princípios sustentáveis para que possamos nos tornar exemplo mundial de renovação ecológica e ambiental, com plena sinergia. Vemos que, o investimento é alto, porém seu resultado pode vir ainda maior e com um índice mais satisfatório. 


\section{REFERÊNCIAS}

[1]. ANTAQ. Meio Ambiente - Água de Lastro. Disponível em:

http://web.antaq.gov.br/portalv3/MeioAmbiente_AguaDeLastro.asp\#: :text=0\%20uso\%20da

$\% 20 \%$ C3\%A1gua $\% 20$ de,casco\%20dentro\%20de\%20limites\%20seguros. Acesso em maio, 2021.

[2]. ANTAQ. Ranking IDA. Disponível em: http://web.antaq.gov.br/ResultadosIda_. Acesso em dezembro, 2021.

[3]. Carmo, Marcela Chauviere. Água de Lastro: um problema ambiental. Texto original disponível em:

https://www.researchgate.net/publication/318220215_Agua_de_lastro_um_problema_ambient al. Acesso em: maio, 2021.

[4]. FRAGA, M. A. F.; FREITAS, M. M. B. C.; SOUZA, G. P. L. Logística 4.0: Conceitos e aplicabilidade -uma pesquisa-ação em uma empresa de tecnologia para o mercado automobilístico. Disponível em:

<https://cadernopaic.fae.edu/cadernopaic/article/view/214/175>. Acesso em: maio de 2021.

[5]. Jornal Portuário. ANTAQ divulga ranking de desenvolvimento ambiental dos portos brasileiros. Disponível em: https://jornalportuario.com.br/interna/destaque-portuario/antaqdivulga-ranking-de-desenvolvimento-ambiental-dos-portos-brasileiros. Acesso em: Junho, 2021.

[6]. Log Comex. Tudo sobre portos automatizados. Disponível em:

https://blog.logcomex.com/portos-automatizados/. Acesso em: maio, 2021.

[7]. MAZZEO, Marco Aurélio Pires. A Importância da informação na logística: programação de peças pequenas por nível de estoque na Fiat. Dissertação (Mestrado em Engenharia de Produção e Sistemas) apresentada na Universidade Federal de Florianópolis/SC. 2001

[8]. Mais Polímeros. Logística Integrada, o que é sua aplicação e benefícios. Disponível em: http://www.maispolimeros.com.br/2019/09/19/logistica-integrada-o-que-e-sua-aplicacao-ebeneficios $/$. Acesso em dezembro, 2021.

[9]. Portogente. Como é aplicada a sustentabilidade na atividade portuária. Disponível em: https://portogente.com.br/portopedia/113700-como-e-aplicada-a-sustentabilidade-naatividade-portuaria. Acesso em maio, 2021.

[10]. Portogente. Indústria 4.0, o que esse mercado espera dos profissionais. Disponível em: https://portogente.com.br/portopedia/98506-industria-4-0-o-que-e-o-que-esse-mercadoespera-dos-profissionais. Acesso em: maio, 2021.

[11]. Portos e Navios. Maersk irá operar em 2023 o primeiro navio do mundo neutro em carbono. Disponível em: https://www.portosenavios.com.br/noticias/navegacao-emarinha/maersk-ira-operar-em-2023-o-primeiro-navio-de-linha-do-mundo-neutro-emcarbono. Acesso em junho, 2021.

[12]. Porto e Navios. Concluído o mega terminal totalmente elétrico e de emissões zero de Long Beach. Disponível em: https://www.portosenavios.com.br/noticias/portos-elogistica/concluido-o-mega-terminal-totalmente-eletrico-e-de-emissoes-zero-de-long-beach. Acesso em dezembro, 2021.

[13]. Port Technology. What is Green Port? traduzido. Texto original e imagens disponível em: https://www.porttechnology.org/news/what-is-a-green-port/. Acesso em: maio, 2021.

[14]. VDI Brasil. Relação entre Indústria 4.0 e sustentabilidade. Disponível em: https://rmai.com.br/a-relacao-entre-industria-4-0-e-sustentabilidade/. Acesso em: maio, 2021. 


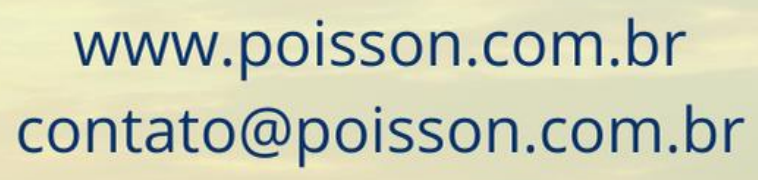

@editorapoisson

https://www.facebook.com/editorapoisson

(0) 